Mário Henrique de Castro Caldeira

\title{
Arquitetura para educação: escolas públicas na cidade de São Paulo (1934-1962)
}

Tese apresentada à Faculdade de Arquitetura e Urbanismo da Universidade de São Paulo para obtenção do título de Doutor em Arquitetura e Urbanismo

Área de Concentração: Estruturas Ambientais Urbanas

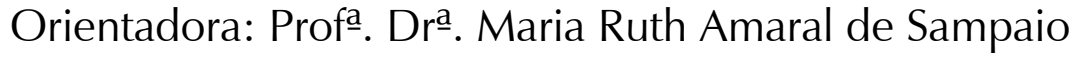


Mário Henrique de Castro Caldeira

Arquitetura para educação:

escolas públicas na cidade de São Paulo (1934-1962)

Tese apresentada à Faculdade de Arquitetura e Urbanismo da Universidade de São Paulo para obtenção do título de Doutor

Área de Concentração: Estruturas Ambientais Urbanas

Aprovação:

Banca examinadora

Prof. Dr.

Instituição: Assinatura:

Prof. Dr.

Instituição: Assinatura:

Prof. Dr.

Instituição: Assinatura:

Prof. Dr.

Instituição: Assinatura:

Prof. Dr.

Instituição: Assinatura: 
A meu pai, José de Ribamar (in memoriam)

À minha mãe, Marlene 


\section{Agradecimentos}

Um trabalho deste porte jamais poderia ser feito sem o auxílio direto e indireto de inúmeras pessoas, ainda que em determinados momentos seja muito solitário redigir uma tese. O apoio da minha orientadora profa. Maria Ruth do Amaral Sampaio foi fundamental em todos os momentos. Sua leitura atenta e críticas corretas contribuíram para direcionar o trabalho e torná-lo mais objetivo. A contribuição também essencial durante o processo de qualificação deve ser ressaltada: a leitura criteriosa, durante o processo de qualificação desta tese, feita pelos professores e arquitetos Dr. Carlos Ferreira Martins e Dr. Júlio Roberto Katinsky deram fôlego novo às minhas investigações. Ao prof. Dr. Celso Lamparelli, pela sua visão clara e narrativa espantosamente articulada e precisa dos fatos.

Um agradecimento com ar de reverência deve ser feito aos professores e arquitetos Eduardo Corona (in memoriam), Roberto Goulart Tibau (in memoriam), Ernesto Roberto Carvalho Mange (in memoriam) e Aluísio Rocha Fernandes Leão, que trabalharam diretamente na Comissão Executiva do segundo Convênio Escolar da cidade de São Paulo. Este trabalho também pretende ser uma singela homenagem a eles e à sua dedicação à arquitetura.

Agradeço à direção e aos funcionários da Secretaria de Edificações da Prefeitura do Município de São Paulo (EDIF-PMSP), que me permitiram ter acesso ao seu arquivo, e em especial ao sr. Rui que tão atenciosamente me indicou como descobrir verdadeiros preciosidades naquele labiríntico e fantástico acervo. Aos funcionários da minha estimada FAU-USP, em especial aos da biblioteca e a sempre prestativa funcionária do Laboratório de Fundamentos da Arquitetura e Urbanismo da FAUUSP, Iliete Maria Franco de Arruda, sempre solícita e atenciosa.

Um agradecimento especial vai para as coordenadoras do Curso de Arquitetura e Urbanismo da Universidade Paulista, Sandra Regina da Silva Duarte e Silvana D. V. Iizuka, e para as funcionárias do Núcleo de Apoio Arquitetura e Urbanismo daquela universidade, Ana Maria de Oliveira e Vanessa Cristine dos Santos, pelo precioso apoio institucional e cessão das instalações do curso para a conclusão desta tese.

Agradeço profundamente ao historiador Dr. João Ricardo de Castro Caldeira, a Luzia Lavanholi Guaraldo e, em especial, à arquiteta $\mathrm{Dr}^{\mathrm{a}}$. Eliane Guaraldo, pela leitura e revisão criteriosa do texto, bem como pela sua contribuição quanto à organização interna desta tese. As contribuições do arquiteto Ms. Sérgio Augusto Menezes Hespanha e da arquiteta Ms. Ana Elena Salvi vieram de ricas e acaloradas discussões sobre o conteúdo deste trabalho.

À minha esposa Rosemeire, que me direcionou nos meandros das teorias e conceitos da pedagogia, sempre com carinho e dedicação.

A todos, o meu muito obrigado. 


\title{
Resumo
}

Este trabalho tem como objeto de estudo a arquitetura das escolas públicas, construídas na cidade de São Paulo, entre 1934 e 1962, a qual é analisada de duas maneiras distintas: uma geral e uma específica.

A análise geral identificou uma maneira de projetar que impregna todos os projetos, com exceção dos últimos, do período escolhido. Nesse sentido, a arquitetura daquelas escolas teve como uma das referências principais os conhecimentos técnicos, científicos e pedagógicos como base fundamental para a definição dos seus espaços internos e para sua organização volumétrica. Ao final da década de 1950 e início da década de 1960 desaparecem totalmente os referenciais científicos e parte dos referenciais técnicos, restando os referenciais pedagógicos e construtivos.

A análise específica permitiu identificar cinco tipos de soluções arquitetônicas: a concepção por extrusão (1934-1947), a composição aditiva de volumes especializados (19481958), a concepção de um volume gerado pela seqüência de pórticos aparentes em concreto armado (1959-1961), a concepção por sobreposição de planos estruturais e planos de vedação (1962) e as soluções emergenciais, que foram as escolas sem arquitetura e as construções temporárias (1954-1959). Essa classificação ao longo da história da arquitetura de escolas públicas na cidade possibilitou visualizar os elos que elas possuem em comum, até o final da década de 1950. Nesse momento, encerrando a periodização histórica adotada, ocorre uma série de mudanças na maneira pela qual o poder público (Estado e Município) exerce sua capacidade de ampliar a rede física da educação pública na cidade, contribuindo para a alternância de concepções arquitetônicas para os projetos de escolas.

Palavras chave Educação. Arquitetura. Escola. História.

\begin{abstract}
This work focuses on the architecture of public educational facilities, builded in Sao Paulo, from 1934 to 1962. It analyzes the design of those buildings: the concept design of schools in 1930's until 1950's was a scientific and technical based one. However, this design will turn onto a plastic based one, in the 1960's. The history of those buildings begins with the Art Deco's style, in the 1930's and 1940's, it goes through the modernism brought by the architects that came from Rio de Janeiro in 1950's, and ends towards a new architecture, developed at in 1960's.
\end{abstract}

Keywords

Educational facilities. Architecture. History. 


\section{Lista de Abreviações}

Esta lista tem por intuito facilitar a leitura em face das várias instituições e atividades relacionadas neste trabalho, e das muitas vezes em que o seu nome é citado. Procurou-se utilizar abreviações e acrônimos de uso corrente sempre que possível. Quando não era o caso, adotou-se nesta tese uma abreviação das primeiras letras contidas no nome ou um nome simplificado.

$\mathrm{CE}$

Convênio Escolar

DOP

EDIF

FAUUSP

FECE

G.E.

IPESP

Politécnica

SAGMACS

PMSP
Comissão Executiva do segundo Convênio Escolar

Convênio entre Governo do Estado de São Paulo e Prefeitura do Município de São Paulo para a construção e funcionamento de escolas

Departamento de Obras Públicas do Estado de São Paulo. Anteriormente era denominado Diretoria de Obras Públicas, e estava subordinado à Secretaria de Viação e Obras. Também designa Departamento de Obras Públicas da Prefeitura do Município de São Paulo.

Secretaria de Edificações do Município de São Paulo

Faculdade de Arquitetura e Urbanismo da Universidade de São Paulo

Fundo Estadual de Construções Escolares

Grupo Escolar

Instituto de Previdência do Estado de São Paulo

Escola Politécnica da Universidade de São Paulo

Sociedade de Análise Gráfica e Mecanográfica Aplicada aos

Complexos Sociais

Prefeitura do Município de São Paulo 


\section{Introdução}

1.1 O objeto de estudo

1.2 Transformações na arquitetura das escolas públicas: influências e propósitos

2. A modernização do ensino e da arquitetura escolar: 1934-1947 21

2.1. As iniciativas públicas

2.2. A fonte teórica: as propostas de Anísio Teixeira e Fernando de Azevedo

2.3. O planejamento da rede física escolar na década de 1930

2.4. Ciência e Arquitetura: o Art Déco a serviço da educação

2.5. Legislação, educação e arquitetura

2.6. Os projetos na década de 1930: concepção por extrusão 38

2.7. O modelo de escola e a modernidade oficial 41

2.8. Um período obscuro $\quad 46$

3. A ampliação da rede física escolar do município: 1943 a 1954

3.1. O primeiro Convênio Escolar 54

3.2. A Comissão Executiva do segundo Convênio Escolar 57

3.3. As escolas da década de 1950: composição aditiva e as técnicas construtivas 62

3.4. A implantação e o vazio $\quad 64$

3.5. A sistematização dos projetos: produção em série 65

\begin{tabular}{lll}
\hline 3.6. & Arquitetura e indústria & 66 \\
\hline 3.7. & A autonomia da Comissoo Executiva e o planejamento escolar
\end{tabular}

\begin{tabular}{lll}
\hline 3.7. A autonomia da Comissão Executiva e o planejamento escolar & 74 \\
\hline 3.8. & Os sistemas
\end{tabular}

\begin{tabular}{lll}
\hline 3.8. & Os sistemas construtivos & 76
\end{tabular}

\begin{tabular}{lll}
\hline 3.9. & As escolas da Comissão Executiva & 78
\end{tabular}

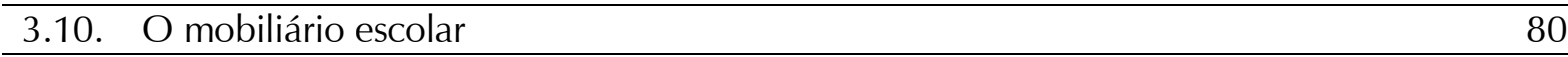

3.11. Arquitetura, técnica e ciência 23

\begin{tabular}{lr}
\hline 4. Novos rumos para a arquitetura escolar & 90
\end{tabular}

\begin{tabular}{lll}
\hline 4.1. & O fim do segundo Convênio Escolar & 91
\end{tabular}

\begin{tabular}{lll}
\hline 4.2. & A situação da rede física escolar mostrada pela pesquisa SAGMACS & 93 \\
\hline
\end{tabular}

\begin{tabular}{lll}
\hline 4.3. & O planejamento escolar & 95
\end{tabular}

\begin{tabular}{lll}
\hline 4.4. & As escolas sem arquitetura e a rede municipal de ensino & 96
\end{tabular}

\begin{tabular}{lll}
\hline 4.5. & O início da pesquisa SAGMACS e a rede escolar & 98
\end{tabular}

\begin{tabular}{llr}
\hline 4.6. & A leitura de projetos do exterior & 99
\end{tabular}

\begin{tabular}{lll}
\hline 4.7. & Os galpões de madeira & 102 \\
\hline 4.8. & As escolas da Comissăo de Constuçôs Escolares
\end{tabular}

\begin{tabular}{lll}
\hline 4.8. & As escolas da Comissão de Construções Escolares & 103
\end{tabular}

\begin{tabular}{lll}
\hline 4.9 & A separação entre Prefeitura e Estado: a iniciativa municipal & 109
\end{tabular}

\begin{tabular}{lll}
\hline 4.10. & O Plano de Ação do Governo do Estado e os escritórios de arquitetura & 111 \\
\hline
\end{tabular}

4.11. O Fundo Estadual de Construções Escolares e o Instituto de Previdência do Estado 112 de São Paulo

4.12. Os novos caminhos da arquitetura escolar 116

4.13. A introdução de novos referenciais no projeto de escolas 121

5. Considerações finais

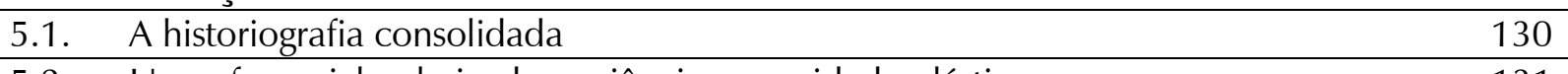

5.2. Um referencial polarizado: a ciência e a unidade plástica 131 


\begin{tabular}{lr}
\hline Referências bibliográficas & 136 \\
\hline Periódicos e arquivo & 140 \\
\hline Anexo A - Depoimentos & 143 \\
\hline Roberto Goulart Tibau & 144 \\
\hline Ernesto Roberto Carvalho Mange & 152 \\
\hline Eduardo Corona & 158 \\
\hline Celso Lamparelli & 168 \\
\hline Anexo B - Projetos de escolas públicas & 172 \\
\hline Projetos realizados entre 1934 e 1948 & 174 \\
\hline Projetos realizados entre 1949 e 1958 & 182 \\
\hline
\end{tabular}


Introdução 
Este trabalho tem como objeto de estudo as arquiteturas das escolas públicas construídas entre 1934 e 1962, na cidade de São Paulo, analisadas a partir das premissas que direcionaram as suas diferentes manifestações ao longo do tempo. Procurou-se configurar uma história capaz de explicar as profundas transformações ocorridas nesse programa arquitetônico. A abordagem utilizada para desenvolver essa narrativa crítica, foi criar dois tipos de análise: uma geral e uma específica. Essa separação torna-se necessária pela multiplicidade de questões e agentes envolvidos na realização de projetos arquitetônicos, e mais ainda, no caso presente, por se tratar de obras construídas em grande quantidade e de finalidade pública.

A análise geral identificou uma maneira de projetar que impregna a maioria dos projetos de escolas públicas identificados pela pesquisa, dentro do período escolhido. Nesse sentido, pode-se afirmar que a arquitetura daquelas escolas teve como uma de suas referências fundamentais os conhecimentos técnicos, científicos e pedagógicos para a definição dos seus espaços internos e para sua organização volumétrica. Ao final da década de 1950 e início da década de 1960, no entanto, desaparecem totalmente os referenciais científicos e parte dos referenciais técnicos, restando os referenciais pedagógicos e as técnicas construtivas.

A análise específica, por seu lado, permitiu identificar cinco tipos de soluções arquitetônicas: a concepção por extrusão (1934-1947), a composição aditiva de volumes especializados (1948-1958), a concepção de um volume gerado pela seqüência de pórticos aparentes em concreto armado (1959-1961), a concepção por sobreposição de planos estruturais e planos de vedação (1962) e as soluções emergenciais, que foram as escolas sem arquitetura e as construções temporárias (1954-1959).

Essa classificação, construída ao longo da história da arquitetura de escolas públicas na cidade possibilitou separar arquiteturas que, de um lado, possuíam um referencial teórico em comum, porém com resultados plásticos e composições diferentes entre si. 
No final da década de 1950 e início da década de 1960, encerrando a periodização histórica adotada, ocorre uma série de mudanças na maneira pela qual o poder público (Estado e Município) exerce sua capacidade de ampliar a rede física da educação pública na cidade, contribuindo para a alternância de concepções arquitetônicas para os projetos de escolas.

A presença do programa escolar, como meio de gerar construções especificamente projetadas para esse fim, dentro das análises históricas feitas sobre a arquitetura no século XX é bastante limitado, se comparado a outros programas. Ao traçar as historiografias do estabelecimento e desenvolvimento da arquitetura moderna no Brasil, a grande maioria dos principais textos sobre o assunto privilegiou dois programas: o da habitação, individual e coletiva, e o da indústria e de edifícios voltados para os seus produtos (palácios de exposições). Essa vertente que ocorre também no mundo ocidental não é apenas uma seleção estabelecida por critérios historiográficos, pois foi nesses programas que os principais arquitetos e engenheiros estabeleceram as linhas mestras da arquitetura moderna, a partir do século XIX, estendendo-se com intensidade, ainda nesses dois programas, pelo século XX.

Os demais programas também comparecem, mas nitidamente ficam em segundo plano, pois foi, de fato, com o desenvolvimento do edifício industrial e da habitação urbana que se conformaram as conquistas técnicas e espaciais da arquitetura no século XX, e junto a isso o discurso fundamentador da ideologia da arquitetura moderna: a relação entre espaço e sociedade, e ao mesmo tempo, a possibilidade da arquitetura intervir no meio em que ela é realizada. Essa concepção irá alcançar profundamente o programa da escola pública.

Entre outros programas importantes para o estabelecimento e desenvolvimento da arquitetura moderna, estão os edifícios institucionais voltados para a organização da sociedade (palácios governamentais, sedes de órgãos internacionais multilaterais, sedes de empresas privadas), edifícios voltados para o transporte (gares ferroviárias), obras-de-arte da engenharia (pontes, viadutos). 
O programa do edifício escolar, ao contrário dos que foram citados e das exceções, que também existiram, somente começa a comparecer dentro do universo de projeto dos arquitetos, que no início do século XX definiam e implantavam, na medida do possível, o ideário plástico e ideológico da arquitetura moderna no Ocidente, a partir de década de 1920. Em São Paulo, mais especificamente, essa inserção do programa do edifício escolar somente ocorre a partir da década de 1930.

Os edifícios voltados para o ensino de adultos aparecem como palco de algumas das principais conquistas da arquitetura moderna, como o edifício da Bauhaus (1925), em Dessau, na Alemanha, projetado por Walter Gropius, e a escola de Arte de Glasgow (1896-1909), na Inglaterra, projeto de Charles Rennie Macintosh.

Apesar do início tardio no Brasil, como programa a ser enfrentado com critérios modernos, o edifício escolar rapidamente assumiu uma posição de destaque. Por edifício escolar definimos aquelas construções voltadas para o ensino denominado de primário e colegial, os quais correspondem, atualmente, ao ensino fundamental I e II, e ensino médio, ou seja, educação para crianças e adolescentes.

Este trabalho pretende ser uma contribuição para a inserção do programa do edifício escolar na trajetória da arquitetura moderna em São Paulo, sem relegar ao segundo plano as especificidades da escola. Nesse sentido será possível avaliar a intensa produção a que se chegou durante o período analisado e ao formidável trabalho desenvolvido por profissionais que acreditavam em uma causa, a da educação como meio de transformar a sociedade. As escolas que constituem o escopo desta pesquisa estão concentradas na cidade de São Paulo, configurando o objeto na sua parte material. Dessa parte material foi analisada a arquitetura e os meios utilizados para desenvolvê-la. Assim, procurou-se evitar privilegiar essa ou aquela aparência final da edificação, mas sim discutir suas relações espaciais internas, programas, propostas pedagógicas e sua relação com o espaço construído, critérios de projeto e resultados alcançados. Também se procurou evitar assumir como referência de análise dentro desta 
pesquisa a ideologia que se tornou corrente no meio que gerou essas construções: a de que a arquitetura é efetivamente um meio de transformar a sociedade, e principalmente na escola teria sua capacidade transformadora amplificada. Essa visão necessariamente comparece no texto por se tratar de uma forma bastante disseminada de pensar um sentido para a arquitetura, ou seja, os arquitetos que atuavam nesses projetos tinham essa perspectiva em mente.

\subsection{O objeto de estudo}

As décadas de 1930, 1940 e 1950 podem ser consideradas como o período de introdução, consolidação e, por fim, transformação da arquitetura moderna nas escolas públicas realizadas pelo governo do estado de São Paulo e pela prefeitura da capital paulista, na cidade de São Paulo.

A periodização abrange um corpo de projetos de escola caracterizados pelos seguintes temas:

a) é a partir de 1934 que se introduz um conhecimento técnico e científico na definição dos espaços do edifício e de sua organização interna, e é no final da década de 1950 e início de 1960, que a aplicação desse conhecimento desaparece dos projetos de escolas públicas;

b) o período analisado contém a introdução de novas técnicas construtivas, principalmente relacionadas ao uso do concreto armado;

c) os projetos feitos entre 1934 e 1962 serão os palcos para o exercício de um novo conjunto de propostas pedagógicas, nas quais o espaço passa a ser considerado parte integrante do processo de educação;

Dessa maneira definiu-se a periodização adotada, procurando estabelecer criteriosamente o período escolhido. Dentro dessa periodização foi feito um levantamento exaustivo de um dos principais arquivos públicos da cidade de São Paulo, que pertence à Secretaria de Edificações (EDIF) da Prefeitura do Município de São Paulo (PMSP). Nesse levantamento procurou-se a maior quantidade possível de informações, além dos desenhos 
dos projetos, e sempre que possível buscou-se complementar a pesquisa com outras fontes. $\mathrm{Na}$ medida em que as informações estão disponíveis elas foram inseridas no trabalho, como, por exemplo, o nome das construtoras responsáveis pelos projetos.

Com o período da pesquisa definido, é necessário ainda destacar que dentro da aparente unidade dos conceitos presentes na arquitetura daquelas escolas, acima citados, há, internamente, uma clara divisão da maneira que os arquitetos, em cada momento, escolhiam para definir o desenho final dos edifícios.

O item 2 contém os projetos que podem ser classificados, do ponto de vista de seu desenho final e de sua aparência exterior, como uma arquitetura Art Déco. Esse primeiro momento traz profundas transformações na forma de organizar os espaços de um edifício com fins educacionais, pois vários profissionais introduzem conceitos baseados em aspectos científicos para justificar as decisões tomadas nos projetos. Os espaços internos passam a ser agrupados seguindo uma nova pedagogia e as plantas abandonam sua rígida simetria exclusivamente formal, como eram as escolas até então, e expandem-se em outras direções. A simetria horizontal é substituída, em parte, por uma organização espacial vinculada à insolação e a aspectos pedagógicos. Apesar disso, foram encontrados projetos que têm um nítido vínculo com outras arquiteturas, indo desde um ecletismo simplista e nostálgico até uma arquitetura clássica racionalista, semelhante à que fora feita por Marcello Piacentini ${ }^{1}$. Esse momento se inicia em 1934 e culmina em 1947, abrangendo, portanto, todo o período em que se consolidam os dogmas arquitetônicos da modernidade, e que alcançam, não de forma plena, os projetos de escola na capital paulista.

O item 3 trata das escolas projetadas entre 1943 e 1954. A sobreposição de datas dos capítulos ocorre devido ao critério de seleção dos projetos, o qual está amparado em uma certa independência que cada arquitetura aplicada nos projetos de escolas possui internamente. 1943 é o ano em que se Estado e Município assinam o primeiro Convênio

\footnotetext{
${ }^{1}$ Cf. FRAMPTON, 1998, p. 248.
} 
Escolar, estimulados por uma decisão federal. É a partir dos Convênios entre as duas esferas de poder que irá ocorrer um novo surto de construções escolares na cidade de São Paulo. Durante o primeiro Convênio o governo do Estado continua, através da Diretoria de Obras Públicas (DOP), a construir escolas na capital, as quais estão incluídas no capítulo anterior. É nesse período que se encerra o primeiro Convênio Escolar, com poucos resultados na construção de escolas, e se inicia em 1948 um novo Convênio Escolar. É através da Comissão Executiva criada para executar as premissas desse Convênio, que é introduzido no programa escolar da capital, definitivamente, a arquitetura moderna. Há ainda semelhanças com o período anterior, que são de um lado, o uso de propostas arquitetônicas baseadas em determinações de base científica e técnica, como conforto térmico e acústico, insolação, organização espacial interna, e de outro lado, a aplicação de propostas pedagógicas inovadoras tal como fora feito antes de 1940. Porém as semelhanças terminam aí, pois o repertório formal moderno impõe-se. Esse repertório, trazido por arquitetos formados no Rio de Janeiro, é de influência especificamente francesa, e possivelmente também resultado de estudos sobre experiências espanholas e americanas na área da educação. Os espaços internos, organizados por funções bastante específicas, refletem o conceito orgânico de agrupar usos semelhantes e de expor, externamente qual a função que ocorre no seu interior.

Surge então um conjunto de propostas novas em relação à cidade: o vínculo com uma intenção de intervenção urbana e com o planejamento urbano. Essas propostas de intervenção e as fórmulas de planejamento urbano não se materializaram, revelando uma profunda distância entre as propostas urbanas dos arquitetos e engenheiros responsáveis pelos projetos e a cidade na qual eram implantadas as edificações voltadas para a educação.

O item 3 inicia em 1954, com o encerramento do Convênio Escolar entre Estado e Município, e conclui em 1962. Nesse período, ocorre a continuidade das atividades iniciadas durante a vigência do segundo Convênio Escolar, agora sob o nome de Comissão de Construções Escolares, com a expansão da rede física de educação tanto por parte do 
município quanto por parte do governo do Estado de São Paulo. É um momento de continuidade e de transição, em que a maneira de construir edifícios para a educação será profundamente questionado. São implantados projetos de escolas "temporárias", feitas de madeira, em regime de urgência para atender à crescente demanda de salas de aula. Cria-se o sistema das escolas sem arquitetura, no qual está a origem do sistema de ensino exclusivamente municipal.

A comissão de Construções Escolares mantém suas atividades com uma arquitetura bastante semelhante à que foi implantada pelos arquitetos participantes da CE. Nesses anos acentua-se o conflito entre a necessidade de espaços dedicados exclusivamente à educação, e a incapacidade do governo de atender plenamente a essa demanda.

O próximo momento da escola pública em São Paulo traz uma mudança interna na arquitetura praticada pelo poder público, e que traria conseqüências profundas. Trata-se da introdução de uma nova forma de contratar os profissionais, que se tornariam os responsáveis pela realização dos projetos de escolas públicas, contratados pelo governo do Estado de São Paulo. Essas transformações alcançariam mais tarde o poder municipal. A participação desses profissionais trouxe outros critérios e formas que seriam adotadas na arquitetura das escolas. A própria Comissão de Construções Escolares também começa a modificar a arquitetura que praticara até então. Nesse caso, porém, serão os mesmos arquitetos que já atuavam desde anos anteriores dentro do setor público municipal, que começam a modificar sua maneira de fazer escolas.

Pela primeira vez, o programa escolar será um dos pontos de inflexão da arquitetura feita em São Paulo e servirá de referência para outros programas arquitetônicos. A contribuição de João Batista Vilanova Artigas, Carlos Cascaldi, Rubens Azevedo e Roberto Goulart Tibau é relevante. Entre as inovações introduzidas está o uso do sistema construtivo mais especificamente da estrutura tectônica - como definidora da própria arquitetura, o uso de uma simetria horizontal - referência que pode ser encontrada nas propostas do arquiteto 
alemão Mies van der Rohe -, bem como uma forma de organizar os espaços internos das escolas com uma unidade plástica definida por um único volume e não mais por uma composição aditiva. Porém, desaparece uma das principais características que estava presente em muitos dos edifícios escolares projetados até então: a partir de 1959, as razões que definiam as decisões arquitetônicas, baseadas principalmente em dados científicos e técnicos, e certas soluções arquitetônicas delas decorrentes, são substituídas por critérios vinculados à pedagogia, à organização volumétrica dos espaços internos e a aplicação de sistemas construtivos determinantes da arquitetura no projeto.

A divisão do período em três partes ainda não é suficiente para permitir uma compreensão maior do alcance das transformações que ocorreram na arquitetura escolar pública em São Paulo. Essas transformações na arquitetura também vieram acompanhadas, inevitavelmente do uso, por parte dos arquitetos, das técnicas construtivas disponíveis, baseadas no concreto armado e nas suas novas possibilidades, que se expandiam ao longo do período analisado. Esse conjunto de soluções técnicas, a partir da década de 1930, possibilitaria a realização de novas formas de implantação dos edifícios escolares, em íntima relação com as propostas pedagógicas que se procurava implantar na época. Posteriormente, o concreto armado seria introduzido com mais vigor nos projetos de escolas, culminando com propostas mais amplas de industrialização da construção e do projeto de escolas. Ao mesmo tempo, técnicas que utilizavam a madeira também não deixavam de ser utilizadas em larga escala.

Apesar da diferenciação explicitada que divide o período escolhido em três partes distintas tornou-se visível um aspecto similar em todos eles: as escolas projetadas no período têm em comum uma perspectiva proposta pelos arquitetos e educadores, que consistia em que a arquitetura, por si, viesse a ser um elemento determinante na educação de seus usuários. Ou seja, o edifício e espaços livres teriam papel fundamental no processo educacional. Mais do que isso, a partir da década de 1950, há o pressuposto, por parte de arquitetos e pesquisadores 
da época, de que os edifícios escolares e outros programas diversos a eles anexados (bibliotecas, auditórios) seriam os locais mais adequados para promover também a educação do cidadão adulto, congregar a comunidade na qual está inserida a escola e gerar transformações sociais.

\subsection{Transformações na arquitetura das escolas públicas: influências e propósitos}

O período de produção de escolas públicas na cidade de São Paulo que, dentro da perspectiva deste trabalho se inicia em 1934 e vai até 1962, encerra em si o processo de introdução e aperfeiçoamento da arquitetura moderna em edifícios escolares. E foi a arquitetura que gerou aqueles espaços, muitos deles usados até hoje, a representante mais direta dos interesses públicos que produziram edifícios escolares ao longo de todos esses anos.

A construção de escolas públicas ocorre sempre a partir do onipresente Estado, até a realização do Plano de $A c ̧ a ̃ o^{2}$, na década de 1960, quando os meios de produção dos projetos arquitetônicos são retirados do interior dos órgãos governamentais e é criado um órgão específico para tratar das construções escolares em todos os seus aspectos, o FECE.

Os projetos e períodos indicados revelam tanto o irregular interesse do poder público em solucionar o problema da formação dos cidadãos, quanto às perspectivas da educação que impregnam os espaços idealizados pelos engenheiros e arquitetos envolvidos. Deve-se ressaltar que o volume de escolas produzidas nesse período, em nenhum momento, consegue efetivamente atender à crescente demanda por vagas.

Esse período é marcado por três principais momentos na construção de escolas e programas vinculados à educação pública. O primeiro ocorre entre 1934 a 1937, quando há a

\footnotetext{
${ }^{2}$ Na cidade do Rio de Janeiro houve também um plano de intervenção emergencial na educação pública, organizado pelo governador do Estado da Guanabara, Carlos Lacerda. Para essa tarefa foi indicado o professor Flexa Ribeiro e o alcance das medidas adotadas é bastante semelhante, no que se refere à educação, aos interesses contidos no PLADI paulista. No Rio, a expectativa era de entrar no ano de 1962 (Carlos Lacerda assumiu em 1961) sem nenhum problema de vaga para as crianças no ensino público da cidade. $\mathrm{Cf}$. CAVALCANTI (2001).
} 
introdução de critérios modernos nos projetos de edifícios escolares, em contraposição à arquitetura que se realizava até 1930. A idéia de modernidade transparece nos conceitos eminentemente técnicos que conformam os espaços e dimensões das escolas. As formas adotadas remetem nitidamente ao Art Déco, tal como ele ocorreu em inúmeros outros edifícios da cidade de São Paulo. O segundo momento ocorre entre 1949 a 1954, quando o segundo Convênio Escolar realiza uma grande quantidade de projetos de escolas, incluindo bibliotecas, parques infantis, entre outros programas complementares. Estes projetos eram amplamente influenciados pela arquitetura moderna que desenvolvida no Rio de Janeiro, nas décadas de 1930 e 1940. Entre 1943 e 1948 foi realizado um primeiro Convênio Escolar, o qual construiu poucas escolas, por razões administrativas, mas possivelmente políticas também. Temos então o terceiro momento, de 1959 a 1962, quando, sob os auspícios do Plano de Ação, no governo estadual na administração Carvalho Pinto, são realizados projetos de escolas que encerram em si uma nova forma de resolver o problema da arquitetura escolar, sendo estas soluções amplamente divulgadas entre os arquitetos que trabalhavam em São Paulo.

No período situado entre 1954 e 1958 houve um aumento considerável no volume de obras realizadas, porém com qualidade bastante reduzida. As construções escolares resumiam-se a barracões de madeira, de pouca durabilidade, realizados dentro de uma perspectiva de economia de recursos e velocidade na criação de vagas escolares. Além de escolas também foram construídos diversos outros tipos de estabelecimentos ligados à educação e ao lazer público. Essa perspectiva de economia de recursos aparece continuamente ao longo do período analisado, e influencia os projetos das escolas. Nessa mesma época, a Prefeitura de São Paulo, enfrentando um crescimento vertiginoso da população da cidade, e sem condições de acondicionar em prédios novos o número de crianças que crescia a cada ano, propõe uma solução alternativa, porém precária. Cada professora que conseguisse reunir 
um certo número de alunos, para lecionar-lhes dentro de uma sala ou outro ambiente qualquer, seria contratada como professora do município.

Os períodos indicados representam saltos qualitativos dentro do processo de formação das instalações públicas voltadas para a educação. Considera-se assim que cada um daqueles três momentos expõe a obrigação definida por lei para o governo estadual e municipal enfrentarem o problema da formação do cidadão e sobre qual seria a educação mais adequada para as crianças e jovens. A arquitetura, nestes casos, reflete visivelmente a mudança de perspectivas em relação à educação que deveria estar presente no planejamento daqueles espaços. Por isto, sugere-se que, embora estes três momentos estejam distantes entre si no tempo, e com perspectivas teóricas e técnicas distintas, todos fazem parte de um único processo que envolve Estado, Educação e a arquitetura moderna em São Paulo. 
A modernização do ensino e da arquitetura escolar:

1934-1947 


\subsection{As iniciativas públicas}

As escolas produzidas em São Paulo entre 1934 e 1962 são conseqüências de iniciativas do Estado e do Município, ora trabalhando em conjunto, ora desenvolvendo suas próprias políticas educacionais. Essas iniciativas não eram sempre estanques, pois era comum a participação em conjunto de ambas as instâncias de poder público executivo para a realização de construções escolares, através de acordos, convênios e leis específicas, que definiam os atributos de cada um para satisfazer a necessidade ditada pela política e pelas diretrizes adotadas pelos governos. Porém, a necessidade política não é a única explicação para o impulso que levou uma parte da sociedade na época a assumir que deveria intervir na incipiente precária educação pública universal e gratuita. Há uma série de agentes extremamente atuantes, como educadores, arquitetos, políticos e artistas, envolvidos na transformação da escola pública durante a década de 1920 e 1930. Vamos citar e analisar aqui dois dos mais importantes e extrair sua influência nos projetos arquitetônicos do período, que não foi pouca coisa, e que acabaram por criar diretrizes, como será citado ao final do capítulo, e que alcançaram muitas das edificações construídas em quase todo o século XX.

\subsection{A fonte teórica: as propostas de Anísio Teixeira e Fernando de Azevedo}

Para compreender as construções escolares do século XX e até mesmo do início do século XXI em São Paulo, é necessário percorrer as propostas de Anísio Teixeira (19001971), o principal pensador da educação na década de 1920 e 1930 no país. Sua profunda relação com a arquitetura, vendo-a como poderoso instrumento de realização de suas pretensões pedagógicas, e sua inabalável crença na ciência, são direções que devem ser seguidas para verificar-se em que medida ou intensidade a arquitetura escolar feita na época estava realmente vinculada às propostas pedagógicas do escolanovismo e até que ponto a 
iniciativa de desenvolvimento de uma plástica moderna nessas edificações vinculava-se ao ideário educacional modernizador proposto por Teixeira e pelo poder público.

Baseando-se nas teorias de John Dewey e William Kilpatrick, que elaborou o conceito de "escola progressiva", Anísio Teixeira constitui a teoria da "escola nova", adequada a "uma civilização em mudança permanente" (TEIXEIRA, 2000, p. 24). Essa teoria foi desenvolvida no início da década de 1930 e publicada originalmente com o título "Educação progressiva: uma introdução à filosofia da educação”, em 1934 e publicado novamente em 1967 e em 2000. Para justificar essa proposta Teixeira procura demonstrar como a ciência - e, por conseguinte, o método científico - está na base de todas as transformações ocorridas nos séculos XIX e XX, tendo em paralelo uma visão otimista do uso desse conhecimento e da máquina, bem como as novas tecnologias, para o bem-estar da humanidade ${ }^{3}$.

E é a essa velocidade de transformação da sociedade que Teixeira busca uma escola de tempo integral, capaz de substituir a família e o meio social no que tange à educação das crianças $^{4}$ e de acompanhar as profundas mudanças introduzidas pela aplicação do conhecimento científico na natureza e suas conseqüências para as relações sociais. A justificativa para transformar a antiga escola em um "centro onde se vive" (TEIXEIRA, 2000, p. 46) passa também pela necessidade do ensino de uma moral e de um modo, a seu ver, mais correto, de viver em sociedade, e que seriam necessárias para o ensino da democracia. E o aprimoramento desse pensamento social e moral - assim propõe Teixeira - passaria necessariamente pelo uso do "método experimental" que aprimora o próprio pensamento científico, o que somente é possível de ser disseminado em larga escala através da educação formal.

Mais do que isso, percebendo que não deveria se limitar a transformar a escola em uma reprodução do que acontece na sociedade, para assim preparar os homens a se inserirem

\footnotetext{
3 "Nos últimos cento e cinqüenta ou cento e sessenta anos, graças ao método experimental de conhecimento, a subjugação das forças naturais foi simplesmente maravilhosa". (TEIXEIRA, 2000, p. 109).

4 “A necessidade, pois, de a escola tomar, em grande parte, a si, as funções da família e do meio social, corresponde a uma verdadeira premência dos nossos tempos, se quisermos das às nossas crianças a oportunidade de se adaptarem e se ajustarem à ordem social do nosso vertiginoso presente". (TEIXEIRA 2000, p. 40).
} 
melhor nela mesma, como acontecia também na escola antiga por ele mesmo criticada, Teixeira preocupa-se em transformar a escola em um meio de renovação social.

De outro lado, a partir de 1933, quando era diretor Geral da Instrução Pública de São Paulo, Fernando de Azevedo propõe e institui o Código de Educação do Estado (BUFFA; PINTO, 2002), modificando a legislação escolar. Nesse código, seguindo a idéia de ampliação dos atributos que a escola deveria ter, Azevedo insere diversas finalidades para a nova escola, indo muito além da educação tradicional e utiliza um termo curioso para complementar as suas propostas: “condições higiênico-pedagógicas dos prédios a serem construídos”. Em consonância com as propostas higiênicas que vigoravam desde o final do século XIX no Brasil, essa visão vai de encontro ao nome do novo ministério criado por Getúlio Vargas, o Ministério da Educação e Saúde.

O vínculo entre saúde e educação vai além dessa formalidade nominal. O Código de Obras do município de São Paulo, o conteúdo do livro "Novos prédios para grupos escolares" e os projetos feitos por José da Silva Neves, influenciados pelas escolas "platoon", feitas no Rio de Janeiro, revelam uma relação intensa entre a higiene e a saúde pública - que são eminentemente conquistas da ciência - e a arquitetura feita para escolas públicas.

Todos os sistemas de arquitetura propostos a partir da década de 1930 irão incluir em seu repertório um conjunto de soluções que são, em parte, uma conseqüência da aplicação das conquistas da ciência na área da saúde. Assim foi desde a introdução do sistema "platoon" até o final da década de 1950.

Uma definição clara do que é o sistema "platoon"5 nos é fornecida por Hélio Duarte: (...) o que caracteriza a escola "platoon" fisicamente falando é a simultaneidade de uso das salas de aula feita possível graças à descriminação (sic) e separação das matérias em dois grandes grupos ou "Platoons" possibilitando assim que num determinado momento estejam as crianças em atividades chamadas fundamentais (home-room-subjects) isto é, recebendo instruções de ensino fundamental ou em atividades especiais (special subjects). (DUARTE, 1973, p.12)

\footnotetext{
5“Platoon" em inglês significa pelotão.
} 
A crença profunda que muitos dos reformadores do ensino e os próprios arquitetos que pretendiam modificar a arquitetura feita no país - tinham na ciência e nas suas aplicações, estava apoiada, em grande parte, na capacidade que o uso desse conhecimento teria, segundo eles acreditavam, de transformar a sociedade através da educação. Sendo assim, ao considerála como parte integrante do processo educacional, a arquitetura deveria se beneficiar das conquistas científicas e técnicas para alcançar seu objetivo final, contribuir para a educação e, portanto, da transformação da sociedade. O desenho do projeto passa a ter uma fonte de recursos conformadores do espaço, provenientes de várias áreas do conhecimento científico, e com um objetivo definido em relação à educação.

\subsection{O planejamento da rede física escolar na década de $\mathbf{1 9 3 0}$}

Durante a pesquisa feita no riquíssimo acervo da EDIF foi constatado que foi feito entre 1933 e 1934 um levantamento das escolas existentes na cidade de São Paulo, construídas em anos bastante anteriores. Essas escolas, de caráter arquitetônico eclético receberam algumas reformas e/ou ampliações, inclusive algumas projetadas por José da Silva Neves. A relação colocada a seguir revela o alto grau de interesse do município em conhecer e controlar o conjunto de edificações destinadas ao ensino existentes na cidade, como revelam os cuidadosos desenhos que foram encontrados. Muitas dessas escolas, ao que se pôde verificar, foram demolidas e em seu lugar foram construídos outros edifícios. Em outros casos foram feitos anexos para receber mais alunos. De uma maneira geral, são edificações pequenas, e cuja arquitetura já não mais se adequava ao que era proposto e esperado pelos organizadores da educação no início da década de 1930. Os desenhos sem identificação de data mais precisa também são anteriores a 1933, pois se trata de projetos que foram redesenhados para o levantamento.

Algumas dessas construções receberam reformas para adaptá-las não apenas para receber uma maior quantidade de alunos, mas também para se adaptar a novas propostas pedagógicas (como o acréscimo do galpão na G.E. Álvares de Azevedo) e para modificar sua 
aparência. Essas reformas não levavam em consideração qualquer aspecto existente das edificações antigas, como pode ser verificado pela enorme e gritante diferença entre os volumes acrescidos aos edifícios que não foram demolidos. A numeração indicada na primeira coluna não corresponde necessariamente a uma ordem cronológica exata.

\section{Tabela 1 - Pesquisa feita entre 1933 e 1934 sobre escolas construídas anteriormente}

\begin{tabular}{lll}
\hline Numeração & Nome da escola & $\begin{array}{l}\text { Data. Autor(es) do projeto e outras } \\
\text { informações }\end{array}$ \\
\hline S/ numeração & G.E. da Lapa / Pereira Barreto & $\begin{array}{l}\text { Projeto do arquiteto João Bianchi } \\
(02.08 .1911) . \text { Reformado pela CE em 1956. }\end{array}$ \\
\hline DOP 2 & G.E. Frontino Guimarães & Reformado em 1950. \\
\hline DOP 3 & G.E. Regente Feijó & Reformado em 1953 pela CE \\
\hline DOP 8 & G.E. João Kopke & $\begin{array}{l}\text { O primeiro projeto é datado de 1911. Foi } \\
\text { reformado por J. Neves em 1940 e pela CE } \\
\text { em 1951 e 1952. }\end{array}$ \\
\hline DOP 10 & G.E. Santos Dumont & Projeto datado de 18.07.1911 \\
\hline DOP 11 & G.E. Marechal Deodoro & $\begin{array}{l}\text { Há uma data (19.08.1947), mas não foi } \\
\text { possível verificar se era de reforma ou de } \\
\text { levantamento. }\end{array}$ \\
\hline DOP 12 & G.E. Paulo Eiro (sic) &
\end{tabular}

\begin{tabular}{lll}
\hline DOP 13 & G.E. do Cambuci / A. Bayex & \\
\hline DOP 15 & G.E. do Braz (sic) & \\
\hline DOP 16 & G.E. Eduardo Prado & \\
\hline DOP 17 & G.E. Arthur Alvim & \\
\hline DOP 18 & G.E. Canuto do Val & \\
\hline DOP 20 & G.E. Vila Madalena & $\begin{array}{l}\text { Projeto original de } 1903 \text { e reformado em 1934 } \\
\text { DOP } 21\end{array}$ \\
\hline
\end{tabular}

DOP $22 \quad$ G.E. Aristides de Castro

\begin{tabular}{lll}
\hline DOP 23 & G.E. Pedro I & \\
\hline DOP 26 & G.E. Julio Ribeiro & Reformado em 1926 e 1954. \\
\hline DOP 29 & G.E. Pedro II & Reformado em 1939.
\end{tabular}

Há um projeto mais recente de R. Reviglio, datado dede 28.08.1937.

\begin{tabular}{lll}
\hline DOP 32 & G.E. Oswaldo Cruz & Reformado em 1947/48 pelo DOP \\
\hline DOP 34 & G.E. Buenos Aires & $\begin{array}{l}\text { Projeto datado de 23.04.1912. } \\
\text { Reformado em 1947. }\end{array}$ \\
\hline DOP 35 & G.E. Romão Puiggari & \\
\hline DOP 36 & G.E. Amadeu Amaral & Projeto datado de 11.08.1911. \\
\hline DOP 37 & G.E. Congonhas do Campo & $\begin{array}{l}\text { Foram encontradas somente plantas de } \\
\text { reformas, não sendo possível verificar em que } \\
\text { época o prédio foi iniciado. }\end{array}$ \\
\hline DOP 41 & G.E. Maria Zélia & \\
\hline
\end{tabular}

\begin{tabular}{lll} 
DOP 41 & G.E. Maria Zélia & \\
\hline DOP 42 & G.E. Álvares de Azevedo & $\begin{array}{l}\text { Data original do projeto não identificada. } \\
\text { Recebeu acréscimo de um galpão pela CE. }\end{array}$ \\
\hline DOP 43 & G.E. do Cambuci & \\
\hline DOP 47 & G.E. São Vicente de Paula & Reformado em 1939 \\
\hline DOP 50 & G.E. da Parada Inglesa & $\begin{array}{l}\text { Projeto datado provavelmente entre 1934 e } \\
1950 .\end{array}$ \\
\hline
\end{tabular}

DOP $53 \quad$ G.E. Arnaldo Barreto 


\begin{tabular}{|c|c|c|}
\hline DOP 58 & G.E. Rodrigues Alves & O primeiro projeto está datado de 21.07.1911. \\
\hline DOP 63 & $\begin{array}{l}\text { Instituto de Educação Fernão } \\
\text { Dias Paes }\end{array}$ & Sem identificação de data. \\
\hline DOP 93 & G.E. Marechal Floriano & Reformado pela CE em 1952. \\
\hline DOP 95 & G.E. Barra Funda & Projeto original datado de 13.02 .1911$. \\
\hline
\end{tabular}

\subsection{Ciência e Arquitetura: o Art Déco a serviço da educação}

Em 1936, ano do concurso para o Ministério da Educação e Saúde, cujo resultado final é um dos marcos da arquitetura mundial, ainda eram realizados tanto na capital paulista, quanto na capital federal, projetos de escolas com formas amplamente vinculadas ao que se convencionou chamar posteriormente de Art Déco. Naquele momento, o governo do estado, sob a administração de Armando Salles Oliveira, introduz algumas perspectivas modernas na realização dos projetos de escolas, com ampla valorização de questões eminentemente técnicas, tais como preocupação com implantação e insolação e uso de novas técnicas construtivas, quantificação de alunos e elaboração de pesquisas para atender à demanda de vagas na escola pública.

Essa situação ocorria também no então Distrito Federal, com a diferença que no Rio de Janeiro as propostas de arquitetura para escolas pretendiam ser modelos a serem seguidos pelo restante do país. A implantação dessa arquitetura não se deu sem crítica. Muito pelo contrário, suscitou amplos debates e controvérsias ${ }^{6}$, destacando-se os projetos de edifícios escolares de Enéas Silva na então capital do país. A crítica de José Mariano Filho, feita em 1943, sobre as novas escolas, construídas de acordo com um padrão estético bastante distinto do ecletismo que vigorava no país de uma forma geral, chama de "caixa d'água envidraçada" os "mastodontes de cimento" onde deveriam se alojar os "nobres edifícios públicos"”. Sua crítica, ainda que não tenha sido possível confirmar isso, pretende atingir tanto a arquitetura do Art Déco quanto a arquitetura moderna influenciada por Le Corbusier. Se durante a década de 1930, apesar da eliminação da decoração superficial das fachadas e das formas exageradamente detalhadas do ecletismo e neo-colonial, ainda há alguma preocupação por

\footnotetext{
${ }^{6}$ Cf. SEGAWA, 1997, pp. 66-68.

${ }^{7}$ SEGAWA, 1997, p. 66.
} 
parte dos arquitetos que produziram escolas com características Art Déco com algum enriquecimento do aspecto externo das edificações, o mesmo não se poderá dizer das escolas produzidas durante a década de 1940 e 1950, quando a forma de conceber o projeto muda totalmente, inclusive do ponto de vista de seu aspecto externo e organização espacial.

Apesar do elevado grau de interesse exposto por aquela administração da capital paulista em reduzir o déficit de vagas, foram construídas na cidade apenas 11 escolas. Aquelas construídas na cidade de São Paulo tinham características arquitetônicas que não estavam presentes naquelas construídas no interior do estado. Essas qualidades eram: o interesse com a insolação como determinante fundamental do projeto, uso de espaços específicos para lazer, circulação, o início da utilização de novas técnicas construtivas, entre elas o concreto armado, que possibilitava a criação de espaços cobertos sob a edificação. $\mathrm{O}$ dimensionamento das salas de aula e a quantidade de alunos que cada uma deveria conter são alguns dos critérios através dos quais as perspectivas de educação influenciam decisivamente aspectos da arquitetura.

A concepção arquitetônica baseava-se em um raciocínio que, se por um lado continha uma forte organização dos espaços em torno da separação setorial entre as funções que o edifício deveria conter, por outro lado o resultado formal alcançado ao final da construção traduz uma volumetria muito mais uniforme do que a somatória de uma série de diferentes funções poderia pressupor de início. A “concepção por extrusão" pode explicar esse raciocínio plástico, que se distingue de uma idéia de funcionalidade determinante dos espaços. Nessa forma de compor o edifício, é inegável que a presença dos futuros usos é fundamental, pois são eles que fornecem a referência principal em torno da qual os setores da escola irão funcionar. Esses espaços são os resultados da proposta pedagógica da escola renovadora, ou escola nova como ficou mais conhecida. Essa proposta resultou em uma variedade ampla de usos e seus respectivos ambientes. Também considerava o edifício escolar não apenas como um local de ensino das letras, matemática e disciplinas comuns ao ensino 
tradicional, mas sim como um local com características assistencialistas. Daí a inserção de usos como salas para dentistas e enfermaria, refeitórios, áreas para prática esportiva, entre outros. Isso resultou na convivência de tantos usos diferentes dentro de uma mesma edificação ou conjunto de edificações, tornando-se um padrão adotado até hoje.

A multiplicidade de usos existentes dentro das escolas é revelada externamente pela volumetria daqueles edifícios. A sua arquitetura é resultado de um volume extrudado a partir de um contorno definido no chão e alçado aos céus, com uma solidez digna de um edifício que deveria aparentar certa austeridade (figura 1). Esse contorno é resultado da separação dos usos internos da escola. O que se passou a denominar Art Déco era o claro resultado dessa concepção arquitetônica, configurando uma arquitetura que trazia a solidez dos edifícios mais antigos, sem a ornamentação profusa e eclética - tão criticada naquele momento - e o uso de elementos construtivos considerados ultrapassados e que estão presentes nas escolas construídas até a década de 1920.

Porém, apesar do conjunto arquitetônico revelar volumetricamente os usos que estão nele contidos, a massa construída possui tal unidade arquitetônica, que esta se sobrepõe à organização espacial interna, como as imagens dos edifícios e os projetos da época indicam. Portanto, a concepção arquitetônica gera uma construção que se utiliza dos seus espaços internos como parte integrante da sua composição unitária. Esse tipo de raciocínio, que busca uma unidade plástica baseada na unidade volumétrica, voltaria a comparecer aos projetos de escolas como meio principal de elaborar os projetos a partir do final da década de 1950, apesar das diferenças de ordem construtiva e formal.

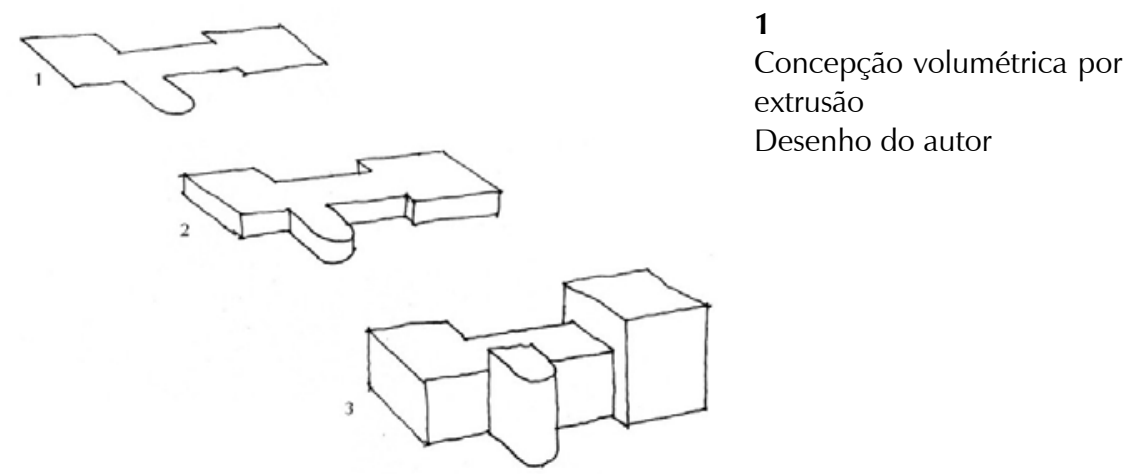


Esse tipo de concepção volumétrica é visualizado a partir das plantas de escolas da época (figura 2), como o Grupo Escolar Padre Manoel da Nóbrega. Pode-se assim comparar a planta com o desenho da elevação (figura 3) e perceber a relação linear entre ambos.

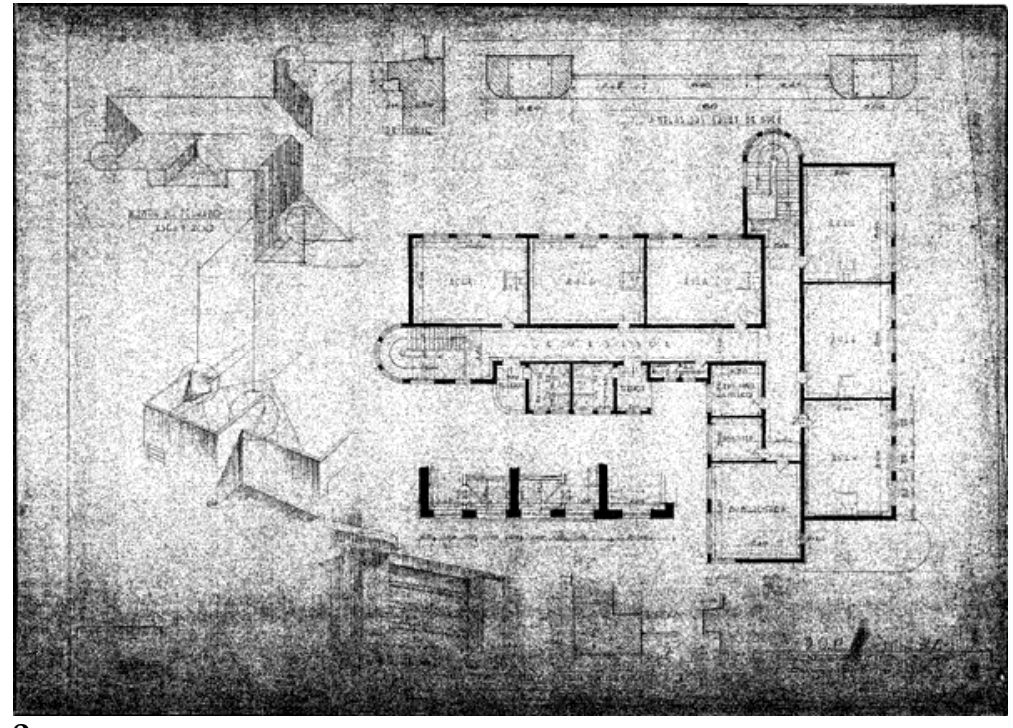

2

Grupo Escolar Padre Manoel da Nóbrega

Autor: H. Penteado (?)

1938

Fonte: Arquivo EDIF-PMSP

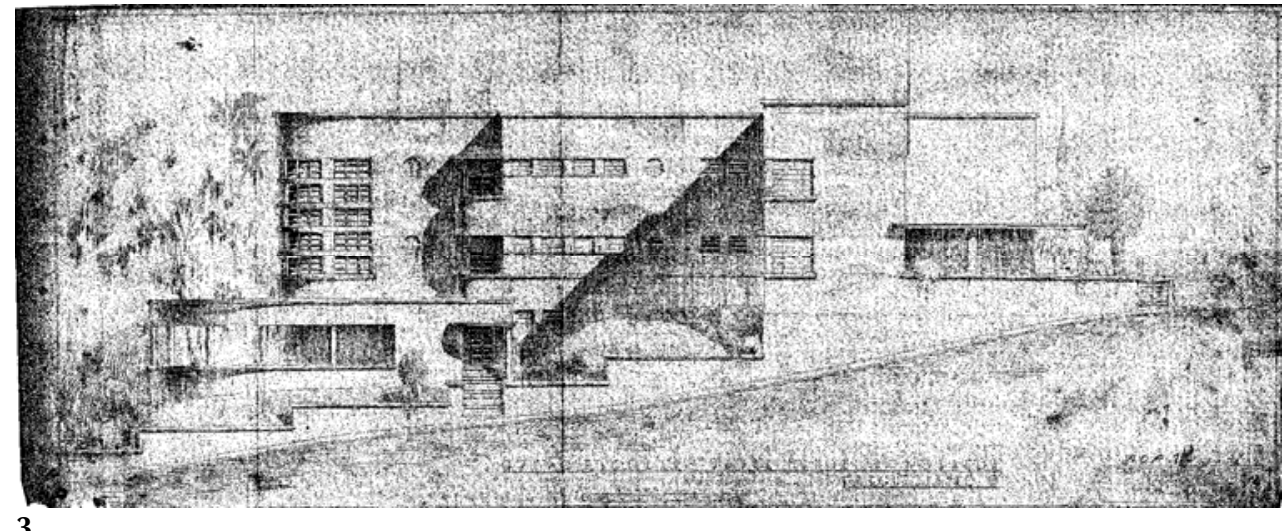

3

Grupo Escolar Padre Manoel da Nóbrega

Autor: H. Penteado (?)

1938

Fonte: Arquivo EDIF-PMSP

Isso não quer dizer que não houvesse interesse no acabamento final das superfícies externas do edifício. Ao contrário, o uso de filetes, planos, marquises, detalhes de guardacorpos, janelas com formas diferenciadas, mas sempre com vínculos geométricos, aplicados na edificação, faziam parte do rico repertório desse momento. Curiosamente esses elementos que compunham as elevações do prédio eram feitos normalmente com tijolos, ou no caso de 
construções mais simples, como residências, com pequenas diferenças de relevo na argamassa de acabamento externa (figura 3). Mas, normalmente, eram elementos arquitetônicos que não procuravam qualquer referência histórica conhecida. De fato, o resultado formal muitas vezes buscava a aparência das máquinas que se impunham com força na vida do país e no próprio mundo ocidental: os navios e trens, com suas formas aerodinâmicas, para citar alguns dos elementos mais reconhecidos pelos historiadores da arte e arquitetos que se dedicaram a estudar esse momento da arquitetura denominado Art Déco. Nesses elementos não há nada de simples, apesar da sua geometrização: surgem nessas construções muitos elementos formais que estavam aparecendo - com outra organização espacial e justificativa ideológica - nos projetos modernos da década de 1920 e começo da década de 1930.

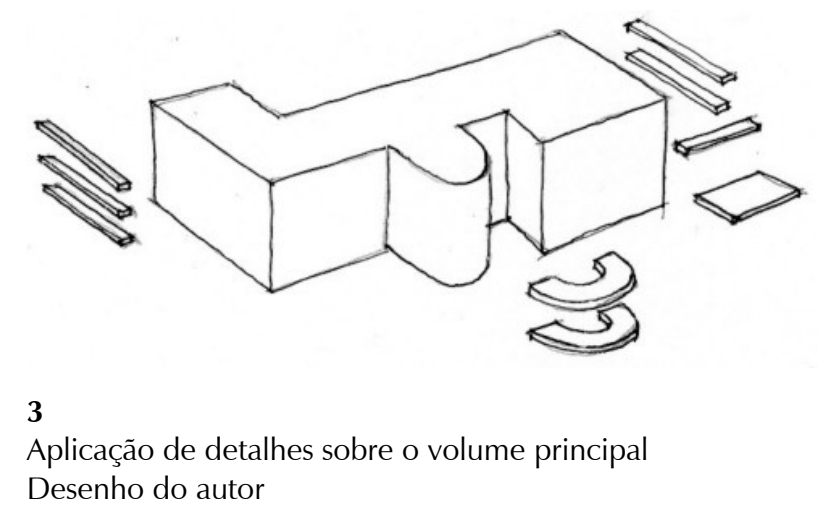

A adoção dessas formas pretendia colocar a arquitetura no mesmo patamar de desenvolvimento em que se pretendia inserir o processo educacional no Estado. As formas geometricamente euclidianas dessa arquitetura pretendiam, como se pode ver pela própria organização do livro "Novos prédios para grupo escolar", estar à altura, como solução plástica de um edifício, à aplicação de conhecimentos provenientes da ciência na definição de vários aspectos do espaço da escola. É possível verificar ainda que esse ideal modernizador era próprio dos participantes da Comissão - que elaborou o livro citado - encarregada de avaliar o problema da educação pública. Esse conjunto de soluções fazia parte de uma visão que considerava a imagem e a arquitetura da escola como algo extremamente importante, 
representativo dos avanços que o Estado se propunha fazer. Observe-se, no entanto que o volume de obras efetivamente necessárias não foi realizado.

Nessa comissão participaram ativamente, entre outros, o engenheiro Francisco Prestes Maia e o arquiteto José Maria da Silva Neves (1896-1978), responsável por muitos dos projetos de escolas construídas na cidade. José da Silva Neves também lecionou na Faculdade de Arquitetura e Urbanismo da Universidade de São Paulo, quando ainda era localizada na rua Maranhão. Nas figuras 4 e 5 verifica-se a arquitetura praticada então, horizontal, com uma rica composição volumétrica, como convinha a um edifício público considerado de extrema importância no período.

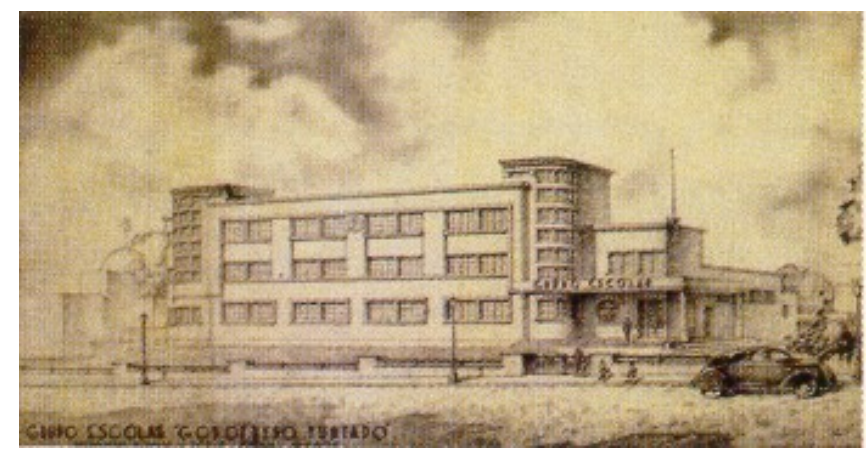

4

Grupo Escolar Godofredo Furtado - ilustração (EEPSG Godofredo Furtado)

Autor: José Maria Silva Neves

Fonte: CORRÊA (1998), p.23

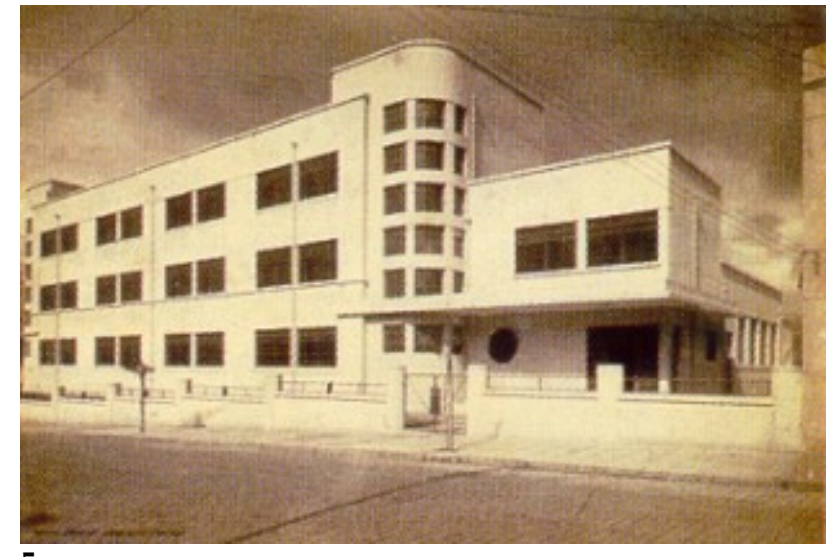

5

Grupo Escolar Godofredo Furtado - foto da fachada

(EEPSG Godofredo Furtado)

Autor: José Maria Silva Neves

Fonte: CORRÊA (1998), p.23

O conjunto de escolas construídas nos anos que se seguiram foi feito pelo governo do estado e pela prefeitura. No caso do estado o responsável pelos projetos era a Secretaria de 
Viação e Obras Públicas, através da sua Diretoria de Obras Públicas, e no caso da Prefeitura era o Departamento de Obras Públicas. As atividades que envolveram os arquitetos que trabalhavam para os dois D.O.P.'s também incluíam a reforma de escolas construídas anteriormente. Essas reformas procuravam descaracterizar os edifícios existentes. Não se verificou nenhuma intenção nos projetos de adequar ou aproximar o desenho dos novos anexos (no caso de ampliações de salas de aula ou obras com outras finalidades) à arquitetura dessas construções pré-existentes, muitas das quais, nitidamente, também não haviam sido construídas com a finalidade de escolas. Como já foi dito, muitas foram demolidas e deram lugar a edifícios com características muito distintas. A lista colocada a seguir foi obtida em levantamento feito no acervo da EDIF.

\section{Tabela 2 - Lista das escolas construídas entre 1936 e 1947}

\begin{tabular}{|c|c|c|}
\hline Numeração & Nome da escola & $\begin{array}{l}\text { Data. Autoria do projeto. Outras } \\
\text { informações }\end{array}$ \\
\hline DOP 1 & G.E. Padre Manoel da Nóbrega & $\begin{array}{l}\text { 12.08.1938. Projeto de H. Penteado. } \\
\text { Reformado em } 1949 .\end{array}$ \\
\hline DOP 19 & G.E. da Vila Esperança & 17.08.1944. Projeto de Paganelli. \\
\hline DOP 24 & G.E. São Paulo & 11.06.1937. Autor não identificado. \\
\hline DOP 25 & G.E. José Bonifácio & $\begin{array}{l}\text { 01.06, } 25.05 \text { e } 17.05 .1937 \text {. José Maria da } \\
\text { Silva Neves. O desenho do projeto inclui } \\
\text { pilastras clássicas com capitel e caneluras. }\end{array}$ \\
\hline DOP 28 & G.E. Godofredo Furtado & $\begin{array}{l}1937 \text { e } 1938 \text { (uma data para cada folha do } \\
\text { projeto). José Maria da Silva Neves. } \\
\text { Reformada pela CE. }\end{array}$ \\
\hline DOP 35 & G.E. Romão Puiggari & 25.09 .1936 \\
\hline DOP 43 & G.E. Oscar Thompson & $\begin{array}{l}\text { Aumento e reforma em 1944, com projeto de } \\
\text { Paganelli, feita sobre um edifício existente. }\end{array}$ \\
\hline DOP 45 & G.E. João Vieira d'Almeida & $\begin{array}{l}\text { 23.11.1937 e 08.01.1938. José Maria da Silva } \\
\text { Neves }\end{array}$ \\
\hline DOP 48 & G.E. Eduardo Carlos Pereira & $\begin{array}{l}\text { 29.10.1942, } 01.10 .1942 . \text { Reformado pela CE } \\
\text { em } 1950 \text { e } 1953\end{array}$ \\
\hline DOP 51 & G.E. Antonio Queiroz Telles & Sem data. \\
\hline DOP 52 & G.E. Sacoman & $\begin{array}{l}\text { 17.03.1937. Já havia uma pequena edificação } \\
\text { que foi levantada em 1933. O segundo } \\
\text { edifício é da autoria de José Maria da Silva } \\
\text { Neves }\end{array}$ \\
\hline DOP 54 & G.E. Alfredo Bresser & Sem data. \\
\hline DOP 57 & G.E. Silva Jardim & Sem data. \\
\hline DOP 59 & G.E. Expedicionário Brasileiro & $\begin{array}{l}\text { A cópia do projeto é datada de } 24.03 .1952 \text {. O } \\
\text { projeto é anterior a essa data, pois parece ser } \\
\text { bem mais antigo. Foi encontrada uma única } \\
\text { planta. }\end{array}$ \\
\hline DOP 60 & G.E. Pedro Arbues & 11.09.1948. Reformas em 1954 e 1955 , pela \\
\hline
\end{tabular}




\begin{tabular}{|c|c|c|}
\hline & & $\begin{array}{l}\text { CE, feitas por José E. Ganzoli, R. Cardieri e } \\
\text { Rubens F. Azevedo. }\end{array}$ \\
\hline DOP 65 & G.E. Mário de Andrade & $\begin{array}{l}\text { 08.08.1947 e } 10.05 .1948 \text {. Projeto feito por } \\
\text { Ghaesela. }\end{array}$ \\
\hline DOP 66 & $\begin{array}{l}\text { G.E. de Osasco / Marechal } \\
\text { Bitencourt }\end{array}$ & 30.01.1948. O projeto é de João del Nero \\
\hline DOP 67 & $\begin{array}{l}\text { G.E. Vila Olímpia } \\
\text { Dispensário Médico Escolar }\end{array}$ & 12.12.1946. Projeto de Ghaesela \\
\hline DOP 67 & $\begin{array}{l}\text { G.E. Martim Francisco } \\
\text { Dispensário Médico Escolar }\end{array}$ & 07.08.1947. Projeto de Ghaesela. \\
\hline DOP 69 & G.E. Visconde de Itauna & $\begin{array}{l}\text { 29.08.1947, 18.08.1947 e um estudo de } \\
\text { acústica de 08.10.1947. Autor não } \\
\text { identificado. }\end{array}$ \\
\hline DOP 84 & G.E. Miss Browne & $\begin{array}{l}\text { 18.11.1948. O nome de J. A. Toledo está } \\
\text { como autor da planta de esquadrias. } \\
\text { Reformado em 21.01.1954. }\end{array}$ \\
\hline GE 94 & G.E. Prof. Theodoro Moraes & $\begin{array}{l}\text { 1936. Reformas em 1950, } 1954 \text { e } 1971 \text {. Foi } \\
\text { levantada em 1946. Certamente, devido à } \\
\text { data, foi construída pelo DOP. }\end{array}$ \\
\hline $\begin{array}{l}\text { DOP } 96 \\
\text { DOP } 30\end{array}$ & G.E. Bosque da Saúde & 30.01.1936. José Maria da Silva Neves \\
\hline DOP 102 & G.E. Vila Gomes Cardim & $\begin{array}{l}\text { 27.02.1936. José Maria da Silva Neves e } \\
\text { Ernesto S. de Freitas }\end{array}$ \\
\hline
\end{tabular}

\subsection{Legislação, educação e arquitetura}

A legislação também abrangia, ainda que de uma maneira diferente da que foi indicada até aqui, os edifícios escolares. O Código de Obras Arthur Saboya (lei n. 3.427, de 19 de novembro de 1929), da Prefeitura de São Paulo, fornecia diretrizes tanto para acabamentos quanto para dimensionamentos internos das escolas. No texto pode-se perceber que há uma visão de relação entre espaço e ensino também:

VI) - Escolas

Art. $405 .^{\circ}$ - Nas escolas, os revestimentos das paredes internas devem ser executados, tanto quanto possivel for, com materiaes permittindo lavagens freqüentes".

Paragrapho unico - A forma rectangular será a preferida para as salas de classe e os lados do rectangulo guardarão relação de 2 para 3.

(São Paulo (cidade) 1929, p. 283-284.)

Essa legislação, como era comum na época, deitava normas sobre a higiene do ambiente, mas o que chama a atenção é a presença de normas que seriam relativas a decisões pedagógicas sobre a arquitetura. Nesse sentido, o Código de Obras Arthur Saboya, tanto na lei 
mostrada abaixo, quanto mais tarde no ato que a regulamentou, procura intervir na educação através da própria arquitetura:

Art. $406 .^{\circ}$ - A illuminação das salas de classe será unilateral esquerda, tolerada, todavia, a bilateral esquerda-direita differencial.

Paragrapho $10^{\circ}$ - A illuminação artificial preferida será a electrica, tolerada, todavia, a illuminação a gaz ou a álcool, quando convenientemente estabelecidas.

Paragrapho $2 .^{\circ}-$ As janellas das salas de classe serão abertas na altura de um metro, no minimo, sobre o soalho, e se approximarão do teto tanto, quando possivel.

Art. 407. ${ }^{\circ}$ - As escolas terão um pavimento apenas, sempre que possivel, e porão de cincoenta centimetros, no minimo, convenientemente ventilado.

Art. $408 .^{\circ}$ - As escadas das escolas serão de lanço recto e seus degraus não terão mais de dezeseis centimetros de altura nem mesmo de vinte e oito de largura.

Art. $409 .^{\circ}$ - As dimensões das salas de classe serão proporcionaes ao numero de alumnos: estes não excederão de quarenta em cada sala e cada um disporá, no minimo, de um metro quadrado de superficie, quando duplas as carteiras, e de um metro e trinta e cinco decimetros quadrados, quando individuaes.

Art. $410 .^{\circ}$ - A superficie total das janellas de cada sala de classe corresponderá, no minimo, á quinta parte da superficie do piso.

Art. $411^{\circ}-$ A altura minima das salas de classe será de quatro metros. Art. 412..$^{\circ}$ - Haverá uma latrina para cada grupo de vinte alumnos ou de trinta alumnos e um lavabo para cada grupo de trinta alumnos ou alumnas. Paragrapho único - $\mathrm{O}$ assento das latrinas será de preferencia em fórma de ferradura aberta na frente.

O código que regulamentava as construções no município de São Paulo englobava a legislação sobre aspectos gerais da edificação, mas também estabelecia normas relacionadas à organização urbana da cidade e a aspectos estritamente técnico-construtivos. Sua abrangência, portanto, ia desde a divisão radiocêntrica da cidade, passando pelos aspectos gerais da edificação, tais como dimensionamento, gabaritos, exigências específicas para determinados tipos de uso, chegando a normas técnicas bastante detalhadas.

As informações sobre escolas vão se repetir, em parte, no ato que regulamentou o Código Arthur Saboya. Essa regulamentação, datada de 1934, solicita o seguinte:

II - Escolas

Art. 435 - As escolas terão um pavimento apenas, sempre que possível, e caixa de $\operatorname{ar}^{8}$ de cincoenta centimetros no minimo, convenientemente ventilada.

\footnotetext{
${ }^{8}$ Caixa de ar é sinônimo de porão, situado logo abaixo do piso do pavimento térreo. Em São Paulo as construções de porão alto começaram a popularizar-se no final do século XIX (N. do A.).
} 
Art. 436 - As escadas das escolas serão de lance réto e seus degraus não terão mais de dezeseis centimetros de altura nem menos de vinte e oito de largura.

Art. 437 - As dimensões das salas de aula serão proporcionais ao numero de alunos; estes não excederão de quarenta em cada sala e cada um disporá, no minimo de um metro de superficie, quando duplas as carteiras, e de um metro e trinta e cinco decimetros, quando individuais.

Art 438 - A altura minima das salas de classe será de quatro metros.

Art. 439 - A iluminação das salas de classe será unilateral esquerda, tolerada, todavia, a bilateral esquerda direita diferencial.

Art. 440 - A iluminação artificial preferida será a eletrica, tolerada, todavia a iluminação a gas ou alcool quando convenientemente estabelecida.

Art. 441 - As janelas das salas de classe serão abertas na altura de um metro no minimo, sobre o assoalho e se aproximarão do této tanto quanto possivel.

Art. 442 - A superficie total das janelas de cada sala de classe corresponderá no minimo, a quinta parte da superficie do piso.

Art. 443 - A forma retangular será a preferida para as salas de classe e os lados do retangulo guardarão a relação de dois para três.

Art. 444 - Haverá uma latrina para cada grupo de vinte alunas ou de trinta alunos e um lavabo para cada grupo de trinta alunos ou alunas.

(Código de Obras Arthur Saboya, 1934, p. 363-364)

A regulamentação do Código Arthur Saboya, de 1934, englobava a legislação sobre aspectos gerais da edificação, mas também estabelecia normas relacionadas à organização urbana da cidade e a aspectos estritamente técnico-construtivos. Não há grandes diferenças em relação à lei promulgada em 1929, como se pode verificar na leitura dos dois textos.

A abrangência do código ia desde a divisão radiocêntrica da cidade, passando pelos aspectos gerais da edificação, tais como dimensionamento, insolação, arruamentos, gabaritos, e exigências específicas para determinados tipos de uso, chegando a normas técnicas bastante detalhadas. Tratava-se de um manual bastante útil no que se refere à execução de obras, pois trazia consigo uma série de exigências e soluções que deveriam ser adotadas na construção. Ë possível encontrar com freqüência no código cálculos construtivos e sua aplicação, e até especificações de materiais e suas aplicações. Esse código pode ser considerado não apenas um conjunto de leis sobre a cidade e sua arquitetura, mas também um manual de informações técnicas construtivas.

As normas referentes a edifícios escolares soam bastante simples e restritas aos nossos olhos. Por outro lado, é relevante observar que há, no código, preocupações com a higiene da construção e dimensionamentos mínimos, inclusive quantidade de alunos por sala de aula. 
Há ainda um trecho que discorre sobre o que se denominava "arquitetura das fachadas". As escolas também estavam submetidas a essas exigências. A parte da arquitetura a que ambos os códigos, de 1929 e 1934, referem-se especialmente é a das chamadas "fachadas", mas também envolvia gabaritos e recuos. As normas deveriam ser seguidas, caso contrário a Diretoria de Obras e Viação poderia recusar os "projetos de fachadas". Era um capítulo que tratava de uma "censura estética" (Código de Obras Arthur Saboya, 1929, p. 292).

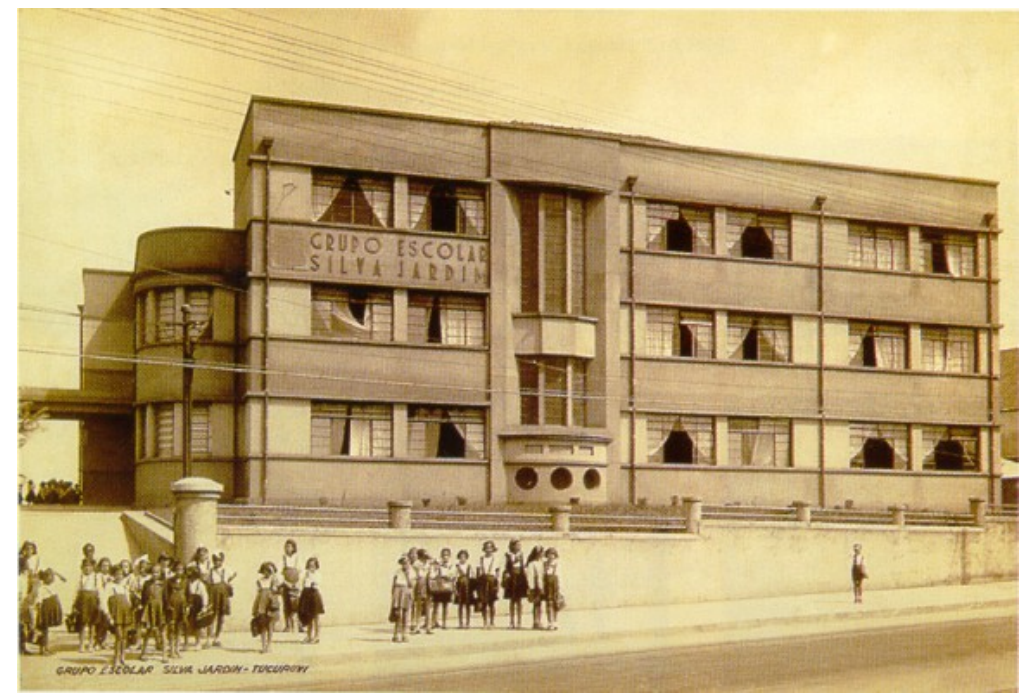

6

Grupo Escolar Silva Jardim - foto da fachada (EEPG Silva Jardim)

Autor: José Maria Silva Neves

Fonte: CORRÊA, 1998, p. 23

É difícil avaliar com precisão o alcance dessa legislação nos edifícios analisados, mas a questão da iluminação, como na figura 6, parece ter sido uma constante a ser resolvida nos projetos. Nas fachadas do Grupo Escolar Silva Jardim se nota um cuidado com o desenho do volume, com a sua composição arquitetônica. Em nenhum momento, porém, essa composição se sobrepõe ao volume maciço que configura formalmente a construção. A técnica construtiva está a serviço da solidez e densa monumentalidade de um edifício público.

A legislação, de uma maneira indireta, absorveu as lições impostas pelas conquistas científicas que geraram a higiene e as noções modernas de saúde, e transferiu-as para as escolas, ainda que de forma parcial. A avaliação do alcance do conhecimento científico, 
principalmente as questões de saúde e higiene relacionadas à arquitetura, absorvidas e consolidadas como prática profissional pela legislação dos códigos de obra municipais merece um trabalho específico mais aprofundado.

\subsection{Os projetos na década de 1930: concepção por extrusão}

O projeto datado de 1936 do Grupo Escolar Bosque da Saúde (posteriormente denominado EEPG Princesa Isabel) - ver figuras 7 e 8 - possui alguns dos elementos arquitetônicos característicos do período, da maneira como era aplicado em São Paulo: o uso de uma volumetria com um desenho geometrizante muito vinculado à arquitetura Art Déco, e que corresponde à decoração das fachadas. Alguns historiadores também denominam essa arquitetura de protomoderna, pois contém alguns elementos considerados precurssores da arquitetura moderna propriamente dita:

1. uso de sistemas construtivos que posteriormente seriam muito explorados pela arquitetura moderna;

2. eliminação de qualquer vestígio aparente de ornamentação que lembrasse qualquer figura, imagem ou aparência de arquiteturas ecléticas;

3. e por utilizar uma volumetria externa ligada ao uso dos espaços internos.

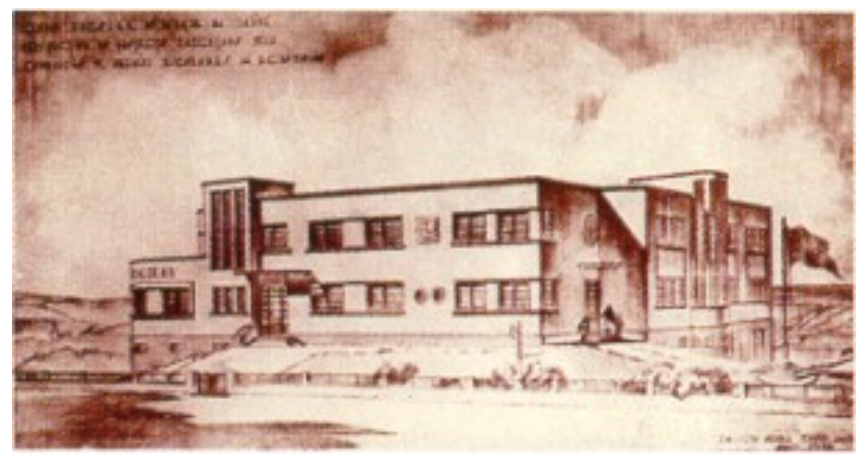

Grupo Escolar Bosque da Saúde - perspectiva

(EEPG Princesa Isabel)

Autor: José Maria Silva Neves

Fonte: CORRÊA (1998), p. 23

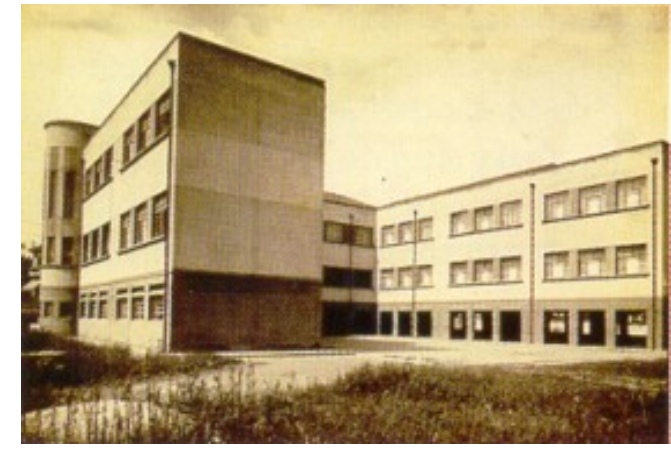

8

Grupo Escolar Bosque da Saúde

(EEPG Princesa Isabel)

Autor: José Maria Silva Neves

Fonte: CORRÊA (1998), p. 23 
Essa construção também contém os princípios da nova proposta pedagógica que surgia então: número maior de salas de aula, banheiros internos ao edifício, criação do pátio coberto para recreio das crianças, e instalações completas para que a escola esteja à altura do que lhe era exigido: formar o novo cidadão, com uma cultura eminentemente urbana, leiga e que procurava ir além do ensino de letras e matemática. Do edifício escolar era exigida uma modernidade à altura do seu papel como centro de formação plena de cidadãos. Para isso a escola tem instalações como cozinha, ambiente para refeições, sala de dentista e amplo local para recreio.

Para materializar esse espaço, apesar da disponibilidade de técnicas construtivas baseadas no concreto armado que permitiriam inovações em termos de organização espacial, a volumetria gerada para a construção ainda está vinculada a um processo de extrusão em muito semelhante às construções de estrutura autoportante feitas até o século XIX, e que foi aqui denominado de "concepção volumétrica por extrusão". Ou seja, a partir de um risco bidimensional em planta confere-se uma altura a essas linhas e depois se coloca uma cobertura, fechando o volume, como se aquela massa construída se erguesse diretamente a partir do solo. Tal forma de construir aparece no projeto, ainda que as decisões a respeito do traço bidimensional sejam essencialmente funcionais, ou seja, a volumetria emite variações externas que correspondem diretamente ao seu uso interno. Sobre essa volumetria ainda maciça, apesar da estrutura ser independente, são aplicados janelas e frisos em alvenaria que, como já foi dito, corresponderiam à antiga ornamentação. A escolha da composição das fachadas, com formas geométricas definidas, fazia parte do repertório formal da época (figura 9).

No Rio de Janeiro, construíam-se, ao mesmo tempo, o Ministério da Educação e Saúde, desenvolvido a partir de um risco de Le Corbusier pela equipe de Lúcio Costa, e o Palácio Duque de Caxias, do então Ministério do Exército, de autoria de Cristiano Stockler 
das Neves ${ }^{9}$, com suas formas maciças e pesadas, de geometria austera e rígida. Isto indica que não havia predominância desta ou daquela arquitetura no Rio de Janeiro ou em São Paulo, nas construções oficiais. Esse fato irá se confirmar na década de 1940, quando há uma convivência de diferentes arquiteturas para escolas públicas na capital paulista.

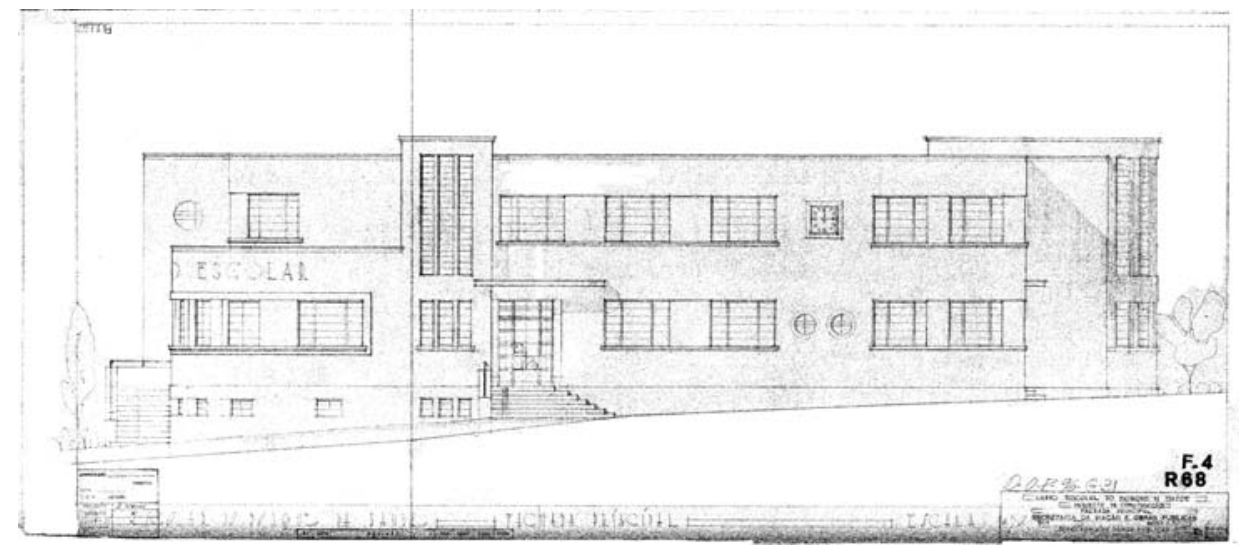

9

Grupo Escolar Bosque da Saúde - fachada

(EEPG Princesa Isabel)

Autor: José Maria Silva Neves

Fonte: Arquivo EDIF - PMSP

A relação entre a planta e o volume extrudado é visível no projeto da EEPG Visconde de Congonhas do Campo (figura 10).
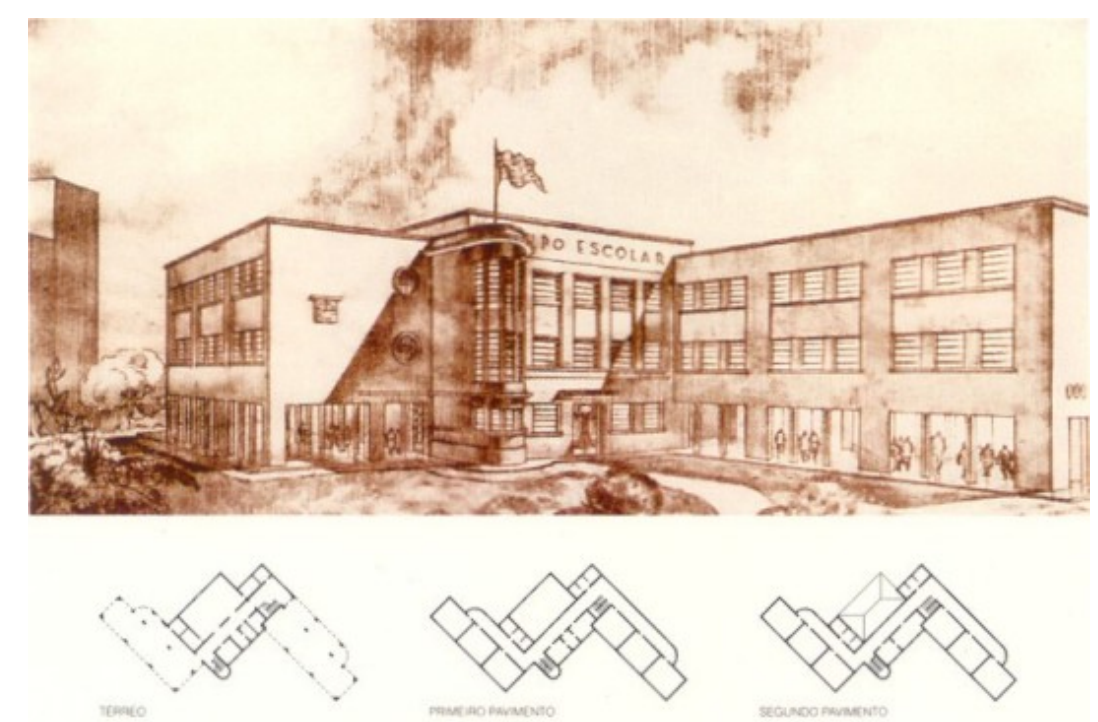

10

EEPG Visconde Congonhas do Campo - perspectiva e plantas

Autor: José Maria Silva Neves

Fonte: CORRÊA (1998), p. 23

${ }^{9}$ CZAJKOWSKI, 2000, p. 28. 
O fato de haver um pátio coberto sob o volume total da edificação, como ocorre também no projeto do grupo escolar Bosque da Saúde, não contribui para quebrar a volumetria definida pelos limites definidos horizontalmente em planta. Nesse ambiente só não há as paredes definidoras, por se tratar de um pátio, mas seus limites estão totalmente dentro da volumetria extrudada a princípio. O pátio coberto foi uma importante conquista técnica, em edifícios que pretendiam ter o menor custo possível.

\subsection{O modelo de escola e a modernidade oficial}

As escolas construídas no período de 1920 e 1930 no Distrito Federal, que era no Rio de Janeiro, no antigo estado da Guanabara, pretendiam ser modelos a serem seguidos, como efetivamente o foram. Portanto as escolas têm de ser necessariamente vistas sob a ótica da reprodução de um discurso, materializado em uma forma que se pretendia modernizadora, mas também encarregada da afirmação de um Estado que fosse capaz, junto a uma nova proposta pedagógica, de inserir a criança e o adolescente em um modo de vida que até então muito poucos tinham acesso. A tímida, porém contundente, ampliação da rede física da educação primária e ginasial não resolveria esse problema nos anos seguintes. Essa exigência feita acerca sobre o novo edifício escolar gerava a necessidade de tantos usos diferentes tendo de conviver junto em um mesmo ambiente. A educação formal, a saúde, a alimentação, as atividades físicas e o exercício da disciplina paramilitar e de uma moral religiosa faziam parte desse conjunto de atividades, tentando tornar a escola não apenas capaz de suprir uma parte da vida do aluno, mas também tentando interferir, como pretendia Anísio Teixeira, na vida do próprio aluno (Cf. DUARTE, 1973, p. 37-38).

No Distrito Federal, que na época estava situado no Rio de Janeiro, Anísio Teixeira implanta o tipo "platoon" pela primeira vez no Brasil. Coube ao arquiteto Enéas Silva a tarefa de realizar os projetos dos edifícios que deveriam ampliar a rede física de ensino da capital brasileira. Primeiro foram executados os edifícios "nucleares", que deveriam conter somente 
as aulas das disciplinas fundamentais, e depois seriam feitas as escolas do tipo "platoon" propriamente dito (cf. DUARTE, 1973, p.21).

A dissertação de mestrado de Beatriz Santos de Oliveira, intitulada "Modernidade oficial: a arquitetura das escolas públicas do Distrito Federal (1928-1940)" explica como as escolas projetadas nas décadas de 20 e 30 do século XX no Distrito Federal pretendiam ser modelos a serem seguidos por todas as administrações públicas brasileiras e justifica o seu período de análise:

As escolas públicas, neste caso mereceram nossa atenção porque, mais que simples escolas, são estabelecimentos do domínio e controle do poder público. O governo se encarrega da materialização de sua política educacional através da implantação de um sistema de educação que tem as escolas públicas como central de expressão e consolidação.

A construção dos seus edifícios obedece a um programa previamente traçado pelas instituições estatais incumbidas da organização e planejamento escolar. Estes programas ou requerimentos para projetos, normas construtivas e padrões de conforto físico-ambiental são necessariamente informados pelos modelos e tendências de ensino que balizam a execução dos termos eficientes que se espera obter com a ação educativa. Tal aparato institucional criado para "pensar" a escola, para organizá-la e controlá-la, desde o currículo à construção, dá ao estabelecimento escolar público características próprias que lhe distinguem e ao seu projeto.

As escolas de $1^{\circ}$ grau que foram construídas no antigo Distrito Federal (Rio de Janeiro), no final dos anos 20 e nos anos 30, nos interessaram particularmente por estarem inseridas dentro de um projeto de reforma educacional que pretendia ser exemplo para todo o país. Os planos em Educação, realizados na capital federal, eram concebidos como modelos a serem seguidos por todas as administrações públicas brasileiras e daí sua relevância para o nosso estudo que quer refletir sobre o grau de influência das determinações sociais globais sobre a forma, enquanto expressão plástica e organização espacial. (OLIVEIRA, 1991, pp. X-XII).

As propostas de unificar as formas arquitetônicas a serem produzidas pelos arquitetos (prática comum a muitos dos CIAM - Congresso Internacional de Arquitetura Moderna) não eram exclusivas da área habitacional, mas também percorriam os edifícios escolares. Em sua dissertação de mestrado, Beatriz Oliveira revela que no IV Congresso Pan-Americano de Arquitetos, realizado em 1930, prescreviam-se duas conclusões. A primeira recomendava "que os arquitetos (...) mostrassem aos poderes públicos 'a necessidade de fomentar o estudo e a aplicação da arquitetura de caráter nacional' de modo que essa fosse 'capaz de cumprir sua finalidade social moderna' (leia-se atendimento aos programas funcionais)" (OLIVEIRA, 
1991, p. 127). A segunda conclusão recomendava que a arquitetura dos edifícios escolares fosse "inspirada em um sentido de tradição regional, com o objetivo de despertar no espírito da criança o sentido da própria nacionalidade" (OLIVEIRA, 1991, p. 128). A expressão "arquitetura de caráter nacional" remete quase que invariavelmente ao neocolonial. Porém, essas conclusões não foram aplicadas nos projetos de escolas identificados nesta pesquisa.

Várias condições já eram propícias a um aprimoramento maior da arquitetura escolar, tanto em termos de experiências distintas da arquitetura neocolonial praticada no início do século XX, quanto da abertura de possibilidades de realizações que antes eram mais limitadas no que se refere a construção de escolas, principalmente em termos de quantidade e da aplicação dos novos conhecimentos científicos aplicados à educação:

a) O Ministério da Educação e Saúde Pública foi criado em 1930;

b) Em 1930 a opinião de que "a educação era o meio mais adequado e efetivo de transformação das condições reais em que nos encontrávamos" já era um consenso político (OLIVEIRA, 1991, p. 134).

c) A introdução do Escolanovismo;

d) A criação de um Plano Nacional de Educação;

e) O surgimento de planos locais de educação pelo país, incluindo-se o estado de São Paulo e mais especificamente a capital paulista, que é por onde começaria a construção das novas escolas.

Dessa maneira criam-se as condições para o que deveria ser a modernização da arquitetura destinada a criar os edifícios escolares capazes de abrigar uma proposta de educação inovadora.

Para Anísio Teixeira, a educação que ele propunha "requeria espaços adequados" e uma "base física e preliminar para o programa educacional planejado" (OLIVEIRA, 1991, p. 144). Um dos ideais da Escola Nova era que "boa educação era um direito de todos e 
precisava de boa arquitetura para realizar-se, portanto, boa arquitetura escolar era também direito de todos os cidadãos" (OLIVEIRA, 1991, p. 149).

O que chama a atenção no texto de Oliveira é a afirmação de que em 1934, excluindose o programa de construções escolares do Rio de Janeiro, apenas o do Rio Grande do Sul teria alguma qualidade a ser apresentada:

Mas isto nos é revelado, de maneira particularmente expressiva, através da iniciativa da Associação Brasileira de Educação, de organizar, em 1934 (5/5/34 a 31/05/34), a primeira exposição de Arquitetura Escolar, da qual seguiu-se uma segunda em 1935, nos salões da Escola Nacional de Belas Artes. (...) Foram, naturalmente, por demais ambiciosos os objetivos da A.B.E., e todo esse empenho em relação aos prédios escolares não conseguiu passar da $2^{\mathrm{a}}$ Exposição, em 1935. (...) a ausência de um programa construtivo e a precariedade das construções escolares inibia a participação da maioria dos governos e revelava o descaso e o amadorismo com que se tratava a educação no Brasil. Uma das exceções neste quadro foi o Rio Grande do Sul que, sob a administração de Oswaldo Aranha, desenvolveu um trabalho semelhante ao carioca. (OLIVEIRA, 1991, pp. 216-220)

Somente em 1936 é que teria início, de fato, a consolidação das propostas na capital paulista para a criação de um sistema educacional, e, por conseguinte, de uma arquitetura condizente com sua proposta.

A análise da autora também aborda a aplicação de conhecimentos chamados de científicos nos projetos de escolas. A publicação "Novos Prédios para Grupos Escolares" é citada no tem 4.3, (OLIVEIRA, 1991, p. 226). Os dados científicos, bem como sua aplicação no projeto da escola, objetivando uma racionalidade funcional, impregnada por uma estética que privilegiava a "verdade construtiva" - ou seja, uma arquitetura de caráter ético - são questionados pela autora, ao afirmar que a definição dos mesmos "não vinha respaldada por qualquer estudo científico, mas apenas em aproximações baseadas numa questionável observação" (OLIVEIRA, 1991, p. 230). Para a autora "fica patente é que nossos números foram encontrados através de uma mediação, cujo princípio era o bom senso prático, entre os argumentos científicos estrangeiros e os 'argumentos técnicos filhos do desejo de economizar'." (OLIVEIRA, 1991, p. 227). 
Cumpre observar que dentro dessa visão ideológica e da proposta plástica que consolida a composição arquitetônica das escolas construídas nesse período, o uso de técnicas construtivas que permitissem estruturas independentes já era algo comum, mas que não era explorado na sua totalidade. Como sempre, o raciocínio dos arquitetos teria que esperar novas influências externas à técnica em si para ampliar as possibilidades plásticas das edificações escolares.

Depois da experiência no Rio de Janeiro, Anísio Teixeira é chamado para a Bahia para atuar como Secretário de Educação e Saúde. Em Salvador, propõe a sua proposta de ensino primário, dividida em dois pólos: as escolas-classe e as escolas-parque. Esse será o conceito que influenciará decisivamente Hélio de Queiroz Duarte, e que este tentará implantar na capital paulista quando estiver atuando à frente da Comissão Executiva (CE) do segundo Convênio Escolar.

É ainda na década de 1930 que irão se consolidar as principais diretrizes para projetos de escolas que serão utilizados durante quase 30 anos, tanto pelos projetos feitos pelo município quanto pelo estado, na cidade de São Paulo, a saber:

1. Posicionamento das salas de aula para a mesma orientação, o norte, criando os grupos lineares de salas de aula, com corredor de acesso em um lado apenas;

2. Multiplicidade de funções no edifício escolar, o que traz a necessidade de adequar, em termos de desenho e de circulação, ambientes com dimensões, necessidades e usos muito distintos entre si;

3. Pátio para recreio coberto e intimamente ligado à circulação;

4. Profunda preocupação com a insolação das salas de aula;

5. Os projetos são realizados acreditando-se que o espaço é parte fundamental do processo de ensino, apesar de não terem sido feitas quaisquer análises mais profundas sobre isso para sua efetiva aplicação nos desenhos para as novas construções; 
6. Baixo gabarito da edificação.

Esses aspectos eram características dominantes, mas havia algumas exceções. Cada um desses aspectos será modificado ao longo do tempo abrangido por esta pesquisa, mas de certa forma se manterão com intensidade até o final da década de 1950, quando alguns deles serão abandonados.

\subsection{Um período obscuro}

Tem sido uma unanimidade, nas pesquisas sobre o assunto, a afirmação de que pouco se fez no tocante à arquitetura escolar entre 1938 e 1947. A ocorrência de uma guerra em escala mundial, da qual o Brasil participou, pode ter contribuído para esse aspecto, ainda que possa haver outras explicações, como veremos mais adiante. Porém, foi possível identificar algumas escolas feitas pela Diretoria de Obras Públicas. Essas escolas foram feitas no período que é considerado por muitos como sendo um dos mais obscuros no século $\mathrm{XX}$, no que se refere à construção de edifícios escolares. As edificações identificadas não possuem o léxico arquitetônico moderno ao qual se associa as conquistas realizadas na década de 1930, quando houve um processo intenso de modernização do edifício escolar, com a introdução inclusive de pedagogias mais avançadas. As escolas, em um total de sete, são as seguintes: G.E. da Vila Esperança (DOP 19), de 1944, Dispensário Médico Escolar para o G.E. Vila Olímpia (DOP 67), de 1946, Dispensário Médico Escolar do G.E. Martim Francisco (DOP 67), de 1947 e G.E. Miss Browne, de 1948. Destes projetos não foi possível obter desenhos.

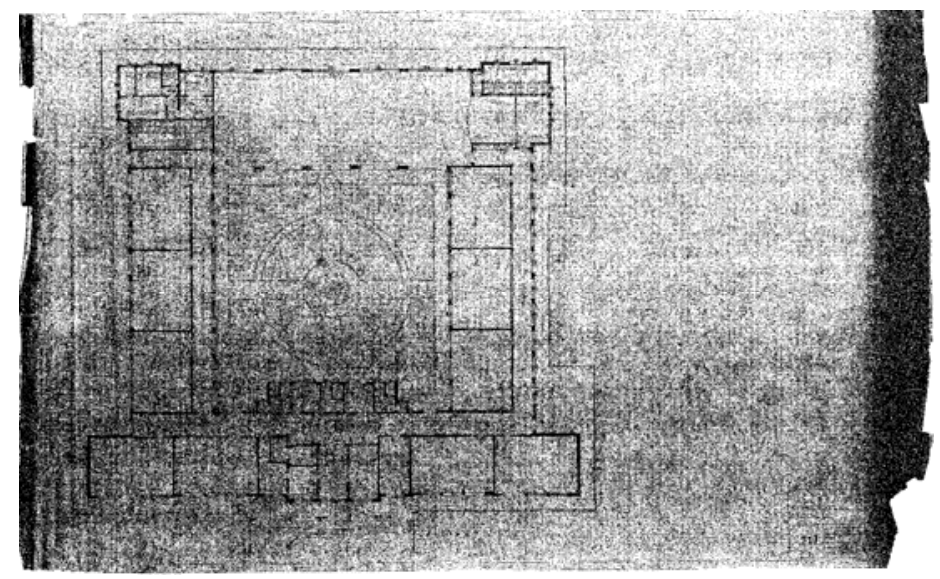

11

Grupo Escolar Mário de Andrade (DOP 65)

Autor: Ghaesela.

Há duas folhas de desenho, datadas de 08.08.1947 e 10.05.1948.

Fonte: Arquivo EDIF-PMSP 
Há ainda outros três projetos (figuras 11 a 16) desse período: G. E. Visconde de Itauna (DOP 69), G. E. Mário de Andrade (DOP 65) e G. E. Marechal Bitencourt (DOP 66).

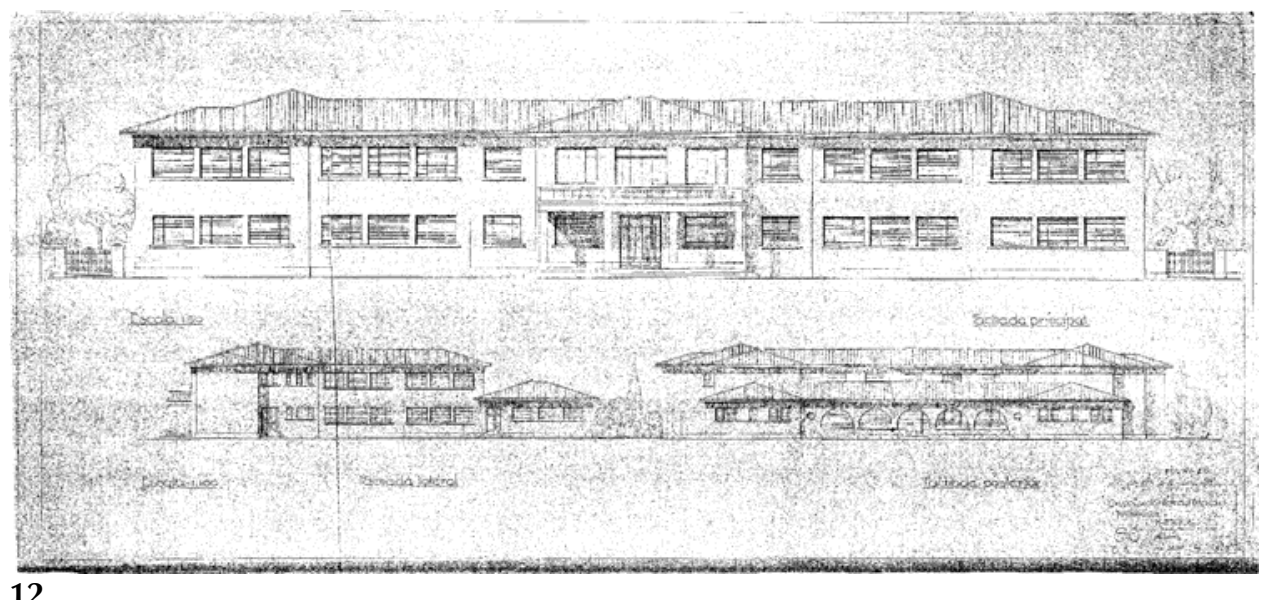

12

G.E. de Osasco / Marechal Bitencourt (DOP 66)

Elevações

O projeto é de João del Nero

30 de janeiro de 1948

Fonte: Arquivo EDIF - PMSP

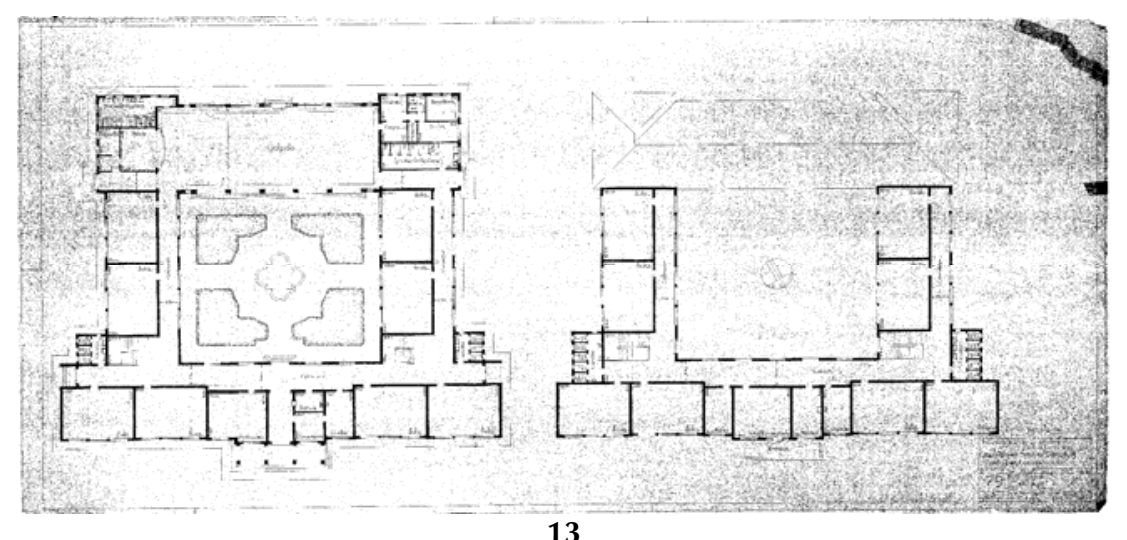

G.E. de Osasco / Marechal Bitencourt (DOP 66)

Plantas

O projeto é de João del Nero

30 de janeiro de 1948

Fonte: Arquivo EDIF - PMSP

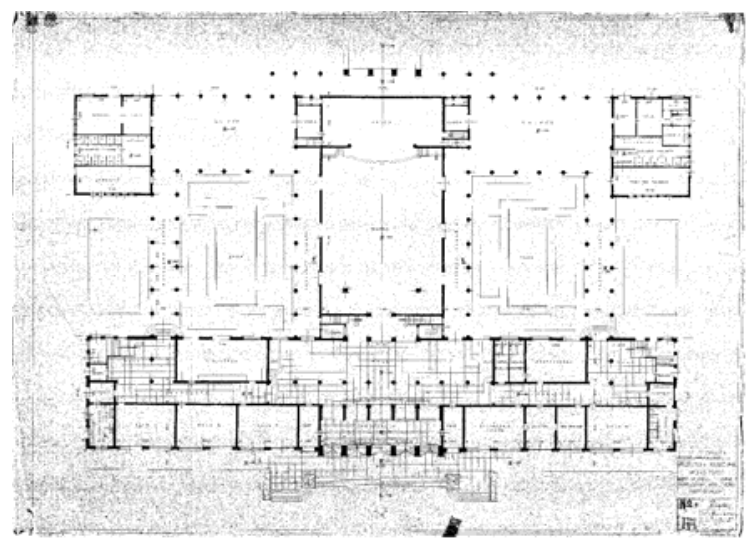

14

G. E. Visconde de Itauna (DOP 69) Autor: Ghaesela

Outubro de 1947

Fonte: Arquivo EDIF - PMSP 


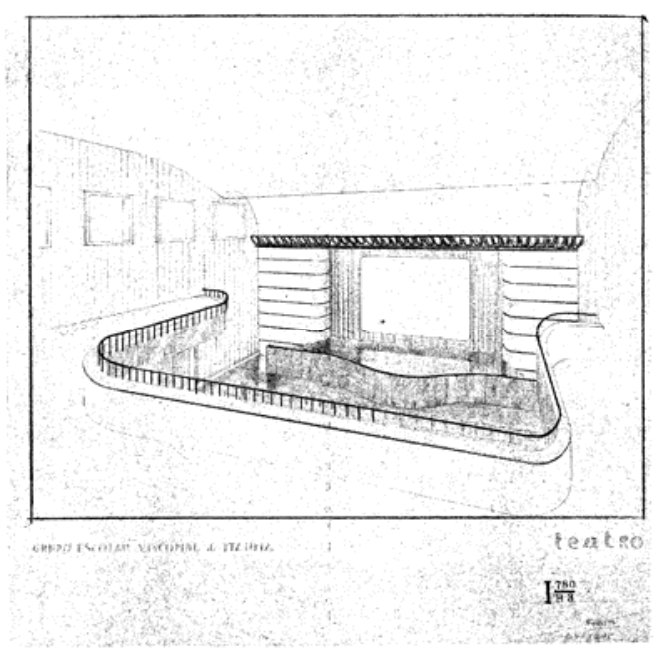

15

DOP 69 G.E. Visconde de Itauna

Projeto para o teatro da escola.

Autor: Ghaesela

8 de outubro de 1947

Fonte: Arquivo EDIF - PMSP

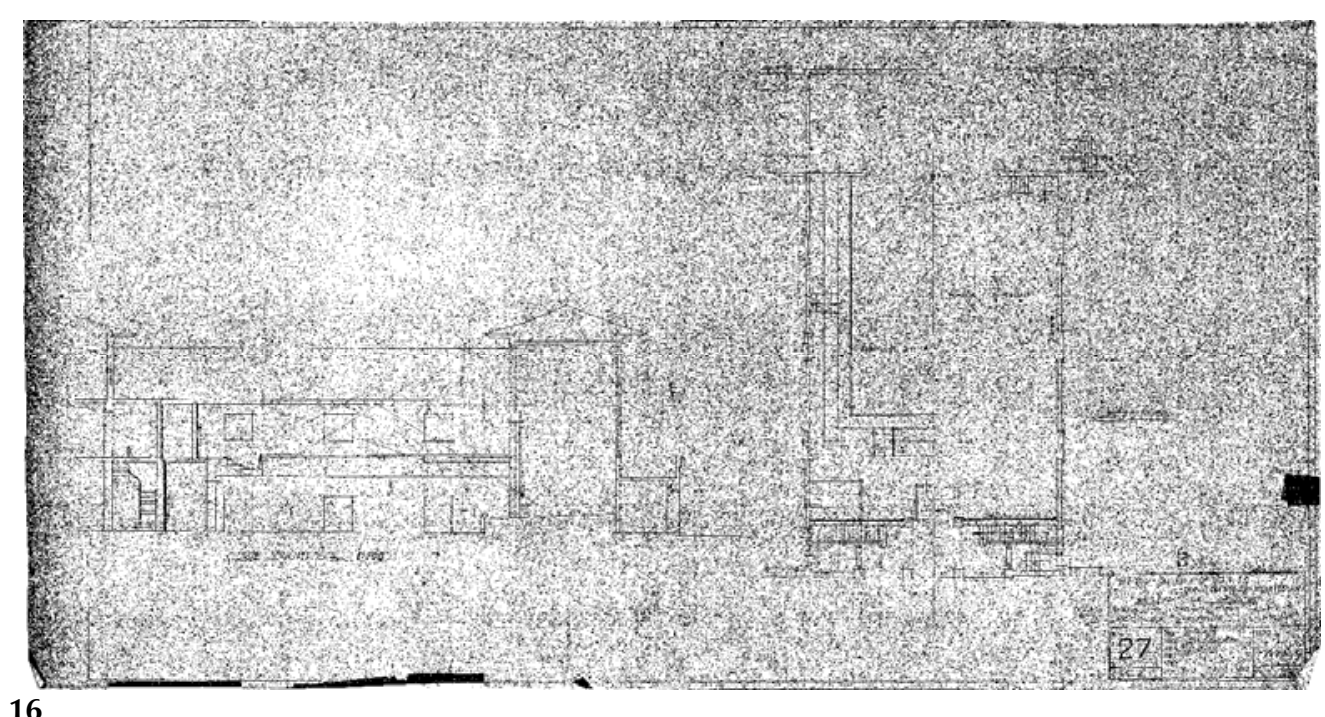

16

DOP 69 G.E. Visconde de Itauna

Estudo de acústica para o teatro da escola.

Autor: Ghaesela

8 de outubro de 1947

Fonte: Arquivo EDIF - PMSP

Todos os projetos pesquisados têm em comum um desenho que, surpreendentemente, sequer se aproxima dos projetos feitos em 1936, por José da Silva Neves. Neles, a arquitetura é organizada em torno de uma simetria de aparência eclética. Apesar disso, esta arquitetura contém um programa similar ao que foi feito anteriormente, ou seja, os espaços internos estão de acordo com algumas das premissas propostas nos projetos que pretendiam modernizar o edifício escolar na cidade de São Paulo. O que ocorre então é uma aparente contradição entre dois aspectos que pareciam afastados entre si:

1. O uso de uma organização espacial e uma construção cuja aparência final está muito mais próximo de um ecletismo romântico do início do século XX; 
2. A aplicação nessas escolas de um programa desenvolvido pelos escolanovistas e por engenheiros e arquitetos. Este fato surpreende ainda mais por haver uma associação quase rígida entre as propostas pedagógicas modernas introduzidas no Brasil a partir da década de 1920 e a noção de que deveria haver uma arquitetura mais adequada para a materialização, em certa medida, dessas propostas.

Junto a esses projetos foi encontrado um estudo de acústica para o teatro de uma das escolas (figuras 15 e 16), projetado por Ghaesela (não foi possível identificar seu primeiro nome nem sua formação). Os desenhos revelam que a predominância do Art Déco como solução arquitetônica para as escolas não era hegemônica. Além disso, verificou-se que mesmo nos projetos acima mostrados, a preocupação com a aplicação de conhecimentos técnicos provenientes de campos de conhecimento pertencentes à ciência estava presente, como no caso da acústica.

Essa relação, citada no segundo item, entre pedagogia e arquitetura é recorrente nos vários textos analisados. Nessa relação está profundamente arraigado um discurso cientificista, que afirma que um projeto será tanto melhor quanto mais se aplicar nele as mais recentes conquistas da ciência aplicada e da técnica construtiva. A qualidade do projeto estava associada à capacidade do arquiteto de aplicar nele as conquistas da ciência.

A arquitetura encontrada nos arquivos e reproduzida em parte neste item, não deve ser vista necessariamente como um retrocesso, pois de fato o programa está aplicado a essas construções da década de 1940. É possível afirmar, por outro lado, que o que ocorre de fato é a convivência de formas de organização espaciais e sistemas construtivos durante certo tempo. Não há uma delimitação temporal precisa, com início e fim desta ou daquela arquitetura, no caso das escolas públicas nas décadas de 1930 e a primeira metade da década de 1940. 
Em Salvador, Anísio Teixeira tomava a iniciativa de tentar implementar aquela que seria uma das suas propostas mais influentes, e que até hoje seduz vários grupos de arquitetos: o binômio escola-classe e escola-parque.

Anísio Teixeira, atuando em Salvador, com a contribuição de Hélio de Queiroz Duarte, que se tornou seu profundo admirador e promovedor de suas idéias, havia idealizado a construção de dez conjuntos de escolas para cobrir as deficiências da cidade. Porém, somente uma escola-parque foi construída (DUARTE, 1973, p. 7). Isso não impediu que essa proposta se disseminasse, e chegasse até São Paulo pelas mãos de Hélio Duarte.

Foi com o segundo Convênio Escolar que o programa da escola pública se beneficiou de uma outra maneira de pensar a arquitetura. Essa nova forma, que é a arquitetura moderna oficial, proveniente do Rio de Janeiro, porta de entrada das lições trazidas diretamente por Le Corbusier, é aplicada de maneira paralela em escolas feitas em outros municípios. A aplicação de conceitos modernos de arquitetura no programa escolar não foi uma exclusividade da $\mathrm{CE}$ em São Paulo. É o caso de Santo André, cidade vizinha à capital paulista, na qual foi construído um grupo escolar para um conjunto habitacional realizado pelo I.A.P.I. (Instituto de Aposentadoria e Previdência dos Industriários), com um total de 16 salas de aula ${ }^{10}$, da autoria de Carlos Frederico Ferreira ${ }^{11}$, que também foi um dos pioneiros da arquitetura moderna, formado também na Escola Nacional de Belas Artes no Rio de Janeiro. O projeto foi feito e executado no mesmo período em que tiveram início os trabalhos do segundo Convênio Escolar, sendo que em 1950 a escola que faz parte do conjunto habitacional já estava pronta. No artigo que apresenta o projeto da escola estão justificadas todas as dimensões e os tipos de mobiliário adotados para as salas de aula, bem como uma extensa análise de salas e mobiliários adotados em outros países. O projeto utiliza a composição aditiva (figuras 17 e 18), reunindo três volumes principais em torno de uma circulação

\footnotetext{
${ }^{10}$ Arquitetura e Engenharia (14): 53-61, jul. / set. 1950.

${ }^{11} \mathrm{O}$ arquiteto Carlos Frederico Ferreira foi um dos pioneiros da arquitetura moderna brasileira na Escola Nacional de Belas Artes. Foi chefe do setor de arquitetura e desenho da Divisão de Engenharia do IAPI e o principal responsável pela política de projetos do órgão, tendo sob sua responsabilidade uma quantidade muito grande de projetos (Cf. BONDUKI, 1998, p. 206).
} 
transversal, e separa nitidamente três grupos funcionais, hierarquizando-os (administração, áreas comuns e de lazer, e setor pedagógico). A semelhança com os projetos realizados pela CE impressiona, tanto pela implantação, quanto pela disposição das salas de aula e pela relação entre sistema estrutural e a forma final da edificação. Não foram identificados outros projetos de escola feitos por Ferreira A existência de soluções semelhantes ocorrendo em lugares próximos revela uma convergência de soluções arquitetônicas, menos pelos contatos entre si em São Paulo, mas certamente pela mesma formação acadêmica. Essa arquitetura escolar - pelo menos até o início da década de 1960 - não possui um único autor reconhecível, ainda que a influência da arquitetura de Le Corbusier e dos seus cinco pontos da arquitetura moderna tivesse forte presença nas escolas de arquitetura no país, principalmente no Rio de Janeiro. Parece ser mais uma conquista coletiva, tanto por parte o poder público, que aceita essa arquitetura, quanto por parte dos arquitetos, que adotam soluções projetuais em comum.

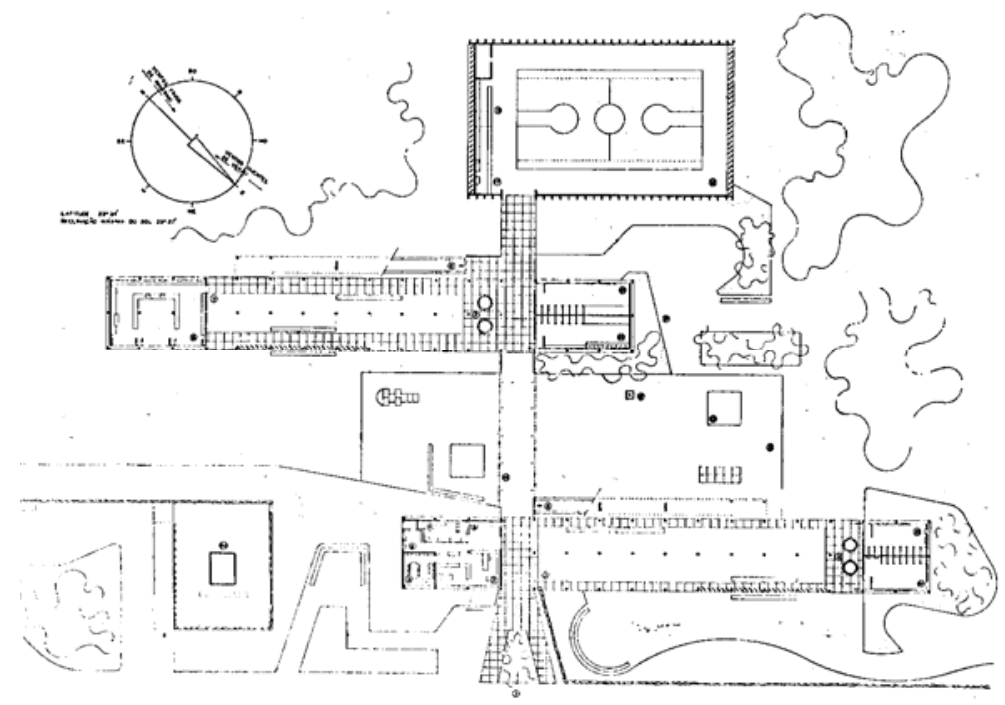

17

Grupo escolar do conjunto residencial de Santo André - I.A.P.I.

Planta do pavimento térreo

Autor: Carlos Frederico Ferreira

Fonte: Arquitetura e Engenharia (14): 56, jul. / set. 1950. 


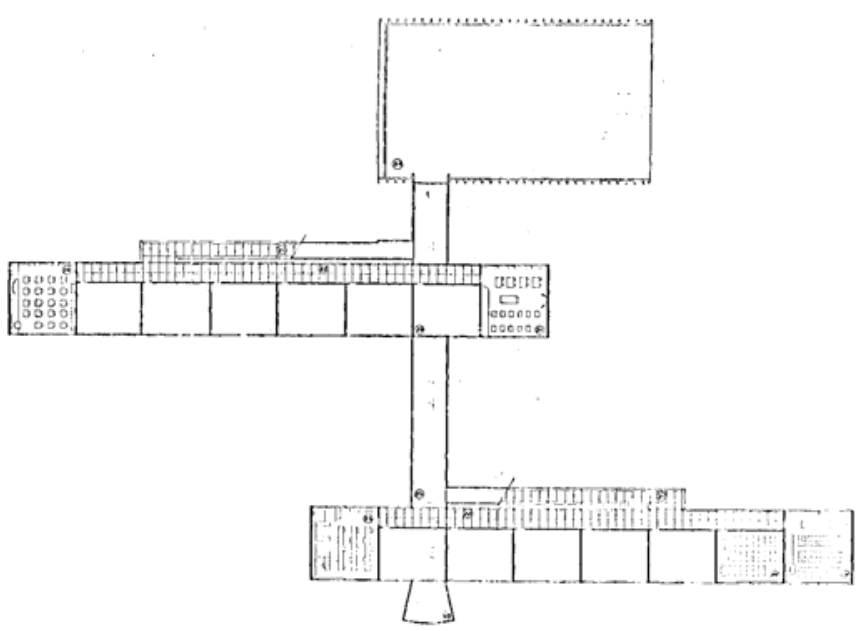

18

Grupo escolar do conjunto residencial de Santo André - I.A.P.I.

Planta do pavimento superior

Autor: Carlos Frederico Ferreira

Fonte: Arquitetura e Engenharia (14): 57, jul. / set. 1950.

Os arquitetos que desenvolveram os projetos de escolas públicas na cidade de São Paulo entre 1934 e 1948 não participaram das atividades da Comissão Executiva do segundo Convênio Escolar, estabelecido em 1948. Seus nomes não foram encontrados nos projetos ou em publicações que divulgaram os resultados da Comissão Executiva. 


\section{3}

A ampliação da rede física escolar do município:

1943 a 1954 


\subsection{O primeiro Convênio Escolar}

Os anos que se seguiram não modificaram muito o quadro existente até então na cidade de São Paulo. De $1943^{12}$ a 1948 , época em que funcionou o primeiro Convênio público voltado para a construção de espaços para educação, foram realizados apenas três edifícios. Essa situação parece ter sido causada, segundo artigo publicado anos após a extinção desse primeiro convênio, pela ausência de uma estrutura administrativa capaz de direcionar corretamente os recursos destinados para a construção de escolas.

Em uma conferência realizada em São Paulo em outubro de 1949, o eng. José Amadei relata o quadro das instalações destinadas à educação pública na cidade:

A situação, no ano de 1947 era a seguinte:

111 grupos escolares, dois funcionavam junto aos dois Institutos de Educação.

Dos 109 grupos restantes 34 funcionavam em prédios pertencentes ao Estado, sendo 28 em prédios especialmente construídos e 6 em prédios adaptados.

Os outros 75 funcionavam em prédios alugados, dos quais 13 especialmente construídos e os demais adaptados, na sua maioria necessitando de substituição tais as suas más condições higiênico-pedagógicas.

Alugueres em geral baixos, quasi todos os contrátos vencidos, alguns já sob a ação de despejo e outros de interdição.

$\mathrm{Na}$ sua maioria sob regime de aulas de três períodos.

258 eram as escolas isoladas e 214 as classes nas escolas agrupadas.

(...)

O problema da edificação para a escola primária logo se nos apresentou claro:

64 edifícios para substituir os existentes condenados e 37 edifícios para atender as 40.000 crianças sem instrução e sem escola tomando-se por base a média de nove salas por grupo que é a média fornecida pelos existentes.

Mas como o tresdobramento ${ }^{13}$ deve cessar, tais os seus inconvenientes, um terço a mais sobre o total de $146(109+37)$ elevaria o número de prédios necessários a 194. (AMADEI, 1959, p.8)

As dificuldades encontradas para o início dos trabalhos do primeiro Convênio Escolar são descritas por Celso Hahne, chefe da Contabilidade da Comissão de Construções Escolares, órgão que sucedeu a Comissão Executiva (CE) do segundo Convênio Escolar:

\footnotetext{
${ }^{12}$ Cf. Engenharia Municipal (12): 1, jan. / mar. 1959.

${ }^{13}$ Prática comum na época de usar uma mesma sala de aula em três períodos ao longo do dia, com alunos diferentes. O principal problema é que cada classe fica com seu horário dentro da sala de aula reduzida, além da necessidade de ocupar horários noturnos, o que nem sempre era adequado às crianças.
} 
(...) o primeiro Convênio firmado em 1943 praticamente não chegou a ser executado pela inexistência de um órgão técnico especializado que o puzesse em funcionamento. Assim é que as verbas destinadas ao ensino no período de 1943 a 1948 foram na sua quase totalidade creditadas no Fundo do Ensino, pois as repartições do Departamento de Obras e posteriormente da Secretaria de Obras não estavam entrosadas para a finalidade de construção de prédios escolares e suas instituições auxiliares. Tanto assim que nesse período (1943-1948) apenas três prédios escolares foram construídos. (HAHNE, 1959, p. 9)

Em 1946, a Constituição passou a determinar que União, Estados e Municípios investissem uma certa porcentagem dos recursos arrecadados na educação primária. Para atender a essa determinação, foi realizado mais um acordo, no caso da cidade de São Paulo, entre o governo do Estado e a Prefeitura, também denominado Convênio Escolar. Por este acordo, a Prefeitura, na administração de Milton Improta, seria responsável pela construção das escolas e edificações complementares, e ao governo do Estado, na administração Adhemar de Barros, caberia a manutenção do ensino.

Já existia uma prática, ainda que em certos momentos descontínua, de construção de escolas públicas por parte do governo estadual, e que abrangia tanto a capital quanto as cidades do interior paulista, estando essa responsabilidade na maior parte do tempo, e até 1960, relacionada diretamente à Diretoria de Obras Públicas. Somente a partir desse ano é que sistematicamente a construção de escolas estará sob a responsabilidade de um órgão constituído exclusivamente para esse fim. Até 1930, a construção desses edifícios não tem um ritmo contínuo, ainda que se possa afirmar que as cidades no interior foram mais bem atendidas que a capital, no que se refere à quantidade de edifícios. Essa irregularidade se repete com o segundo Convênio Escolar: trata-se ainda de um momento bastante definido no tempo e no espaço, tendo o ano de 1954 como data limite para atender os objetivos estabelecidos.

Além do atendimento às exigências da Constituição, o Convênio tinha como meta, certamente política em sua formulação, colocar todas as crianças da capital, em idade escolar, em instituições públicas de ensino até o ano de 1954, ano de comemoração do IV Centenário 
da cidade. Essa postura revela, por parte dos dirigentes do Estado, uma mudança significativa em relação à preferência normalmente dada às cidades do interior.

O Convênio deveria, portanto, ser responsável pela solução do problema da edificação voltada para a educação pública em toda a cidade, mesmo sendo, em essência, um instrumento temporário para a realização das metas estabelecidas pela Constituição, além de estar submetido à Diretoria de Obras Públicas. As metas eram claras: em 1954 não deveria haver nenhuma criança fora da escola. A direção da Comissão do Convênio Escolar, inicialmente dirigida pelo eng. José Amadei, incluindo o arquiteto responsável pela realização dos projetos, Hélio de Queiroz Duarte, sabiam da necessidade de impor uma grande velocidade à execução dos edifícios, em face da rapidez com que a cidade crescia demograficamente e geograficamente.

O gráfico 1, publicado na revista Habitat n. 4, revela a expectativa do Convênio de atender progressivamente a demanda até alcançar o objetivo final.

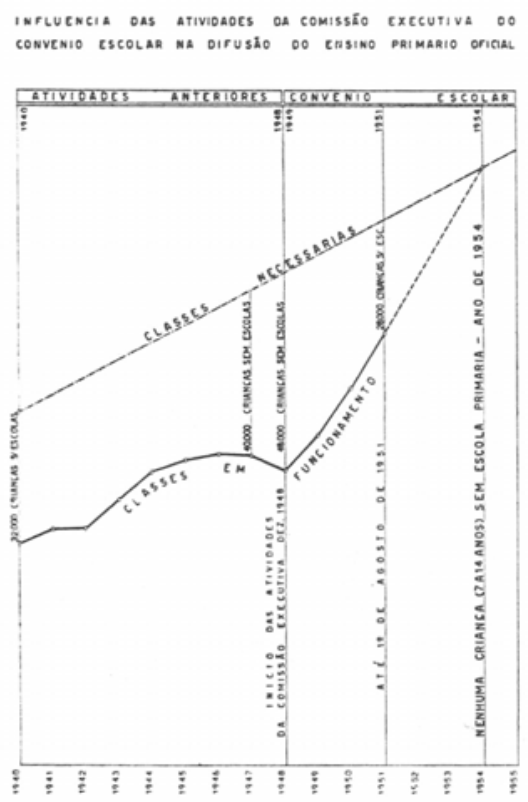

\section{Gráfico 1}

Influência das atividades da Comissão Executiva do Convênio Escolar na difusão do ensino primário oficial Fonte: AMADEI, 1951, p. 3.

O gráfico 1 revela ainda um outro aspecto que é pouco citado nas publicações e dados obtidos nesta pesquisa: segundo ele houve um aumento, ainda que pequeno em relação à demanda, no número de classes em funcionamento durante a Segunda Guerra Mundial. Nas 
pesquisas realizadas sobre as edificações escolares construídas no município de São Paulo, foram construídas pouquíssimas edificações novas durante esse período. Não foi possível verificar quais as fontes utilizadas pelo autor do artigo, o engenheiro José Amadei, para elaborar o gráfico, e é possível que esse pequeno aumento no número de classes entre 1942 e 1946 seja correspondente ou ao aumento no número de edificações destinadas a escola, ou a modificações na quantidade de turnos de aula, prática comum na época.

\subsection{A Comissão Executiva do segundo Convênio Escolar}

Para alcançar esses objetivos foi constituída, em fins de 1948, a Comissão Executiva do Convênio Escolar, a qual concentraria todas as atividades de planejamento, realização de projetos e execução de obras. Na ocasião da assinatura do segundo Convênio Escolar era prefeito do município de São Paulo o coronel Asdrúbal Eurítisses da Cunha e o governador aquele que seria um dos futuros prefeitos da cidade, Adhemar de Barros ${ }^{14}$. Ela se constituiu ao longo do tempo da seguinte forma:

A primeira Comissão Executiva do Convênio Escolar, no período de 1949 e 1953, ficou assim constituída: Presidente, Eng. ${ }^{\circ}$ José Amadei: chefe do setor de construções, Eng.o Ernesto de Faria Alves, chefe do setor de projetos, Arq. Hélio Queiroz Duarte e. finalmente, chefe do setor de contadoria, Celso Hahne.

Posteriormente, a presidência da referida Comissão. passou pelo seguintes modificações:

De 1953 à 1954 o Sr. Eng. ${ }^{\circ}$ Werther Krause

De 1954 à 1955 o Sr. Eng. ${ }^{\circ}$ José Amadei

De 1955 à 1956 o Sr. Eng. ${ }^{\circ}$ Maury de Freitas Julião

De 1957 à 1958 o Sr. Eng. ${ }^{\circ}$ Javme da Rocha Pereira

De 1958 até a presente data. o Sr. Eng. ${ }^{\circ}$ José Olavo de Freitas.

Quanto ao setor de construções:

De 1953 à 1954 o Sr. Eng. ${ }^{\circ}$ Armando de Arruda Camargo

De 1954 até esta data o Sr. Eng. ${ }^{\circ}$ Cyro Ribeiro Pereira

Quanto ao setor de projetos [sic]:

De 1952 à 1953 o Sr. Arq. Julio Cezar Lacreta

De 1954 à 1956 o Sr. Arq. Elvio Novelleto

De 1956 até a presente data, o snr. Arq. Raul Bolliger.

(Engenharia Municipal (13): 2, abr. mai jun. 1959.)

\footnotetext{
${ }^{14}$ Engenharia Municipal (13): 1, abr. / mai. / jun. 1959.
} 
A Comissão Executiva do Convênio Escolar, durante a sua existência, não construiu somente edifícios especificamente voltados para serem escolas, mas também uma série de equipamentos, que, indiretamente ou não, estavam voltados para a educação. Foram feitas bibliotecas, teatros, parques infantis, dispensários médicos e outros edifícios com usos distintos. Neste trabalho optou-se por destacar do conjunto produzido pela $\mathrm{CE}$ os edifícios escolares, pois assim é possível traçar um quadro comparativo e analítico das transformações que envolvem esse tipo de construção entre os anos de 1934 e 1962. Os parques infantis não foram incluídos por se tratarem de edificações únicas e que não fazem parte da trajetória definida nesta pesquisa, a de edifícios destinados a escolas. Os parques infantis possuem uma configuração arquitetônica e urbana tão diferente que não seria possível compará-la com edifícios produzidos antes da década de 1940. Essa Comissão teve nos seus quadros, desde o início, a presença ativa do arquiteto carioca Hélio de Queiroz Duarte (1906-1989), formado pela Escola de Belas Artes do Rio de Janeiro, e teve a participação de vários outros arquitetos e engenheiros. Foi Duarte o responsável pelo estabelecimento das principais premissas que os partidos arquitetônicos realizados pela CE deveriam adotar, participando também do planejamento da rede escolar. Também foi responsável por convidar alguns dos arquitetos que atuariam na CE.

Foi o caso de Eduardo Corona, que fora convidado pelo arquiteto Abelardo de Souza para trabalhar em São Paulo, como assistente de Anhaia Melo, na Faculdade de Arquitetura e Urbanismo da Universidade de São Paulo, em 1949. Chegando a São Paulo, conheceu o sócio de Abelardo, Hélio Duarte, e logo se tornaram companheiros. Hélio, já atuando na CE, convidou Corona para lá trabalhar. Apesar de já ter seu próprio escritório, não tinha clientes em quantidade suficiente para se sustentar e aceitou o convite. Logo em seguida entrou na CE Oswaldo Corrêa Gonçalves, que se tornaria um dos mais produtivos autores de projeto do grupo. 
Dentro das definições estabelecidas por Duarte e por vários outros arquitetos estava a intenção de planejar a escolha da localização dos edifícios. A implantação de escolas na cidade tinha como critério em comum, nos discursos analisados, a distância entre o aluno e a escola em que deveria estudar. Em quase todos os textos e entrevistas, o critério de distância é usado como forma de dispor a edificação escolar na cidade. Em geral o raciocínio era de que a existência de uma escola deveria ser capaz de atrair um determinado número de crianças até um raio pré-determinado tendo como centro a própria escola. Esse raio variava de 1 a $2 \mathrm{~km}^{15}$ e não se limitava apenas a quantificar o número de alunos e a quantidade de salas de aula que a escola deveria ter.

As premissas definidas por Duarte deveriam também se enquadrar no programa de construção, que previa a realização de 100 escolas até 1954, ou seja, cerca de 20 por ano, o que incluía edifícios de usos complementares e eminentemente sociais (duas bibliotecas e parques infantis por ano), ampliando o seu alcance a toda a comunidade próxima. Foram construídas 68 escolas ao todo. Dentre os arquitetos e engenheiros que realizaram os projetos estavam Eduardo Corona e Roberto Goulart Tibau, ambos formados na Escola de Belas Artes, no Rio de Janeiro, Ernesto Roberto Carvalho Mange e Oswaldo Corrêa Gonçalves, formados na Escola Politécnica da Universidade de São Paulo. A intensa participação de arquitetos formados na capital federal explica a adoção, naqueles projetos, das soluções da arquitetura moderna tal como ela se expandiu na capital federal nas décadas de 1930 a 1950 (figura 19 a 21).

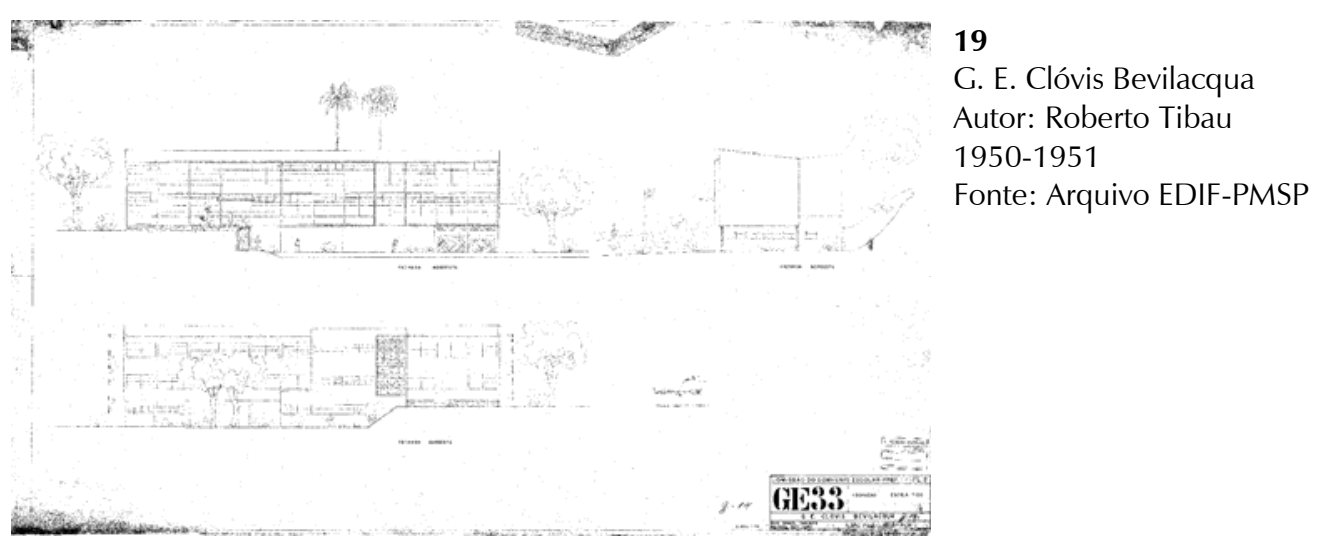

\footnotetext{
${ }^{15}$ Engenharia Municipal (11): 9, 1958, Habitat (4): 5, 1951, e entrevista com Eduardo Corona.
} 


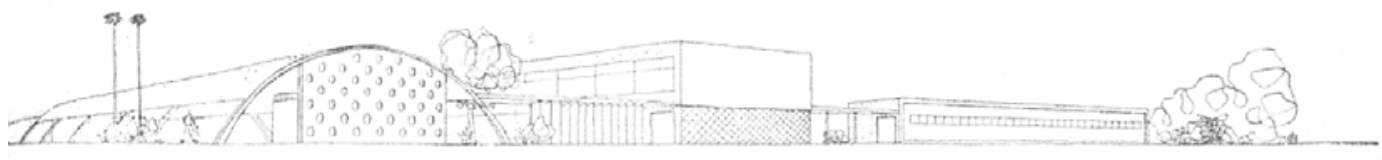

20

G. E. Reinaldo Ribeiro da Silva (G.E. 15)

Autor: Eduardo Corona

1950

Perspectiva

Fonte: Habitat (4): 39, 1951.

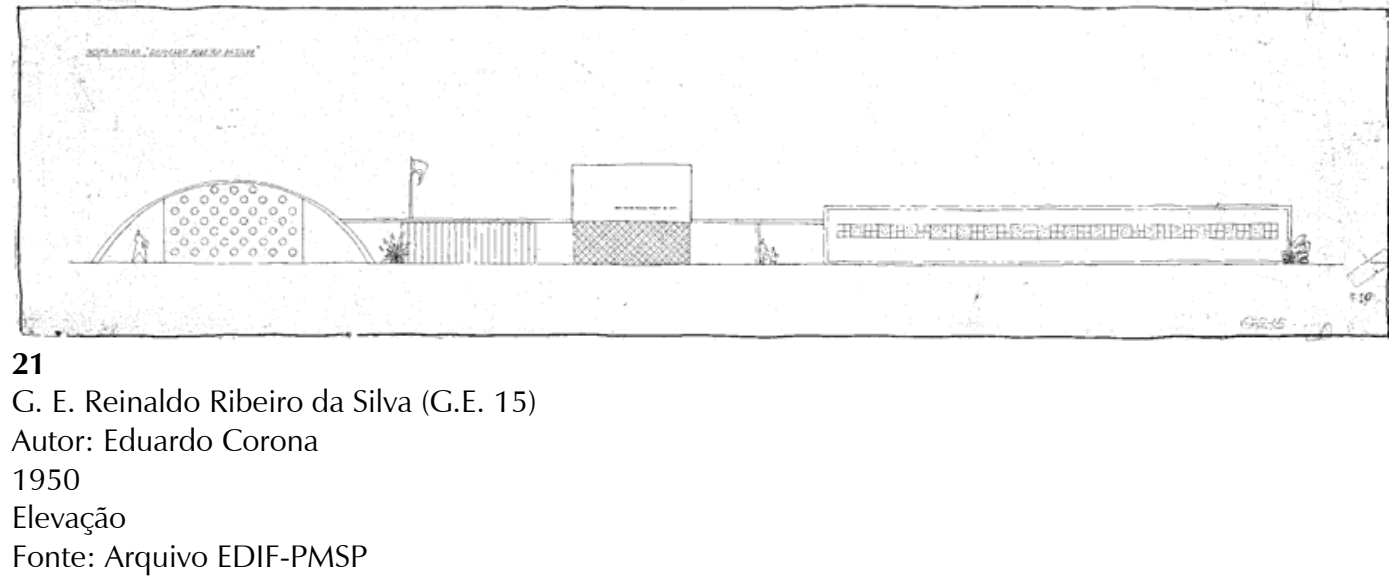

Na mesma época, por outro lado, arquitetos como João Batista Vilanova Artigas, Rino Levi e Oswaldo Bratke, entre outros, estavam atuando em escritórios próprios, e haviam feito alguns projetos de escolas, mas não haviam ainda enfrentado o programa da escola pública. À CE cabia planejar tudo o que fosse necessário para atender ao plano estipulado pelo Convênio: determinar os locais nos quais seriam construídas as escolas, agilizar o processo de elaboração dos projetos e da construção e satisfazer os prazos. Os arquitetos e engenheiros da Comissão procuravam materializar, em um desenho nitidamente influenciado pela expressiva arquitetura moderna produzida no Rio de Janeiro, as preocupações de Hélio Duarte, influenciado por Anísio Teixeira, buscando criar espaços que estivessem intimamente relacionados a novas formas de educação. Uma outra preocupação era a de criar escolas que agregassem um valor social que fosse além da sua função inicial - educar crianças - e tivessem um intenso relacionamento com a comunidade próxima, tornando-se uma espécie de centro social, de reunião da população. Para tanto foram planejados junto às escolas teatros, 
bibliotecas e outros equipamentos de uso comunitário. As figuras 22 e 23 mostram desenhos e plantas de mais uma escola projetada pela CE. O projeto, de autoria de Hélio Duarte é um dos poucos projetados no início de funcionamento da $\mathrm{CE}$ que não possui o galpão de recreação com cobertura exclusiva. Isso se deve ao terreno ter dimensões menores em comparação aos demais. A presença de um desenho influenciado pela arquitetura moderna produzida no Rio de Janeiro é acompanhada por um programa educacional muito diferenciado, e de alcance maior, em relação à década de 1930.

Apesar de haver um consenso em relação à importância do projeto arquitetônico em relação à educação, Duarte tinha consciência de seus limites:

Procurar no desenvolvimento de um plano arquitetônico razões últimas para uma melhoria educacional, parece-nos contrasenso. Arquitetura é precioso coadjuvante, mas não a base da educação. (DUARTE, 1956, p. 236)

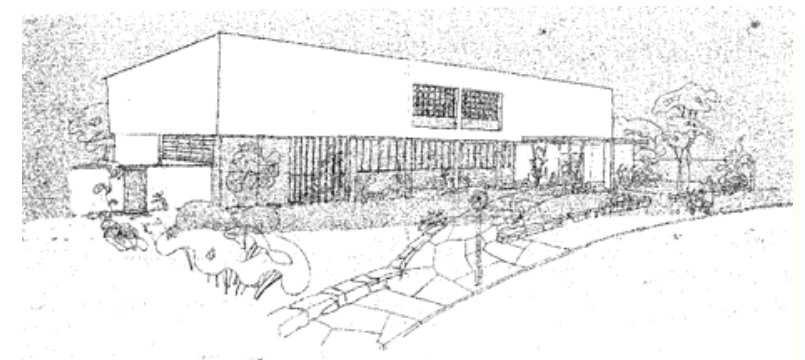

22

G. E. Brasílio Machado (G. E. 3)

Autor: Hélio de Queiroz Duarte

Anterior a 1951

Fonte: Arquivo EDIF-PMSP (fig. 22) e CORRÊA (1998), p. 30 (fig. 23)

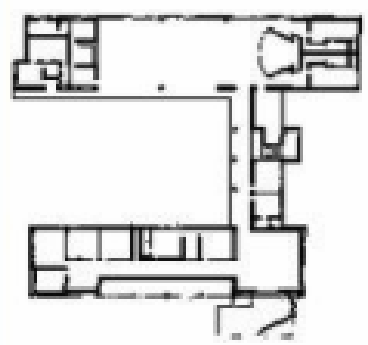

23

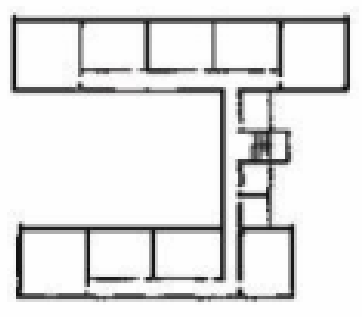

Apesar disso, os projetos nitidamente eram feitos tendo como referência a aplicação de conhecimentos provenientes dos campos científicos, técnicos e pedagógicos. Dessa maneira é possível afirmar que essa maneira de projetar pressupunha de fato que aqueles arquitetos acreditavam que a arquitetura também "educa”, pois esses espaços teriam sido projetados com pleno domínio, por parte de seus idealizadores, dos usos aos quais estariam destinados. A ciência, a técnica e a pedagogia garantiriam, na visão dos arquitetos e engenheiros, um controle total sobre a relação entre espaço e educação, e sobre o resultado desse binômio nas crianças e professores. A proposta aplicada na $\mathrm{CE}$, e que também carregava consigo o binômio arquitetura e educação, e que era bastante inovadora em relação ao passado próximo 
da arquitetura escolar em São Paulo, trazia a profunda influência das idéias do educador baiano Anísio Teixeira, com as quais Duarte travou conhecimento quando de sua estadia na Bahia. As idéias ousadas de Teixeira, baseadas em uma relação entre as chamadas escolasclasse (onde se ministravam as aulas como eram tradicionalmente conhecidas) e as escolasparque, abertas à comunidade (onde as crianças receberiam uma educação complementar, com músicas, atividades físicas e outras iniciativas) (DUARTE, 1973, p.26 e 39-40), influenciaram muito os conceitos presentes nos projetos realizados pela Comissão Executiva.

\subsection{As escolas da década de 1950: composição aditiva e as novas técnicas}

Os projetos realizados durante o segundo Convênio Escolar, celebrado entre o estado de São de Paulo e a prefeitura da capital paulista, após a Segunda Guerra Mundial, estão plenamente inseridos na arquitetura moderna, do modo pelo qual esta foi introduzida e desenvolvida dentro de São Paulo e do Rio de Janeiro. Mas a adoção dessa arquitetura está principalmente ligada ao fato de que os arquitetos autores dos projetos eram formados no Rio de Janeiro, com exceção de Ernesto Mange, engenheiro formado em São Paulo, mas que tinha conhecimento da arquitetura de Le Corbusier. Nessa arquitetura, adotou-se um processo de composição aditiva, baseada em estrutura independente. Na figura 24 está o projeto do G. E. Benedito Tolosa: os elementos que compõem o edifício são somados, unidos por uma circulação e configurados pelos espaços abertos da escola. O projeto cria uma série de vazios cuja configuração é mera conseqüência da implantação da edificação, sem um vínculo qualitativo direto com a geometria do terreno.

Das propostas arquitetônicas de Le Corbusier, algumas podem ser identificadas nos projetos de escolas. Porém, não há uma arquitetura, como ocorreu no edifício do Ministério da Educação e Saúde, que possa ser considerada exclusivamente fruto ou desenvolvimento direto dessa influência. As especificidades construtivas, as limitações impostas pela Comissão de Obras, os prazos exíguos e a existência de uma linguagem que era compartilhada com outros 
tipos de edifícios geraram, podemos afirmar, uma versão específica da arquitetura moderna. Essa versão não pode ser explicada somente tomando-se por princípio os referenciais europeus. Essa explicação torna-se mais plausível na medida em que permite reconhecer que alguns elementos arquitetônicos, como quebra-sóis, organização interna do programa, definição de circulações, e comprovadamente a criação de objetos especificamente projetados para as escolas, foram gerados pela reunião de profissionais em torno de um problema comum e localizado. A criação de objetos (luminárias, quebra-sóis, móveis, detalhes construtivos de todos os gêneros) pôde ser comprovada ao serem identificados, no arquivo da EDIF-PMSP, desenhos que contém esses projetos.

Um outro exemplo, que justifica essa versão local de arquitetura moderna, é que o uso da composição aditiva - que não era de forma alguma uma exclusividade dos arquitetos brasileiros - coincidia com a necessidade de um controle maior da insolação nas salas de aula e um controle sobre a volumetria final da edificação. A composição passa a ser um exercício em si, ainda que tentando resolver o problema proposto pela pedagogia e pela intenção de transformar a escola, como já ocorria desde 1936, em um espaço formador do cidadão e transformador da comunidade. Esses projetos, ainda que tivessem uma intenção plástica própria, definida pelos arquitetos e pelo seu desejo de criar volumes "soltos do solo" com uma riqueza volumétrica visível, destacando o conjunto de volumes, continham a pretensão de gerar uma "arquitetura que ensinasse", capaz de conter qualidades pedagógicas e de contribuir para o ensino de alguma maneira.

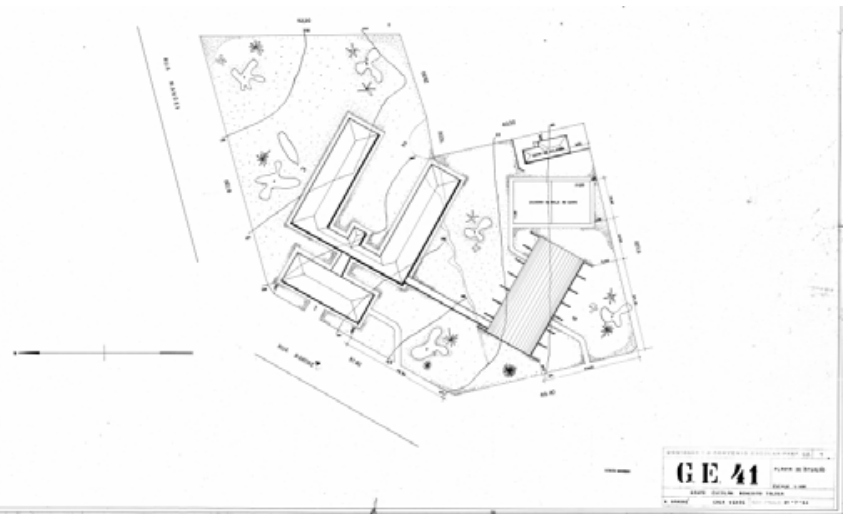

24

Grupo Escolar Benedito Tolosa (G.

E. 41)

1953

Fonte: Arquivo EDIF - PMSP 
Essa composição é visível em todos os projetos, com um claro desprezo pelo espaço externo. Este existia somente para permitir a existência dos volumes apoiados sobre esbeltas colunas ou sobre volumes de dimensão inferior aos que estivessem posicionados acima. A composição resultante traz a qualidade plástica, na qual se pretendia resolver problemas de outra ordem, criando uma unidade formal e pedagógica, no entender daqueles profissionais.

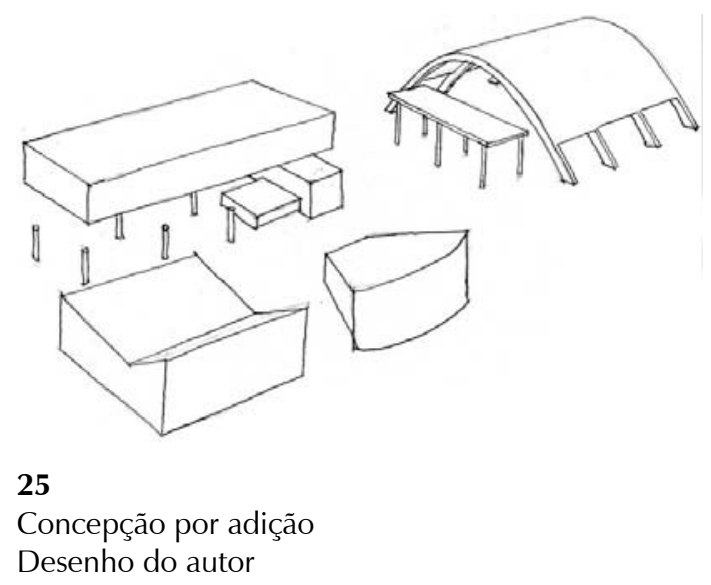

Esses projetos formados pela adição de elementos (figura 25) e volumes arquitetônicos razoavelmente pré-definidos não eram iguais, no que se refere à implantação e a sua volumetria e dimensões gerais. Porém, os elementos volumétricos que compunham o conjunto, esses sim, eram repetidos. Essa repetição facilitava muito o desenvolvimento dos projetos. Podemos afirmar que se tratava de um léxico arquitetônico formado por uma série de formas que, uma vez que tenham sido criadas e aplicadas em alguns primeiros projetos, seriam reutilizadas inúmeras vezes. Esses itens eram as salas de aula, cobertura do galpão, circulações verticais, palco com banheiros na sua parte posterior. Esse conjunto de formas era aplicado seguindo a organização que a escola deveria ter, em uma seqüência industrial, uma verdadeira linha de produção.

\subsection{A implantação e o vazio}

A implantação corrente era posicionar as salas de aula para norte ou nordeste, para prover as salas da maior e melhor insolação possível. No entanto havia a ocorrência de alterações na localização dos projetos, de acordo com o depoimento de Eduardo Corona: 
edifícios projetados para serem implantados em um determinado local eram transferidos para outro, sem as devidas adequações. A preocupação era de proporcionar a maior quantidade de luz natural que fosse possível.

Uma das conseqüências mais visíveis dessa implantação são as extensas áreas abertas que se situam entre o edifício e os limites do terreno. Nos projetos em que os lotes são relativamente menores, o projeto da edificação procura ocupar o espaço disponível da maneira mais eficiente para encaixar todo o programa da escola. Porém, quando o terreno possuía uma área maior, a implantação, em vários projetos, criava áreas abertas extensas, muitas das quais sem uma relação concreta entre o vazio nelas configurado e a edificação. Em depoimento Corona justificava a existência desses vazios afirmando que se tratava do resultado da aplicação de uma arquitetura mais funcionalista e eficiente, e que a solução para esses espaços era um projeto de paisagismo, o qual deveria ser executado pela Prefeitura, a qual, por sua vez, não implementava tais projetos. Essa prática era corrente entre inúmeros outros arquitetos na época. Os vazios tinham uma finalidade, além de permitir a melhor implantação do ponto de vista da insolação: era o de permitir que uma volumetria fosse configurada sem se comprometer com esse vazio, e ao mesmo tempo poder ser visível e destacar-se como objeto arquitetônico pousado no terreno. A leveza que os arquitetos pretendiam impor a seus projetos passava pelo piloti, pelos volumes lineares de salas de aula e corredores e também pelas áreas vazias extensas em torno das escolas. O vazio tornara-se parte imprescindível daqueles projetos: era o pano de fundo necessário para a arquitetura.

\subsection{A sistematização dos projetos: produção em série}

Para realizar os projetos durante o segundo Convênio Escolar, com a velocidade para construir o volume de escolas que era exigido pelo crescimento da cidade de São Paulo, faziase necessária uma sistematização do processo de projeto. O uso da composição aditiva e a repetição de elementos construtivos foram as soluções adotadas para resolver esse problema. 
A composição aditiva era uma solução interessante para desenvolver rapidamente o projeto. Uma vez escolhidos os volumes, dentro da linguagem adotada na CE, mais adequados para atender ao programa, eles eram implantados de acordo com a topografia e com uma circulação capaz de atender ao fluxo - tanto interno quanto externo - de crianças, funcionários e professores, e posicioná-los de acordo com a insolação, e às vezes, de acordo com a geometria do lote. Elimina-se o trabalho de criar novos volumes ou formas e testá-las ou ainda escolher novos sistemas construtivos para realizá-los. Um exemplo desse sistema é o próprio galpão de recreio das crianças: sua forma e sistema construtivo são geralmente os mesmos. Sua posição em relação à circulação principal também. Esse elemento, assim como os demais, uma vez definido, passa a fazer parte do léxico formal componível dos projetos modernos. Esse sistema também fazia com que o projeto carregasse as qualidades e defeitos de cada parte dessa linguagem arquitetônica.

A repetição de elementos construtivos também era uma solução comum. $\mathrm{O}$ uso de caixilhos, portas e demais materiais e elementos arquitetônicos também gerava uma velocidade maior dos projetos. Mas aqueles projetos faziam uso de uma prática ainda mais veloz: o uso das mesmas pranchas de desenho, simplesmente copiadas, contendo a caixilharia, portas, etc., para diferentes projetos. Mais do que uma sistematização, nesse caso não há escolha de alternativas dentro de um léxico, ou possibilidades de variações. O que ocorre é o uso de projetos idênticos, dentro de volumetrias que variavam na sua composição. A velocidade certamente não é a única explicação para a adoção desse sistema: o custo, muitas vezes citado pelos autores dos projetos, e a cultura construtiva das empresas envolvidas na construção das escolas também definiam a adoção de desenhos e soluções repetitivas.

\subsection{Arquitetura e indústria}

Usa-se o termo "industrial" aqui em dois sentidos. O primeiro se refere à própria forma de projetar os edifícios, que implicava em uma velocidade muito elevada de desenhos 
feitos em seqüência, como se pode verificar pela quantidade de projetos, feitos em pouco tempo. Essa forma de conceber o projeto é visível também nas plantas originais encontradas no arquivo da EDIF, da Prefeitura do Município de São Paulo, onde foi possível confirmar que era comum utilizar-se a mesma planta de que contém detalhamento de elementos construtivos - caixilharia, por exemplo - e, modificando-se apenas o carimbo, reutilizar aquele desenho em outro projeto.

O segundo sentido trata da própria pedagogia que alimentava a organização espacial dos projetos. A escola é organizada como uma indústria, em que a matéria prima entra na ponta do edifício e sai acabada no final do processo. O ensino seriado (o nome vem de série, semelhante a produção em série, em seqüência) pressupõe uma seqüência cronológica de sucessivos aprimoramentos das habilidades pessoais e acúmulo de conhecimento necessário para a passagem de uma série a outra, como um produto feito em série na indústria de transformação. Os projetos também possuem essa organização: há o edifício ou setor administrativo, que controla a produção; tem-se o edifício de produção propriamente dito, com as salas de aula alinhadas uma ao lado da outra, em blocos ou por unidade. O resultado é a organização de uma linha de produção industrial. Em conjunto adota-se a composição aditiva, denunciando no exterior a independência de usos de cada ambiente. É preciso ressaltar, porém, que nem todos os aspectos do edifício escolar produzido pela Comissão do Convênio Escolar podem ser descritas dessa forma. Como exemplo de uma indústria que possua as características aqui citadas, podemos destacar a fábrica da empresa de alimentos Duchen (1950), que foi demolida na década de 1990. O projeto é de Oscar Niemeyer e Hélio Uchoa, e localizava-se próximo à capital paulista (figura 26). Neste projeto foi utilizada a seqüência de pórticos estruturais aparentes que anos mais tarde seriam introduzidos nas construções escolares. A composição do conjunto arquitetônico segue a organização citada anteriormente. O conjunto é formado pela administração (bloco 1), pelo edifício da produção (bloco 2), restaurante (bloco 3), e laboratório (bloco 4), como está mostrado na figura 27. 

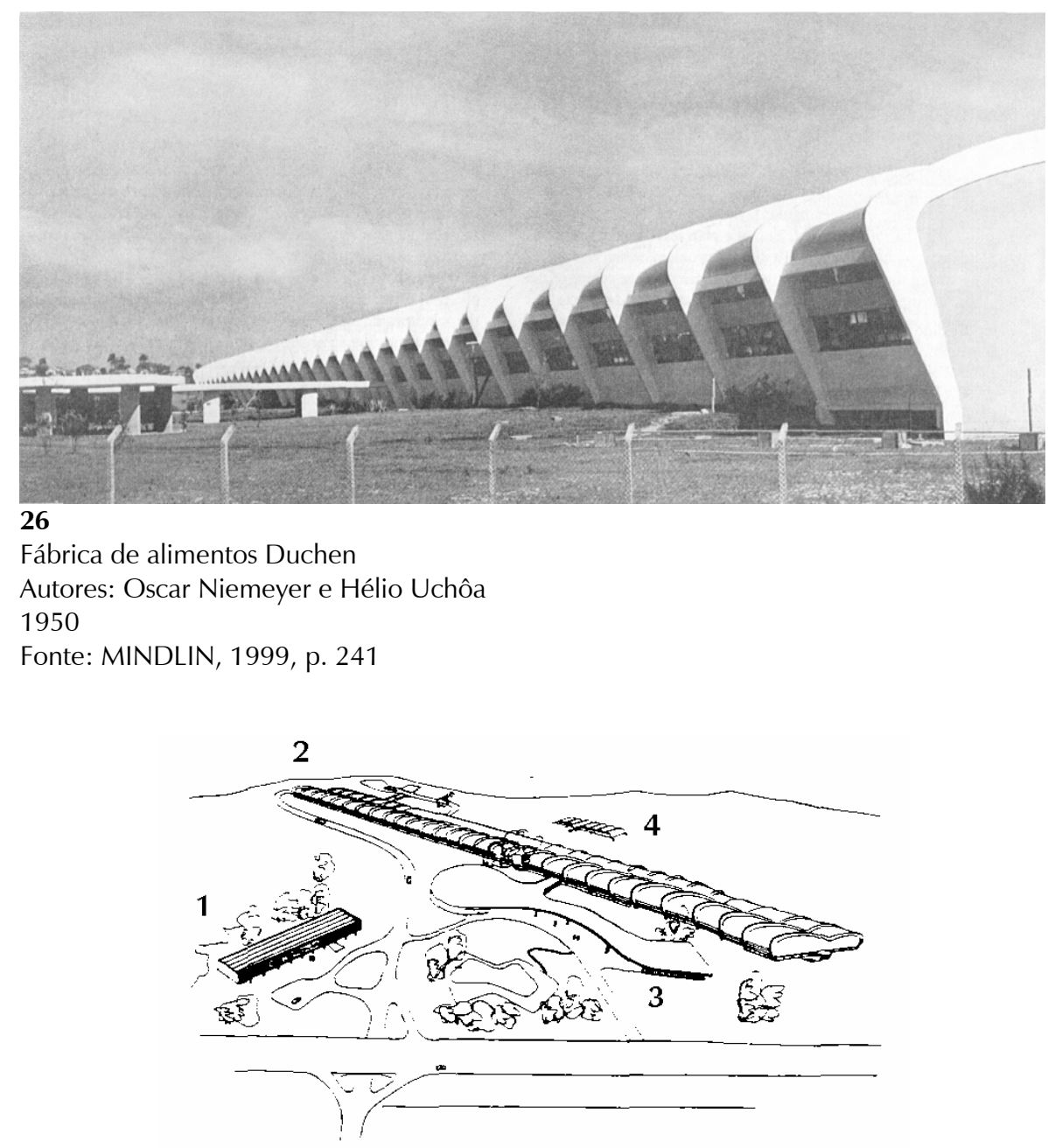

27

Fábrica de alimentos Duchen

Autores: Oscar Niemeyer e Hélio Uchôa

1950

Fonte: BOTEY, 1996, p. 59.

O terceiro aspecto é formal e resulta na construção de um edifício que também volumetricamente é muito semelhante a construções industriais. Essas características são: baixo gabarito, linearidade na fachada e no volume do edifício da produção (conjunto das salas de aula), separação do edifício que contém as salas de aula daquele que contém a administração, uso de uma linguagem arquitetônica baseada na repetição de janelas ao longo do edifício linear. Tome-se o gabarito para análise. Era plenamente possível construir escolas verticais, porém a disponibilidade de terrenos extensos permitia construir com altura total menor, reduzindo custos de construção e adequando o edifício a uma exigência que já existia desde a década de 1930: escolas para crianças devem ter a menor quantidade de pavimentos e escadas que for possível. Porém, até mesmo a justificativa do custo menor para construções 
horizontais também é uma idéia recorrente na construção industrial. Aquilo que poderia ser definido como uma coincidência decorrente de situações de origem distinta, mas de resultado construtivo semelhante, não pode ser considerado como tal. O funcionamento da escola também tinha em parte esse caráter industrial, com as salas de aula em série, e o fato de que foi a partir de projetos de indústria que uma parcela considerável das propostas da arquitetura moderna se desenvolveu no início do século XX.

Pretende-se com isso afirmar que as escolas produzidas no período possuem dois aspectos fortemente vinculados à arquitetura da indústria de transformação: o primeiro é a aparência externa, que lembra com freqüência edifícios industriais, pelas razões expostas acima, e o segundo é a própria organização da escola e que gera a aparência citada anteriormente. Resta perguntar-se sobre a origem dessa forma de projetar: se ela vem da indústria ou se é uma forma de projetar comum a inúmeros programas. Não é preciso lembrar que a arquitetura moderna, tal como foi elaborada na Europa a partir da década de 1920 e 1930 está umbilicalmente vinculada à máquina e à industria. Essa relação entre arquitetura e indústria, tal como foi desenvolvida no Rio de Janeiro e, por conseguinte, em outras regiões do país, foi entendida por Maxwell Fry - crítico contundente dessa relação - com otimismo, ao analisar o encontro de Le Corbusier com os arquitetos brasileiros e a sua contribuição feita no Brasil para elucidar essa relação:

O seu encontro com Lúcio Costa e Oscar Niemeyer, do qual o consagrado edifício do Ministério da Educação, com seu caráter tropical tão definido, foi o produto direto, encorajou uma escola de arquitetos, artistas e paisagistas a criar uma fusão da arte e habilidades nativas com o racionalismo da arquitetura moderna de base européia, que atribuiu forma e coerência às aspirações de uma nação ainda em processo de formação. Pareceu ao mundo que o Brasil de repente assumira um caráter que até então não lhe era associado, acentuando a verdade da afirmação de que a aplicação verdadeira da arquitetura é atribuir forma e significado ao que deveria ser a vida; neste caso, apontar para um destino possível. (FRY, 1976, pp. 169-170)

É preciso ainda considerar que naquele momento é no Estado que se encontram os meios de produção dos projetos, mas não necessariamente o ambiente no qual se formularam as teorias que alimentaram esses mesmos projetos. Após 1954, ano em que a Comissão 
modifica radicalmente a qualidade e as diretrizes dos projetos, foram construídos os chamados “galpões provisórios”, construções muito simples, de baixo custo, em geral de madeira, e de pouca durabilidade. Em 1953, com a mudança dos quadros da própria Comissão, já se delineava essa mudança de direção, com uma visível redução da qualidade das construções. Justificava-se essa atitude pela idéia de economia, que presidia a mentalidade dos engenheiros participantes do Convênio. A Comissão Executiva do Convênio Escolar realizou aproximadamente 70 edifícios para escolas, 500 galpões provisórios, 30 bibliotecas populares, 90 "recantos infantis" e 20 "parques infantis", entre os anos de 1949 a 1958. O Convênio Escolar encerra-se em dezembro de $1954^{16}$.

Abaixo estão colocados os edifícios que foram construídos durante a vigência do Convênio Escolar. A ordem numérica corresponde aproximadamente a uma seqüência cronológica de realização dos projetos.

Tabela 3 - Listagem dos projetos realizados entre 1948 e 1959

\begin{tabular}{|c|c|c|}
\hline Numeração & Nome da escola & $\begin{array}{l}\text { Data. Autor(es) do projeto e outras } \\
\text { informações }\end{array}$ \\
\hline G.E.1 & $\begin{array}{l}\text { G. E. Prof. João M. Boanova (Vila } \\
\text { Leopoldina) }\end{array}$ & 13.07.1949. Hélio Duarte \\
\hline G.E.2 & G. E. Prudente de Moraes & $\begin{array}{l}21.09 .1953 \text { (esta data é do projeto do galpão). } \\
\text { Hélio Duarte. } \\
\text { Execução: Sociedade Construtora Brasileira } \\
\text { Ltda. }\end{array}$ \\
\hline G.E.3 & G. E. Brasílio Machado & $\begin{array}{l}\text { Não foram encontradas datas de projeto nas } \\
\text { pranchas analisadas, mas o projeto é anterior a } \\
\text { 1951. Hélio Duarte }\end{array}$ \\
\hline G.E. 4 & G. E. Guilherme Kuhlmann & 25.04.1949. Autor não identificado \\
\hline G.E. 5 & G. E. Pedro Alexandrino & $\begin{array}{l}20.12 .1950 \text { (data de modificativo). Autor não } \\
\text { identificado }\end{array}$ \\
\hline G.E. 6 & G. E. Toledo Barbosa & 26.12.1949. Autor não identificado \\
\hline G.E. 7 & G. E. Pandiá Calógeras & 31.05.1949. 03.06.1949. Hélio Duarte. \\
\hline G.E. 8 & $\begin{array}{l}\text { G. E. Almirante Barroso (Vila } \\
\text { Jabaquara) }\end{array}$ & 24.05.1949. Hélio Duarte. \\
\hline G.E. 9 & G. E. Vila Gustavo & $\begin{array}{l}\text { 03.06.1949. Há dois projetos diferentes com } \\
\text { essa numeração e com a mesma localização de } \\
\text { rua e bairro. Um deles tem o nome do arquiteto } \\
\text { Hélio Duarte inscrito nele. O projeto final é de } \\
\text { sua autoria. }\end{array}$ \\
\hline G.E. 10 & $\begin{array}{l}\text { G. E. Romeu de Morais (Vila } \\
\text { Ipojuca) }\end{array}$ & $\begin{array}{l}\text { 28.12.1949, com retificação em } 17.05 \text { e } 12.07 \\
\text { de 1950. Oswaldo Corrêa Gonçalves. }\end{array}$ \\
\hline
\end{tabular}

${ }^{16}$ Cf. JULIÃO (1956), p. 17. 


\begin{tabular}{|c|c|c|}
\hline G.E. 11 & G. E. José Carlos Dias (Vila Baruel) & 13.08.1949. Hélio Duarte. \\
\hline G.E. 12 & G. E. Vila Campo Grande & 15.10.1949. Autor não identificado \\
\hline G.E. 13 & G. E. Orville Derby & $\begin{array}{l}\text { 09.11.1949. Hélio Duarte. } \\
\text { Execução: Sociedade de Engenharia } \\
\text { Politécnica Ltda. }\end{array}$ \\
\hline G.E. 14 & G. E. Cezar Martinez & $\begin{array}{l}\text { 15.12.1950 (data do modificativo). Hélio } \\
\text { Duarte. }\end{array}$ \\
\hline G.E. 15 & $\begin{array}{l}\text { G. E. Reinaldo Ribeiro da Silva } \\
\text { (Vila Anastácio) }\end{array}$ & 13.03.1950. Eduardo Corona \\
\hline G.E. 16 & G. E. Monsenhor Passalaqua & $\begin{array}{l}\text { Sem data. Não é possível confirmar se a } \\
\text { ampliação indicada em planta foi feita durante } \\
\text { o Convênio Escolar, pois não há indicações } \\
\text { nesse sentido. }\end{array}$ \\
\hline G.E. 17 & $\begin{array}{l}\text { G. E. Murtinho Nobre (Vila } \\
\text { Monumento) }\end{array}$ & $\begin{array}{l}\text { 05.01.1950. 04.12.1950 (modificação no palco } \\
\text { do galpão). Hélio Duarte. }\end{array}$ \\
\hline G.E. 18 & G. E. Visconde de Taunay & $\begin{array}{l}\text { 17.01.1950. Hélio Duarte. } \\
\text { Execução: Sociedade de Engenharia } \\
\text { Politécnica Ltda. }\end{array}$ \\
\hline G.E. 19 & G. E. Erasmo Braga (Tatuapé) & $\begin{array}{l}14.10 .1950 \text { (segundo a planta esta data é do } \\
\text { projeto modificado). Eduardo Corona. }\end{array}$ \\
\hline G.E. 20 & $\begin{array}{l}\text { G. E. Visconde de Inhaúma } \\
\text { (Mandaqui) }\end{array}$ & $\begin{array}{l}\text { 24.02.1950. 26.09.1950,27.10.1950 e } \\
\text { 14.11.1950 (datas da primeira ampliação). A } \\
\text { segunda ampliação é datada de 10.12.1953. O } \\
\text { autor é Oswaldo Corrêa Gonçalves (não foi } \\
\text { possível confirmar se do projeto ou da } \\
\text { ampliação). A segunda ampliação é da autoria } \\
\text { de Juvenal Waetge Junior. }\end{array}$ \\
\hline G.E. 21 & G. E. Pedro Taques & $\begin{array}{l}\text { 22.03.1950. Retificações em } 10.11 .1950 \text { e } \\
\text { 13.12.1950. Contém a assinatura de Oswaldo } \\
\text { Corrêa Gonçalves }\end{array}$ \\
\hline G.E. 22 & G. E. Barão H. de Mello & $\begin{array}{l}\text { Não há data no projeto, porém o levantamento } \\
\text { topográfico feito especificamente para esta } \\
\text { escola está datado de } 15.09 .1947 \text {. Autor não } \\
\text { identificado }\end{array}$ \\
\hline G.E. 23 & G. E. Carlos Escobar & $\begin{array}{l}27.04 .1950 . \text { Retificado em } 24.10 .1950 . \\
\text { Contém a assinatura de Oswaldo Corrêa } \\
\text { Gonçalves }\end{array}$ \\
\hline G.E. 24 & G. E. Alfredo Bresser & $\begin{array}{l}\text { 17.05.1950. Há a indicação de modificativo } \\
\text { datado de } 16.10 .1950 \text {. Autor não identificado }\end{array}$ \\
\hline G.E. 25 & G. E. Canuto do Val & $\begin{array}{l}\text { 03.07.1950. Contém a data de } 17.06 .1950 \text { na } \\
\text { planta de detalhes de esquadrias de ferro e } \\
\text { retificação em } 29.12 .1950 \text {. Oswaldo Corrêa } \\
\text { Gonçalves }\end{array}$ \\
\hline G.E. 26 & G. E. Joaquim Nabuco & $\begin{array}{l}25.07 .1950 \text {, com modificação em } 14.11 .1950 \text { e } \\
\text { ampliação em 15.09.1955. Ampliação de } \\
\text { autoria de Rubens F. Azevedo. }\end{array}$ \\
\hline G.E. 27 & G. E. Pedro Voss & $\begin{array}{l}\text { 01.08.1950 e } 14.08 .1950 \text {. Ernesto Mange. } \\
\text { Execução: Sociedade de Engenharia } \\
\text { Politécnica Ltda. }\end{array}$ \\
\hline G.E. 28 & G. E. Bernardo Rodrigues Nogueira & $\begin{array}{l}\text { 30.05.1951, 14.11.1951 e ampliação em } \\
\text { 25.08.1955. Autor não identificado }\end{array}$ \\
\hline G.E. 29 & G. E. Vila Nova Cachoeirinha & 09.09.1950. Autor não identificado \\
\hline G.E. 30 & G. E. João Teodoro & 31.10.1950. Autor não identificado \\
\hline G.E. 31 & G. E. General Antonio Sampaio & $\begin{array}{l}\text { 17.10.1950, com modificações em 12.08.1952. } \\
\text { Autor não identificado }\end{array}$ \\
\hline
\end{tabular}


24.02.1956 (Rubens F. Azevedo) e em 07.06.1957 (Roberto Tibau). Roberto Tibau

\begin{tabular}{ll}
\hline G.E. 33 & G. E. Clóvis Bevilacqua \\
\hline G.E. 34 & G. E. Couto Magalhães \\
\hline G.E. 35 & $\begin{array}{l}\text { G. E. República do Paraguai (Vila } \\
\text { Prudente) }\end{array}$ \\
\hline G.E. 36 & G. E. Frei Gaspar da Madre de Deus \\
\hline G.E. 38 & $\begin{array}{l}\text { G. E. Gabriel Ortiz (E.N.G.E } \\
\text { Domingos Faustino Sarmiento) }\end{array}$ \\
\hline G.E. 39 & E. A. Água Branca (E. A. 1) \\
\hline G.E. 41 & G. E. Benedito Tolosa
\end{tabular}
10.01.1950 e 06.03.1951. Roberto Tibau Sem data. Autor não identificado 29.10.1951. Oswaldo Corrêa Gonçalves

5.12.1950. Autor não identificado 10.01.1950. Ernesto Roberto Carvalho Mange 02.09.1950. Roberto Tibau 07.04 e 31.07.1953. Há o carimbo do desenhista Benito Mangini, mas o autor do projeto não foi identificado

\begin{tabular}{|c|c|c|}
\hline G.E. 42 & G. E. José Bonifácio & Sem data. Autor não identificado \\
\hline G.E. 43 & G. E. Engenheiro Goulart & 12.01.1953. Autor não identificado \\
\hline G.E. 44 & G. E. Aristides de Castro & 07.04.1951. Autor não identificado \\
\hline G.E. 45 & G. E. Taipas (Jaraguá) & 12.04.1951. Autor não identificado \\
\hline G.E. 46 & G. E. Zalina Rolim (Guaiauna) & 21.01.1954. Autor não identificado \\
\hline G.E. 47 & G. E. Nelson Fernandes & $\begin{array}{l}\text { 02.07.1951 e 04.07.1951. Autor não } \\
\text { identificado }\end{array}$ \\
\hline G.E. 48 & G. E. Paulo Setubal & 02, 05 e 07.06.1952. Autor não identificado \\
\hline G.E. 49 & G. E. Portugal & 13.11.1951. Eduardo Corona \\
\hline G.E. 50 & G. E. Estação XV de Novembro & 18.12.1951. Roberto Tibau \\
\hline G.E. 51 & G. E. Vila Mangalot & $\begin{array}{l}\text { 04.02.1952 A única data marcada foi } \\
\text { encontrada na folha de } \mathrm{n}^{\circ} .10 \text {. Autor não } \\
\text { identificado }\end{array}$ \\
\hline G.E. 52 & $\begin{array}{l}\text { Escola para o Serviço Social de } \\
\text { Menores }\end{array}$ & 04.05.1952 e 14.05.1952. Roberto Tibau \\
\hline G.E. 53 & G. E. Arthur Saboya (Vila Vera) & 30.06.1952. Roberto Tibau. \\
\hline G.E. 54 & $\begin{array}{l}\text { G. E. Tomáz Galhardo (Vila } \\
\text { Romana) }\end{array}$ & 01.10.1952. Juvenal Waetge Jr. \\
\hline G.E. 55 & G. E. Júlio Pestana (Jaçanã) & 28 e 29.08.1952. Autor não identificado \\
\hline G.E. 56 & G. E. São João Clímaco & $\begin{array}{l}\text { 12.08.1952 e } 30.07 .1952 \text {. Autor não } \\
\text { identificado }\end{array}$ \\
\hline G.E. 57 & G. E. Aclimação & Sem data. Autor não identificado \\
\hline G.E. 58 & G. E. Parque Edu Chaves & 29.09.1952. Eduardo Corona \\
\hline G.E. 59 & $\begin{array}{l}\text { G. E. Deputado Pedro Costa (Vila } \\
\text { Izolina) }\end{array}$ & 15.10.1952. Autor não identificado \\
\hline G.E. 60 & G. E. Julio Ribeiro & $\begin{array}{l}\text { O arquiteto Roberto G. Tibau fez o projeto de } \\
\text { ajardinamento em 16/05/1957. }\end{array}$ \\
\hline G.E. 60 & G. E. Vila Moraes & $\begin{array}{l}\text { 11.08.1954, 15.10.1952, 19.07.1954. Roberto } \\
\text { Tibau }\end{array}$ \\
\hline G.E. 61 & G. E. Canindé & 17.11.1952. e 02.07.1954 A. C. Pitombo \\
\hline G.E. 63 & G. E. Vila Palmeiras & $\begin{array}{l}\text { 1952. Aluísio Rocha Leão. } \\
\text { Execução: Construtora Cosmos Ltda. }\end{array}$ \\
\hline G.E. 64 & G. E. Vila Sonia & Sem data. Juvenal Waetge Junior \\
\hline G.E. 65 & G. E. Perus & 26.01.1953. Roberto Tibau \\
\hline G.E. 66 & G. E. Arnaldo Barreto & 25.02.1953. Juvenal Waetge Junior \\
\hline G.E. 67 & (G.R. 1) Alberto Torres ${ }^{17}$ & $\begin{array}{l}\text { 16.11.1951. Modificativo em 27.06.1952. } \\
\text { Roberto Tibau }\end{array}$ \\
\hline G.E. 68 & G. E. Cel. Domingos Ferreira & 20.08.1953. Paulo J. R. Rosa \\
\hline G.E. 69 & G. E. Pedreira do Rio Grande & $06.04,12.04,06.10,10.09,28.08$ de 1957. \\
\hline
\end{tabular}

${ }^{17}$ Uma rara imagem da maquete desse Grupo Rural (G.R.) pode ser encontrada na revista Engenharia Municipal (1): 17, out. 1955. 


\begin{tabular}{|c|c|c|}
\hline & & Roberto Tibau \\
\hline G.E. 71 & G. E. Campo Belo & Aluísio Rocha Leão \\
\hline G.E. 72 & G. E. Paulo Eiró & $\begin{array}{l}\text { O levantamento é de } 10.08 .1948 \text {. O projeto } \\
\text { novo não tem data. Reformas: Roberto Tibau e } \\
\text { Juvenal Waetge Junior }\end{array}$ \\
\hline G.E. 73 & G. E. Mirandópolis & 21.09.1953. Autor não identificado \\
\hline G.E. 74 & G. E. Vila Cristianópolis & 20.10.1955. José Augusto de Barros Arruda \\
\hline G.E. 76 & G. E. Vila Maria Alta & $\begin{array}{l}\text { Anteprojeto: } 22.03 .1957 \text { e projeto datado de } \\
22,23 \text { e } 30.01 .1958 \text { e } 12.03 .1958 \text {. Roberto } \\
\text { Tibau }\end{array}$ \\
\hline G.E. 79 & G. E. Vila Ema & $\begin{array}{l}\text { 14.10.1954. Paulo J. R. Rosa. } \\
\text { Execução: engenheiro Jorge Proushan }\end{array}$ \\
\hline G.E. 81 & G. E. Jardim São Paulo & 28.12.1954. A. C. Pitombo \\
\hline G.E. 84 & G. E. Raul Fonseca & Sem data. Paulo J. R. Rosa \\
\hline G.E. 86 & G. E. Cangaíba & Rubens C. M. Cardieri \\
\hline G.E. 87 & G. E. Frederico Steidel & $\begin{array}{l}\text { Planta de locação é de } 28.05 .1949 \text {. Outras } \\
\text { plantas de } 27.06 \text { e } 15.07 \text { de } 1949 \text {. Autores do } \\
\text { projeto: Ferreira Fanuele e Barreto } \\
\text { Engenheiros Arquitetos. }\end{array}$ \\
\hline G.E. 89 & G. E. Jardim Penha & 03.04 .1956$. \\
\hline G.E. 91 & G. E. José Escobar & $\begin{array}{l}\text { O original tem características Art Decó e a } \\
\text { reforma tenta manter a mesma linguagem. } \\
\text { Reforma: } 16.01 .1953\end{array}$ \\
\hline G.E. 93 & G. E. Arthur Guimarães & \\
\hline G.E. 94 & G. E. Prof. Theodoro Moraes & \\
\hline G.E. 98 & G. E. Antônio Firmino Proença & $\begin{array}{l}\text { Sofreu acréscimo em 02.09.1954. José } \\
\text { Augusto de Barros Arruda }\end{array}$ \\
\hline G.E. 99 & G. E. do Piquery & 13.05.1954. Autor não identificado \\
\hline- & Colégio Estadual de São Paulo ${ }^{18}$ & $\begin{array}{l}\text { 1958. Rubens C. M. Cardieri e Rubens F. } \\
\text { Azevedo. }\end{array}$ \\
\hline- & G. E. Jardim Ademar & 1955. Paulo J. Rodrigues Rosa \\
\hline- & G. E. Caxingui & 1955. Aluísio Rocha Leão \\
\hline- & Ginásio Santo Amaro & 1955. Roberto Goulart Tibau \\
\hline- & G. E. Otavio Mendes & 1952. Ernesto Roberto Carvalho Mange \\
\hline- & G. E. de Santo Amaro & 1955. Rubens C. M. Cardieiri \\
\hline- & G. E. Penha & $\begin{array}{l}\text { 1952. Eduardo Corona. } \\
\text { Execução: Zarzur \& Kogan Ltda. }\end{array}$ \\
\hline
\end{tabular}

No total havia pouco mais de seis arquitetos trabalhando dentro da área de projetos.

Todos os desenhos eram feitos por esses profissionais, com exceção dos projetos complementares (elétrica e hidráulica), para os quais eram contratados especialistas. Essas plantas de projetos complementares estão no arquivo da EDIF-PMSP, mas não foram consultadas para a elaboração desta tese. Nenhuma outra parte do projeto executivo era

\footnotetext{
${ }^{18}$ Apesar de ambos, projeto e construção, estarem a cargo da Comissão de Construções Escolares, que dera continuidade à Comissão Executiva do Convênio Escolar, a parceria nesse edifício foi feita com o Ministério da Educação. Nesse convênio o governo federal contribuiu com 1/3 do custo das obras. Esse convênio parece ter se limitado somente a esse edifício, pois na pesquisa não foram identificados outros projetos resultados de convênio entre a Prefeitura e o Ministério da Educação. Cf. Engenharia Municipal (10): 38, 1958.
} 
realizada fora da Comissão. Havia em paralelo uma Comissão de Obras, com engenheiros responsáveis pela fiscalização e realização das obras com construtoras privadas, contratadas pela Prefeitura por concorrência.

\subsection{A autonomia da Comissão Executiva e o planejamento escolar}

Para Presidente da Comissão Executiva do Convênio Escolar foi escolhido o engenheiro José Amadei, funcionário veterano dos quadros da Prefeitura e como arquiteto responsável pelos projetos, Hélio de Queiroz Duarte. Para o início dos trabalhos fica o destaque para a autonomia dos participantes da CE. Os autores do projeto conseguiram, dentro da Prefeitura, uma autonomia formidável para a realização dos projetos - o mesmo não se pode afirmar para a execução destes - e sempre com a anuência do engenheiro Amadei, que concordou, segundo os participantes da CE, com as propostas de Hélio Duarte. Essa convivência tranqüila dentro da $\mathrm{CE}$ foi fundamental para a implantação de um conjunto de idéias novas para a realização de projetos escolares, introduzidas exatamente por Hélio Duarte, bastante influenciado na época pelas do educador Anísio Teixeira para o ensino. Isso fez com que os programas de ensino e, portanto, das escolas, tivessem de ser alterados em relação ao que era feito até então no município de São Paulo.

A proposta de Hélio Duarte era transpor para o espaço do edifício as idéias desenvolvidas por Anísio Teixeira, e para isso ele desenvolveu um programa que passou a funcionar como referência para todos os edifícios projetados no Convênio. Certamente essas diretrizes não se referiam somente a edifícios voltados especificamente para escolas, pois na CE foram realizadas, como já foi dito, inúmeras outras edificações, com outras finalidades.

Os terrenos eram fornecidos pela Prefeitura, mas não foi possível identificar a origem da maioria deles. Alguns eram doações de políticos, que desejavam ter uma construção escolar feita sob seus auspícios. Outras, como se pôde verificar em plantas encontradas no arquivo da EDIF, eram terrenos desapropriados por decretos. Outros ainda eram doações de 
munícipes. A determinação do momento e local em que deveria ser feita uma escola não era prerrogativa exclusiva do Convênio Escolar nem da CE. A autonomia a que se referiu aqui é tão somente para o projeto das escolas em si.

Corona afirmou, em sua entrevista, que havia uma expectativa de posicionar as escolas de tal maneira que o percurso que as crianças deveriam fazer para chegar a elas deveria ser feito a pé, a distâncias não superiores a 400 metros. Em artigo publicado na revista Habitat n. 4, Hélio Duarte afirma que o posicionamento de uma escola na cidade de São Paulo deveria abranger um raio de 1500 metros. Essa abrangência, na proposta dele, não é apenas uma questão de distância, mas também um problema, ao que parece nos seus textos e de outros artigos na revista, freqüente e que era a possibilidade de usar a escola como um centro aglutinador de atividades da comunidade. Esse planejamento não se concretizou. A disposição das escolas na cidade seguia outros critérios.

A demanda indicada era de 48000 crianças em 1948. A velocidade de desenvolvimento dos projetos era formidável: a aplicação de tipologias pré-determinadas, o uso de implantações e disposições dos espaços pré-estabelecidas, a repetição de detalhamentos e de partes do programa, como o galpão, e até mesmo a simples reutilização de projetos quase idênticos em mais de um terreno, conferiam ao grupo uma capacidade de projetar bastante ampla. O mesmo não ocorria com a velocidade da construção. Segundo Corona, havia uma demora para fazer os prédios novos, pois a realização das concorrências públicas despedia um tempo incompatível com a necessidade da cidade. Para corroborar essa afirmação basta verificar-se que o próprio Hélio Duarte reconhecia a dificuldade de atender à demanda. Outros arquitetos participantes do Convênio e outros pesquisadores do assunto também reconhecem que o esforço de construção naquela época foi intenso, porém fícou aquém do que a metrópole em plena expansão demográfica exigia. Essa situação não deveria de forma alguma ser atribuída aos projetos em si, pois uma parte considerável dos sistemas construtivos neles utilizados eram de domínio das construtoras. A caixilharia também não era 
segredo para os executores, e nela os arquitetos também procuravam, como se pode ver nos desenhos, alguma sistematização, certamente com o intuito de construir mais rápido. Havia até, como já foi citado, o uso de estruturas pré-moldadas. A aplicação de coberturas com telhas de cimento-amianto também aumentava bastante a velocidade de execução em comparação aos telhados tradicionais. A simplicidade do acabamento e o uso de detalhes que se repetiam, ainda que não em todos os projetos, também eram uma maneira de aumentar a velocidade da obra. Essa velocidade não alcançou o que o "plano qüinqüenal" citado por Hélio Duarte, em seu artigo na revista Habitat n. 4, previa.

Cada arquiteto ficava incumbido de realizar um projeto, seja ele uma escola ou outra das edificações realizadas pela comissão do Convênio Escolar. Como se pode verificar nas plantas, havia a colaboração de desenhistas e engenheiros na realização dos desenhos, e possivelmente na definição dos projetos também, tal o clima de proximidade com que tudo parece ter ocorrido naquele ambiente de trabalho, com Hélio Duarte distribuindo as tarefas. A liberdade de projeto, segundo os depoimentos, era bastante grande. Apesar disso, as soluções das escolas se assemelham bastante. A implantação, com sua típica orientação e linearidade da seqüência das salas de aula, posicionadas somente de um lado do corredor caracteriza o “modus operandi” daquele grupo de profissionais. Essas soluções já estavam sendo aplicadas em grupos escolares desde a década de 1930, mas em muitos textos e depoimentos assumiu-se que essa seria uma contribuição dos profissionais ligados à CE.

\subsection{Os sistemas construtivos}

Os sistemas construtivos utilizados nas obras para executar os projetos desenvolvidos pelos arquitetos e engenheiros da $\mathrm{CE}$ eram o que havia de mais comum na época, ao que a pesquisa indica, devido à velocidade da construção, mas principalmente em função do custo. O próprio Eduardo Corona admitiu que esse foi um dos motivos do seu pedido de demissão em 1953. Ainda segundo ele, outro motivo era que o Convênio escolar já se encontrava na 
reta final, pelo prazo imposto, que era o ano de 1954. A preocupação de Corona com a qualidade dos materiais empregados nas construções parece ter sido compartilhada por outros participantes da $\mathrm{CE}$, pois em seu depoimento Corona afirma que a solicitação por materiais melhores era feita conjuntamente. Esse parece ter sido um ponto de discórdia constante dentro do Convênio Escolar. As relações entre a CE, encarregada dos projetos, e a Comissão de Obras, encarregada da execução dos projetos, ocorriam com alguns conflitos entre seus métodos de trabalho. Em certa ocasião, Corona propôs que as portas das salas de aula fossem pintadas com cores, ao que os engenheiros do próprio Convênio Escolar se opuseram com veemência. Ao final as portas foram envernizadas somente. O principal argumento era que com um custo menor por escola poder-se-ia fazer mais edificações, o que era no mínimo uma exigência sensata em função da enorme pressão para atender à crescente demanda de salas de aula. O papel dos engenheiros era fiscalizar e dirigir as obras, executadas por construtoras que participavam das concorrências públicas. Ainda segundo Corona, esses engenheiros não permitiam a presença de arquitetos na obra, principalmente, ao que tudo indicava, para evitar que esses mesmos arquitetos interferissem na execução com quaisquer tipos de observações ou alterações durante a execução do projeto que pudessem incorrer em alteração dos custos e, certamente, dos prazos.

Em face das condições em que os projetos deveriam ser feitos e executados, e também à transposição nada fácil do projeto para a obra, as escolas acabaram sendo feitas com sistemas construtivos bastante usuais e de custo mais baixo. A exceção fica a cargo da cobertura do "galpão de recreação", feita com arcos de concreto armado pré-moldados, cobertos com telhas de fibrocimento, o que se pode considerar como sendo uma verdadeira conquista tecnológica em uma construção que deveria primar pela simplicidade, aliada a um custo baixo e uso de materiais de baixa qualidade. Os arcos eram comprados pelas construtoras de empresas especializadas em sua execução. O uso de um sistema pré-moldado em uma escola de baixo custo parece ter sido conquista de Hélio Duarte e de sua influência 
junto à direção do Convênio Escolar. A principal questão levantada acerca do galpão era que ele era projetado para ser totalmente aberto, sem vedações laterais, exceto onde se localizava o palco. Essa situação gerava algumas limitações no seu uso em função das baixas temperaturas no inverno da época.

\subsection{As escolas da Comissão Executiva}

As escolas analisadas a seguir demonstram a intensa capacidade de produção de projetos por parte de um grupo pequeno de engenheiros e arquitetos, e um esforço sem comparações até então na história de São Paulo. Porém, não havia a possibilidade de alcançar em curto prazo a gigantesca demanda que não parava de aumentar. Exemplo maior desse impasse é a necessidade contínua, que ocorria em várias escolas, de ampliar o número de salas de aula, acontecendo em alguns casos de duplicar o número de salas. Apesar da limitação de tempo, as escolas produzidas pelos arquitetos e engenheiros da Comissão Executiva do Convênio escolar, liderados durante os primeiros anos por Duarte, contém projetos bem resolvidos.

A continuidade com o período analisado nos capítulos anteriores existe, ainda que não à primeira vista. As análises pretendem gerar um conhecimento que possa ser feito de maneira geral para o período em questão.

De uma maneira geral, a organização dos projetos de edifícios escolares assume uma descrição que lembra com intensidade o raciocínio biológico do texto da Carta de Atenas. A divisão em três "funções" (administrar, ensinar e recrear) em muito se assemelha com a hierarquia de zonas exclusivas proposta no famoso texto voltado para o urbanismo. Essa hierarquização dentro das escolas chegou a ser taxada de "inevitável" 19 . Essa relação e o uso do zoneamento funcionalista transparecem em artigos de Oswaldo Corrêa Gonçalves ${ }^{20}$, no qual ele analisa a presença das quatro funções da Carta de Atenas. Ele afirma que a disposição

\footnotetext{
${ }^{19}$ Acrópole (141): 234-236, jan. 1950.

${ }^{20} \mathrm{O}$ artigo é resultado de palestra proferida no Rotary Club e foi publicada nas revistas Habitat (24): 13, out. 1955 e Arquitetura e decoração (9): jan. fev. 1955
} 
das escolas na cidade é ainda feita ao acaso, apesar dele mesmo estar atuando na época em um órgão público cujos profissionais procuram afirmar o contrário, ou seja, que há alguma lógica na disposição das escolas dentro da cidade. Corrêa Gonçalves nitidamente defende os princípios da Carta. Então por que não aplicá-los dentro da escola? É o que ocorre de uma maneira geral, levando os projetos da CE e da Comissão de Construções Escolares a serem organizados em uma composição aditiva, cujos volumes são organizados nas três funções da escola. Alguns projetos modificam um pouco essa postura, mas não em toda a edificação, apenas reunindo em um volume no máximo dois grupos funcionais distintos.

Há também algumas marcas que definiam a aparência e o resultado formal das edificações:

a) o uso do telhado borboleta, no qual as diferentes águas das coberturas convergem para uma captação de águas pluviais situadas no meio do volume edificado ou no encontro de dois volumes distintos;

b) o uso, sempre que possível, do piloti;

c) as fachadas ora eram definidas por cobogós, ora por uma seqüência de janelas com os mais variados desenhos;

d) a estrutura tectônica quase sempre discreta não comparece na definição do desenho, com exceção do galpão coberto e de alguns projetos. É mais comum o volume dos blocos que compõem a escola serem definidos por planos lisos ou delimitados por cobogós e/ou janelas;

e) o ritmo de leitura das fachadas de cada um dos volumes é dado ora pelas aberturas e elementos complementares, como quebra-sol, ora pelo desenho da própria parede.

f) uso da composição aditiva por volume ou, quando esta não era viável pela dimensão ou topografia acentuada do terreno, um volume mais concentrado, mas ainda revelando partes independentes. 


\subsection{O mobiliário escolar}

O mobiliário escolar, que aparece nos projetos de escola como leiaute interno, demonstrando as possíveis formas de ocupação do espaço, principalmente das salas de aula, não comparece com freqüência nos artigos analisados e mesmo nos textos feitos por arquitetos que fizeram projetos de escolas. Os desenhos que aparecem nos projetos são em geral bastante simples, e tentam explicitar mais diretamente a relação entre o espaço proposto e a pedagogia que será nele aplicada. Sobre o projeto de móveis escolares foi encontrado um artigo, de autoria de L. A. Falcão Bauer ${ }^{21}$. A relação entre o mobiliário escolar, a organização destes dentro das salas de aula e a geometria dessas salas é por vezes diretamente visível e em outros momentos persiste uma independência entre ambos.

$\mathrm{Na}$ grande maioria dos casos a dimensão e a forma das salas pouco se modificaram desde a década de 1930. Por outro lado, a disposição dos móveis dentro da sala de aula foi objeto de estudo de pedagogos, como Montessori, e essas pesquisas influenciaram os arquitetos no desenho das salas de aula. Em algumas oportunidades foram feitas, no projeto da edificação escolar, uma ou mais salas de aula em que a forma do ambiente está diretamente relacionada à atividade que será exercida dentro dele. Nesses casos essas salas são de uso específico, ou seja, tem "a priori” uma única finalidade, o que possibilita ao arquiteto realizar um desenho aparentemente específico, procurando desenhar o espaço e a disposição dos móveis da maneira considerada mais adequada à realização das atividades a que o ambiente se destina. Essa especificidade quase biológica, ou seja, de tentar uma relação entre forma e função mais direta, ficou circunscrita a poucos ambientes dentro dos inúmeros projetos analisados neste trabalho, se compararmos a quantidade de escolas projetadas. Um desses exemplares é o projeto do Ginásio de Santana, da autoria do engenheiro Ernesto Mange. Nesse projeto $^{22}$ a forma da planta das salas se modifica criando uma disposição aparentemente mais adequada ao seu uso. De fato, modificar o ambiente cria outras

\footnotetext{
${ }^{21}$ Habitat (7): 21, 1952.

${ }^{22}$ Habitat (7): 24-25, 1952.
} 
possibilidades de ocupação: a pergunta que fica é se essa especialização formal é resultado de uma visão pedagógica ou de um problema acústico ou visual por parte dos alunos e dos professores. Ao que tudo indica, a idéia aqui presente de que essas edificações têm em geral um caráter industrial não é desvanecida ainda com essas alterações de salas específicas. Muito pelo contrário, essa solução, citada também no texto que apresenta o projeto do Ginásio de Santo Amaro (aqui identificado como G. E. Santo Amaro, da autoria de Roberto Tibau ${ }^{23}$ ), explica um desejo de especialização da formação do aluno, através de uma forte contribuição da arquitetura. Apesar do projeto do ambiente tentar adequar-se a um uso específico, o desejo de manter uma unidade formal do lado externo e no que se refere à volumetria, é muito mais intenso, como pode-se verificar em todos os projetos, do que qualquer iniciativa de identificar no projeto formas que destoem do conjunto plástico. Mesmo com a especialização pedagógica, a unidade plástica permanece como um determinante fundamental nos projetos. Essa atitude revela uma distância grande entre um discurso de cunho funcionalista, presente em textos que explicam as soluções adotadas nos projetos e a solução arquitetônica final adotada nos desenhos e nas obras. O resultado é que a aparência de edifício industrial é beneficiada com essa atitude, pois se houvesse uma resultante volumétrica mais intensa, gerada a partir das soluções de ambientes internos diferenciados, os edifícios escolares teriam um vínculo muito menor com a forma e a implantação de edifícios industriais, bem como de sua lógica interna, que é a da produção seriada em massa. O que ocorreu é que houve de fato a especialização na arquitetura das escolas públicas, ainda que emoldurada pela independência formal dos blocos que compõem o conjunto.

A especialização de salas de aula por disciplina foi aplicada em outros projetos. Identificou-se o ginásio de Santo Amaro, da autoria de Roberto Tibau. Havia salas de química, física, ciências e história, além dos demais ambientes que compunham o conjunto,

\footnotetext{
${ }^{23}$ Habitat (20): 12-13, jan. / fev. 1955.
} 
que tem dimensões consideráveis, incluindo uma área de atendimento com enfermaria, médico e dentista.

Essa especialização não tem um reflexo na aparência externa do edifício (figuras 28 a 30). Mantém-se a composição por adição de volumes, destacando-se o auditório com sua forma típica de planta em leque. Externamente as salas não refletem seus usos internos. Prevalece a idéia de unidade por bloco: cada volume possui uma característica formal que o individualiza, mas nele próprio não são aceitas partes independentes. Cada bloco é como um microcosmo submetido a uma resultante formal única. A construção, ao final, é a somatória de cada um desses microcosmos, e a aparência de edifício industrial se mantêm.
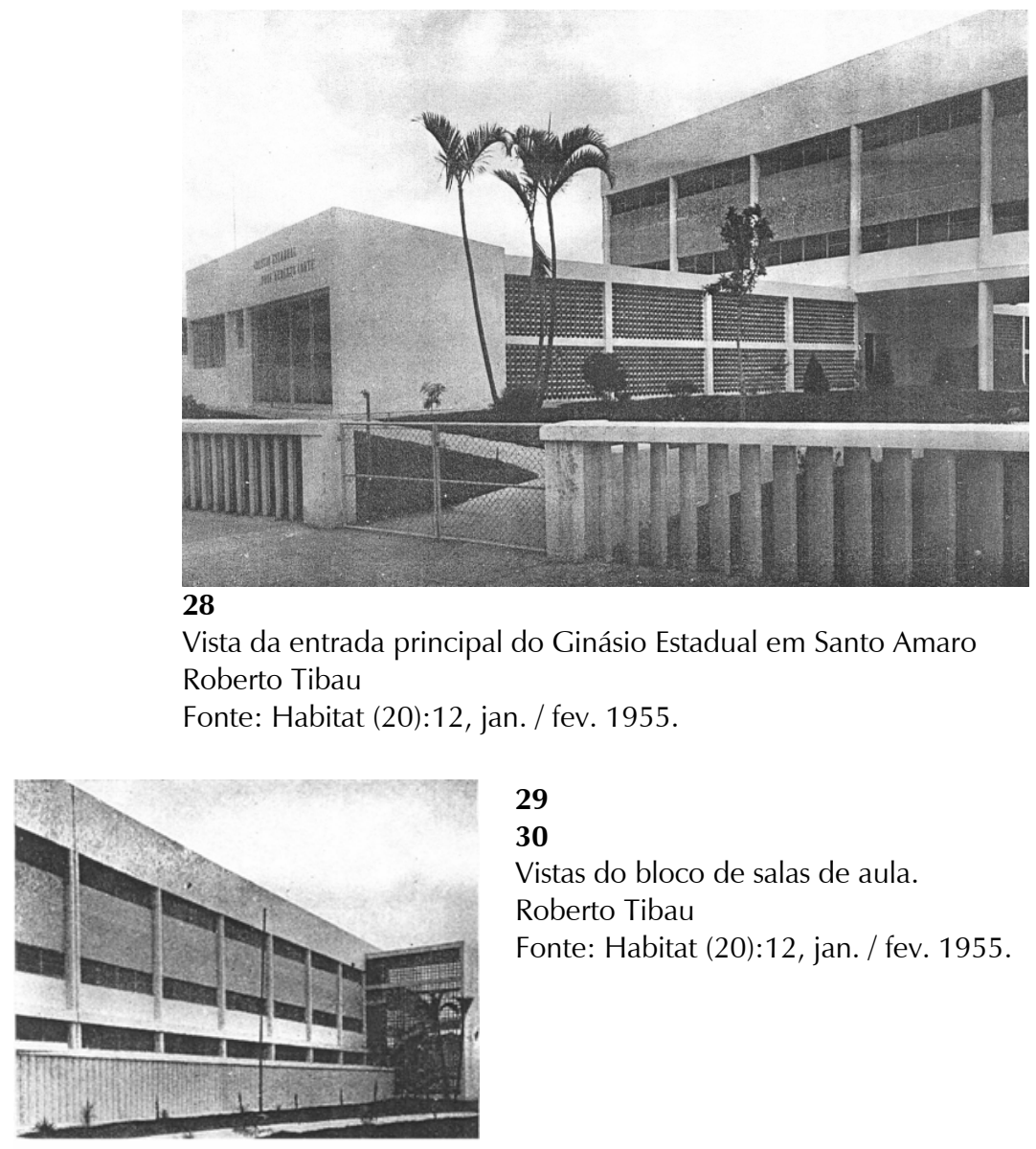

\section{9}

30

Vistas do bloco de salas de aula.

Roberto Tibau

Fonte: Habitat (20):12, jan. / fev. 1955.

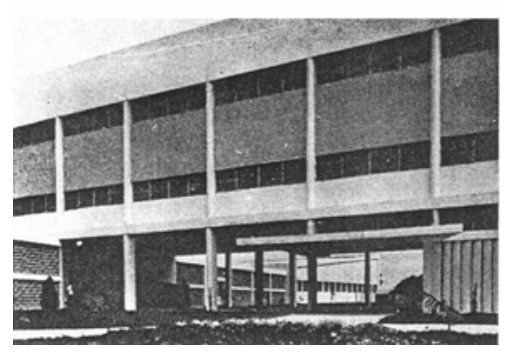




\subsection{Arquitetura, técnica e ciência}

No artigo intitulado "O problema escolar e a arquitetura" e que se tornou emblemático na divulgação das atividades da CE do Convênio Escolar, Hélio Duarte tenta estabelecer uma relação direta entre proposta pedagógica e arquitetura, justificando as soluções que nortearam sua contribuição dentro da CE (figura 31).

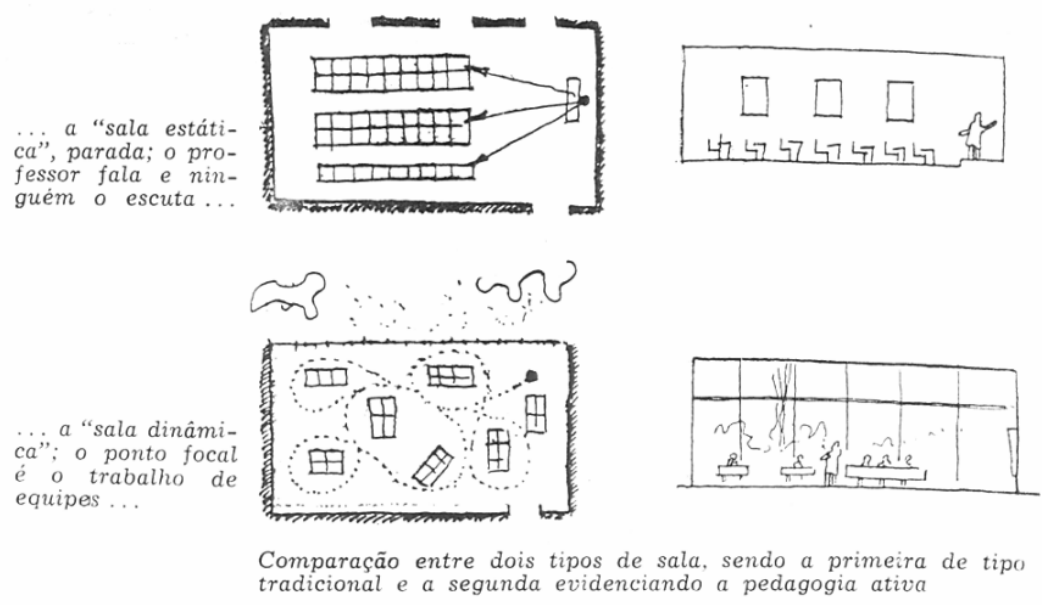

31

Desenho incluído no artigo "O problema escolar e a arquitetura, procurando evidenciar a contribuição da arquitetura para uma nova pedagogia.

Fonte: DUARTE, 1951, p. 6.

Essa forma de concepção de escolas será uma marca fundamental dos arquitetos vinculados à CE. Será comum encontrar projetos em que os arquitetos demonstram conhecer teorias da pedagogia e justificar, em texto ou com desenhos, a adoção de determinadas formas espaciais, materiais construtivos e dimensionamentos nas escolas públicas tendo como referência tais teorias.

No seu artigo “Arquitetura escolar”, Ernesto Mange faz uma descrição pormenorizada dos objetivos que ele acreditava serem os mais importantes para a construção do que ele denominou como sendo "arquitetura experimental". O texto procura descrever os aspectos quantitativos e qualitativos que deveriam ser utilizados para realizar um projeto arquitetônico com um nítido embasamento científico-matemático. No seu artigo, bastante revelador, e também na entrevista com ele realizada, estão os assuntos mais pertinentes: a pedagogia, a 
ambientação psíquica e bio-psicológica, os problemas térmicos e higiênicos. Por experimentação podemos deduzir que o autor se refere à prática científica, na qual é necessário utilizar algum método para determinar um objeto de análise e sobre ele aplicar ou dele extrair um conhecimento materialmente utilizável. Neste caso, o próprio autor indica algumas soluções arquitetônicas que poderiam solucionar os problemas que seriam identificados nos aspectos citados anteriormente. Como exemplo, descreve-se abaixo como a ambientação psicológica tem uma forma de ser solucionada matematicamente:

Como exemplo típico do fator arquitetônico de enorme valor na ambientação psicológica podemos citar a escala. [grifo do autor]. A escala dos "elementos" e do "todo" da obra deve subordinar-se a êsse imperativo. Advém, daí, dada a extensão dos programas, uma dificuldade séria. Devemos sempre ter em mente que a avaliação sensível dos volumes será feita pela criança em função do seu próprio volume. Assim para uma criança normal de $1,20 \mathrm{~m}$ de altura, com relação a um adulto médio, as sensações dos volumes estarão na relação de 3 para 1.

hc / ha $=1,20 / 1,70 \cong 0,7$

hc $=$ altura da criança

ha $=$ altura do adulto

$\mathrm{Vc} / \mathrm{Va} \cong(0,7)^{3} \cong 1 / 3$

$\mathrm{Vc}=$ volume da criança

$\mathrm{Va}=$ volume do adulto

Essas considerações levam à diminuição das alturas dos compartimentos e à tratamentos especiais das suas superfícies, visando harmonizar as dimensões funcionais dos volumes à escala da criança [grifo do autor]. Exagerando-se um pouco já foi dito; principia a estar bem para a criança quando começa a tornar-se ruim para o professor... ${ }^{24}$

O interesse de Mange em caracterizar a arquitetura moderna como aquela que deveria ser a mais adequada ao seu tempo, absorvendo as novas conquistas técnicas e científicas está exposta em artigo publicado na revista Politécnica:

Já na atualidade são inúmeros os exemplos de obras condenáveis, sob o prisma que ora nos interessa. Porque, sobretudo desde a metade do século XIX, a ciência e a técnica progrediram de forma extraordinária: portanto aumentou o acervo de conhecimentos acerca das relações "homem-ambiente" e novas técnicas de execução foram postas ao serviço do arquiteto. Natural seria que par e passo a arquitetura fosse se modificando no sentido de atender

\footnotetext{
${ }^{24}$ Acrópole (197): 211-213, mar. 1955.
} 
sempre à sua função essencial, com base nos novos conhecimentos e nas novas técnicas ${ }^{25}$.

A presença do conhecimento técnico e científico, das mais diversas áreas, é uma presença constante nas obras realizadas desde 1934 até a década de 1950, estendendo-se a questões relativas à funcionalidade, ao custo e à forma dos projetos. Mange elabora, no riquíssimo artigo acima citado, um gráfico que seria capaz de explicar a relação entre utilidade, custo, racionalidade e ciência na arquitetura (gráfico 2):

Consideremos a figura 20. - O eixo vertical é uma escala de utilidade, que representa a soma dos valores obtidos ao responder, às "funções específicas de proteção e utilidade". O eixo horizontal é uma escala de custos, mão de obra e materiais. As obras de arquitetura atendendo ao gráu de utilidade conseguido (escala, qualidade, etc.) e ao custo correspondente, dão origem às três curvas traçadas. $\mathrm{O}$ afastamento que há entre a curva da obra $100 \%$ racional e da obra moderna uma utilidade U2>U3. Evidentemente, se última não atinge e não deverá talvez atingir os caracteres de creação totalmente científica e racional [grifo meu]. O emprego de certos materiais mais caros e certo império da plástica provocam esse afastamento das duas curvas. Pelos motivos expostos atrás, a curva da arquitetura tradicional está evidentemente ainda mais afastada da curva racional ${ }^{26}$.

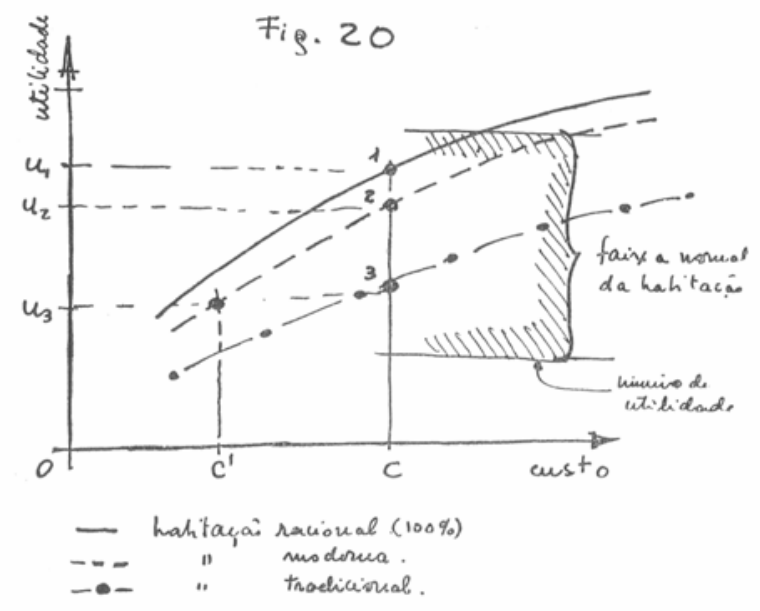

Gráfico 2

Relação entre utilidade e custo

Fonte: Separata da Revista Politécnica (155):15, out. 1949.

O texto trata da arquitetura em geral, estendendo-se aos projetos de escolas que ele fez, incluindo as escolas para o SENAI. Em depoimento obtido para esta pesquisa Mange revela também alguns dos cálculos que utilizava para realizar seus projetos. Sua crítica era que os projetos eram feitos sem um controle preciso das razões que determinam o desenho no

\footnotetext{
${ }^{25}$ Separata da Revista Politécnica (155):4, out. 1949.

${ }^{26}$ Separata da Revista Politécnica (155):15, out. 1949.
} 
projeto, como em uma janela. Sua preocupação com a aplicação de conhecimentos técnicocientíficos na arquitetura estava presente na entrevista que concedeu a esta pesquisa.

O arquiteto Aluísio Rocha Leão, em um projeto de escola primária para o Jóquei Clube de São Paulo $^{27}$, que não foi executado, faz uma importante relação entre autores da pedagogia moderna, como Jean Piaget, John Dewey e Celestin Freinet e a aplicação na arquitetura dessa escola. Essa maneira de descrever o projeto revela o forte vínculo que os arquitetos dessa geração - em especial os que projetavam escolas desde 1936 - procuravam estabelecer entre o conhecimento científico de diversas áreas e a arquitetura.

O estudo dos métodos pedagógicos e das suas aplicações no projeto arquitetônico seria objeto de um posterior artigo sobre o assunto. No momento citaremos os autores e os principais métodos estudados e indicaremos o local na presente escola onde se pode vêr sua aplicação: Claparéde: - Princípio de educação funcional 14 - 15 - 2023 - 24 - 26 - 28. John Dewey: «O ambiente escolar deve possuir meios que tornem possível a solicitação de atividades concretas» - 7 - 13 - $14-15$ - 20 - 23 - 2426 - 28. W. Lay: - Ambientes vivos - Cultivo das plantas, criação de animais etc. 14 15 - 20 - 21 - 22 - 23 - 26. Piaget: -- Casualidade mecânica - Arquivos museus, modelagem e carpintaria 11 - 13 - 15. EIlen Key: - 15 - 21 - 22. Ação da natureza sobre a criança. Plano Dalton: - Classes - laboratórios 10 15 - 16 - 17. Cousinet: - Estudo em equipe - Fichas 11 - 17. Freinet: Cinema - Biblioteca - jornal falado 7 - 13."28

A preocupação com a aplicação da técnica e suas razões científicas continua no texto:

As salas de aula por motivo de reflexão da luz são pintadas de branco exceto a parede que circunda o quadro negro, que é côr de laranja. Assim, a atenção do aluno é chamada (já também pela forma da sala) para o ponto onde se coloca o quadro negro, o qual na realidade não deve ser negro, mas sim verde policrônico, côr cientificamente estudada para esse fim." 29

Em outro momento a relação entre arquitetura e biologia é nítida:

Estudando o poder bactericida nos raios ultra-violetas verificamos que a face $\mathrm{NE}$ (depois da $\mathrm{N}$ ) é a mais aquinhoada em presença de raios $\mathrm{U}$. V. durante o decorrer do dia.

Considerando-se que o bacilo de Koch capsulado (que é resistente ao álcool e até ao ácido) morrem em 10 minutos de exposição aos ultra-violeta, vê-se logo a importância de se voltar as salas de aula para $\mathrm{N}$ ou NE." 30

\footnotetext{
${ }^{27} \mathrm{O}$ mesmo texto foi publicado na revista Acrópole (216): 470-473, out. 1956, e com algumas alterações na revista Engenharia Municipal (16): 17-20, jan. / fev. / mar. 1960. Curiosamente os desenhos não são exatamente os mesmos da Escola do Jóquei Clube, e tampouco está citado que a análise foi feita para essa escol. A proposta é de um anteprojeto sem um cliente específico, privado ou público, mas no texto está presente a identificação da Comissão de Construções Escolares.

${ }^{28}$ Arquitetura e Engenharia (39): 12, mar. / abr. 1956.

${ }^{29}$ Idem.

${ }^{30}$ Arquitetura e Engenharia (39): 14, mar. / abr. 1956.
} 
No projeto para o grupo escolar do Caxingui, Rocha Leão também se apóia em explicações técnicas que contribuem para definir a arquitetura. Em um texto curto, quase todos os elementos arquitetônicos, a implantação e os volumes do projeto, são explicados como um resultado direto da aplicação de conhecimentos técnicos, apoiados ora em pesquisas científicas de ciências exatas, ora em áreas da psicologia e da pedagogia. A figura 32 é um complemento às explicações do texto.

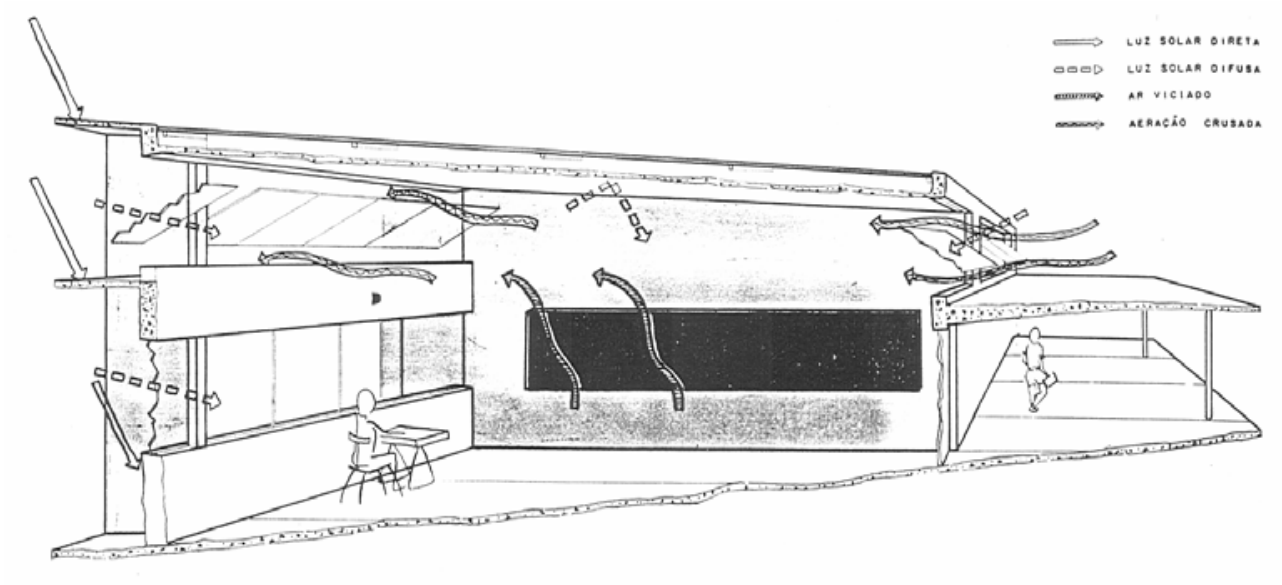

32

Fonte: Acrópole (206): 64, dez. 1955

No texto publicado as referências são bastante claras:

"As crianças são atraídas pelas cores quentes e, segundo estudos dos psicólogos da Universidade Hopkins, com os quais também concordam os psicólogos francezes Sadoum, Coumet e Held, essas cores são ainda estimulantes aos alunos, que é o que se procura atualmente para excitarem a vivacidade de raciocínio e a inteligência, em lugar das côres calmantes usadas antigamente, como por exemplo o verde claro, ainda usado com propriedade nos quartos de hospitais" ${ }^{\prime 1}$.

Também no projeto para o grupo escolar Vila Palmeiras, Rocha Leão explica as questões técnicas ${ }^{32}$ aplicadas para definir o posicionamento da circulação, dos quebra-sóis e o horário de insolação. Nele um só volume concentra todos os ambientes da escola, inclusive o recreio coberto.

As explicações técnicas que alimentam um projeto arquitetônico é prática comum nos projetos da época. A questão é que há uma predominância sobre outros tipos de justificativas

\footnotetext{
31 Acrópole (206): 64, dez. 1955.

${ }^{32}$ Acrópole (194): 77, nov. 1954.
} 
que revelam a origem da arquitetura proposta nas escolas públicas em São Paulo. No exemplo do grupo escolar do Caxingui ${ }^{33}$, não há uma única referência a qualquer tipo de plasticidade abstrata, composição volumétrica ou influência de alguma obra arquitetônica ou obra de arte. Essa atitude não parece ser exclusiva de Rocha Leão, pois em muitos textos foi encontrada a mesma atitude em relação ao projeto. A plasticidade do projeto e a adoção da composição aditiva baseada em grupos funcionais não parecem ter um vínculo direto com as explicações reveladoras de vários dos arquitetos que trabalharam para a $\mathrm{CE}$ e para a Comissão de Construções Escolares.

Um artigo publicado na revista Engenharia Municipal, em 1960, intitulado “A arquitetura também educa", sem autor identificado, (o título contém uma das principais preocupações dos arquitetos que projetaram escolas) revela a maneira de atuar daqueles arquitetos e educadores em geral até aquele momento: "Planejamento Científico: Já passou o tempo em que as escolas eram construídas à exclusiva boa vontade de homens interessados no desenvolvimento de suas comunidades. Hoje, construir uma escola é um trabalho científico, que requer um conhecimento técnico apurado" ${ }^{34}$.

Este é um momento importante na produção de escolas públicas, pois a partir do início da década de 1960, esse discurso cientificista irá progressivamente ceder lugar a uma arquitetura que irá valorizar soluções muito mais universais e generalistas, ainda com uma preocupação pedagógica, porém bastante diferente da que fora feita até aqui.

Nesse artigo de autoria não identificada destaca a preocupação em gerar uma arquitetura que também seja capaz de educar, ou, se explicado de outra maneira, contribuir para a educação dentro da escola. Ao ressaltar que a arquitetura escolar produzida nos Estados Unidos demonstra que é possível responder à pergunta do título positivamente, o autor justifica sua resposta relacionando uma série de diretrizes que, se seguidas, resultariam em um projeto mais adequado à capacidade da arquitetura de influenciar a qualidade da educação nos

\footnotetext{
${ }^{33}$ Cf. Acrópole (206): 62-64, dez. 1955.

${ }^{34}$ Engenharia Municipal (16): 31, jan. / fev. / mar. 1960.
} 
edifícios destinados a uso escolar. Muitas dessas diretrizes, que o texto afirma ser uma conquista das escolas norte-americanas, já estavam sendo aplicadas nas escolas públicas paulistanas. 
4

Novos rumos para a arquitetura escolar 


\subsection{O fim do segundo Convênio Escolar}

Como já foi dito, o município passou a ter uma obrigação constitucional de investir $20 \%{ }^{35}$ de sua renda total no setor de construções escolares. A assinatura dos dois convênios firmados entre Estado e Município em São Paulo foi uma maneira adotada de dividir as responsabilidades sobre a educação. O município construía as edificações e o Estado as mantinha em funcionamento. A duração dos Convênios ocorre entre 1943 e 1954. O segundo Convênio Escolar, que se tornou o mais conhecido em grande parte devido à sua intensa produtividade, teve início em 1948. A obrigatoriedade da prefeitura do município de São Paulo de investir na educação se manteve, gerando a continuidade do setor público responsável pelos projetos, mas agora denominado de Comissão de Construções Escolares. Criou-se, nas publicações especializadas sobre arquitetura, uma relação direta entre a existência do Convênio Escolar e o funcionamento da sua Comissão Executiva. Antes mesmo da data limite, de cunho político, que era o ano de $1954^{36}$, vários dos arquitetos que estavam desde 1949 e 1950 já haviam se retirado da CE. Nesse ano, a Câmara Municipal não ratificou o novo convênio a ser realizado com o Estado ${ }^{37}$.

Foi identificado na pesquisa um dado relevante no processo de construção de escolas: alguns dos projetos realizados durante a vigência do segundo Convênio escolar somente foram realizadas depois de 1954, como o G. E. Vila Vera de Roberto Tibau, cujo projeto está datado de 1952. Isso corrobora a afirmação de Eduardo Corona, que o prazo da execução dos projetos era mais lento do que a realização dos projetos.

Após o término do segundo Convênio Escolar, as atividades se mantiveram através da Comissão de Construções Escolares, incluindo, como se afirmou anteriormente, a execução de projetos feitos anteriormente, com as mesmas instalações e quadros existentes da CE,

\footnotetext{
${ }^{35}$ Engenharia Municipal (11): 7, 1958.

${ }^{36}$ Nesse ano comemoraram-se com fervor os quatrocentos anos de fundação da cidade de São Paulo. Para as festividades foram realizadas inúmeras obras na cidade, incluindo o Parque do Ibirapuera, chamando então de Parque do IV Centenário, e seus principais edifícios.

${ }^{37}$ Cf. JULIÃO (1956), pp. 17-18.
} 
como o atesta a exposição feita no precioso artigo do engenheiro Maury Julião, intitulado “Atividades da Comissão de Construções Escolares", publicado na revista Engenharia Municipal, em 1956, no qual ele enumera as atividades realizadas. Julião foi um dos diretores da Comissão após o término do segundo Convênio, e revela como era dividido o grupo. Havia um setor de Planejamento e outro de Execução, com atribuições distintas. Os projetos ficavam sob responsabilidade do Planejamento. Deve ser ressaltado que a Comissão, assim como a $\mathrm{CE}$, fazia vários outros projetos, como bibliotecas, piscinas públicas, entre outros, além das escolas. A seguir é transcrito um trecho do artigo citado, que contém as principais referências sobre o funcionamento da Comissão:

O Planejamento, além de cuidar da pesquisa de terrenos, em número de trinta e dois no momento, e que no seu total, se destinarão a Grupos Escolares, Ginásios, Parques e Bibliotecas Infantis, prepara oito ante-projetos de construção de novas unidades, sendo de se destacar, dentre eles, o do Colégio Estadual de São Paulo, objeto de convênio especial celebrado recentemente entre o Ministério da educação e Cultura e a Prefeitura Municipal de São Paulo, para a edificação do prédio próprio daquele Educandário.

Prepara ainda o Planejamento sete projetos completos para Colégios, Grupos Escolares, cujos serviços de execução brevemente serão postos em concorrência pública. Dentre estes, merece destaque o do Colégio e Grupo Escolar de São Miguel, o qual, no momento, aguarda apenas alguns detalhes finais de projeto para atingir a fase seguinte, a da concorrência. $\mathrm{O}$ projeto original do Arquiteto Tibau, foi completado em todos os detalhes, sondagens do terreno, cálculo da estrutura de concreto armado, instalações hidráulicas e elétricas, etc.

Ao Planejamento está também encomendado um estudo detalhado da unidade escolar definitiva e que virá substituir as edificações clássicas de concreto e tijolo. Será de execução rápida e de menor custo. Temos grandes esperanças de que através dessa unidade que se planeja, se possa resolver completamente, emprazo curto, o problema da substituição dos galpões por prédios definitivos e com as verbas que se dispõem normalmente para tal fim.

A Execução fiscaliza, atualmente, a construção de trinta e dois prédios. Quinze são Grupos Escolares, oito são Parques e Bibliotecas Infantis, cinco são educandários particulares construídos com auxílio municipal, uma piscina na Mooca, que bem mereceria o nome de balneário, tais as suas dimensões e, finalmente, um Planetário.

Merece ser ressaltado que dos grupos escolares supra citados doze receberam um impulso especial nos últimos dois meses para que fossem os mesmos preparados para entrega em meados de fevereiro, ocasião do reinício das aulas. São eles:

Vila Maria Alta

Vila Ema

Vila Palmeiras

Vila Prudente (Rep. Paraguai)

Jaraguá (Taipas)

Jaçanã (Júlio Pestana)
Vila Zelina Rolim (Guaianazes)

Eng. Goulart

Canindé

Vila Vera (Arthur Saboya)

Dep. Pedro Costa (V. Izolina)

Vila Romana (Thomaz Galhardo) 
A Execução fiscaliza ainda, no momento, a perfuração de sete poços semiartesianos situados em unidades não abastecidas pela rêde de água.

"Além dessas unidades encontram-se para assinatura de contrato, já com concorrências públicas realizadas, prontos portanto para início, dois edifícios para Colégio e seis para Grupos Escolares; há outro em concorrência pública. Há ainda, em preparo, sete outros poços semi-artesianos além daqueles já em perfuração.

Não poderíamos deixar de ressaltar outra atividade da Comissão, embora secundária quanto ao tipo de edificação, mas que propicia solução provisória para o problema da falta de vagas nos Grupos Escolares. Referimo-nos aos galpões de emergência. Eles constituem uma necessidade, por enquanto. A Cidade exige, apenas para atender-se ao crescimento vegetativo da sua população infantil escolar, de muitas dezenas dêles por ano.

Esta outra atividade que se desenvolve durante todo o transcorrer do ano, aguçou-se nestes meses. A Secretaria de Educação do Estado solicitou à Prefeitura a construção de sessenta e três novos galpões para entrega no mês de fevereiro. O pedido originou-se em ofício de 22 de novembro do ano passado. Além destes galpões já havia outros encomendados anteriormente. Estamos em franca atividade de produção de galpões, em série: há hoje setenta e quatro em construção e dez já entregues. Esperamos, no prazo marcado, conclúi-los todos." ${ }^{38}$

\subsection{A situação da rede física escolar mostrada pela pesquisa SAGMACS}

No final de década de 1950, tem início a pesquisa SAGMACS (Sociedade de Análise Gráfica e Mecanográfica Aplicada aos Complexos Sociais), feita sobre a aglomeração paulistana e que teve como coordenador principal o padre Lebret ${ }^{39}$. A SAGMACS era uma empresa de consultoria ${ }^{40}$ e a pesquisa era sobre as condições gerais de vida na aglomeração paulistana. Sobre as questões urbanísticas, foi feita na época uma pesquisa dirigida por Antonio Bezerra Baltar, um engenheiro pernambucano que veio a São Paulo com o objetivo de coordenar esse trabalho. Nesse período, o pesquisador Celso Lamparelli participou com a equipe escolhida para desenvolver os trabalhos na pesquisa SAGMACS, entre 1957 e 1959.

Quando houve a mudança no governo do estado de São Paulo, em 1959, e Carvalho Pinto foi eleito, a equipe coordenadora do novo governo montou uma equipe complexa para fazer o Plano de Ação do governo do Estado, que também abrangia a questão educacional, e de maneira enfática a construção de edifícios escolares no estado. Nesse momento Lamparelli foi convocado para trabalhar com essa equipe no Plano de Ação. E lá ficou responsável, tanto

\footnotetext{
${ }^{38}$ JULIÃO (1956), pp. 17-18.

${ }^{39}$ A pesquisa SAGMACS foi publicada na íntegra, em forma de capítulos dada a extensão de seu texto, nos números 38 a 49 da revista Engenharia Municipal.

${ }^{40}$ Ver Caderno LAP, $n^{\circ} .7$.
} 
por sua experiência anterior, quanto por razões pessoais, segundo ele próprio afirmou, por todo o setor de educação no Plano de Ação do governo de Carvalho Pinto.

O Plano de Ação tinha uma equipe em que estavam Fernando Henrique Cardoso, Delfim Neto, entre outros, e uma equipe executiva, dirigida por Plínio de Arruda Sampaio. Nesse plano, Lamparelli ficou encarregado de coordenar toda a pesquisa e trabalho sobre a parte da educação, tanto da primária como de nível superior. Foram realizadas diversas atividades como: programação e coordenação, realização do controle, distribuição de verba (entre outras atividades que não puderam ser detalhadas), de todo o setor da educação cuja tradição de planejamento era muito baixa.

A crítica feita sobre a política educacional e sua contribuição para a rede física nos anos anteriores a 1959 se baseia principalmente nos dados obtidos com a pesquisa SAGMACS, no depoimento do prof. Celso Lamparelli e de arquitetos que participaram do Convênio como Eduardo Corona e um de seus diretores José Amadei. E mais ainda, como foi reconhecido por vários pesquisadores, que as iniciativas de construção de edifícios escolares, incluindo-se aí o período em que vigorou o segundo Convênio Escolar, não foram suficientes para sanar o déficit das salas de aula que a população em idade escolar da capital necessitava. É fato que até o início da Segunda Guerra Mundial (1939-1945) a quantidade de escolas públicas construídas na cidade de São Paulo, sem considerar a qualidade arquitetônica e técnica dos edifícios, era realmente muito baixa em comparação à necessidade crescente. Porém, mesmo com os Convênios Escolares essa situação continuava sem ser plenamente equacionada. Hoje é possível avaliar que a escolha dos locais onde deveriam ser construídas as escolas feitas pela CE do Convênio Escolar necessariamente não correspondia a algum planejamento feito "a priori", como confirma o depoimento de um dos seus membros mais ativos, o arquiteto Eduardo Corona. Segundo ele, alguns dos terrenos utilizados para construção de escolas eram doações, portanto não eram obtidos segundo um critério de 
localização urbana planejada. E em alguns desses terrenos o projeto das escolas, tal como era feito pela $\mathrm{CE}$, não conseguia ser adaptado a contento.

\subsection{O planejamento escolar}

O levantamento das instalações existentes e da demanda a ser enfrentada é uma necessidade que transparece em cada momento em que surge uma iniciativa pública, estadual ou municipal, de enfrentar o problema da edificação escolar na cidade de São Paulo. No entanto, as dificuldades encontradas para realizar esse tipo de pesquisa eram várias, seja pela extensão da cidade, pela ausência de cadastros públicos confiáveis, ou ainda pela falta de pessoal, material, metodologia ou tecnologia necessária para realizar um censo escolar que permitisse a elaboração de uma pesquisa mais precisa e objetiva. Assim, preparar um planejamento mais adequado à realidade tornava-se uma tarefa de dimensões gigantescas.

Em uma conferência realizada em 1949 e publicada em 1959 (“Os problemas da escola", na revista Engenharia Municipal) o engenheiro José Amadei revela as dificuldades encontradas:

Penetremos agora no setor da edificação propriamente dita.

Se de certo modo pudemos fixar um número para as novas e necessárias edificações para a escola primária, quer para atender os bairros onde ou não existem escolas ou estas são insuficientes, onde localizá-las?

Não encontramos um censo escolar por bairros ou mesmo por subdistritos ou delegacias de ensino, nem conseguimos reunir elementos para conhecer a intensidade do desenvolvimento desses bairros ou sub-distritos.

Recorremos então à única estatística municipal sobre o crescimento da população nos sub-distritos com relação ao recenseamento geral de 1940, não baseada em verificação direta mas em estimativas que, sem dúvida, representam bem aproximadamente a realidade, dado o Departamento que a elaborou.

(...)

E então, como agora, sentimos a falta imensa de uma planta cadastral atualizada.

Os números obtidos evidentemente não são rígidos.

Fixado o ponto de partida, a necessidade mais premente, seguia-se a procura do terreno.

Dimensões, forma, natureza do solo, visinhança prejudicial, facilidades de acesso, afastamento das ruas de tráfego mais intenso, serviços de utilidade pública, situação em relação aos ventos dominantes, panorama, valor comercial, situação em relação às escolas vizinhas, zona que melhor poderá ser influenciada, característica dessa zona etc. 
Evidentemente não tem sido possível obter as melhores condições em cada caso.

Essa pesquisa tem sido para nós difícil e penosa, e só nós e os poucos que nos têm acompanhado a podem julgar, ante o desenvolvimento desordenado dos nossos bairros, arruamentos e loteamentos muitas vezes absurdos, a falta de uma planta atualizada da cidade, e a falta não menor nem menos grave do plano geral de melhoramentos da cidade, de um zoneamento. (AMADEI, 1959, p. 8)

O empenho dos participantes da CE do Convênio Escolar deve ser louvado em face das dificuldades encontradas e dos resultados obtidos, ainda que limitados em relação ao que se propunham resolver.

\subsection{As escolas sem arquitetura e a rede municipal de ensino}

A rede municipal de ensino teve início com os Convênios Escolares, porém a manutenção das edificações e o funcionamento do sistema educacional não ficavam a cargo da Prefeitura, e sim do Estado. Ao contrário do que poderia parecer, tendo a prefeitura à sua disposição um corpo de arquitetos e engenheiros competentes para desenvolver projetos dos mais variados tipos dentre os destinados ao ensino, não foi esse quadro que gerou a rede municipal de ensino. Essa rede surgiu sem arquitetura. Somente mais tarde haveria projetos específicos para o município.

Em 1957 assume a prefeitura o médico Vladimir Toledo Piza, ficando a seu cargo a contratação da pesquisa SAGMACS e do padre Lebret para fazer a pesquisa. Apesar de ficar somente entre oito e nove meses no cargo - essa curta permanência era comum na época - ele também teve que enfrentar o problema da deficiência alarmante de vagas para a escola, fruto do conhecido crescimento vertiginoso da capital paulista, com a imigração, a expansão geográfica e territorial avassaladora, e com uma urbanização intensa e precária. A solução foi determinar que toda normalista formada e competente, isto é, com condição de ensinar a um grupo de crianças, e que conseguisse um lugar para ensinar - qualquer lugar - e que trouxesse uma lista de 40 alunos, seria admitida e paga como professora da incipiente rede municipal de ensino. 
Não havia a necessidade de edificações para essa solução emergencial. Nem de arquitetura. Mas a intensidade do crescimento da cidade levava a soluções inusitadas, como os já citados galpões de madeira, que deveriam ser temporários e alguns acabaram por serem utilizados por algumas décadas. A criação da rede municipal de ensino evidentemente se beneficiou mais tarde da existência de uma Comissão de Construções Escolares que fazia parte da Prefeitura e que não mais dependia de Convênios para funcionar. Os arquitetos que nela trabalhavam tiveram oportunidade de continuar a desenvolver seus projetos, e até mesmo, como em casos que veremos mais adiante, de desenvolver soluções espaciais bastante diferentes das que estavam sendo praticadas até então.

Apesar do surgimento da rede municipal ocorrer em parte devido a uma solução emergencial, surgiram propostas de sistematizar essa rede. O esboço desse sistema, que trataria somente do ensino primário, foi feito pelo engenheiro Rogério Andrade Cezar Filho ${ }^{41}$. No seu projeto há apenas algumas linhas gerais sobre a edificação escolar.

O surgimento da rede municipal também não tem relação direta com o governo federal. Há poucos indícios da presença de decisões relativas à arquitetura que sejam provenientes da esfera de governo federal. Apesar de o Convênio Escolar entre Estado e Município ter se tornado possível em parte devido a uma lei federal, o mesmo não se pode afirmar com relação às diretrizes tomadas em relação ao programa das escolas a serem construídas. No período anterior à $2^{\mathrm{a}} \mathrm{GM}$ a influência é decisiva, pois, como já foi dito, as escolas "platoon" foram um importante referencial adotado no Distrito federal, na época situado no Rio de Janeiro, e essa referência alcança o estado de São Paulo. Durante a existência do Convênio Escolar, ao que se pôde averiguar, há alguns poucos indícios da presença da esfera federal na arquitetura dessas escolas. Uma informação digna de nota transparece em uma das várias publicações que contêm o Colégio estadual da Penha, projeto de Eduardo Corona, na revista Habitat, na qual há a indicação de que o projeto foi feito

\footnotetext{
${ }^{41}$ Engenharia Municipal (11): 7-11, 1958
} 
“obedecendo completamente o programa do Ministério da Educação para escolas dessa natureza" ${ }^{42}$. Essa referência aparece também na revista AD - Arquitetura e Decoração ${ }^{43}$. Esse projeto têm sido um dos mais publicados, dentre os que foram feitos pela CE do Convênio Escolar. É fato que "a Constituinte de 1934 delegou à União a responsabilidade de um Plano Nacional de Educação" (OLIVEIRA 1991 p. 311), porém são pouquíssimos os indícios dessa influência na arquitetura e na organização programática das escolas. Ao contrário parece haver uma certa autonomia nos projetos de escola nessa época na cidade de São Paulo.

\subsection{O início da pesquisa SAGMACS e a rede escolar}

A coordenação do setor educacional do Plano de Ação elaborado em 1959 insistia na realização de uma pesquisa que fizesse um levantamento preciso da situação da educação tal qual se encontrava na época, em face da quase total ausência de dados confiáveis. Para isso Celso Lamparelli entrou em contato com Carlos Pasquale, na época secretário da Educação do município de São Paulo. As diferenças existentes nas relações internas entre os funcionários de diversas instâncias dentro do governo estadual geraram a necessidade de convencer todos os participantes de que essa etapa era necessária. Em especial no que se referia à rede escolar, pois o Plano tinha um setor de investimentos. Os participantes do Plano, em especial aqueles que já tinham atuado dentro da pesquisa SAGMACS, já tinham uma noção da dificuldade em que se encontrava a rede escolar, especialmente na capital. Os dois anos que se passaram da realização da pesquisa SAGMACS não foram de forma alguma suficientes para melhorar a situação.

A pesquisa SAGMACS avaliou o nível de atendimento da educação, das condições dos prédios, entre outros dados, e a partir daí verificou-se a precariedade das condições em que se encontrava a rede escolar. A coordenação do setor educacional do Plano de Ação, já sabendo da condição precária anterior, deparou-se também com um outro problema, que era a

\footnotetext{
${ }^{42}$ Revista Habitat (13): 19-21, dez. 1953.

${ }^{43} \mathrm{AD}$ - Arquitetura e Decoração (3): dez. / jan. 1954.
} 
baixa qualidade das informações disponíveis sobre a rede escolar. No seu texto final revela que a pesquisa "não permitiu uma avaliação precisa das necessidades", mas que "o problema de falta de vagas, sobretudo nas áreas periféricas" 44 era algo concreto. A meta do Plano de Ação era construir, em quatro anos, uma quantidade substancial de escolas e salas de aula de ensino médio e primário.

\subsection{A leitura de projetos de outros países}

Enquanto o Estado introduzia modificações profundas na forma de construir e gerenciar a rede física de ensino e a própria educação, o sistema municipal de ensino -que já se tornara há alguns anos parte integrante do corpo da Prefeitura - continuava suas atividades. Mas assim como o Estado procurava atualizar sua maneira de atuar frente à questão da educação, incluindo o edifício escolar, o sistema municipal que tratava do assunto também, através da iniciativa dos profissionais que atuavam dentro da Comissão de Construções Escolares.

Nas instalações da Comissão de Construções Escolares, e que eram as mesmas que haviam sido utilizadas pela CE do segundo Convênio Escolar, havia uma rica biblioteca alimentada constantemente com publicações nacionais e estrangeiras. Segundo depoimento de Aluísio Rocha Leão, os arquitetos e demais profissionais podiam manter-se atualizados com o desenvolvimento da arquitetura em outros países e em outros projetos realizados no Brasil. Isso posto, poder-se-ia supor que a influência dos trabalhos de Richard Neutra, ou mesmo de Josep Lluis Sert, tivessem alcançado as atividades da Comissão em São Paulo. Se isso de fato ocorreu - e há até mesmo soluções em comum entre os projetos desses arquitetos e as escolas analisadas neste trabalho - não é algo que permita caracterizar de maneira definitiva essa leitura como uma mera cópia de projetos ou como importação de soluções. Tudo indica que houve sim, a absorção das principais características da arquitetura moderna e de suas

\footnotetext{
${ }^{44}$ Engenharia Municipal (48): 29, set. / out. 1970.
} 
propostas universais. A aplicação dessas fórmulas e conceitos que tanto têm sido objeto de estudo de inúmeros trabalhos sobre arquitetura, passou por um processo de adaptação. Essa adequação não elimina a presença, como foi dito, de soluções em comum, entre os projetos feitos em outros países e os que foram feitos em São Paulo..

No caso das obras de Richard Neutra, é possível verificar que há algumas soluções que ocorrem com alguma freqüência nas escolas analisadas aqui. A "independência de uma ordem fixa de assentos nas salas de aula", a "luz vinda de cima" substituindo "a janela" e "cada sala de aula com a possibilidade de expansão das atividades de ensino para o ar livre" ${ }^{45}$. Essas propostas fizeram parte do Manufactured Ring Plan School, desenvolvido em 1923. Esse projeto não foi realizado, porém serviu de referência a inúmeras escolas desenhadas por Neutra nas décadas posteriores nos Estados Unidos.
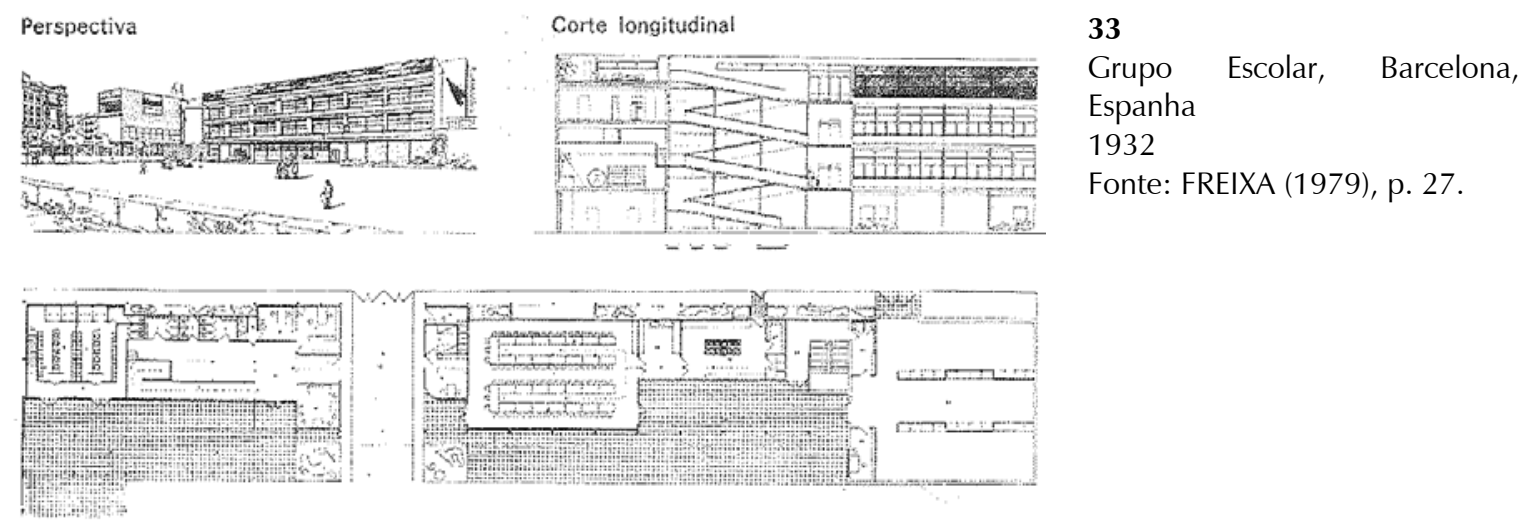

Planta

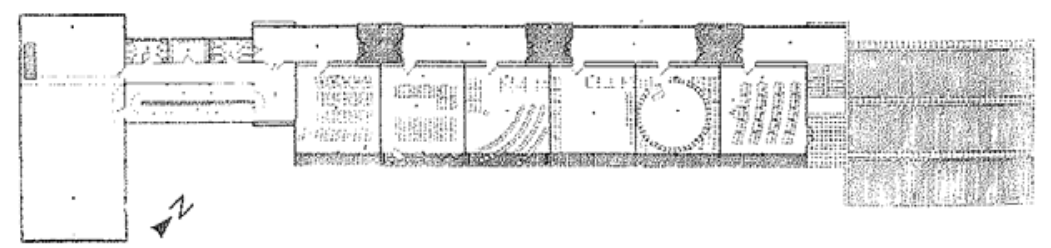

Alguns anos mais tarde, Josep Lluis Sert realiza, em equipe, projetos de escolas que também procuravam seguir novas doutrinas e novas formas de conceber espaços adequados à nova educação. Nesses projetos se encontram soluções que estavam se disseminando por vários países (figuras 33 e 34), como as salas de aula que abrem para pátios ao ar livre, o uso

\footnotetext{
${ }^{45}$ Cf. KULTERMANN (1957), p. 45 e 47.
} 
de plantas lineares, com salas dispostas ao longo de corredores extensos, a ventilação cruzada e a proposta de agregar outros usos ao edifício escolar (piscinas, quadras esportivas, atelier) ${ }^{46}$. Os projetos feitos em conjunto com pedagogos revelam também uma prática que se estenderia por todo o século XX: as escolas são projetadas para se adequarem a novas propostas de ensino.
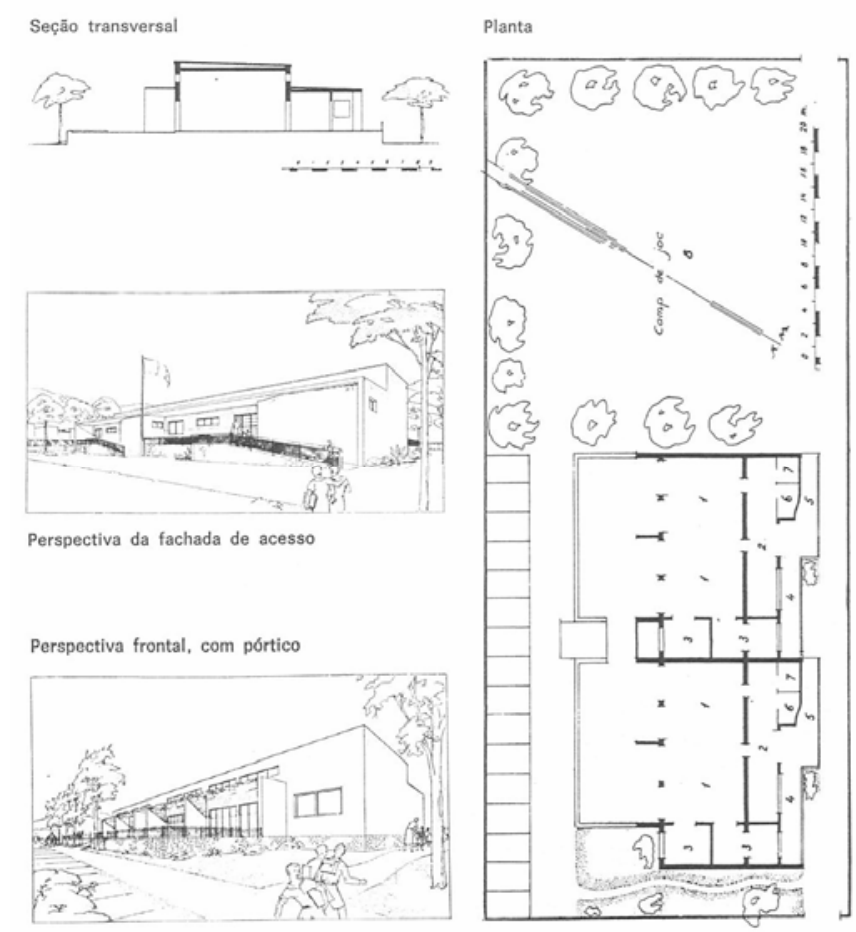

34

Escola Elementar rural em Palausolitar, Barcelona, Espanha

1932

Fonte: FREIXA (1979), p. 26.

Pode-se ir além e reconhecer alguma similaridade entre um projeto de Roberto Tibau, que se destaca entre as arquiteturas que compõem o repertório da maioria das escolas públicas em São Paulo, e um projeto de Richard Neutra (figuras 35 e 36).

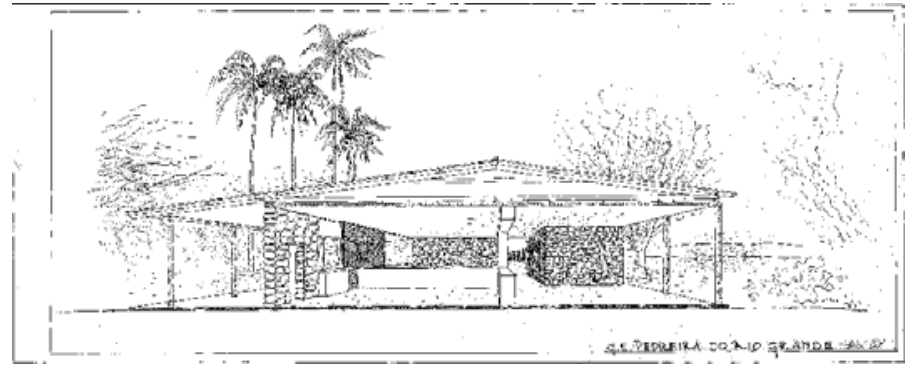

35

G. E. Pedreira do Rio Grande (G. E. 69)

Autor: Roberto Tibau

Fonte: Arquivo EDIF-PMSP

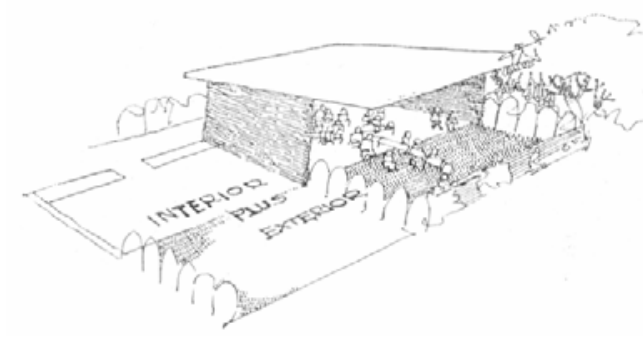

36

Escola rural (proposta) Richard Neutra Fonte: NEUTRA, 1948.

\footnotetext{
${ }^{46}$ Cf. FREIXA (1979), p. 26 e 27.
} 


\subsection{Os galpões de madeira}

A urgência da construção de escolas para atender a demanda e a diferença entre a capacidade de projetar e construir grupos escolares foi durante anos uma das principais preocupações dos arquitetos e engenheiros ligados a esse tipo de construção. Entre outras soluções, foi aplicado o projeto de galpões de madeira, que deveriam ser construções temporárias para sanar a falta de vagas crescente, até que edifícios "permanentes" fossem construídos.

Até o final do século XX ainda se encontravam alguns desses galpões funcionando como escolas na capital paulista.

A tabela 4 contém as escolas de madeira construídas até 1955. Ela revela que alguns desses projetos foram feitos ainda durante a vigência do segundo Convênio Escolar, que se encerrou em 1954.

Tabela 4 - Listagem dos galpões de madeira construídos até 1955

\begin{tabular}{|c|c|c|c|}
\hline Nome da escola & Número de salas & Nome da escola & Número de salas \\
\hline 1. Jardim Brasil & 2 & 39. Vila Guilherme & $1 \frac{1 / 2}{2}$ \\
\hline 2. Vila Sabrina & 2 & 40. Parque Shiba & $2 \frac{1}{2}$ \\
\hline 3. Chora Menino & 2 & 41. Penha & 2 \\
\hline 4. Imirim & 2 & 42. Jardim Tremembé & 2 \\
\hline 5. Vila Isolina II & $1 \frac{1}{2}$ & 43. Arthur Alvim & 1 \\
\hline 6. Jardim Maristela & 4 & 44. Canindé & $4 \frac{1}{2}$ \\
\hline 7. Vila Indiana & 2 & 45. Jaçanã & 2 \\
\hline 8. Vila Pazzini & 2 & 46. Alto de Vila Maria & 4 \\
\hline 9. Escola Nazareth & 2 & 47. Vila Matilde & $2 \frac{1}{2}$ \\
\hline 10. Vila Carioca & $2 \frac{1}{2}$ & 48. Santo Amaro & 4 \\
\hline 11. Bairro Campo Grande & 2 & 49. Vila Salete & 4 \\
\hline 12. Vila Bertioga & $11 / 2$ & 50. Vila Munhoz & $1 \frac{1 / 2}{2}$ \\
\hline 13. Jardim Mendonça & 2 & 51. Vila Izabel & 2 \\
\hline 14. Praça das Rosas & 2 & 52. Jardim Três Marias & 2 \\
\hline 15. Jardim Thialia & 2 & 53. Vila Progresso & 1 \\
\hline 16. Parque São Lucas & $1 \frac{1 / 2}{2}$ & 54. Vila Sapopemba & 2 \\
\hline 17. Vila Esperança & $1 \frac{1 / 2}{2}$ & 55. Vila Carioca & $2 \frac{1}{2}$ \\
\hline 18. Vila Gomes Cardim & 2 & 56. Vila Babilônia & 1 \\
\hline 19. Morro Continental & 2 & 57. Vila Beatriz & 2 \\
\hline 20. Vila Josefina & 2 & 58. Mooca & 2 \\
\hline 21. Vila Carolina & 2 & 59. Vila Pompéia & 4 \\
\hline 22. Km. de Osasco & 2 & 60. Vila Osasco & 3 \\
\hline 23. Vila Santo Antônio & 2 & 61. Jardim Jussara & 1 \\
\hline 24. Freguesia do Ó & 2 & 62. Vila Califórnia & 4 \\
\hline 25. Jardim Piratininga & 4 & 63. Vila Seabra & 1 \\
\hline 26. Caragoatá & 1 & 64. Vila Guarani & $31 / 2$ \\
\hline 27. Vila Sabará & $2 \frac{1}{2}$ & 65. Vila Simões Cerca & 2 \\
\hline
\end{tabular}




\begin{tabular}{ll|ll}
\hline 28. Santo Amaro & 4 & 66. Chácara das Flores & 2 \\
\hline 29. Vila Friburgo & 2 & 67 . Capela do Socorro & 1 \\
\hline 30. Vila Clementino & 2 & 68 . Cangaíba & 4 \\
\hline 31. Xangrilá & 1 & & \\
\hline 32. Jabaquara & 2 & & \\
\hline 33. Jardim Botucatu & $31 / 2$ & \\
\hline 34. Tuparoquera & 1 & \\
\hline 35. Vila Constância & $21 / 2$ & \\
\hline 36. Cidade Mãe do Céu & 2 & \\
\hline 37. Vila Sabrina & 2 & \\
\hline 38. Vila Munhoz & $21 / 2$ & \\
\hline
\end{tabular}

Fonte: Engenharia Municipal (13): 7-8, abr. / mai. / jun. 1959.

Até o ano da publicação da tabela 4, foi construído um total de 68 galpões de madeira. A finalidade era a mesma, porém a construção obedecia a critérios diferentes de aplicação. Alguns galpões eram construídos junto a escolas existentes, para aumentar o número de salas de aula. Outros eram construídos isoladamente, como grupos escolares, com cozinha própria inclusive. Não foi possível confirmar na pesquisa qual projeto correspondia aos galpões de madeira.

\subsection{As escolas da Comissão de Construções Escolares}

Dentre os projetos realizados após o término do segundo Convênio Escolar está uma das maiores edificações destinadas ao ensino primário e ginasial da cidade. O Colégio Estadual de São Paulo foi um dos maiores projetos da Comissão de Construções Escolares, merecendo espaço em vários periódicos ${ }^{47}$, e louvado como uma das principais obras da Comissão. Esse colégio também era denominado de Colégio Cidade de São Paulo ${ }^{48}$. Estranhamente, seu projeto ficou sob a responsabilidade de dois jovens arquitetos - Rubens César Madureira Cardieri e Rubens Freitas Azevedo - que se formaram na Faculdade de Arquitetura da Universidade Mackenzie, e não de arquitetos mais experientes. O projeto consiste em duas escolas em um só conjunto (figura 37), incluindo um ginásio esportivo coberto (figura 38).

\footnotetext{
${ }^{47}$ Entre outras publicações: Arquitetura e Decoração (26): dez. 1957 e Engenharia Municipal (13): 31-34, abr. / mai. / jun. 1959, como o nome de Colégio Cidade de São Paulo.

${ }^{48}$ Engenharia Municipal (13): 2, abr. / mai. / jun. 1959
} 
Em artigo publicado na revista Habitat ${ }^{49}$, ao contrário de outros textos sobre escolas públicas em que há somente uma descrição de usos e de aspectos construtivos do projeto, o texto revela claramente a construção do ideário moderno nos projetos realizados desde o início do segundo Convênio Escolar até aquele momento. As premissas são as seguintes: a ausência de ornamentos, o uso de formas arquitetônicas adequadas a um projeto "voltado para o fato social que representa", a continuidade de uma orientação conferida pelo arquiteto Hélio Duarte e o uso de uma "discreta ordenação de linhas simples e harmoniosas". Essas quatro observações são um resumo do ideário da arquitetura moderna que percorreu a descrição da grande maioria das escolas públicas construídas entre 1936 e 1962.

Com exceção da referência sobre a influência de Hélio Duarte, as outras observações podem ser facilmente encontradas em outros textos de revistas para descrever as qualidades de projetos de escolas. Essas observações se estendem desde a década de 1930 até o início da década de 1960. Há um momento que o texto revela o que une as observações citadas anteriormente. O artigo afirma que "a bela organização de espaço está dentro dos princípios da lógica interna num inteligente e flexível relacionamento de suas partes" $"$. A "lógica" que o artigo cita é a lógica da era da máquina e da ciência. A seqüência de salas de aula ao longo do corredor é, de fato, a moderna linha de produção - neste caso de cidadãos - perfeitamente organizada com o objetivo de colher as crianças e, ao final do processo, tê-las "formado" plenamente. Essa lógica se traduz também na composição aditiva dos volumes da edificação, e era exaltada pela capacidade de demonstrar externamente o sistema de ensino em série.

Essa leitura deste projeto pode ser estendida para a maioria das edificações produzidas tanto pela $\mathrm{CE}$ quanto pela Comissão de Construções Escolares, tendo em vista a organização de caráter industrial que os edifícios continham. Essa não é a única explicação para as soluções formais adotadas naquelas escolas. Porém, a proximidade da arquitetura dessas

\footnotetext{
${ }^{49}$ Habitat (37): 66-70, dez. 1956.

${ }^{50}$ Habitat (37): 68, dez. 1956.
} 
escolas com certa lógica industrial é um dos principais componentes da época em que foram feitas.

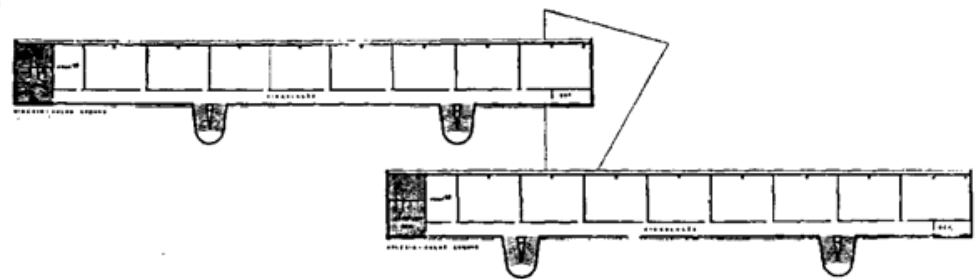

Plonta des pavimentoì nuperiores

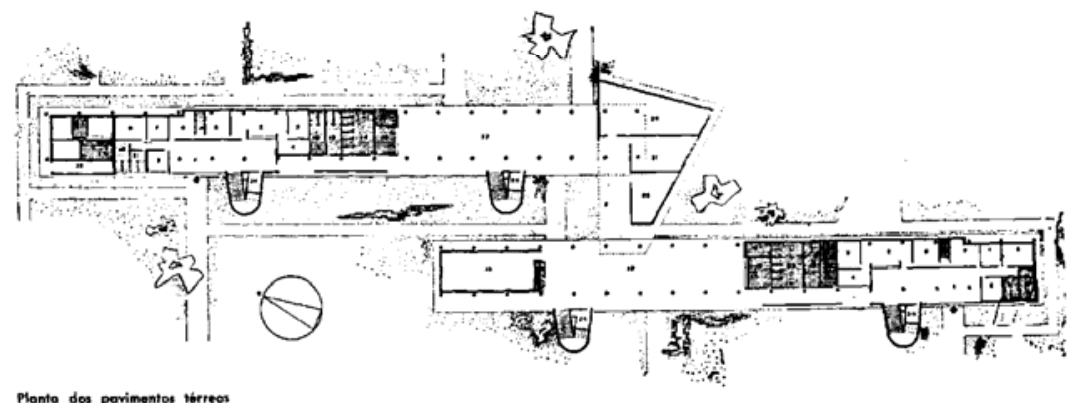

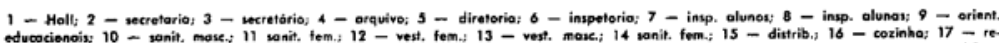

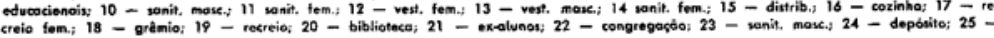

Colégio estadual São Paulo, também denominado Colégio Cidade de São Paulo. Plantas do térreo e do pavimento superior dos dois blocos de ensino (ginásio e primário).

Fonte: Acrópole (247): 249, maio 1959.

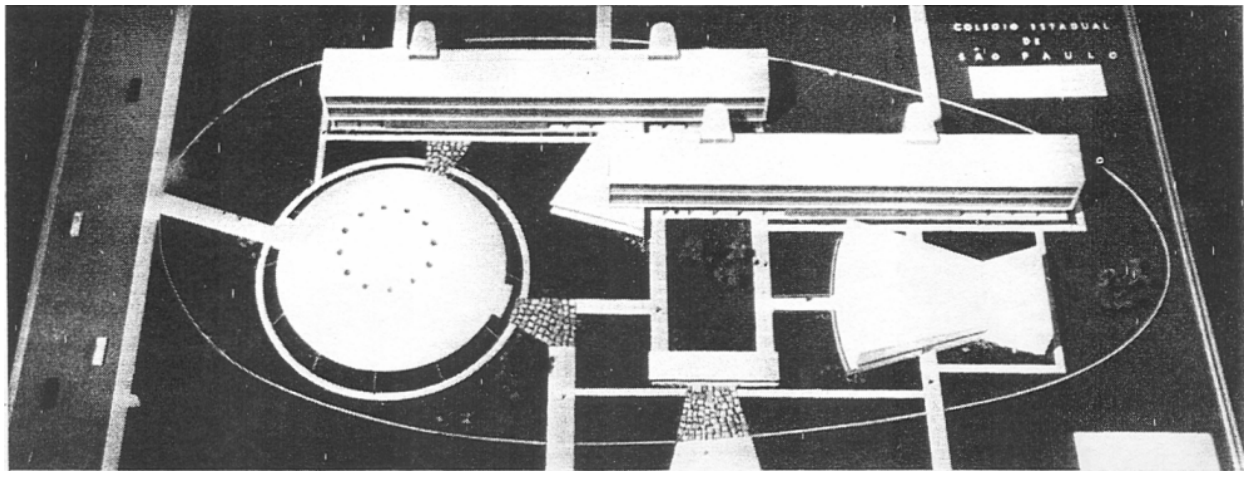

38

Colégio estadual São Paulo, também denominado Colégio Cidade de São Paulo.

Foto da maquete.

Fonte: Acrópole (247): 251, maio 1959.

No projeto do Instituto Municipal de Crianças Surdas - autoria de Aluísio Rocha Leão e Roberto Tibau - na Aclimação, os arquitetos reafirmam a forte presença da ciência na arquitetura no artigo publicado na revista Acrópole ${ }^{51}$. Esse projeto é considerado pelo próprio Rocha Leão como um dos mais importantes de sua carreira, durante a época que atuou como

\footnotetext{
${ }^{51}$ Acrópole (272): 276, julho 1961.
} 
arquiteto, antes de se dedicar às artes plásticas, principalmente a pintura. Assim como os demais projetos da Comissão de Construções Escolares os volumes usados na composição aditiva são principalmente lineares e estreitos, ainda que a arquitetura que foi proposta contenha um caminho diferente que seria desenvolvido mais adiante. Essa prática em grande parte era justificada pela necessidade de insolação das salas de aula. Porém neste projeto os autores revelam uma outra justificativa, vinculada à idéia de higiene e salubridade, e que não é nova: a renovação do ar dos ambientes internos. Nesse caso a renovação, segundo seus autores, ocorreria 9 vezes por hora ${ }^{52}$.

No projeto do Grupo Escolar de Vila Ema, da autoria de Paulo J. R. Rosa é certamente um dos que fogem à regra dos volumes lineares, com salas de aula de um lado somente do corredor de acesso $^{53}$. Neste peculiar projeto, cuja solução arquitetônica parece ter sido imposta pelas "exíguas dimensões do terreno", há salas de aula de ambos os lados do corredor central. A edificação permanece horizontal como as demais, e a insolação bilateral e ventilação cruzada - ou bilateral como às vezes se costumava denominar - ocorre através de um "shed", que parece satisfazer muito bem os critérios adotados para qualificar um projeto de escola.

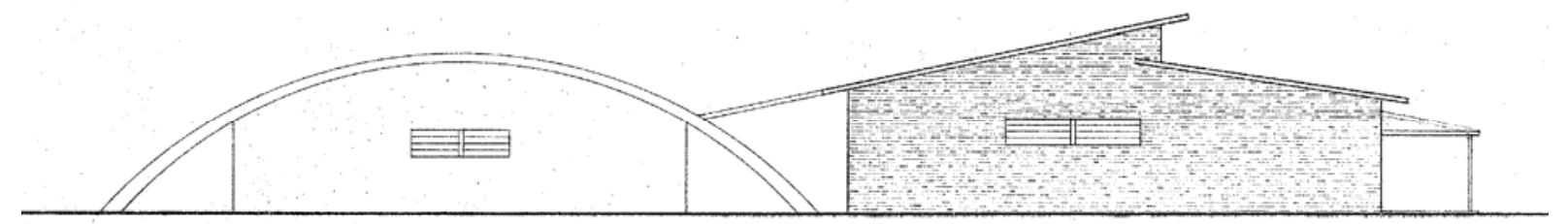

FACHADA LESTE

39

Pode-se ver na elevação a solução de iluminação e ventilação zenital usada no projeto.

Fonte: Arquivo EDIF - PMSP

\footnotetext{
${ }^{52}$ Engenharia Municipal (22): 24, jul. / ago. / set. 1961.

${ }^{53}$ Habitat (26): 41, jan. 1956.
} 


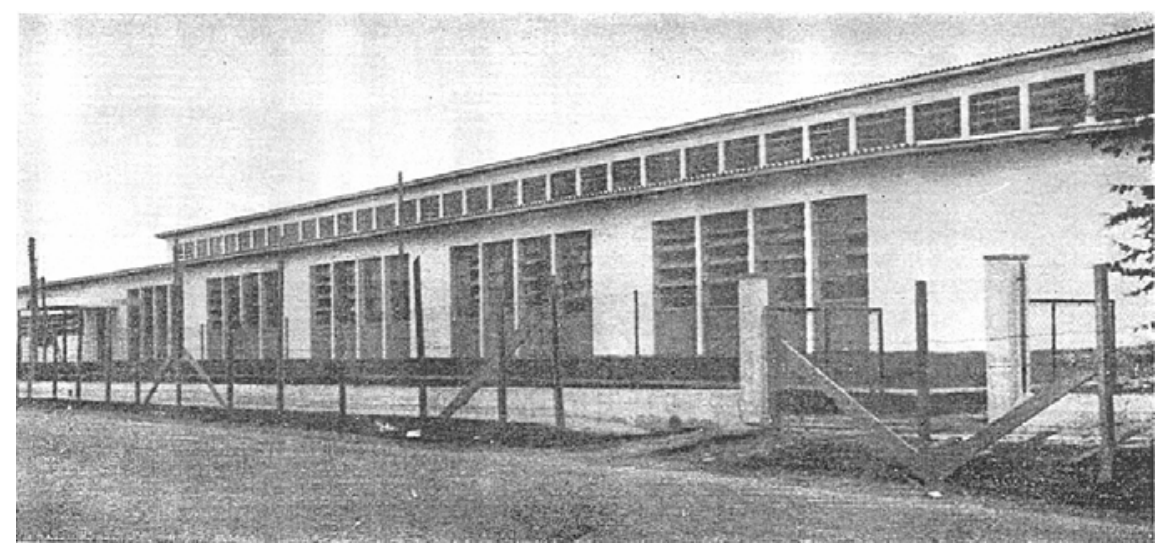

40

G. E. Vila Ema

Fonte: Habitat (26): 40, jan. 1956

O "shed" utilizado no projeto (figura 39 e 40) também permitia a iluminação do seu interior. Estranhamente essa solução não foi utilizada nos outros projetos feitos na CE e na Comissão de Construções Escolares identificados nesta pesquisa.

Esse projeto é um dos que foi realizado na classificação de Grupo Escolar Econômico. Outros grupos idênticos foram construídos de acordo com o mesmo projeto, desde $1956^{54}$, nas seguintes localidades: Jardim Japão, Jardim São Paulo, Saúde, Vila Jaguará, Capela do Socorro, Vila Curuçá, Canindé, Vila Maria, Vila Diva, Vila Formosa, Vila Luzitana, Jardim Penha, Cidade Dutra, Pirituba e Cidade Dutra. Essa lista consta de um artigo que parece ter sido escrito pelo arquiteto Paulo J. R. Rosa, porém pelo menos em três dos projetos indicados a escola que foi construída é completamente diferente do Grupo Escolar Econômico. São elas: Jardim Penha, Jardim São Paulo e Canindé. Excluindo-se o projeto do G. E. de Vila Vera, não foram localizados nos arquivos da EDIF e em outras fontes os projetos das demais localidades indicadas no artigo e nas quais teria sido construído o edifício designado Grupo Escolar econômico. A justificativa indicada para a criação de um edifício padrão era a necessidade de realizar uma construção em larga escala e com execução rápida e econômica, para atender “a crescente necessidade de escolas", razões que têm sido recorrentes desde a década de 1930.

\footnotetext{
${ }^{54}$ Engenharia Municipal (13): 35, abr. / mai. / jun. 1959.
} 
Ele seria construído em terrenos resultantes de arruamentos realizados na capital, com autorização da Câmara Municipal, a partir de $1955^{55}$.

Em outro raro projeto de grupo escolar que adotou salas de aula de ambos os lados do corredor de acesso, o arquiteto Rubens Cardieri explica, em um artigo sobre o projeto, que a adoção de um bloco único para agrupar todos os ambientes da escola foi devido às condições topográficas acentuadas do terreno. No G. E. Cangaíba há um único bloco linear, com dois pavimentos.

Os projetos acima analisados ainda soam como exceções em um momento em que predomina largamente o uso de volumes estreitos e lineares, com uma composição aditiva de zoneamento funcional. Nos artigos que descrevem esses projetos são enunciadas todas as explicações necessárias para justificar porque não foi utilizada a solução "tradicional". O curioso é notar por que essas soluções não foram também adotadas como padrões a serem seguidos.

Em um projeto de 1955, o grupo escolar de Vila Matilde (figura 41), o arquiteto Roberto Tibau utiliza um caminho que será desenvolvido mais tarde, que é o uso de uma planta na qual os volumes não mais se desenvolvem independentemente e depois são agrupados em torno das áreas de circulação. Nesse projeto os ambientes ainda agrupados por finalidades específicas são acoplados, para gerar outros ambientes necessários ao grupo escolar, como o pátio de recreio. Nessa solução, ainda que as coberturas utilizadas procurem destacar uma separação entre volumes, não ocorre de forma tão nítida quanto a composição aditiva de volumes lineares amplamente utilizada em projetos como esse. A horizontalidade do projeto (possui apenas um pavimento) contribui para esse resultado plástico, mas ainda não é possível afirmar que há um vínculo direto com as inovações introduzidas no final da década de 1950 e início de 1960. Nesse projeto também foi utilizada uma solução que se tornaria padrão em muitos outros projetos, que é a possibilidade de isolar o pátio de recreio, mantendo

\footnotetext{
${ }^{55}$ Idem.
} 
nele o acesso a banheiros e cozinha, e entrada principal da escola, para assim poder ser utilizado de forma segura pela comunidade que utiliza a escola, para realizar "festas, reuniões, palestras, representações teatrais para a comunidade" ${ }^{, 56}$.
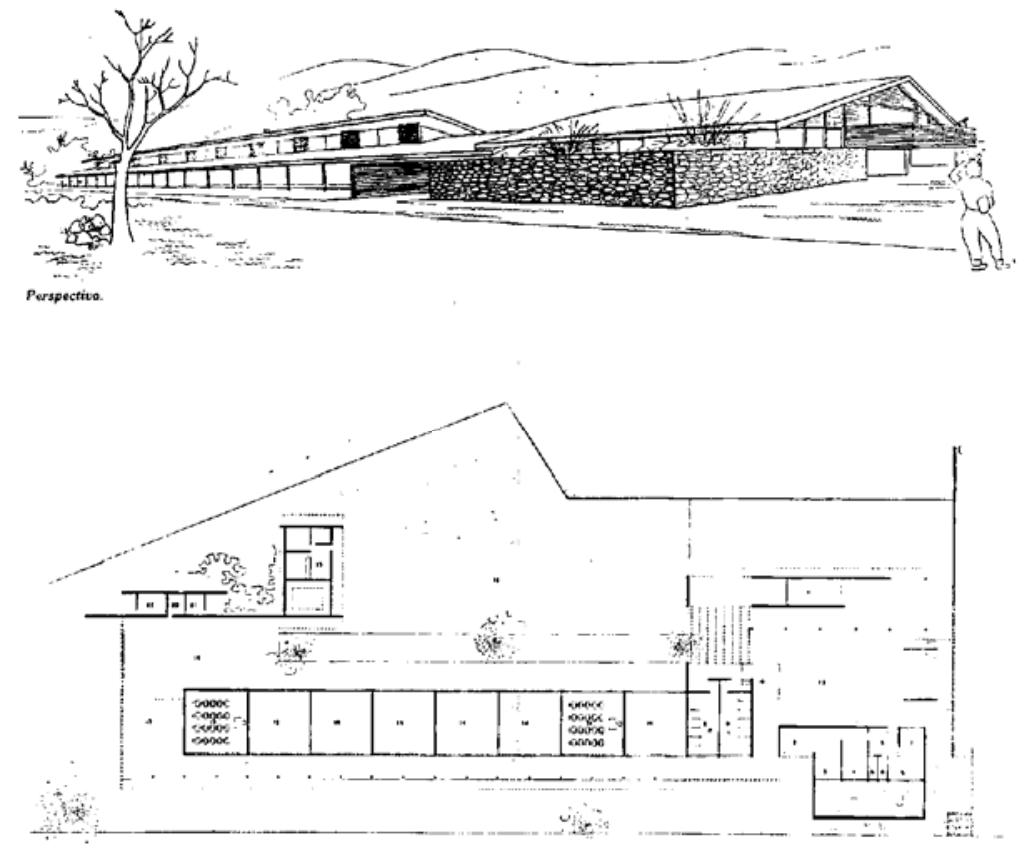

41

G. E. Vila Matilde

Autor: Roberto Tibau

Fonte: Engenharia Municipal (13): 26, abr. / mai. / jun. 1955.

Os arquitetos participantes da CE e da Comissão de Construções Escolares também atuavam, em paralelo, fora do âmbito municipal, prestando serviços para outros clientes.

\subsection{A separação entre Prefeitura e Estado: a iniciativa municipal}

Após o ano de 1954, data limite para que a Comissão Executiva do Convênio Escolar alcançasse as irrealizáveis metas propostas de construção de salas de aula no município, os projetos continuaram a ser feitos. Alguns dos primeiros arquitetos que ali entraram, muito ainda no início de carreira, mesmo antes daquele ano já haviam se retirado da Comissão Executiva do Convênio Escolar. Porém as instalações e a organização da CE, que eram municipais, pois cabia ao governo do Estado manter as escolas após sua construção, foram mantidas, e existem até hoje. Nesse momento posterior ao do Convênio Escolar, as atividades

\footnotetext{
${ }^{56}$ Engenharia Municipal (13): 26, abr. / mai. / jun. 1955.
} 
não parecem ter parado, apenas perderam o vigor inicial imposto pelo curto prazo político. Da mesma maneira as referências arquitetônicas estabelecidas inicialmente se mantiveram, mas alguns acréscimos e mudanças de alguns elementos arquitetônicos foram feitos durante os anos que se seguiram, ainda que sem modificar profundamente a arquitetura inicialmente proposta. Vários arquitetos tiveram atuação importante na segunda metade da década de 1950, dentro do que passaria a se chamar Comissão de Construções Escolares.

No projeto de um ginásio para Osasco (na época a cidade de Osasco era ainda um bairro de São Paulo), Paulo Rosa acrescenta alguns elementos típicos da arquitetura da década de 1950, que são as abóbadas sucessivas, com colunas inclinadas nas abóbadas das extremidades, mas que ainda não haviam sido utilizadas em projetos da $\mathrm{CE}$ até então ${ }^{57}$. Outra solução adotada que, como já foi dito anteriormente, também não era comum são as salas de aula com dimensões e outros elementos construtivos feitos especificamente para um fim, como é o caso da sala de desenho. Ainda assim trata-se de exceções, que na verdade só confirmam a convergência de soluções adotadas na época.

Em um dos projetos feitos na época, Paulo Rosa também se utiliza de uma solução de edifício que se repete, não com o mesmo projeto, em termos dimensionais, mas com uma organização espacial e volumétrica extremamente semelhante, o que parece ser uma atitude que já não mais depende da pressão do tempo mas sim de um recurso que permite explorar uma mesma solução já previamente conhecida e que atende às expectativas de quem irá executar a obra e usar a escola. É o caso dos Grupos Escolares Jardim Ademar $^{58}$ e Raul Fonseca. As dimensões e os ambientes não são idênticos, porém os volumes, a disposição entre eles, a circulação e a organização interna são muito semelhantes.

Apesar de em 1959 ter surgido o Plano de Ação, que era estadual, A comissão de Construções Escolares ainda parece estar atuando como se fosse um Convênio entre esferas

\footnotetext{
57 Acrópole (193): 10-13, out. 1954.

${ }^{58}$ Acrópole (200): 362-363, jun. 1955.
} 
públicas distintas. Um exemplo é o Colégio Estadual de São Paulo ${ }^{59}$, um conjunto de edificações de grande porte. A arquitetura do colégio é bastante semelhante ao que estava sendo feito anteriormente, mas aqui também começam a surgir algumas situações que são novas, como o uso de dois edifícios de níveis de ensino independentes reunidos em uma só escola e o projeto anexo de um ginásio grande o suficiente para receber não só jogos e atividades da própria escola.

\subsection{O Plano de Ação do Governo do Estado e os escritórios de arquitetura}

No Plano de Ação do governo estadual de Carvalho Pinto havia a previsão de construção de cerca de 7000 salas de aula do ensino que na época se chamava primário, com capacidade para 560.000 novos alunos e mais 1.100 salas de aula para o então chamado ensino secundário e normal ${ }^{60}$. É importante notar, que ao contrário do que ocorrera anteriormente, o estado pretendia desenvolver uma ação de grande porte, mas na capital paulista não havia sinais de que haveria alguma cooperação com o poder municipal. Muito pelo contrário, a prefeitura manteve seus quadros de arquitetos trabalhando dentro do órgão que antes era a Comissão Executiva do Convênio Escolar e que mais tarde daria origem à EDIF, responsável pela manutenção e projetos de todos os edifícios da rede pública municipal.

A partir de 1959, o governo de Carvalho Pinto modifica sensivelmente a forma pela qual o Estado intervinha no problema da construção de edifícios escolares. Naquela época, o IPESP, Instituto de Previdência do estado de São Paulo, contrata escritórios de arquitetura estabelecidos para realizarem os projetos. Pela primeira vez, desde a atuação do arquiteto Ramos de Azevedo, os projetos não são mais feitos por funcionários públicos, mas sim por profissionais contratados especificamente para esse fim. Essa iniciativa fazia parte do Plano de Ação instituído naquele governo, e que consistia em um conjunto de metas a serem

\footnotetext{
${ }^{59}$ Acrópole (247): 248-251, maio 1959.

${ }^{60}$ Acrópole (249): 1, jul. 1959.
} 
alcançadas em diversos âmbitos, não se atendo apenas ao plano educacional. Nesse momento é inaugurada uma outra forma do Estado realizar projetos para construções escolares públicas, e que se mantém até hoje, a de utilizar os quadros profissionais que atuam na área privada, contratando-os para realizar os projetos.

\subsection{O Fundo Estadual de Construções Escolares e o Instituto de Previdência}

\section{do Estado de São Paulo}

O crescimento demográfico da cidade de São Paulo é enorme no final da década de 1950. Em 1920 a população da capital é de 579.033 habitantes, em 1940 chega a 1.378 .669 e em 1950 alcança 2.198 .096 pessoas. No ano de 1957 chega a espantosos 3.149.504 habitantes $^{61}$. Para enfrentar o problema do contínuo déficit de vagas escolares fez-se necessária uma organização mais eficiente e capaz de atender a uma demanda gigantesca e que afetava não só a cidade de São Paulo, como o estado também ${ }^{62}$.

Então, no Plano de Ação se estabeleceu que nos três anos e meio do governo, que faltavam dos quatro anos do Carvalho Pinto, seriam construídas seis mil salas de aula no estado. Para fazer isso, era preciso agilidade, padronização, equipe autônoma, recursos próprios e independência total da morosidade do aparato estatal. Então o FECE, Fundo Estadual de Construções Escolares inicia o seu trabalho na década de 60, e montam-se planos anuais de construção em grande escala, com arquitetos contratados fora do setor público.

O FECE, que foi instalado em 1959, começa a atuar em 1960 até 1962. Criado inicialmente por Celso Lamparelli e por outros profissionais como Flávio Villaça, Clementina de Ambrósio e Mayumi Souza Lima, teve como diretor executivo Carlos Pasquale, no momento em que no Estado se introduzia uma série de conceitos novos sobre sistema educacional. Tem início uma maneira de atuar na construção da rede física da educação de

\footnotetext{
${ }^{61}$ Engenharia Municipal (41): 50, jul. / ago. 1969

${ }^{62}$ A demanda de vagas no ensino público também era um problema no Rio de Janeiro. As duas principais cidades do país sofriam de problemas semelhantes na mesma época, mas ao que parece as soluções adotadas foram bastante diversas, pois as dificuldades a serem enfrentados também não eram exatamente as mesmas. Cf. CAVALCANTI (2001).
} 
ensino primário e do ensino médio que persiste ainda hoje, indo desde a escolha do terreno, definição do programa, contratação de profissionais fora do setor público, manutenção. Cabia à Prefeitura fornecer o terreno, mesmo que fosse necessário comprar e doar. O FECE gerou, como referência e através de seus participantes, o Fundo Estadual de Construção Universitária, para a construção da Cidade Universitária. Seu funcionamento seria semelhante ao FECE, e teve a participação de Hélio Duarte, ainda que por pouco tempo, sendo substituído por Paulo Camargo de Almeida.

Foi nessa época, final da década de 1950, que começa uma outra transformação na educação e que afetaria mais tarde a arquitetura escolar. O surgimento e desenvolvimento da idéia de sistema educacional vinculado ao planejamento da sociedade. A implementação de um planejamento econômico e desenvolvimentista substituiu as iniciativas feitas pelo Estado. Até aqui o FECE e o IPESP ainda atuavam com ampliações da rede física em função de necessidades locais (falta de salas de aula, reformas de prédios existentes, substituição de prédios obsoletos). O início da década de 1960 encerraria um outro capítulo na construção da rede física dentro da cidade de São Paulo. As análises feitas neste capítulo sobre projetos realizados fora da capital paulista tem por intuito demonstrar esse novo caminho, que mais tarde afetará também a produção de escolas dentro da cidade. Ainda no FECE os profissionais ligados à área de planejamento se deparavam com a aplicação do planejamento sobre o sistema de educação. Houve tentativas, em anos anteriores, de realizar um tipo de planejamento que fosse capaz de ordenar e criar um sistema de rede física capaz de atender às necessidades da educação e de criar um sistema de educação que atendesse às exigências das transformações profundas pelas quais passava a cidade de São Paulo. Em vários artigos e livros estão descritas as possibilidades e os sistemas que poderiam ser utilizados para esse fim, porém os meios ou não existiam ou eram muito precários, como vimos nos outros capítulos. Desta vez, porém tratava-se de criar um sistema mais amplo, capaz de gerir todo o sistema educacional, desde a rede física até a manutenção e operação do sistema educacional. 
Essa história excede os limites desta pesquisa. Pretende-se aqui destacar, porém, que é com o início dessa transformação que se define um recorte temporal a partir do qual há uma série de mudanças nos meios utilizados para expandir a rede física da educação na cidade de São Paulo.

Parte da definição de como deveria ser o planejamento escolar, o qual já estava de forma embrionária funcionando dentro do FECE, partiu de uma reunião internacional em Washington em 1958, a qual conferiu grande importância à aplicação de um planejamento sistemático ao sistema de educação pública. Os profissionais que atuavam dentro do Plano de Ação tinham contato com as decisões tomadas nessa reunião e suas recomendações. Entre outras recomendações havia uma que indicava a necessidade de criar um fundo autônomo para financiamento e produção sistemática de rede física.

Se de um lado havia definições realizadas internacionalmente sobre o planejamento escolar, o mesmo também ocorria especificamente com a arquitetura, através da União Internacional de Arquitetos (U.I.A.). Em março de 1963 foi publicada tardiamente a Carta de Construções Escolares da U.I.A. $^{63}$, uma vez que ela foi elaborada em 1958 e retificada em 1959. O texto contido na revista Arquitetura enumera também um conjunto de recomendações que pretendiam ter o maior alcance possível para a elaboração de projetos de edificações destinadas ao ensino primário. Não há observações sobre aspectos construtivos ou sobre questões dimensionais, pois como o próprio texto revela não seria possível fazer uma carta contendo esses aspectos "dada a diversidade dos problemas considerados, a multiplicidade de condições humanas, econômicas e geográficas, considerando a evolução rápida das técnicas de ensino, assim como da construção (...)" ${ }^{, 64}$.

O conteúdo da Carta em muito se assemelha aos vários aspectos das propostas aplicadas nos projetos de escolas realizados desde o final da década de 1940 em São Paulo. Em alguns artigos descreve-se recomendações muito semelhantes como o levantamento das

\footnotetext{
${ }^{63}$ Arquitetura (9): 44-48, março 1963.

${ }^{64}$ Arquitetura (9): 44, março 1963.
} 
necessidades para elaboração de um plano escolar ou o estabelecimento de critérios para a distribuição das escolas. O critério de raio de alcance entre a escola e a residência do aluno é um aspecto que ocorre tanto na Carta quanto em alguns textos e entrevistas feitas nesta pesquisa. Preocupações com a escala, conforto, monumentalidade, insolação, ventilação, entre outros, ocorrem de forma semelhante tanto na Carta quanto nas fontes aqui utilizadas.

As semelhanças se estendem até a setorização em três grupos funcionais (unidade pedagógica espaços comuns e serviços administrativos), que é uma proposta que estava em desenvolvimento desde a década de 1930, mas que se consolida como prática de projeto na década de 1940 e 1950, e continua a ser utilizada nas décadas posteriores.

Ao que tudo indica as recomendações da Carta não possuem uma origem específica, se assemelhando muito mais a uma reunião de práticas que estavam em uso em vários países. Ou seja, nela não estaria a origem das práticas realizadas nas escolas públicas em São Paulo, ainda que tanto os arquitetos que atuavam dentro da prefeitura, quanto aqueles que foram contratados pelo governo do Estado tinham acesso a publicações internacionais. Nesse sentido é possível afirmar que os profissionais que atuavam na realização dos projetos de construções escolares estavam perfeitamente sintonizados com o que ocorria em outros países. Eduardo Corona participou de uma reunião da Comissão da UIA que tratava desse assunto, na década de 1960.

O Instituto de Previdência do Estado de São Paulo (IPESP) realizou, no início da década de 1960 também, um importante trabalho de ampliação da rede escolar. Foi tomada a decisão de investir o seu capital em imóveis. A construção de escolas pelo IPESP permitiria ao estado alugar essas edificações e assim o IPESP teria o retorno do capital investido e o estado conseguiria ampliar a rede física de escolas mais rapidamente. Apesar de não ter realizado projetos na cidade de São Paulo, a iniciativa do IPESP permitiu a muitos arquitetos desenvolver outras possibilidades ligadas à arquitetura escolar e assim influenciar as soluções adotadas nas escolas locais. 
Essa forma de realizar construções escolares trouxe a oportunidade, para vários arquitetos de São Paulo, de apresentarem propostas baseadas em uma arquitetura que já estavam desenvolvendo em seus projetos para clientes particulares. Foi o caso de João Batista Vilanova Artigas que, junto com Carlos Cascaldi, foram chamados para apresentar soluções para escolas, as quais terminariam por influenciar significativamente uma geração de arquitetos. Os projetos em questão são os ginásios de Itanhaém e Utinga. Estes projetos inauguraram tanto uma forma de contribuição dos arquitetos de São Paulo para o problema do edifício escolar como um modelo de arquitetura que culminaria anos mais tarde no plano do edifício da Faculdade de Arquitetura e Urbanismo da Universidade de São Paulo. Havia uma outra preocupação presente nesses projetos, e que era o desejo de criar edifícios que, de alguma forma, tivessem uma permeabilidade espacial interna.

\subsection{Os novos caminhos da arquitetura escolar}

A Comissão de Construções Escolares da Prefeitura permanece em funcionamento com esse título mesmo depois das iniciativas públicas do governo do Estado, com o plano de Ação, o que mais uma vez revela que os projetos de escolas feitos em ambas as esferas adotam caminhos diferentes. Até o final da década de 1950, os projetos realizados pelos arquitetos dessa Comissão pouco diferiam da prática projetual exercida desde 1949, quando tem início o segundo Convênio Escolar. Como já foi dito foram feitas algumas alterações em alguns elementos arquitetônicos. Outros programas são agregados às escolas, como ginásios esportivos, e outros elementos arquitetônicos que não eram usados nas escolas, mas que eram práticas comuns em outros projetos. Essas inovações foram introduzidas paulatinamente, e, de uma maneira geral, a composição arquitetônica permanece muito semelhante. Podemos afirmar que foram feitas algumas atualizações. Permanece ainda a preocupação dos arquitetos em justificar com critérios os mais científicos possíveis as soluções adotadas nos projetos. É preciso lembrar que os profissionais que atuavam no final da década de 1950, na Comissão, 
não eram os mesmos que tinham participado dos primeiros anos da $\mathrm{CE}$, mas eram de uma geração subseqüente e compartilhavam ainda essa prática.

Ou seja, algumas mudanças sutis, mas de modo enfático, começavam a ocorrer dentro dos projetos feitos pela Comissão de Construções Escolares.

O Instituto Municipal de Crianças Surdas, cujo projeto já foi citado, possui certas características que começam a distanciá-lo dos demais projetos de escolas. O seu desenho estava pronto em 1959 e em 1961 o prédio já estava construído, executado pela Sociedade Construtora Heleno e Fonseca S.A., no bairro da Aclimação (figuras 42 e 43). O inusitado programa, que ainda não havia sido enfrentado pelos arquitetos da Comissão de Construções Escolares, ainda foi resolvido dentro da lógica de uma composição aditiva por zoneamento funcional. Porém, as formas finais dos volumes que compõem o prédio possuem uma densidade diferente do que era feito até então: os planos das fachadas começam a ter certa independência do volume que elas definem. Os muros de pedra situados no nível mais baixo do projeto e as superfícies da fachada oeste denunciam um novo caminho, que no caso de Roberto Tibau, seria explorado mais ainda no seu projeto para a Escola Municipal de Astrofísica, da qual falaremos mais adiante. A superfície dessas empenas, sejam cegas ou iluminadas, ainda não correspondem totalmente à aplicação do conceito de uma arquitetura definida pela estrutura construtiva, mas estão no limite, como revelam as figuras, em que é possível verificar que os elementos que aparentemente dão suporte ao volume tem uma dimensão que pretende conferir-lhes uma presença mais incisiva na composição arquitetônica. Também desaparece a preocupação em posicionar as salas de aula para uma única orientação, que havia sido uma forte referência nos projetos feitos desde 1934. 


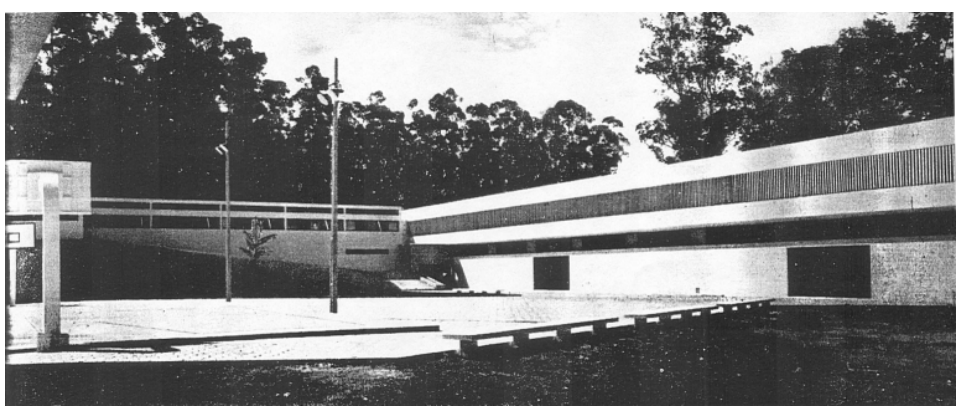

42

Instituto Municipal de Crianças Surdas

Vista da fachada oeste, com os quebra-sóis de fibrocimento; à esquerda da imagem as salas de aula

Fonte: Acrópole (272): 277, julho 1961

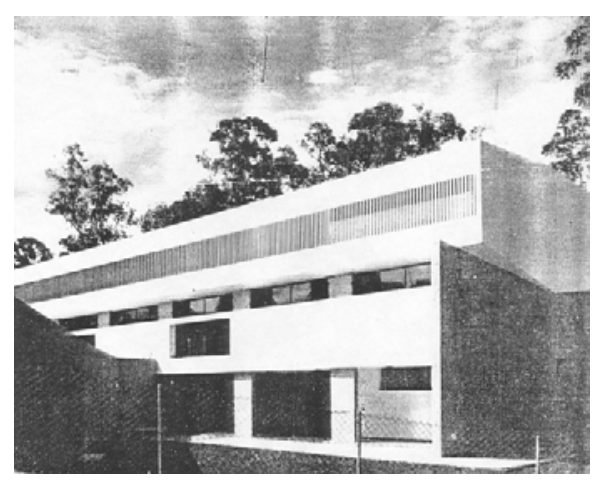

43

Instituto Municipal de Crianças Surdas

Vista do setor destinado ao pré-primário Fonte: Acrópole (272): 277, julho 1961
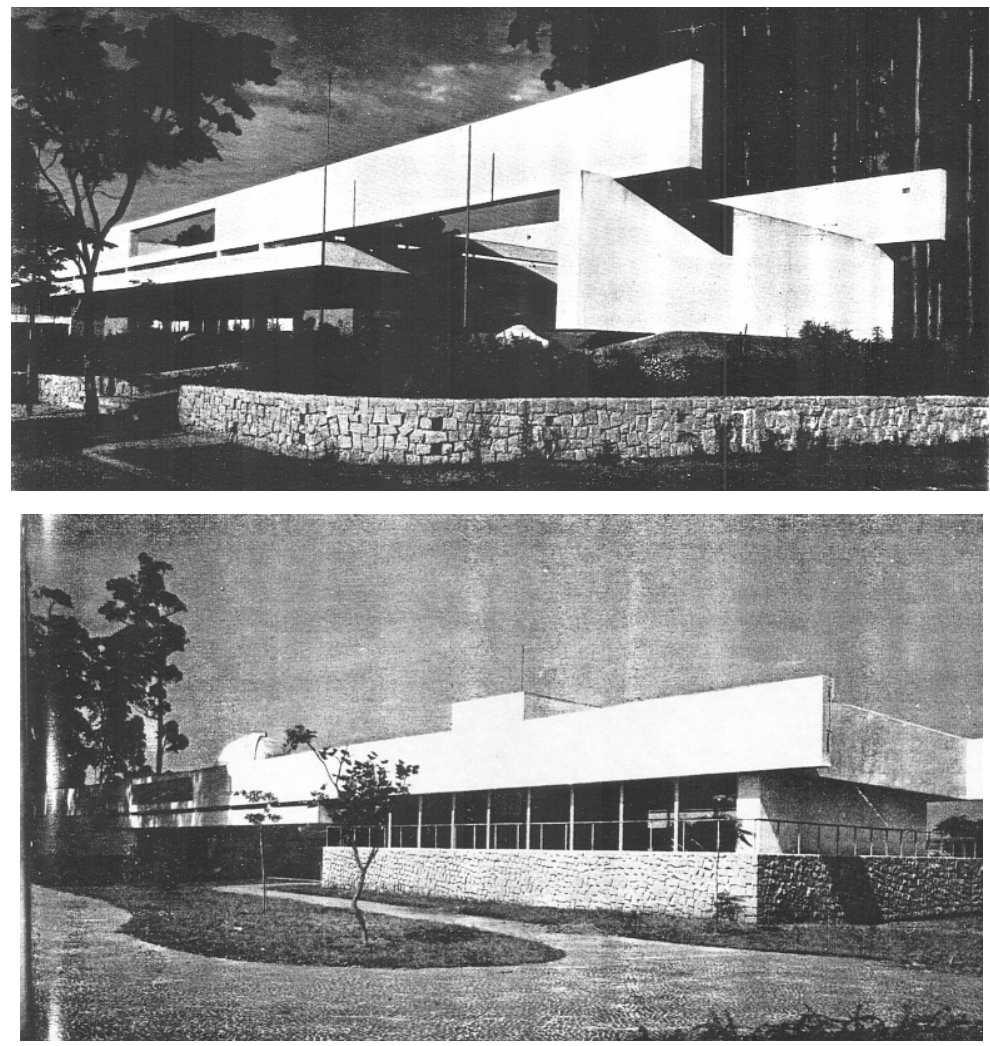

44

45

Escola Municipal de Astrofísica - São Paulo, SP, 1962.

Autor: Roberto Tibau.

Execução: Masetti \& Mariano Ltda.

Fonte: Acrópole (282): 181-183, maio 1962.

Em 1962, Roberto Tibau faz um projeto que pode ser considerado o mais diferente de todos, e com ele pode-se considerar que se encerra um ciclo de construções escolares municipais, no que se refere à arquitetura: o projeto, que foi construído, da Escola Municipal de Astrofísica, ainda existente, dentro do Parque do Ibirapuera (figuras 44 e 45). No mesmo 
parque, Eduardo Corona, que também participara da CE, fez o projeto do Planetário, também municipal, com sua forma peculiar e específica. Desaparecem os corpos longitudinais, com salas enfileiradas ao longo de corredores. Já não há mais um volume único, maciço, resultado de uma extrusão, ou uma somatória de volumes diferentes em uma composição aditiva. Também não há a típica relação parede, porta e janela, que desde 1936 ocorre nos projetos. A partir do segundo Convênio escolar podemos dizer que a esse trinômio acrescentou-se o piloti e a composição por adição. Em seu lugar há um conjunto de planos verticais e horizontais que reunidos em pontos de apoio visíveis criam um volume virtual, mas não fechado. A relação porta-janela-parede desaparece, dando lugar a uma composição por planos, os quais são definidos por sua dimensão e pelo material que nele predomina.

Se houvesse a necessidade última de definir uma linha ou corrente à qual o projeto está vinculado, podemos afirmar, por oposição, que esse desenho na verdade procura se distanciar do que foi feito até então, mais do que afirmar seu vínculo com alguma proposta pré-existente. Ainda que nele seja visível uma semelhança com a arquitetura de Mies van der Rohe, também dominada pela composição e sobreposição de planos, em que a técnica construtiva caracteriza as superfícies que irão finalmente definir os volumes. A diferença é que aqui não há a definição física de um volume e sim uma forma virtualmente construída no espaço.

No mesmo período, os arquitetos que participaram tanto da CE quanto da Comissão de Construções Escolares ainda projetavam escolas com uma configuração semelhante à do início da década de 1950. Em 1961 foi feito o projeto para o Centro Educacional de Santo Amaro (não foi possível confirmar a autoria, mas teve a participação ou de Hélio Duarte ou de Roberto Tibau). A disposição espacial ainda é semelhante ao que tinha sido feito nas décadas anteriores $^{65}$. Esse fato ressalta ainda mais a importância da inovação contida no projeto de

\footnotetext{
${ }^{65}$ Acrópole (314): 32, fev. 1965.
} 
Tibau para a Escola de Astrofísica: nele o autor se destaca do que estava em produção corrente.

Pode-se também considerar inovadora a solução adotada para o Centro Educacional da Mooca, de autoria de Rubens Cardieri. Ainda há a preocupação com o zoneamento funcional definido por volumes, porém há um desenho que busca uma unidade de desenho que se distancia bastante do que estava sendo feito anteriormente. Vejamos o texto que explica o projeto:

Nesta separação de funções procurou-se no entretanto, (sic) uma interpenetração espacial, numa busca constante de unidade arquitetônica. (CARDIERI, 1963, p.122)

É o que se pode constatar ao ver um dos blocos do projeto (figura 46).

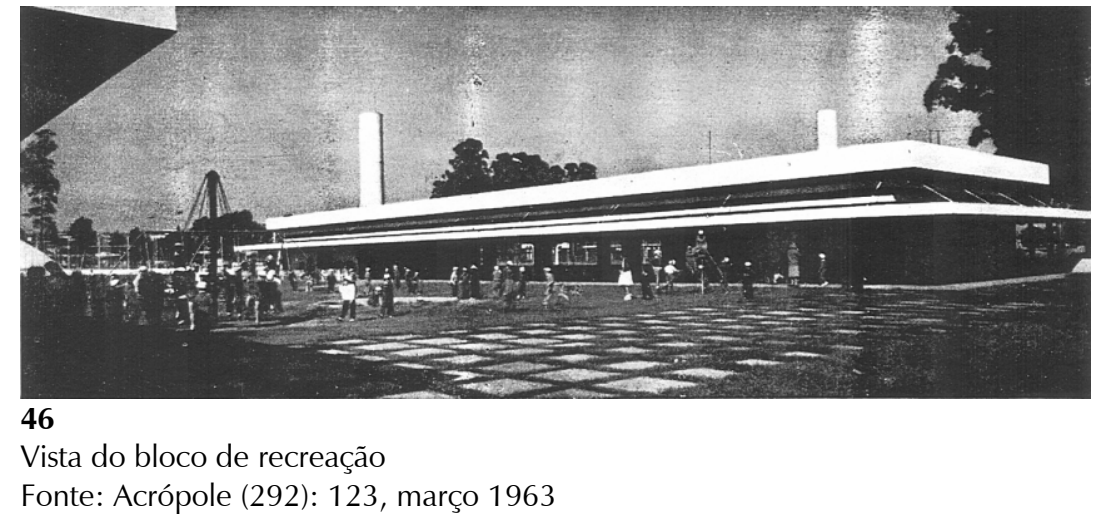

Nesse projeto também se configura a aplicação de um desenho em que a estrutura tectônica comparece com mais intensidade do que nos projetos de anos anteriores, com maior peso na composição de cada volume, como se pode avaliar na figura 47.

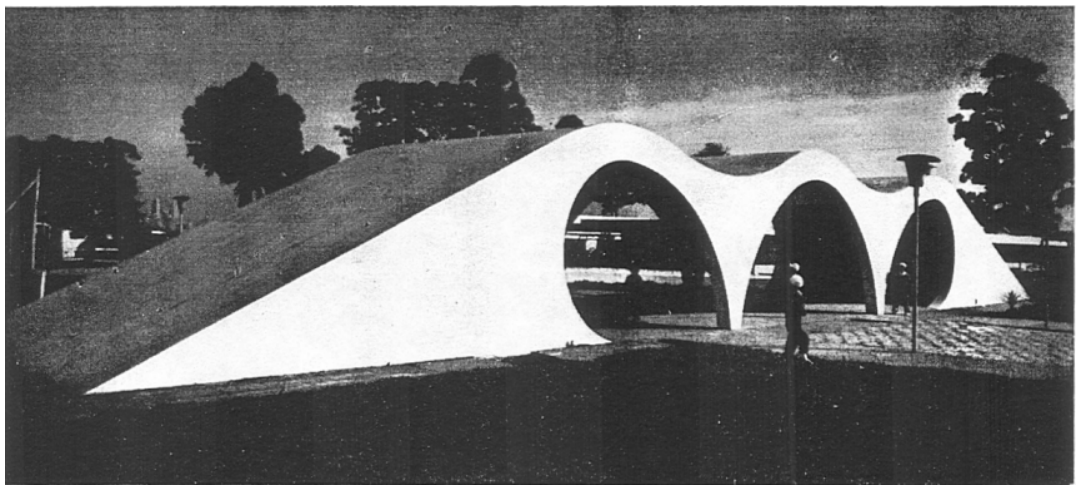

47

Vista da portaria do parque infantil

Fonte: Acrópole (292): 124, março 1963 


\subsection{A introdução de novos referenciais no projeto de escolas}

Pode-se afirmar que entre os arquitetos que participaram daqueles projetos ocorre uma resposta inovadora, feita tanto pelos profissionais vinculados à Prefeitura, quanto por profissionais ligados ao setor privado, como Artigas e Cascaldi. Esse momento pode ser definido como dos pontos de partida para um modo diferente de tratar a questão da escola. Os famosos Ginásios de Itanhaém e de Guarulhos (figuras 48 e 49) estão entre os edifícios desse momento. Além disso, até 1963, os grupos responsáveis pela produção das escolas públicas pelo Estado, com a participação intensa dos mais de 70 arquitetos contratados ao longo do Plano de Ação, geraram amplas discussões sobre o assunto, inclusive do ponto de vista da própria educação. No entanto, é possível afirmar que a partir dos projetos dos ginásios acima referidos e do projeto da Escola Municipal de Astrofísica, de Roberto Tibau, encerra-se uma fase inovadora da arquitetura escolar pública em São Paulo.

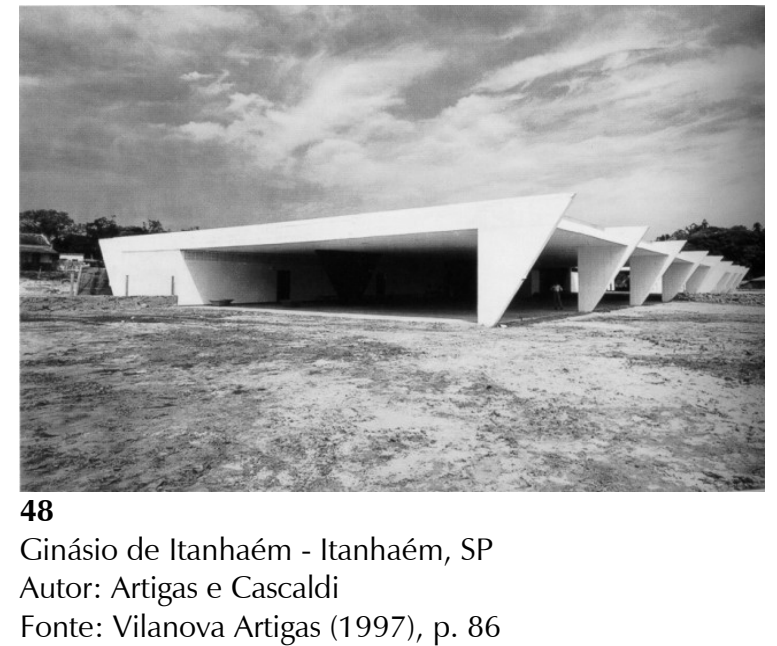

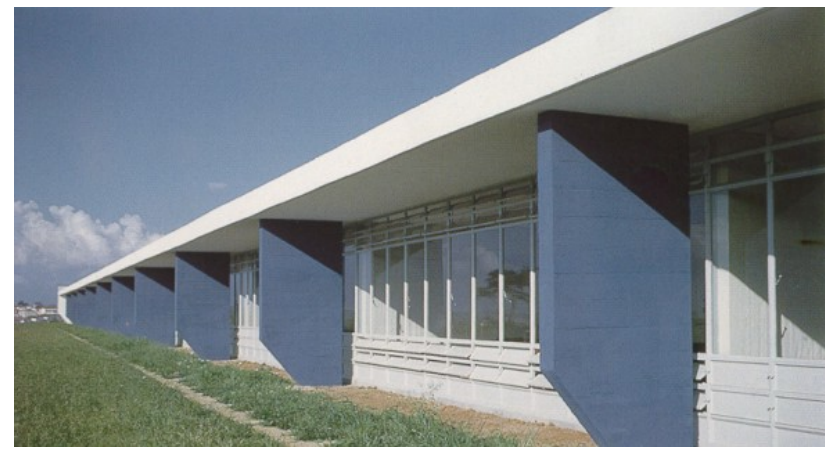

49

Ginásio de Guarulhos - Guarulhos, SP Autor: Artigas e Cascaldi Fonte: Vilanova Artigas (1997), p. 87

Sendo assim, a periodização adotada culmina com os seguintes eventos: a atuação do IPESP, a criação do FECE, Fundo Estadual de Construções Escolares, a participação de arquitetos que não são mais funcionários públicos, e por fim, a realização de projetos considerados inovadores e que foram assumidos como um modelo capaz de promover a socialização do espaço público edificado. Os anos que se seguem, após 1964, podem ser considerados uma outra etapa da história da arquitetura escolar pública paulista e do Brasil. 
Nesses projetos a arquitetura surge da aplicação de uma técnica construtiva, baseada na repetição de um pórtico: a seqüência de múltiplos de um mesmo pórtico, colocados a uma determinada distância entre si de forma seqüencial torna-se o modelo de raciocínio a partir do qual toda uma série de arquitetos de mais de uma geração irão propor projetos para edifícios escolares e para muitos outros usos também (ver figura 50).

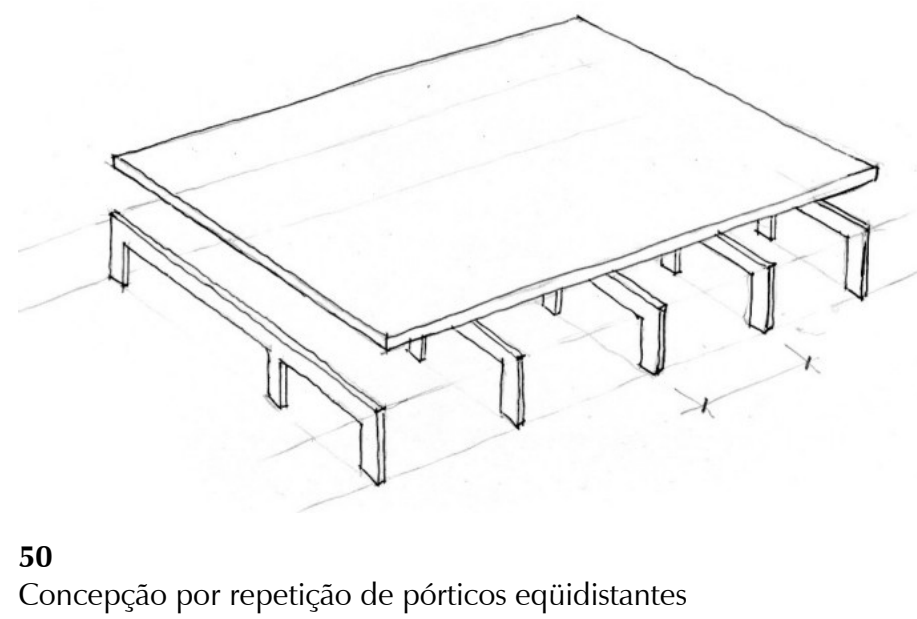

A origem da aplicação do pórtico na arquitetura carioca pode testar na escola do Conjunto Pedregulho, também citada por Kamita, mas a partir de outro enfoque. A escola primária do conjunto residencial do Pedregulho, projeto de Affonso Eduardo Reidy, construída antes de $1952^{66}$, possui grande semelhança com as escolas que estavam sendo produzidas pela CE. As volumetrias, a organização interna dos espaços e o programa similar demonstram a origem em comum desses projetos, visto que muitos dos profissionais que trabalharam na CE eram formados no Rio de Janeiro ou estavam a par das realizações de outros projetos de escolas fora de São Paulo. Há uma solução para a insolação das salas de aula, no projeto para a escola em Pedregulho (figura 51) que chama a atenção: como se pode verificar na imagem, as janelas das classes ficam recuadas do plano inclinado da fachada. A aparência final remete aos projetos feitos por Reidy em que a volumetria do edifício é definida por uma sucessão de pórticos, em geral de concreto armado, que se tornarão uma das principais referências da arquitetura feita tanto em São Paulo quanto no Rio de Janeiro a partir

\footnotetext{
${ }^{66}$ Arquitetura e Engenharia (23): 28-32, set. / out. 1952.
} 
do final da década de 1950 e a década de 1960. No caso da escola em Pedregulho não há um pórtico propriamente dito usado como sistema construtivo. O mesmo ocorre com a Escola Júlia Kubitschek, de 1951, de autoria de Oscar Niemeyer (figuras 52 a 54). A solução arquitetônica deriva de uma construção muito similar ao do pórtico de concreto armado, mas o sistema construtivo aplicado é apenas similar na sua forma. Porém a forma resultante indica um dos caminhos que serão trilhados por esse e por outros arquitetos no futuro próximo. A influência dessa arquitetura não será hegemônica, como atestam os projetos de Roberto Tibau e Rubens Azevedo, indicados neste capítulo.

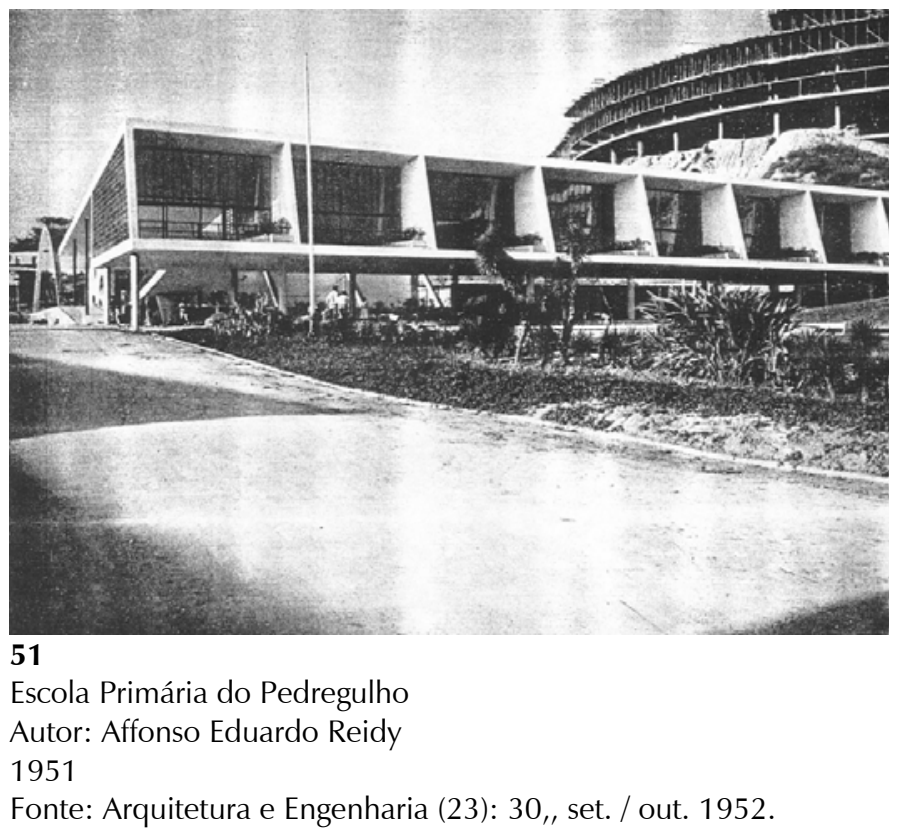

Foi efetivamente no Colégio Brasil-Paraguai (1953-1965) que ocorreu o salto fundamental para muitas das soluções arquitetônicas que seriam adotadas posteriormente por vários arquitetos, tanto no Rio de Janeiro quanto em São Paulo. Nesse colégio, que foi bastante publicado, assim como outras obras de Reidy, manifesta-se uma solução para a coluna, elaborada em forma de "V", repetida em seqüência como se pode ver na figura 55, a qual, na medida em que for aplicada em outros projetos, se tornará a referência principal para a elaboração do desenho do pórtico de concreto armado aparente. Essa coluna ocorre no projeto somente naquela fachada, mas o resultado plástico, que já havia aparecido na fábrica da Duchen, em 1950, será adotado em vários projetos de escola. Nos edifícios da Duchen foi 
usado o pórtico de concreto armado com três pontos de apoio, mas será no Museu de Arte

Moderna que essa técnica construtiva se materializará com a configuração proveniente das escolas citadas anteriormente, com dois pontos de apoio.

João Masao Kamita resume a relação dos projetos de escolas feitos em São Paulo feitos por Artigas e Cascaldi e a arquitetura de Reidy (figura 56), para o projeto de escolas (KAMITA, 2000, p. 28):

O volume virtual do ginásio assume a forma de um trapézio invertido, pois os elementos verticais de sustentação receberam a forma de um triângulo retângulo invertido. Tal configuração obedece à seguinte lógica: no momento em que ocorre a passagem da carga da laje para o pilar, a área de contato é maior; mas no ponto em que tais forças são transmitidas às fundações, a seção tende a diminuir progressivamente. A forma do prisma invertido havia sido experimentada por Niemeyer na escola de Diamantina, mas Artigas deve ao MAM do Rio de Janeiro (1953), de Reidy, a solução dos pórticos estruturais seriados. Trata-se, em ambos os casos, de extrair o máximo rendimento do esqueleto de sustentação, não só no sentido funcional, mas também no sentido plástico, pois essa variação da seção do pórtico tanto acompanha a lógica das solicitações de forças, quanto conforma um perfil elegante e delgado, cuja repetição define a modulação da planta e a volumetria do edifício. (KAMITA, 2000, p. 28)
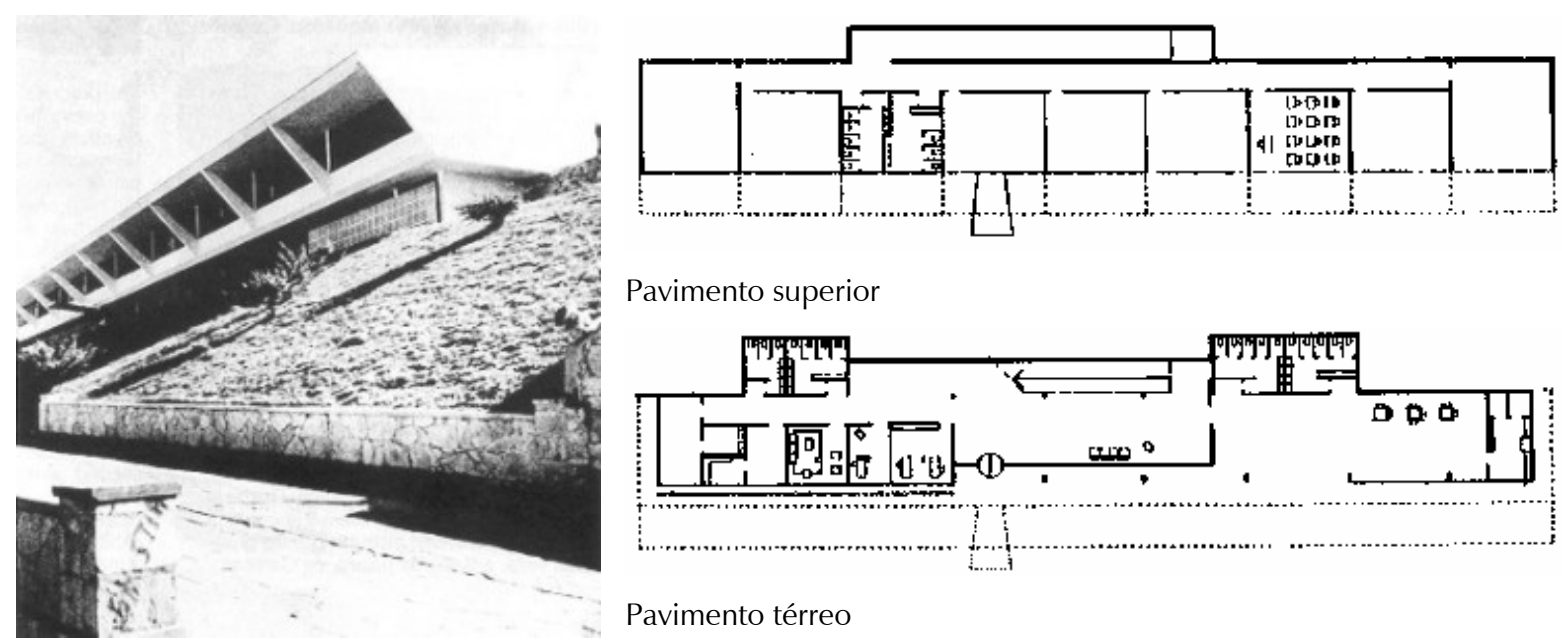

Pavimento superior

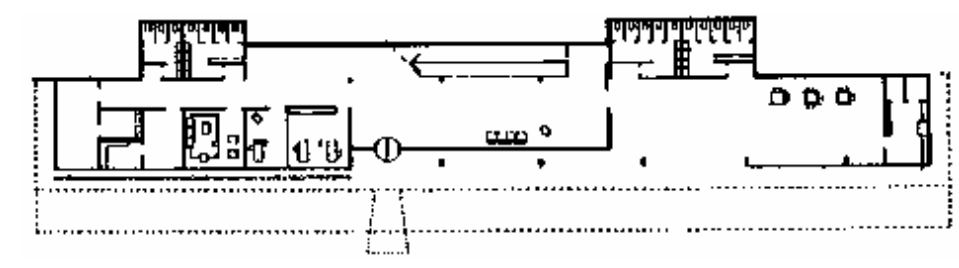

Pavimento térreo

5253

54

Escola Julia Kubitschek - Diamantina, Minas Gerais, 1951.

Autor: Oscar Niemeyer.

Fonte: BOTEY (1996), p. 172 e CAVALCANTI (s/d), p. 282-283.

Os projetos de escola desenvolvidos pelos arquitetos contratados pelo FECE e pelo IPESP serão em grande parte baseados no desenvolvimento das propostas feitas por Artigas, e foram analisadas pelo arquiteto Paulo Mendes da Rocha em artigo publicado também na 
revista Acrópole ${ }^{67}$, intitulado "Edifícios escolares: comentários". Nesse momento prevalece o fato de que aqueles projetos escolares eram o resultado do trabalho de uma novíssima geração de arquitetos, que tinham no concreto armado - em geral aparente - sua principal, senão única, técnica construtiva. Esses projetos foram em grande parte realizados fora da cidade de São Paulo, porém suas propostas tornaram-se uma referência fundamental para as escolas que foram feitas dentro da capital a partir de então. Por isso torna-se necessário avaliar os novos caminhos propostos naqueles edifícios.

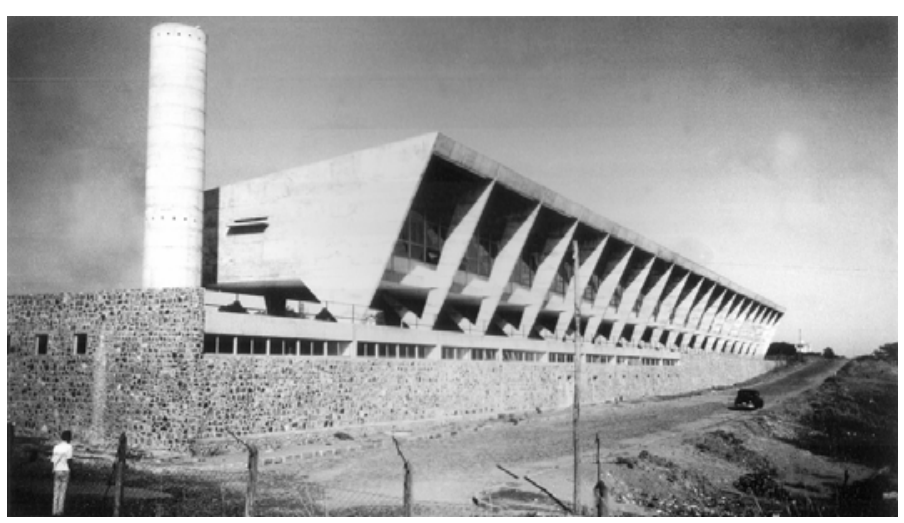

55

Colégio Brasil-Paraguai, Assunção, Paraguai

Autor: Affonso Eduardo Reidy

1952

Fonte: BONDUKI, 2000, p. 159.

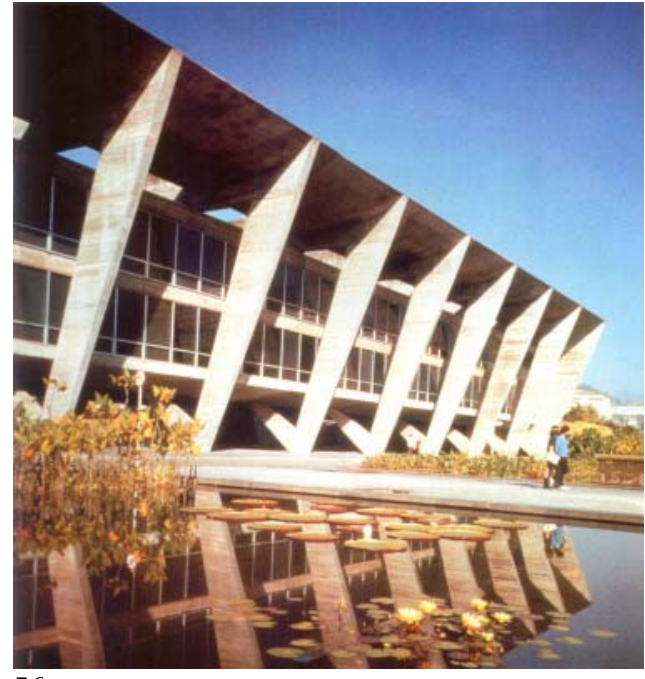

56

Museu de Arte Moderna, Rio de Janeiro Autor: Affonso Eduardo Reidy 1952

Fonte: BONDUKI, 2000, p.179.

Nesse período, em muitos dos projetos realizados durante o início do FECE, aparece, através da obra de Vilanova Artigas, uma característica arquitetônica que não ocorria anteriormente e que teve como seu principal precursor o arquiteto de origem alemã Mies van der Rohe. Nessa forma de conceber o projeto, a concepção por repetição de pórticos, citada anteriormente, caminha uma simetria espelhada horizontal, típica dos projetos do arquiteto alemão e que se tornaria uma das muitas marcas da arquitetura moderna a partir da década de 1920. O espaço interno, nesse caso, é resultante da sobreposição de dois planos horizontais e sua leitura pode ser feita como um espelho, que colocado horizontalmente reflete o chão no

\footnotetext{
${ }^{67}$ Acrópole (377): 35, set. 1970.
} 
teto. Dessa maneira o espaço universal, capaz de recepcionar, pelo menos teoricamente, todo e qualquer tipo de uso, sem limites verticais fixos, com enorme fluidez de circulação, é introduzido nos projetos de escolas (figura 57).
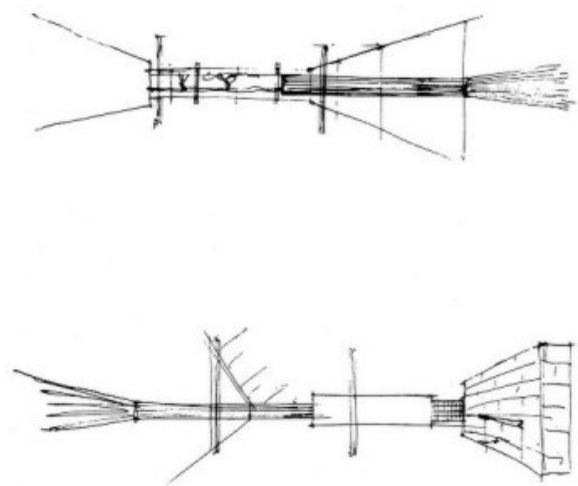

57

Simetria espelhada horizontal Desenhos de Mies van der Rohe Fonte: apud SORIANO 1996.

Os espaços internos no Ginásio de Itanhaém seguem esse raciocínio. No Ginásio de Guarulhos, porém, além da simetria horizontal (figura 58), Artigas insere uma série de desníveis, de um lado decorrência do relevo do terreno, e de outro lado uma conquista que possibilita uma riqueza espacial vinculada a alturas mais adequadas e específicas a cada um dos espaços internos à escola (figura 59).

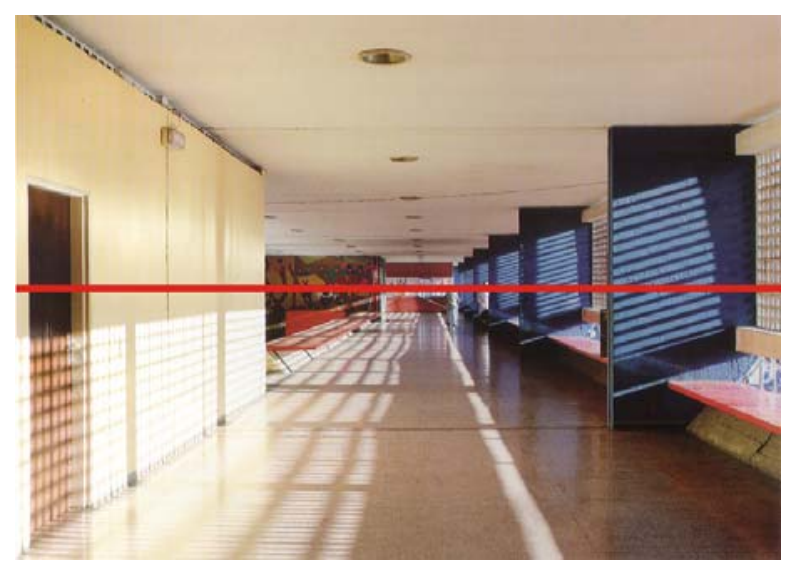

58

Visão interna do colégio. A linha em vermelho acrescentada na imagem indica o eixo horizontal da simetria.

Fonte: KAMITA, 2000, p. 76 


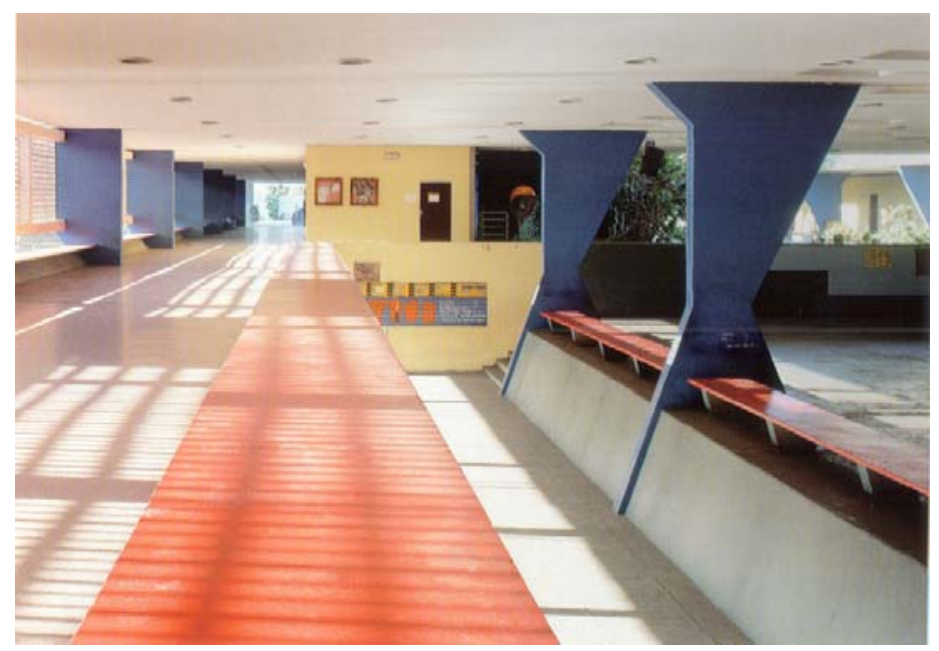

59

Visão interna do colégio, com as diferentes alturas para cada um dos três ambientes visíveis na imagem.

Fonte: KAMITA, 2000, p. 76

Ao explicar as soluções adotadas neste projeto, fica clara a definição da insolação nas salas de aula:

As salas de aula olham para o sul a fim de manter uma iluminação constante. Por outro lado, elas estão dispostas de forma a não sofrerem influência da natural agitação do pátio da frente, onde os alunos farão ginástica e jogos diversos. (ARTIGAS; CASCALDI, 1960, pp. 172-173)

Em outro artigo, publicado após a construção do edifício, há ainda mais uma justificativa para a inusitada orientação usada nas classes:

O prédio dispensa o uso de cortinas em salas de aulas, e tudo indica que a exposição para o lado sul, não terá inconveniência alguma - ao contrário pelo menos nas condições deste prédio. (ARTIGAS; CASCALDI, 1962, p. 156)

Encerra-se aqui toda uma série de soluções defendidas ardorosamente nos anos anteriores por arquitetos que acreditavam que a melhor, senão a única, insolação a ser adotada era a face norte, ou suas variantes, noroeste e nordeste. O que no caso da maior parte das cidades situadas no estado de São Paulo significa ter sol durante todo o dia, com algumas diferenças do ângulo de incidência entre o inverno e o verão. As razões que levaram mais de uma geração de arquitetos a enraizar nos projetos as implantações e posicionamento interno das salas de aula em fila com corredor de um lado apenas, com suas referências pedagógicas e 
oftalmológicas (pois a sombra seria prejudicial para a leitura) foram substituídas por outras referências. A unidade formal do edifício escolar no início da década de 1960 definitivamente caminhava em outra direção. 


\section{5}

Considerações finais 


\subsection{A historiografia consolidada}

As análises feitas por pesquisadores sobre o período escolhido para esta pesquisa, na cidade de São Paulo, que se inicia em 1934 e culmina em 1962, possuem uma referência em comum: as considerações sobre o tema da edificação escolar pública redigida por João Vilanova Artigas, em artigo publicado na revista Acrópole em 1970 e com um título simples "Sobre escolas..." $"$. O tom do texto se assemelha a uma aula, e é esse caráter didático, de simplicidade e de conclusões concisas e claramente organizadas que seduz o leitor e pode ter sido uma das causas da aceitação plena de suas afirmações sobre a arquitetura escolar no referido período.

Em todos os textos usados como fontes primárias, prevalece a separação clara e inequívoca do período analisado em três partes, e que se estende para o estado de São Paulo, à qual se adaptou também os capítulos desta tese. A periodização corrente está, além disso, separada em mais duas partes: uma que antecede a década de 1930, e que é o objeto de estudo do referido artigo e de uma dissertação de mestrado (WOLF, 1992), e o período posterior a 1962.

A divisão completa, portanto, da história da arquitetura escolar em São Paulo é feita em cinco partes: a primeira, pertencente à primeira República; a segunda ocorre entre 1930 e vai até o início da Segunda Guerra Mundial; o terceiro inicia-se com o fim da guerra e termina com o governo de Carvalho Pinto; e por fim, depois desse governo tem início um novo momento na arquitetura escolar. As divisões de caráter político não são superficiais, pois todos os trabalhos que foram influenciados pela pesquisa de Artigas tratam de edifícios escolares públicos, portanto o vínculo com a questão política está plenamente justificado.

Como se não bastassem os fortíssimos referenciais políticos e a própria guerra, a referida divisão histórica tem a seu favor o fato de que esses períodos também encerram, em

\footnotetext{
${ }^{68}$ Acrópole (377): 10-13, set. 1970.
} 
si, uma arquitetura que pode ser descrita como sendo no mínimo específica para cada momento no tempo, dentro do mesmo espaço, a cidade de São Paulo.

Neste trabalho pôde-se verificar que há uma outra periodização possível e que segmenta com mais precisão as características gerais que definem os projetos de escola pública, sem se ater totalmente à aparência física daquelas construções.

\subsection{Um referencial polarizado: a ciência e a unidade plástica}

Nas pesquisas realizadas foram identificados elementos e diretrizes de projeto que permitem vincular as arquiteturas, aparentemente isoladas, que foram segmentadas no tempo político, conforme uma determinada visão de suas configurações arquitetônicas.

No início da década de 1930, tem início o programa de construções escolares na cidade de São Paulo que tem como referência principal uma pedagogia que acreditava na renovação das práticas educacionais - o Escolanovismo - e que tinha como um de seus principais pensadores o educador Anísio Teixeira. Os projetos de escolas realizados nessa época possuem a indefectível marca do estilo denominado Art Déco e que se disseminou por inúmeros edifícios públicos, alcançando até mesmo edificações mais populares. Por Art Déco entenda-se o uso de uma organização plástica dos elementos que compõem a volumetria da edificação e das fachadas elaboradas segundo uma geometria maciça, para utilizarmos um dos critérios mais comuns de definição dessa arquitetura. Também é denominada de arquitetura proto-moderna, pois já contém alguns dos elementos que prevaleceriam na arquitetura moderna propriamente dita, ela possuía a peculiaridade de conter uma nova forma de fazer os projetos, o que inclui o uso extensivo de novas técnicas construtivas, o abandono do ornamento tal como era utilizado nas escolas do período anterior, e o uso de um programa amplamente baseado nas propostas da nova pedagogia. O referencial das escolas"platoon", também não pode ser menosprezado, e já foi citado em capítulo anterior. Há ainda duas importantes características, e são elas que permitem afirmar que o momento que se inicia na 
década de 1930, somente encerra seu ciclo no final da década de 1950. A primeira é o fato de que os projetos feitos a partir de então terão como uma de suas principais fontes de determinação do espaço da escola, principalmente das salas de aula, a aplicação de conhecimentos baseados em fontes científicas. Esse conhecimento permitiria ao autor do projeto determinar as formas, espaços, dimensões e hierarquias espaciais mais adequadas ao uso que aquele projeto deverá ser submetido. Isso se baseia na concepção de que um determinado conhecimento científico é mensurável e perfeitamente conhecido e, além disso, há ainda a forte convicção de que a ciência é, em si, um meio transformador da sociedade. Em mais de uma oportunidade Anísio Teixeira revela esse pensamento. O arquiteto José da Silva Neves, bem como outros responsáveis pelo programa de construção de escolas da década de 1930 também compartilham dessa visão.

Isto posto, os projetos realizados nessa época contêm as principais referências volumétricas e de implantação no terreno que serão amplamente utilizadas nas décadas posteriores: o posicionamento das salas de aula para a orientação de maior incidência de luz solar durante a maior parte do dia, ou seja, no caso da cidade de São Paulo é a direção norte; a colocação de salas de aula somente de um lado dos corredores de circulação; o agrupamento por afinidade funcional dos espaços internos da escola (administração, recreação e ensino); o uso de fórmulas matemáticas e materiais que garantam a qualidade acústica e térmica dos ambientes destinados às crianças; a criação de espaços de lazer de uso específico, possibilitados pelo uso do concreto armado, e sugeridos pela nova visão sobre o que é a criança.

O vínculo, porém, não ocorre de forma direta como, aliás, em todos os momentos da arquitetura escolar pública da primeira metade do século $\mathrm{XX}$. A renovação nos projetos das escolas não ocorre dentro de grupos que se mantém em contínuo contato, ou que pertençam a uma mesma instituição pública. Pelo contrário, se utilizarmos o critério de divisão temporal indicado por Vilanova Artigas e que ainda prevalece na maioria dos textos que tratam do 
assunto, poderemos verificar que as modificações na forma de fazer os projetos ocorre porque há grupos novos de arquitetos, provenientes de diversas origens. A extensão do trabalho da Comissão Executiva do Convênio Escolar parece corroborar essa visão: após o término do Convênio os principais profissionais, que iniciaram o trabalho em 1949 e 1950 já haviam saído, quando a então denominada Comissão de Construções Escolares, com outros profissionais, continuava a construir escolas no final da década de 1950 seguindo os mesmos princípios essenciais delimitados anteriormente. Exceção se faz notar quando Roberto Tibau, que havia sido integrante do segundo Convênio, projeta a Escola Municipal de Astrofísica em 1962.

Essa forma de renovação pode indicar que não há vínculos possíveis entre as arquiteturas das escolas da década de 1930 e aquelas produzidas na década de 1950. Isso é fato apenas em parte. O que se percebe é que, do ponto de vista da aplicação do conhecimento científico para determinar soluções arquitetônicas, a continuidade é visível. Além disso, aquelas características arquitetônicas citadas nos projetos da década de 1930 e início dos anos 1940 permanecem com intensidade nos projetos da Comissão Executiva do Convênio Escolar. Os depoimentos dos arquitetos do Convênio (Hélio Queiroz Duarte, Eduardo Corona, Ernesto Mange, Roberto Tibau, Aluísio Rocha Leão, entre outros) vão confirmar, alguns pessoalmente através das entrevistas, que faziam projetos tendo como referências conhecimentos provenientes da física, da psicologia, da sociologia, ou até mesmo de raciocínios matemáticos abstratos. Ou seja, apesar da renovação continuar a ser feita através de grupos distintos atuando dentro ou para o setor público que trata da construção de escolas, há uma continuidade não por contato ou influência pessoal: a afinidade com o conhecimento científico e o seu vínculo com a arquitetura provêm de outra esfera. No caso das escolas, em inúmeros textos, o uso desse conhecimento se presta não apenas para projetar o ambiente mais “confortável” ou "previsível" no que se refere ao seu comportamento térmico e ou acústico. 
Tudo indica que esses profissionais acreditavam que essa prática permitiria intervir na própria educação das crianças que estão ali dentro.

Todos os profissionais que aqui estão presentes acreditam ou acreditavam que a edificação escolar pode intervir, ou pelo menos contribuir indiretamente para a qualidade e para o alcance da educação que será exercida em seus espaços. Mas no caso do conhecimento científico, essa capacidade iria além, pois seria mensurável, ou, no mínimo, comprovável, visto que avaliar se e como um determinado espaço interfere na educação de uma criança não é uma prática consensual ou tampouco mensurável com precisão.

Portanto, podemos afirmar que há, em uma outra visão sobre o assunto, dois momentos principais em que podemos segmentar o período analisado: o primeiro, que se estende de 1936 a 1959, e o segundo que se inicia em 1957, aproximadamente, e se estende até depois de 1962.

O primeiro momento está impregnado pela presença da ciência, ainda que não como prática metodológica, mas sim como conseqüência do que é a ciência e da aplicação de alguns conhecimentos científicos, se estende de 1936 a 1959. Esse primeiro momento também possui características arquitetônicas semelhantes, ainda que a aparência visível dos seus edifícios e a volumetria do pré-guerra e do pós-guerra sejam realmente diferentes entre si.

O segundo momento revela um outro caminho, que trilha a mesma direção, porém de uma maneira diferente, se comparado ao primeiro: desaparecem dos textos e dos desenhos as explicações matemáticas e científicas. Desaparece a mensurabilidade do desenvolvimento infantil no projeto arquitetônico. Não que o interesse na relação com os aspectos pedagógicos tenha diminuído, muito pelo contrário: a relação entre educadores e arquitetos parece acentuar-se, pois a visão de que a arquitetura pode interferir de alguma maneira, e principalmente em escolas públicas, na educação é mantida com muito vigor, como pode se verificar nos textos e nos projetos. Ressalta um outro aspecto da arquitetura escolar, ainda que em projetos realizados fora do município de São Paulo, mas que irão influenciar os projetos 
feitos na capital paulista na década de 1960: a unidade plástica. Esse raciocínio, levado da maneira como foi desenvolvido pelos arquitetos contratados pelo governo do estado, substituiu as preocupações anteriores: o uso sistemático do pórtico de concreto armado repetido em uma seqüência com distâncias semelhantes entre eles criou uma volumetria que tudo abraça e contém. Se há algum vínculo com algum aspecto mensurável cientificamente do projeto, este também se desvanece sob a hegemonia da volumetria que domina pela sua unidade, tanto no que se refere à aparência quanto na técnica construtiva, pois nesse momento não é possível separar a arquitetura da sua estrutura.

Com isso encerra-se um período de intensa produção arquitetônica na cidade de São Paulo. Da admiração e sedução da ciência e da técnica, chega-se ao espetáculo da construção e dos espaços dela decorrentes. A arquitetura das escolas continuaria sendo considerada, nas décadas seguintes, um elemento fundamental na educação, não apenas como meio, mas como um fim em si próprio. 


\section{Referências bibliográficas}

ALENCAR, Meton de. Edifícios escolares para internatos. Rio de Janeiro: Imprensa Nacional, 1945.

ARTIGAS, João Batista Vilanova. Caminhos da Arquitetura: Vilanova Artigas. São Paulo: Cosac \& Naify Edições, 1999.

BAYEUX, Gloria Maria. Debate da arquitetura moderna brasileira nos anos 50. São Paulo, 1991. Dissertação (mestrado) FAU-USP.

BONDUKI, Nabil (org.). Affonso Eduardo Reidy. São Paulo: Editorial Blau; Instituto Lina Bo e P. M. Bardi, 2000.

Origens da habitação social no Brasil: Arquitetura moderna, Lei do Inquilinato e difusão da casa própria. São Paulo: Estação Liberdade; FAPESP, 1998.

BOUERI FILHO, José Jorge. Diagnóstico das edificações escolares. Potim: Prefeitura Municipal, 1997.

BOTEY, Josep. Oscar Niemeyer. Barcelona: Editorial Gustavo Gili, 1996.

Brasil. MEC. Ensino no Brasil em 1951-1954: ensino extra-primário. Rio de Janeiro: S.N., 1957.

Brasil. Diretrizes e bases da educação nacional: parecer da subcomissão incumbida de examinar as emendas do plenário ao... Rio de Janeiro: Diário Oficial da União, 1959.

BUENO, Belmira Oliveira. Associações de pais e mestres na escola pública do estado de São Paulo (1931-1986). Tese (doutorado) apresentada a Faculdade de Educação USP, São Paulo, 1987.

BRUAND, Yves. Arquitetura contemporânea no Brasil. São Paulo: Perspectiva, 1991.

BUFFA, Ester e PINTO, Gelson de Almeida. Arquitetura e Educação: organização do espaço e propostas pedagógicas dos grupos escolares paulistas 1893-1971. São Carlos: Brasília: EdUfscar; INEP, 2002.

CAVALCANTI, Lauro. Quando o Brasil era moderno: guia de arquitetura 1928-1960. Rio de Janeiro: Aeroplano, s/d.

CORRÊA, Maria Elizabeth Peirão; MELlO, Mirela Geiger de. NEVES, Helia Maria Vendramini. Arquitetura escolar paulista: 1890-1920. São Paulo: FDE, 1991.

; FERREIRA, Avany de Francisco; MELLO, Mirela Geiger de. Arquitetura escolar paulista: restauro. São Paulo: FDE; IMESP, 1998.

CZAJKOWSKI, Jorge. Guia da arquitetura Art Déco no Rio de Janeiro. Rio de Janeiro: Casa da Palavra; Prefeitura da Cidade do Rio de Janeiro, 2000. 
DUARTE, Hélio de Queiroz. Escolas-classe escolas-parque: uma experiência educacional. São Paulo: FAUUSP, 1973.

FERRAZ, Marcelo carvalho (org.). Vilanova Artigas: arquitetos brasileiros. São Paulo: Instituto Lina Bo e P. M. Bardi; Fundação Vilanova Artigas, 1997.

FRAMPTON, Kenneth. História Crítica da Arquitetura Moderna. São Paulo: Martins Fontes, 1997.

FREIXA, Jaume. Josep Ll. Sert. Barcelona: Editorial Gustavo Gili, 1979. 247 p.

FRY, Edwin Maxwell. A arte na era da máquina. São Paulo: Perspectiva, 1976.

Fundo Estadual de Construções Escolares. Relatório da situação da rede física escolar estadual do estado de São Paulo. São Paulo: FECE, 1972.

Fundo Estadual de Construções Escolares. Projetos de arquitetura escolar FECE. São Paulo: FECE, s/d.

GOROVITZ, Matheus. Os riscos do projeto: contribuição a análise do juízo estético na arquitetura. Brasília: São Paulo: Edunb; Studio Nobel, 1993.

HITCHCOCK, Henry-Russel. Latin American Architecture since 1945. Nova York: Museu de Arte Moderna, 1955.

KAMITA, João Masao. Vilanova Artigas. São Paulo: Cosac \& Naify, 2000.

LAMPARELli, Celso M.; RIVERA, Luiz L. Análise da situação educacional: ensino fundamental e médio no estado de São Paulo. São Paulo: Comissão Interestadual da Bacia Paraná-Uruguai, 1964.

MASCARO, Carlos Correa. Ensino normal no estado de São Paulo: subsídios para estudo de sua reforma. São Paulo: Faculdade de Filosofia, Ciências e Letras -USP, 1956.

. Governo estadual, orçamento e ensino. São Paulo: Universidade de São Paulo, Faculdade de Filosofia, Ciências e Letras, Secção de Publicações, 1959.

. Município de São Paulo e o ensino primário. São Paulo: Faculdade de Filosofia, Ciências e Letras -USP, 1960.

MINDLIN, Henrique E. Arquitetura moderna no Brasil. Rio de Janeiro: Aeroplano Editora, 1999.

MOACIR, Primitivo. A instrução e a república: reforma João Luiz Alves Rocha Vaz (19251930). Rio de Janeiro: INEP, 1944.

NEVES, José Maria da Silva. Desenho arquitetônico. Tese apresentada a Escola Politécnica da Universidade de São Paulo. São Paulo: Cupolo, 1943.

NEUTRA, Richard. Arquitetura social em países de clima quente. São Paulo: Todtmann, 1948.

NÓBREGA, Vandick Londres da (org.). Enciclopédia da legislação do ensino. Rio de Janeiro: s.n., 1952. 
OLIVEIRA, Beatriz Santos de. Modernidade oficial: a arquitetura das escolas públicas do Distrito Federal (1928-1940). Dissertação (mestrado) - FAUUSP, São Paulo, 1991.

ORNSTEIN, Sheila Walbe e BORELLI NETO, José (coords.). O desempenho dos edifícios da rede estadual de ensino: o caso da grande São Paulo. São Paulo: FAUUSP, 1993.

PAULISTA, Marilda Aparecida Soares Alcântara. O ensino público primário no estado de São Paulo, 1937-1945: transformações e continuidade. São Paulo, 1997. Dissertação (mestrado) FFLCH-USP.

PRUKS, Lia Reismann. Escolarização e instrução da população: o exemplo do estado de São Paulo. São Paulo, 1993. Dissertação - mestrado - FFLCH-USP.

São Paulo (cidade). Prefeitura do Município. Código de Obras Arthur Saboya - lei n. 3.427, de 19 de novembro de 1929. São Paulo: mimeo, 1929.

São Paulo (cidade). Prefeitura do Município. Código de obras Arthur Saboya. 1935.

São Paulo (estado). Directoria de Ensino e Directoria de Obras Públicas. Novos prédios para grupo escolar. São Paulo: Secretaria dos Negócios de Educação e Saúde Pública / Directoria de Ensino, 1936.

São Paulo (Estado). Grupo de Planejamento. Plano de Ação do Governo: 1959-1963: administração estadual e desenvolvimento econômico-social. São Paulo: Imprensa Oficial do Estado, 1959.

SAMPAIO, Maria Ruth Amaral de (coord.). São Paulo 1934-1938; os anos da administração Fábio Prado. São Paulo: FAU-USP, 1999.

SCHNEIDER-WESSLING, Eric. A construção escolar sob o ponto de vista de novos sistemas educacionais: formação de arquitetos e urbanistas. São Paulo: IAB-SP, 1969.

SEGAWA, Hugo. Arquiteturas no Brasil 1900-1990. São Paulo: Editora da Universidade de São Paulo, 1997.

SUZUKI, Juliana Harumi. Artigas e Cascaldi: arquitetura em Londrina. Cotia: Ateliê Editorial, 2003.

VASCONCELOS, Eduardo Alcântara de. População rural e acesso a educação no estado de São Paulo: análise da política pública. Tese (doutorado) FFLCH-USP, São Paulo, 1993.

XAVIER, Alberto et al. Arquitetura Moderna Paulistana. São Paulo: Pini, 1983.

WOLFF, Silvia Ferreira Santos. Espaço e educação: os primeiros passos da arquitetura das escolas públicas paulistas. Dissertação (mestrado) - FAU-USP, São Paulo, 1992.

Avaliação pós-ocupação e a arquitetura escolar na grande São Paulo: parâmetros para a qualidade do projeto. Encontro Nacional de Tecnologia do Ambiente Construído - Anais. Rio de Janeiro, 1995. 
TEIXEIRA, Anísio. Pequena Introdução à filosofia da educação: a escola progressiva ou a transformação da escola. Rio de Janeiro: DP\&A, 2000. 


\section{Periódicos e Arquivos}

Alguns dos projetos analisados foram obtidos exclusivamente nos periódicos. È o caso dos 68 galpões de madeira, que também entraram na classificação de escolas, ainda que fossem considerados na época como sendo construções temporárias.

\section{Periódicos}

AD Arquitetura e Decoração, São Paulo, n. 3, dezembro 1953/janeiro 1954.

AMADEI, José. Os problemas da escola. Engenharia Municipal, São Paulo, n. 14, p. 7-9, jul. / ago. / set., 1959.

. O que é o Convênio Escolar. Habitat, São Paulo, n. 4, p. 3, 1951.

ARTIGAS, João Batista Vilanova. Sobre escolas... Acrópole, São Paulo, n. 377, p. 10-13, set., 1970.

; CASCALDI, Carlos. Ginásio Estadual de Guarulhos. Acrópole, São Paulo, n. 259, p. 171-173, maio, 1960.

. Ginásio Estadual de Guarulhos. Acrópole, São Paulo, n. 281, p. 156-157, abril, 1962.

CAVALCANTI, Sandra. Carlos Lacerda e a Bolsa-Escola, in Estado de São Paulo, 27/02/2001, p. A2.

CARDIERI, Rubens César Madureira. Centro Educacional da Mooca. Acrópole, São Paulo, n. 292, p. 122-124, março, 1963.

Construções escolares: dois anos de atividade da administração Adhemar de Barros. Engenharia Municipal, São Paulo, n. 13, p. 5-8, abril/junho, 1959.

Convênio Escolar. Engenharia Municipal, São Paulo, n. 1, p. 17, out., 1955.

Convênio Escolar: projetos de Hélio Duarte e Eduardo Corona. Habitat, São Paulo, n. 7, p. 22-23, 1952.

DUARTE, Hélio de Queiroz. O problema escolar e a arquitetura. Habitat, São Paulo, n. 4, p. 4, 1951.

. Considerações em torno de um problema escolar. Acrópole, São Paulo, n. 314, p. $34-$ 35, fev., 1965.

Considerações sobre Arquitetura e Educação. Acrópole, São Paulo, n. 210, p. 236238, abril, 1956.

Ginásio estadual de Guarulhos, São Paulo. Módulo, São Paulo, n. 28, p. 1-6, junho, 1962. 
Ginásio estadual de Guarulhos, São Paulo. Acrópole, São Paulo, n. 259, p. 171-173, maio 1960; v. 281, p. 156-157, abril, 1962; v. 377, p. 18-19, set., 1970.

Ginásio Estadual de Utinga. Acrópole, São Paulo, n. 377, p. 20-23, set., 1970.

Ginásio em Itanhaém, São Paulo. Acrópole, São Paulo, n. 271, p. 241-243, junho, 1961.

Ginásio em Itanhaém, São Paulo. Acrópole, São Paulo, n. 377, p. 14, set., 1970.

HAHNE, Celso. Dez anos de atividades. Engenharia Municipal, São Paulo, n. 13, p. 9, abr. / mai. / jun., 1959.

JULIÃO, Maury Freitas. Atividades da Comissão de Construções Escolares. Engenharia Municipal, São Paulo, n. 2, p. 17-19, março, 1956.

KULTERMANN, Udo. As escolas de Richard Neutra. Habitat, São Paulo, n. 45, p. 44-47, nov. / dez., 1957.

MANGE, Ernesto Roberto Carvalho. Arquitetura escolar. Acrópole (197): 211-213, março 1955.

ROCHA, Paulo Archias Mendes da. Edifícios escolares: comentários. Acrópole, São Paulo, n. 377, p. 35, setembro 1970.

SEGAWA, Hugo. Arquiteturas escolares. Projeto, São Paulo, n. 87, p. 64-65, maio 1986.

SORIANO, Federico. Hacia uma definición de la planta profunda, de la planta anamórfica y de la planta fluctuante. El Croquis, Madrid, ns. 81/82, p. 4-13, 1996.

WOLFF, Silvia Ferreira Santos. História do ensino refletida nos prédios escolares. [Depoimentos]. Perrone, R. Jornal da USP, p. 10-11. agosto/1992.

\section{Arquivo}

Foram encontrados no arquivo da EDIF-PMSP um total de 140 projetos de escolas feitos dentro do período analisado. Acrescentaram-se mais 7 projetos identificados em periódicos, cujos desenhos não foram encontrados no arquivo. O trabalho engloba, portanto, um total de 147 projetos, que foram aqui organizados da seguinte maneira:

1. 33 projetos de escolas foram catalogados entre 1933 e 1934 pela Diretoria de obras Públicas da Secretaria de Viação e Obras Públicas do Governo do Estado. Essas escolas não foram incluídas na análise porque têm características que as incluem em um momento da história da arquitetura das escolas públicas que é anterior à periodização definida neste trabalho.

2. 24 escolas foram projetadas entre 1936 e 1947. Algumas delas são reformas de prédios já existentes, mas foram aqui incluídas, pois contém características pertinentes ao trabalho. 
3. 90 escolas foram projetadas entre 1948 e 1958. Algumas das escolas indicadas na tabela 3 não foram encontradas no acervo da EDIF-PMSP. Para isso foi necessário utilizar outras fontes, que neste caso foram os periódicos citados acima. Aqui também incluíram-se projetos de reformas com ampliações desde que tivessem algo que fosse pertinente à tese. 


\section{Anexo A}

\section{Depoimentos}


Entrevista

Roberto Goulart Tibau, arquiteto Novembro de 2000, em São Paulo - SP

(Mário Caldeira) Como começou o programa das escolas que o Hélio Duarte ajudou a elaborar?

(Roberto Tibau) Antes da gente começar a projetar, o Hélio que foi o pai mental desse negócio, ele convidou diretores, reuniões para discutir programa, mas era uma coisa lamentável. A contribuição que os "caras" podiam dar, praticamente eu não sei como é que o Hélio conseguiu sacar um programa novo. Inclusive era difícil de convencer eles, a respeito da inadequação de coisas que estavam superadas. Mas o fato é que se passou para um novo programa, que passou a ser a escola. Então foi como disse a Lina Bardi naquele artigo dela: "Finalmente nós temos uma escola aberta para crianças, clara arejada, limpa", uma coisa agradável de se estar ali. Enfim, ela fez um grande elogio à arquitetura escolar que tinha surgido ali, dentro do Convênio. Não sei se você chegou a ler.

(M) Li, saiu publicado na Habitat.

(R) Aquela parte do artigo da Lina, eu gostei muito. Foi feito por um arquiteto que conhece o assunto e sabe sobre o quê está falando. Falou com clareza, mas com simplicidade. Falou, falou mesmo. Naquela época isso ficou como uma preocupação constante dos arquitetos: o programa da escola. Como funcionava a escola. Uma coisa que tornasse a escola mais aberta. O programa aí não era uma coisa bitolada que não sai daquilo. Enfim, como conceituar o espaço do ensino, a sala de aula, o que era uma sala de aula, problemas de orientação, essas coisas todas que surgiram com a arquitetura. Naquele tempo não foi só a escola, acho que a arquitetura surgiu de um modo geral. Ela saiu de uma fase, vamos dizer assim, pioneira para uma fase de implantação mesmo. Então aí todo um processo de, não vou de dizer de adaptação, mas de reformulação em função de uma realidade, não só da realidade humana, social, mas uma realidade material também, de processo construtivo. Você não podia pegar uma escola projetada pelo Le Corbusier e projetar igual, fazer aqui, não ia funcionar. Uma casa a mesma coisa, não funciona. Então a gente teve que pegar essas coisas... Frank Lloyd Wright, qualquer um daqueles caras. Foi o trabalho do Lúcio Costa, do Oscar, do pessoal daquela época, que estão entre nós e aqueles. Eles que nos passaram a bola. E entre nós estava lá o Hélio Duarte que é um desses pioneiros. Ele foi, inclusive, um dos autores do projeto do IAB de São Paulo. Mas o Hélio tinha uma visão socialista mesmo.Na arquitetura tudo é indissociável. Então se ele pensa que a escola não é para meia dúzia de privilegiados, ela tem que ser uma escola econômica, ela tem que obedecer a um plano de produção do edifício escolar, e fazer escola para uma quantidade enorme de crianças, escolas que sejam de fácil manutenção. Então ele dava muita importância para essa parte econômica também. Você sabe que isso influi também na arquitetura, no desenho. Influi muito no desenho. Então por isso que a obra dele não apareceu tanto como deveria ter aparecido. Porque as acrobacias gráficas tendem a impressionar mais, não é? Então, uma arquitetura feita, assim como ainda a gente pensa que deva ser feita, ela realmente fica dentro desse capitalismo que a gente vive, dentro desse conceito do que é bom e do que não é, muito difícil. Eu acho inclusive, em um parênteses, que eu acho que nunca fui extremista, mas eu acho que o socialismo continua mesmo sendo uma proposta válida. Eu vi um cara comentando isso, há pouco tempo na televisão, talvez alunos de universidade. Estou convencido disso. Contudo tem uma experiência histórica, que levou a certos equívocos. Ela pode se aproveitar dessas experiências... Está dentro do assunto. Então se não houver isso, o quê que vai haver? Essa guerra civil, esse povo desesperado que está aí, essa juventude perdida, completamente alucinada. Vai ver as escolas públicas atualmente. Aquelas que nós queríamos fazer abertas, estão pichadas, destruídas, em franca decadência. Os caras ficam apavorados lá dentro. Tem medo de sair da escola.

(M) É verdade, eu vi isso.

(R) Naquela época, que nós começamos a fazer, já era um sonho pensar em fazer a escola mais aberta. Imagine agora. Mas eu acho que tudo isso continua vivo. Esse é um dos problemas que a gente tem. É que é difícil a gente discernir entre o que a gente tem de antiquado e de superado, e o que a gente tem de coisa que é válida ainda, que precisa ser transmitida. Precisa ser transmitida. Porque nós somos de certa forma um novo elo que se estabeleceu. Porque essa juventude precisa disso aí. Se não for por nós, nós temos esse compromisso educacional muito grande, não só na formação profissional, mas na 
formação geral da juventude. Geral, porque nós temos inclusive, modéstia à parte, um nível cultural que as famílias brasileiras não têm. Eles estão com a visão muito limitada, muito sacrificada. Então nossa função é muito séria. Agora tudo é interrogação atualmente. Eu digo isso assim de um modo geral, mas eu acho que precisaria novamente fazer o que o Hélio fez: voltar a pensar. Naquele tempo, como eu disse para você, era preocupação dos arquitetos o sistema de ensino, a filosofia educacional, a...

\section{(M) A pedagogia.}

(R) A pedagogia. Exatamente, obrigado. Então quando a gente dava um problema de projeto de escola na FAU, por exemplo, a gente fazia questão de fazer os alunos lerem Anísio Teixeira, aquele outro professor, Lourenço, daqui de São Paulo, e que tem um livro sobre a escola nova, para eles lerem toda aquela conceituação de ensino. Lerem o que falava Montessori, o que falava aquele escritor russo que também gostava de dar aula, embaixo de uma árvore, como é que era o nome dele. Que fez o "Guerra e Paz".

(M) O Tólstoi.

(R) O Tólstoi, um idealista. Enfim, mas o que vem dessa época eu acho que ainda é válido em parte, mas tem muita coisa nova. A humanidade evoluiu muito. E a gente, para sair desse beco que a gente está, a gente vai ter que utilizar armas contemporâneas, atuais. Não pode ter uma volta ao passado, assim tranqüila, não é bem isso. Então, eu acho que tudo isso cria uma expectativa muito grande. Hoje em dia, até é um pouco difícil você encontrar modelos de arquitetura. Modelos, vamos dizer bem assim. Coisas que você possa olhar e dizer "isso aqui é um troço bom". A não ser no aspecto formalístico, ou de eventualmente de alguma tecnologia, que a gente ainda não tem condições de implantar. Então essas revistas atuais são de uma utilidade muito duvidosa. Tudo isso tem que passar por uma revisão muito grande. Mas, como introdução era mais ou menos isso o que eu tinha para falar para você. O problema continua vivo. Que nós temos muita coisa a fazer em relação a isso, que é colaborar com o que está sendo feito. A minha confiança é que nós vamos conseguir, porque as gerações estão se sucedendo, mas esse processo está acontecendo e eu vejo que salvo algumas exceções, tem alguns que são mais, assim, com dificuldades. Quer dizer eles pegam como modelos, por exemplo, a construção mesmo que eles estão acostumados a ver aí na rua, imobiliária, e não conseguem sair disso. E repete. Tirar o cara disso é uma coisa. Mas eu acho que existe ainda material humano. E existem condições. Porque o Brasil é uma imensidão. Agora parece que o mundo está ficando cada vez mais escravizado. Viu o que aconteceu com a Argentina?

(M) Agora recentemente?

(R) É uma coisa terrível. Eu não sei em que nível esse problema tem que ser discutido. Mas há de ser essas coisas econômicas, dizer que o emprego diminuiu $0,23 \%$, aumentou $0,1 \%$ em relação a outubro do ano passado, não é mesmo? Mas o que a gente entende, também é importante o que você sente no seu interior. Eu continuo acreditando na arquitetura. Não tenho mais a mesma energia física, mas tenho o mesmo interesse, o mesmo entusiasmo, quase que eu diria uma palavra vulgar, a mesma paixão pela arquitetura, e eu acho que a juventude está herdando isso também, muitos jovens. Que é a base de tudo. Então, que haja mais diversidade no pensamento dos arquitetos, tudo bem, eu acho bom. Por exemplo o Hélio achava dessa maneira, como eu falei: econômico, tem que ser uma coisa simples, tem que ser uma coisa singela. Não se pode usar nenhum processo que encareça a obra, que fique mais complicada. Já o Corona achava que não. "Para quê fazer tanta economia se depois na concorrência eles vão deturpar tudo? Depois para a manutenção disso vai exigir uma verba, um gasto maior do que a gente ia gastar mais de saída". Ele falava: "Isso aí é mentalidade de engenheiro, economia de engenheiro". Mas não era, não era. O trabalho do Hélio Duarte, é o trabalho do beiralzinho, de Brasilit, protegendo a parede, das janelinhas pintadas de azul, as paredes brancas, aquela aproximação com a nossa arquitetura, nosso clima, das plantas generosas. Não são plantas mesquinhas. Implantações generosas. Naquele tempo ainda era possível fazer.

(M) Para lhe conhecer um pouco mais, quando o senhor se formou?

(R) Eu me formei no Rio. Quando eu entrei era EBA, Escola de Belas Artes, curso de arquitetura. Mas era um curso de arquitetura muito bom. Por ali já tinha passado o Oscar, muita gente. Eles tiveram inclusive o controle da escola um pouco antes, depois houve lá uma reviravolta e os modernos foram... 
Quando eu estudei metade da turma já topava arquitetura moderna, e outros ainda faziam aqueles desenhos tipo neoclássico, sombras e tal, aquelas coisas.

(M) Quando foi isso, mais ou menos?

(R) Eu me formei em 48, eu entrei em 44, por aí, 43 eu entrei, mais ou menos no tempo da guerra. Estava acabando a guerra, estava acabando o Estado Novo, havia uma efervescência de coisas. O "Cavaleiro da esperança" estava por aí, realmente uma nova esperança. Quando eu passei do primeiro ano para o segundo, já tinha sido criada a Faculdade Nacional de Arquitetura, FNA, que não existe mais, que atualmente é a da universidade do Rio de Janeiro. Faculdade de Arquitetura da universidade do Rio de Janeiro, que tem lá na ilha.

(M) Na Federal do Rio de Janeiro, lá no Fundão.

(R) Porque eu ia falar do Lúcio Costa, o Lúcio Costa foi diretor, no tempo do Ministério, e foi diretor. Aquilo foi uma festa, mas depois acabou. Mas mesmo assim meu professor de Grandes Composições, chamava-se Arquimedes Memória, ele é um arquiteto ilustre do Rio. Ele que tinha projetado os principais edifícios públicos, ministérios, troços assim. Estilo neoclássico mesmo. Mas ele não era assim como o Cristiano das Neves. Ele era um cara aberto. Ele, vamos dizer, aceitava bem. Eu me lembro de uma conversa que nós tivemos sobre o modulor do Corbusier. E ele falou do módulo na arquitetura grega.

(M) Que barato!

(R) Um barato mesmo! Um cara muito bom, viu? Eu fiz um projeto malucão no quinto ano, que era uma colônia de férias. Era um negócio de férias lá na baía de Sepetiba, um lugar bonito. Então invés de estar espalhando construção eu fiz compridão que acompanhava o desenho. Um edifício de vários pavimentos assim, e embaixo ia se descortinando as coisas, com o muro em cima, apartamentos com as pessoas. E ele topou e gostou. Parece que foi completamente contra a expectativa dele. Hoje eu não sei se eu faria aquele projeto. Mas é o que está pedindo. Porque você viu o que está acontecendo com esses prédios no litoral? Estão repetindo os mesmos erros que estão por aí afora. Não é verdade. Loteamento, aqueles troços. Estão esculhambando todas as praias.

(M) E depois, o senhor se formou em 48 mas já em seguida então entrou no Convênio escolar?

(R) Quando eu estava me formando, uma vez eu encontrei na Cinelândia, encontrei o Hélio Marinho, que era muito meu amigo, colega de turma, o Hélio Marinho ele participou daquele grupinho fez o Monumento ao Pracinha. E chegou a ser Secretário de Planejamento do Rio. Muito bom, viu. Ele estava conversando com o Gasperini, que também estudou lá, se formou lá na minha escola. É, ele veio da Itália. Ele fez uma parte do curso na Itália e no Brasil ele estudou lá. E muita gente de São Paulo. Porque aqui em São Paulo, a não ser que você entrasse na Politécnica. Mas mesmo assim, o curso de arquitetura da Politécnica tinha uma vantagem: que dava bons conhecimentos para o cara de engenharia, mas arquitetura o cara tinha que se fazer bem sozinho. Eu tive bons professores lá. Tive o Paulo Santos. Ora, tive professores muito bons na minha escola. Então entrar para a Politécnica eu ia desistir, porque eu não podia passar. Era muito duro. É fora da nossa área. Parece que arquitetura e engenharia mais ou menos a mesma coisa, mas é completamente diferente.

(M) Eu concordo.

(R) Você não concorda? Já pensou a gente ter que fazer um vestibular na Politécnica. Não dá nem para encarar.

(M) Aí o senhor encontrou com o Hélio Marinho na Cinelândia.

(R) Aí, olha, "Tibau, eu estava visando um emprego, que me apareceu uma oferta de trabalho em São Paulo, mas me apareceu um negócio que está me interessando mais, que eu quero ver se consigo". Naquele tempo ele estava fazendo um plano habitacional, não sei aonde lá para o norte, nordeste. Naquele tempo o Rio ainda era a capital federal. Órgãos assim, de caráter federal, ficavam tudo aqui. Enfim, ele tinha se desinteressado por aquilo. "Eu vou ver isso, talvez eu tope". Aí ele me deu o endereço da firma e tal. E eu cheguei em casa e falei: "Vou para São Paulo". Minha mãe ficou louca. A gente tinha família aqui também. Tinha uma grande parte da família dela aqui em São Paulo. Ela tinha umas primas que moravam ali na Cardoso de Almeida, umas solteironas. E eu fui morar lá com as solteironas e ela ficou mais tranqüila. E ficaram como se fossem minhas irmãs, eu me dava bem, eu 
me dava muito bem ali. E também eu não fiquei aí assim, perdido no espaço, por iniciativa da minha mãe. E "você sabe, você vai lá, você fica lá com elas, então você também paga um tantinho por mês, ajuda elas a manterem a casa, até você ter outra coisa". Ela me passou a cantada e tudo bem.

(M) Na verdade quem tinha sido convidado era o Hélio Marinho.

(R) Era o Hélio Marinho. Agora acontece que eu não cheguei a encontrar essa firma. Porque eu tinha um tio aqui em São Paulo, irmão da minha mãe, Fábio Goulart. Ele era um cara muito bem relacionado, engenheiro. Pessoal de uma grana da pesada, sabe. Os filhos dele são donos dessa coisa aqui de automóveis, desse prédio aqui...

(M) Prédio Dacon?

(R) É. Mas ele então disse: "Não, espera aí". Telefonou para um amigo dele, arquiteto. Se chamava Maciel Fleury de Oliveira. Ele tinha um escritório na Líbero Badaró. "Ele me falou que ele pegou um trabalho agora que ele está precisando de gente para ajudar, procura ele".

(M) Então o senhor nem foi procurar a firma?

(R) Eu dei uma procurada, não achei e desisti. Fui para essa, não é? Porque era arquiteto, não é? O cara é violinista, é legal. Ele é pai do Luisinho, do Luís Fleury. Conhece o Luís Fleury, lá da FAU?

(M) Sei, sei.

(R) É aquele ele mesmo. Era um garoto naquele tempo. Eu fiquei muito amigo do Maciel, porque ele tocava violino e eu também gostava de música. Então várias vezes eu fui na casa dele. Fazia um quarteto, tomava um chazinho. Me levou para ouvir toda a Paixão segunda São Mateus, de Bach. Era uma amizade muito grande. $\mathrm{O}$ trabalho que ele tinha pegado era uma construção. Construção de um conjunto habitacional na rua Santa Cruz. Sabe a rua Santa Cruz, que dá na Vila Mariana? Que desce ali, perto da igreja de São Judas? Aquela igreja esquisita que tem lá. Passa pela casa que foi do Warchavchik, que fica lá no meio daquele parque. Eu só via ela atrás do muro, mas eu tinha uma vontade de conhecer aquela casa. E por ali eu descia a pé e ia lá para o conjunto. Tinha que estar lá as sete da matina. Até as cinco da tarde. Almoçava, subia ali, ia comer em um barzinho, naquela rua que atualmente tem o metrô, Domingos de Moraes. Aí eu fiquei lá, trabalhando na obra. Mas aí a obra foi chegando ao fim. E eles acharam melhor me dispensar porque não tinha outro serviço para fazer no escritório também, sabe como é essas coisas. Aquela coisa, eu disse "Agora, já estou acostumado com São Paulo, já conheci minha noiva. E agora como é que eu vou fazer?". E fui falar com o tio Fábio outra vez: "Sabe, está acontecendo isso, e tal, acho que vou ter que voltar para o Rio". Ele disse: "Espera aí". Aí ele telefonou para um amigo dele que era presidente, diretor do Convênio. Era engenheiro, era muito legal. Ele também tem uma artigo.

(M) José Amadei.

(R) José Amadei. Esse cara é uma figura importantíssima na história do Convênio, porque ele aceitou todas aquelas propostas do Hélio, colaborou entusiasticamente, nunca criou nenhum problema, nem de ordem burocrática, nem de ordem técnica, nada. Um cara sensacional esse Amadei, viu. Porque o arquiteto tem muito disso. Se o Hélio tivesse pegado um cara chato lá ele não conseguia fazer o que ele fez. Não é verdade? Esse Amadei, na história real é uma figura chave. Então, ele participava com a gente. Eu me lembro, nós três num carro da prefeitura, indo para a Lapa, para ver o primeiro projeto que eu fiz. Que foi a escola, que foi a Escola de Aplicação ao ar livre. Eram feitas umas salinhas que estavam ligadas a salas ao ar livre e tal. Mas agora aquilo lá ficou tudo murado porque aquilo ali ficou uma zona de muita movimentação. Depois a FDE construiu uns blocos meio infelizes lá na frente, ficou uma coisa meio... E fomos nós três no carro conversando, e tal, para ver o terreno. Eu, o Hélio e o Amadei. Ele estava sempre ali, era um cara muito legal, viu? Mas também não se metia. Ele tinha uma posição assim. O Hélio era quem realmente dava as cartas e ele simplesmente apoiava, e o Hélio sempre gostou demais dele, sempre reconheceu. Então, o artigo que ele escreveu na época também é de interesse. Agora aumenta o interesse que possa ter para você, no conhecimento daquela época. Mas então, foi assim. Aí eu fui lá. O Hélio é que me recebeu. Eu só tinha visto ele uma vez no Rio.

(M) O senhor chegou a conhecê-lo no Rio? 
(R) Eu estava no Rio trabalhando como desenhista para o escritório do Oscar. Uma firma que chamava BBB, "Biscate, Biscate e Biscate", e cada um procurava biscate onde tinha, pelos escritórios, com canetinha Graphos.

(M) Isso já formado ou antes de se formar?

(R) Não, antes de me formar. Mas eu já devia estar no quarto ano, talvez. Não no quinto ainda, mas já no quarto ano. Aí, alguém me mostrou assim na outra sala. Tinha dois caras conversando na prancheta, e ele "Está vendo aquele cara de costa para cá, é o Hélio Duarte, é um grande arquiteto lá de São Paulo". Eu já conhecia mais ou menos, porque tinha uma publicação, um livro, naquela época, chamava Arquitetura no Brasil, Brazilian Architecture, uma coisa assim, que tinha projetos de vários arquitetos, e tinha coisas do Hélio também, tinha coisas do Zenon.

(M) É aquele livro do Mindlin?

(R) Eu acho que era do Mindlin. Eu sei que eu já tinha uma idéia assim, pelo projeto. Também não para conhecer muito porque estava de costas. Mas depois eu reconheci pelo jeitão, baixinho, moreno e tal. E o Hélio era uma figura fantástica. Foi talvez o maior amigo que eu já tive na minha vida. Inclusive eu freqüentava a casa dele. A mulher dele era uma senhora muito simpática também. Nós trabalhamos juntos várias vezes. Viajava muito. Foi para o norte, foi para Fortaleza. Ele era chamado para organizar escolas de arquitetura, para fundar escolas de arquitetura. Em Fortaleza, por exemplo, foi ele que fez. Fez outras também, daquela época. Ele tinha muita relação ainda com a Bahia também. Com Salvador. Ele esteve trabalhando lá. Conheceu lá o Anísio Teixeira. Eu acho que o Hélio estudou também na escola de arquitetura, no Rio. Depois é que ele foi para a Bahia. Depois veio para São Paulo. Tem até uma fotografia dele chegando em São Paulo, onde compareceram vários arquitetos, inclusive está lá o Artigas. Aparece até o Maitrejean, novinho ainda.

(M) E seu trabalho no Convênio? O senhor entrou e já começou a fazer escolas?

(R) Aí, foi assim: "Está bom. Então você vai ficar com o pessoal para obras, por algum um tempo, vamos fazer uma experiência". Tinha um projeto do grupo escolar rural Butantã, que tinha um programa todo especial, criação de bicho da seda. Era para crianças que fossem trabalhar na agricultura. E pediu: "Desenvolve esse projeto para mim". Aí eu fiz. As fachadas, plantas, cortes. Alterei um pouco a planta no que precisava, dando uma ajeitada. Enfim, está lá até hoje. E ele mandou construir. [...]. Ele topou, gostou. Então eu fui ficando. Aí depois, o primeiro projeto que eu fiz, que foi totalmente meu foi esse lá, da rua Fáustolo, da Lapa. Acontece que depois houve uma debandada do Convênio. Saiu o Corona. Saiu o Osvaldo Gonçalves. O Hélio já tinha saído. Porque logo que acabou o Convênio, passou a ser da prefeitura, o Hélio já foi saindo. E o Hélio nessa época já estava muito vinculado a universidade, a Cidade Universitária. [...].

(M) Quem era esse cara?

(R) Paulo Camargo. O traçado mesmo que está lá é do Paulo Camargo. Paulo Camargo é que fez todos aqueles convites, para arquitetos fazerem projetos lá. Cada projeto daquele tem um arquiteto que fez. Inclusive o Eduardo Kneese de Melo fez aqueles apartamentos, que eram tão bonitos.

(M) O senhor ficou só trabalhando para o Convênio ou também fazia outros tipos de escolas fora do Convênio?

(R) Não, ali nós fomos fazendo várias coisas. Depois eu fui trabalhar também no Senai. Nessa época, eu conheci a Lina Bardi. Eu dava aula no museu de artes, o Masp, no tempo que ainda era na 7 de abril. Tinha lá um curso de desenho de arquitetura, que eu colaborava. E lá que eu fiquei conhecendo os garotos que mais tarde vieram a ser ou pintores conhecidos ou arquitetos, artistas plásticos. Conheci também o Flávio Motta. Conheci o velho diretor lá, o Bardi. O Bardi era mais outra esfera. Enfim, tinha escritório com o Corona. Montamos escritório de arquitetura na rua Barão de Itapetininga. Fazíamos vários projetinhos. E foi indo assim, a vida do cara vai engrenando.

(M) Essas escolas do Senai, os programas delas eram completamente diferentes das escolas do Convênio, não é?

(R) Mas também na escola Senai a atuação do Hélio foi muito importante. Porque lá também ele encontrou um cara que era parecido com o Amadei, embora fossem muito diferentes. Mas era parecido porque topou de tirar o Senai daquela forma. Todas as escolas Senai até uma certa época tinham o 
mesmo desenho. Se você quiser ver uma escola típica é a que tem no Brás. É a que tem na Barra Funda, logo atrás da Igreja. Tem uma rua ali que tem uma escola Senai também. Mas as escolas Senai antigas, elas já tinham uma coisa que ele fez questão de preservar, o velho Mange, pai do Mange ${ }^{69}$. $\mathrm{O}$ Mange também eu conheci lá. Ernesto Mange. Foi nosso colega, trabalhamos juntos lá. Depois eu vou voltar a vaca fria, porque eu estava comentando o que aconteceu no Convênio escolar. Porque assim como nós introduzimos a arquitetura moderna nas escolas públicas, também introduzimos nas escolas Senai. E houve aí um intercâmbio intelectual, assim a nível de programa, do espaço da escola entre o Hélio e o Mange. Naquele tempo quem colaborava muito também com a gente era o escultor Fracaroli, Gaetano Fracaroli. Era um amigão do peito. A escultura que ele tem ali naquela praça que vai para o Jaguaré, tem uma praça redonda, ali perto do Ceasa, no meio tem a escultura do trabalhador, do operário. É uma beleza aquela escultura. Movimentada, é um operário mesmo. O Senai tinha um sistema disciplinar rígido, que tinha que ser mantido. Porque era uma coisa muito relacionada com a indústria. Você não pode deixar bagunçar a indústria. Porque o cara tem que pegar a sua ferramenta, guardar direitinho. Até o Paulinho uma vez, achou que aquilo ali era muito facistóide.

(M) O Paulo...

(R) Paulo Mendes da Rocha. Mas precisava ter uma coisa organizada naquela época. Então, por exemplo, um critério como aquele de fazer as oficinas dando para a rua, diretamente, a molecada, os moradores do bairro viam: "Vou tentar entrar nessa escola". A escola como elemento de atração. E ele dava muita importância para isso. E ele dizia, o velho Mange: "A escola Senai tem dois mundos, um é a oficina e o outro é a sala de aula. Os professores da sala de aula não se relacionam com os instrutores das oficinas. Os alunos detestam as aulas teóricas e estão interessados nas oficinas. E em uma ou outra coisa das aulas teóricas. Então nós temos que fazer que nas aulas teóricas eles se aproximem e viceversa". Então, criaram as oficinas, pequenos ambientes em que os instrutores davam aula, e programas também das disciplinas como matemática, geometria, também se relacionassem o mais possível com os trabalhos deles. E mais do que isso, o que ele queria é que a nossa escola criasse um elo espacial entre as salas de aula e as oficinas. Porque o aluno da sala de aula, descia, passava pela oficina e saía, e vice-versa. Que não ficassem salas de aula para cá e oficinas para lá, mas uma coisa integrada. Então nós fizemos várias experiências assim. E conseguia-se esse resultado. E fazia-se salas de aula em uma espécie de mezanino, as oficinas embaixo, resultado dessa proposta. Essas escolas estão muito bem conservadas. Eles cuidam bem do que eles tem, do patrimônio deles, até os jardins são bem tratados, tudo bonito. Não tem esculhambação. Eu fui outro dia ver uma escola que eu fiz do tempo da Conesp, Ermelino Matarazzo talvez, porque tinha que fazer uma ampliação grande. Quando eu cheguei lá, fiquei desesperado de ver o estado em que estava a escola. É uma esculhambação, viu?

(M) Esse seu trabalho no Senai era paralelo ao do Convênio ou foi depois?

(R) Em grande parte paralelo. Tinha um tempo, que eu tinha Senai, tinha Convênio e tinha a FAU ${ }^{70}$. Porque o Hélio também me convidou para dar aula na FAU logo que eu saí. Chego lá o primeiro cara que eu vejo sentado na beira assim é o Lúcio Grinover, com pose desafiadora. Ficamos muito amigos, amigos inseparáveis. Depois ele foi trabalhar no Senai também. Trabalhamos juntos no Senai. Quando eu fui para lá eu estava fazendo o projeto da escola de Santos, Escola de Construção Naval, na ponta da praia. Bonitinha a escola. Vale a pena ver. Aposto que até hoje é boa, mas há muitos anos que eu não vejo. Não é como geralmente ficam, acabadas. Isso aí foi o Senai, mas voltando ao Convênio escolar, eu estava dizendo que o pessoal foi saindo. E o Hélio foi saindo. Fiquei só eu como arquiteto.

(M) O senhor foi o último arquiteto?

(R) Agüentei firme lá. E aí foi entrando gente nova. Tiveram que contratar outros arquitetos. Então eu tive naturalmente a tarefa de passar para os novos colegas aquela coisa que a gente tinha pensado antes. Eu estabeleci um elo entre uma geração e outra. Mas também pouco depois disso eu saí, mas aí já tínhamos ido lá para o Ibirapuera, e também estava muito difícil de conciliar o horário de prefeitura com o horário da FAU. Porque a FAU, não parece, mas tem muita coisa, reuniões, e eu vivia com problemas, e ainda tinha o Senai. Então eu tive que ir me desvencilhando de certas coisas e eu preferi continuar com a FAU e deixar a prefeitura. Então pedi aposentadoria da prefeitura. Me aposentei.

(M) Rápido?

\footnotetext{
${ }^{69}$ Ernesto Roberto Carvalho Mange.

${ }^{70}$ Faculdade de Arquitetura e Urbanismo da Universidade de São Paulo.
} 
(R) Foi mais ou menos rápido. Uns dois anos depois que o Hélio saiu, eu saí também.

(M) E onde eram os trabalhos do Convênio, no começo, quando todos estavam juntos? Onde é que ficava?

(R) Na rua Gabriel dos Santos, ali na Pacaembu. Ela sai ali na estação Marechal Deodoro, do metrô. Tinha um colégio lá que chamava Ginásio São Paulo. Não estava mais funcionando lá e o prédio que e foi cedido para o Convênio escolar. E aí a gente fazia um futebolzinho lá. Nada como a juventude! A gente é tão irresponsável! Depois vieram outros arquitetos como o Arruda, o Aluísio Rocha Leão. Eu e o Arruda fizemos um conjunto educacional grande, em São Miguel Paulista.

(M) Essa é uma revista da Engenharia Municipal.

(R) Esse aqui projeto é meu, com o Aluísio da Rocha Leão.

(M) Chegou a ser construído? Núcleo Educacional para crianças surdas.

(R) Está lá na praça. Essa é a planta dele. O Rubens Azevedo também entrou nessa época. O Pitombo colaborou conosco no Planetário ${ }^{71}$. Eu, o Corona e o Pitombo. Morreu cedo. Está aqui, São Miguel Paulista, é esse aqui. É um conjunto bacana.

(M) São Miguel Paulista. Tibau, Pitombo e Arruda. Nessa época o Hélio Duarte já tinha saído?

(R) Já tinha saído.

(M) Achei interessante essa disposição.

(R) É porque são várias coisas. Tem o ginásio, tem o primário, tem as escolinhas. É todo diferenciado. E tem partes comuns: a biblioteca e o auditório servem para os dois.

(M) Como é que esses terrenos chegavam até vocês?

(R) Naquele tempo já era difícil arrumar terrenos, mas se arrumavam terrenos bons ainda. O terreno é grande.

(M) E do ponto de vista técnico construtivo tinha alguma imposição por parte dos engenheiros ou eram vocês que definiam? Como é que era decidido?

(R) Olha, a arquitetura e a engenharia estrutural no Brasil, mas no caso do concreto, porque era tudo concreto. Detesto estrutura de ferro. Mas de ferro só uma coisa ou outra. Se eu chegar a fazer vai ser uma coisa muito rara. Porque ainda se tem muita coisa para se fazer com o concreto. $\mathrm{O}$ ferro tende a ser uma coisa muito exibicionista. Tanto os calculistas, alguns deles, colaboraram muito com os arquitetos modernos para possibilitar a solução técnica das estruturas, como vice-versa os arquitetos alimentaram os calculistas de novas propostas estruturais. Então houve um entendimento muito bom, já desde essa época, entre engenheiros e arquitetos, principalmente nessa área estrutural. Instalações nem tanto. Eu acho instalações um pouco secundário. A estrutura está muito ligada a arquitetura. É o mais evidente. $\ddot{E}$ o próprio volume, a própria construção. Eu acho que dessa colaboração, que era importante para a gente poder fazer, houve um entendimento muito bom, mas só aí. Na parte de construção nem tanto.O engenheiro sempre foi difícil de lidar. O pessoal do CREA é terrível. Até hoje. Olha, era isso que eu tinha mais para comentar com você. No mais são detalhes. Mas você vê que a gente já procurava jogar com umas rampas. Porque agora está voltando a fazer rampa. O Artigas fez aquela rampa maravilhosa na FAU. O Corona fez lá na história. A gente já fazia rampa.

(M) Vocês já faziam. Esse grupo escolar de Vila Matilde, eu gostaria de ver sua opinião, em planta.

(R) Esse aqui procurou uma solução mais condizente com habitação, com as casas. Uma arquitetura assim que não ficasse estranho no ambiente. Mas foi uma experiência.

(M) Me chamou a atenção uma coisa: a disposição dos grupos de espaços, as salas de aula, a administração, etc, sugere uma certa comparação com aquele projeto que o Artigas foi fazer muito depois, em Itanhaém.

(R) Ficou uma plantinha até simpática, não é? Isso aqui tem uma continuidade.

(M) Parque infantil vocês fizeram muito no Convênio.

\footnotetext{
${ }^{71}$ Planetário do Parque Ibirapuera, em São Paulo.
} 
(R) Fizemos bastante.

(M) As escolas que foram feitas depois que o Convênio Escolar acabou, continuaram a ter arquitetos projetando.

(R) Ah, continuaram. Hoje é a EDIF lá.

(M) Transformou-se na EDIF.

(R) Transformou em EDIF. O pessoal da EDIF ainda me telefonou outro dia para a gente se encontrar, discutir, porque eles estão muito interessados nesse papo. Eles querem retomar também aquelas coisas. Eles estão interessados em fazer. Porque muita coisa que nós pensamos hoje, já se pensava naquele tempo, interessante e tal. Então, que coisa, não é? Não é porque foi uma continuidade, eles nem conheciam a gente. $\mathrm{O}$ que a gente pensava, curiosamente é o que eles pensam hoje. Isso foi transmitido para eles por outras vias. É o circuito de informação.

(M) E hoje tem outras pessoas estudando esse Convênio. Eu pretendo estudar mais que o Convênio, é uma coisa bem maior. Inclusive pegar aqueles projetos do FECE. Muita gente começou lá também.

(R) No tempo do DOP também foi feito muito. O DOP foi entre o Convênio e o FECE. E nós fizemos alguns projetos para o DOP também. Chamava a gente para fazer. Projetava no escritório.

(M) O senhor continuou projetando para o DOP?

(R) Eu fiz escola sem parar, a vida toda. Fiz mais de 500 projetos de escola.

(M) Só de escola.

(R) Só de escola. O Aluísio Rocha Leão falou: "No mundo inteiro, não tem um arquiteto que tenha projetado tanta escola como o Tibau". Ele falou "Pode procurar, fazer uma pesquisa, que não tem". Projeto meu mesmo, não é que eu tenho um escritório, pegava o projeto e entregava para alguém. Era eu que fazia tudo.

(M) Pagavam por salário ou por projeto?

(R) Não, era por salário. É mais ou menos o que ganham atualmente os arquitetos lá da FDE, mais ou menos, um pouco mais ou um pouco menos. 
Entrevista

Ernesto Roberto Carvalho Mange, engenheiro-arquiteto

\author{
26 de Abril de 2001, São Paulo - SP
}

(Mário Caldeira) Como começou sua carreira profissional?

(Ernesto Mange) Eu tinha pedido uma carta pedindo um estágio lá no, que era o escritório, que tinha contato com Le Corbusier e outros. E quando eu estava no, em 47, eu me formei em 45, na metade de 47 eu estava com um ano e meio de curso, veio a notícia de que havia ganho a bolsa. Dependia só de mim, ir ou não. Então, veja você, Mário, o dilema meu: ou fico aqui e termino esse negócio, depois tento novamente, não sei se ia conseguir ou não, ou, como se diz, o caipira fala, pega o jacaré, o rabo do jacaré quando ele passa. Não sei se lá na sua terra falam isso aí (risos). Aqui, o caipira paulista fala muito esse negócio aí, né: pegar o jacaré pelo rabo quando ele passa. Quer dizer, não deixar a oportunidade. Ou aquilo que diz o gaúcho: pegar o cavalo, quando passa você monta. Não vai deixar pra outro. Muito bem. No fim, debati, debati, e resolvi ir. E fui. Tive uns certos problemas lá, não me adaptei não. Não era aquilo que eu imaginava. Tanto assim que eu... na verdade freqüentei pouco tempo. Mas, tive a bolsa do governo francês. (...) Isso em 47. Saí aqui em outubro de 47 e voltei em 48. Mas eu não aproveitei muito o ateliê, por muitas razões, sabe? Primeiro que aquilo era uma torre de Babel. Tinha gente de tudo quanto é canto do mundo. E o velho Le Corbusier, ele já estava um pouco idoso. Ele não queria mais nada daquilo, sabe? $\mathrm{Na}$ verdade, quem tocava aquele negócio, era aquele chamado... era o arquiteto polonês, acho que era chamado Moczalski, que era o chefe da turminha, e que era chato e eu não me dei bem, era uma questão de empatia. Conversei uma vez ou outra com Le Corbusier, mas ele não dava pelota. Ele tinha quarenta caras lá, do mundo inteiro, jovenzinhos como eu, 25, 26 anos. Ele não dava muita pelota. Mas eu aproveitei muito sim, porque eu era provinciano e São Paulo naquela época era uma cidade muito bonita, simpática, orgânica, não essa porcaria que é hoje, claro, mas na verdade uma cidade muito limitada, né, oportunidades culturais, e tal.

(Mário Caldeira) Mesmo na década de 40?

(E) É, década de 40. Você tinha o Teatro Municipal, tudo bem... Tinha a Livraria Francesa já,. Tinha boas livrarias, não? Livrarias tinha boas. (...) livraria Martins, tinha várias livrarias. Até em uma delas eu encontrava várias vezes, (...) Monteiro Lobato. Você encontrava uns caras desse tipo assim. Era uma cidade, São Paulo era uma cidade interessante, porque estava começando a crescer naquela riqueza industrial, aquela coisa né?, mas ainda era muito provinciana, muito provinciana. Talvez se possa fazer um paralelo com certas cidades do, eu conheço algumas delas mas não conheço bem não, algumas sim, melhor, mas algumas cidades do Nordeste hoje. Está se desenvolvendo, não é? mas que não tem ainda aquela tradição. Tem um outro tipo de tradição, mas não tem uma tradição, digamos, de cidade contemporânea, industrial, etc, meio internacional com grandes hotéis, essa coisa toda. São Paulo já tinha, já recebia aqui companhias de balé, companhias de canto italiano. Tinha o Esplanada, que era logo atrás do Municipal, que hoje é a sede da companhia Votorantim, que era um hotelzão para a época. Tinha o Terminus que era um outro hotel (...). Enfim, São Paulo tinha os seus atrativos, mas na verdade era muito caipirona ainda, e eu então, apesar de eu ter caído numa França depauperada, ainda muito, dividida pela guerra, Petáin, de Gaulle, etc., e eu, aliás, já fui para lá com meu partido. Porque eu como bom descendente de franceses não podia deixar de participar de tudo isso aí. Eu sempre fui muito gaulista, sabe. Mas, eu percebi lá que em certos lugares ser gaulista era... e ripavam mesmo! A coisa era feia.

(M) Não tinha essa unidade de aceitação.

(E) Não. Lentamente o de Gaulle foi realmente se impondo, porque era uma personalidade forte. E depois que eu saí de lá, fui percebendo que, quando ele o de Gaulle foi eleito pela terceira vez, quando ele virou presidente, era realmente o grande líder da França. Chegaram até a mudar a Place Étoile para Place Charles de Gaulle. Não podia fazer uma homenagem maior. Aquilo é o coração de Paris, que por sua vez é o coração da França. Mas, eu aproveitei muito então, conhecendo pessoas, visitando e vendo galerias, (...) que dizer, fiz em alguns meses, com pouquinho dinheiro, (...) mas eu fiz uma boa viagem 
pela Itália, a Suíça toda, voltei pela Holanda, Bélgica. Mas isso não... eu conheci muita coisa. Então eu voltei com uma cultura, digamos, totalmente diferente daquela que eu tinha quando eu saí daqui. Mas eu voltei, isso em fins de 48. Aí, logo conheci o Hélio Duarte, o arquiteto Hélio Duarte que era, na época, o arquiteto-chefe do Convênio Escolar, e entramos aí no assunto arquitetura escolar, e arquitetura da época. O Convênio Escolar foi uma coisa muito bonita, viu. Você sabe o que é o Convênio Escolar, né? O Convênio se dava entre a prefeitura e o Estado para tentar fechar um pouco o vazio de escolas, a dívida que nós tínhamos com a sociedade, com as crianças paulistanas. E que não eram só criança paulistanas por terem nascido aqui, não, porque já tinha crianças do estado de São Paulo, de Paraná, de Minas Gerais, e já começava a vir de outros estados. Vinha do Nordeste.

(M) A migração do Nordeste...

(E) Sim. Nos anos 50 começou a coisa, depois foi se acelerando. O chamado "baiano", que é um termo pejorativo, mas que era uma maneira de caracterizar o não-paulista, vai, digamos assim, e olha, essa contribuição do Nordeste, do Norte - porque aqui, lá por Nordeste, entende-se tudo que está lá em cima, e existe uma distinção muito grande entre Nordeste e Norte - mas a contribuição do Nordeste e do Norte, pouco do Centro-Oeste - veio também gente, mas pouca, menos - mas foi muito grande, sem dúvida alguma, porque eu por estar em contato com o governo, por estar em contato com tudo isso aí, eu resolvo da seguinte maneira: cem, digamos, cem dos brasileiros que vieram vindo de regiões pobres, atrasadas, relativamente pra São Paulo, Paraná, etc, Triângulo mineiro, sul do MatoGrosso, eram regiões atrasadas sim, mas não só lá, por exemplo no norte de Minas Gerais era terrível, Governador Valadares...

[...]

(M) Em 51, o Convênio Escolar de que o senhor participou foi até 50 e poucos, mas o Hélio Duarte ficou lá até $1954 \ldots$

(E) Do Convênio Escolar eu participei 1 ano e meio só.

(M) Um ano e meio só?

(E) É que eu trabalhei que nem um desgraçado! Eu trabalhava seis horas por dia mas rendiam dez. Eu trabalhei que nem um louco.

(M) Você tem bastantes obras...

(E) Eu tenho um monte de obras feitas. Tenho de ginásio, de grupo escolar, tenho teatros infantis. Tenho um monte.

(M) Em só um ano e meio?

(E) Se é que um ano e meio, hein, Mário! No máximo, talvez menos. Um ano eu tenho certeza. Foi entre um ano e um ano e meio. Talvez um ano e dois meses, uma coisa assim. Eu entrei no Convênio Escolar pelo Hélio Duarte também em 1949 e saí em 1950, fins de 50, um ano e pouco. Só! Mas muita gente me conhece por causa do Convênio Escolar, porque eu produzi pra burro!

(M) E está publicado.

(E) Os caras faziam um projeto por mês, eu fazia um por semana. Eu era um doido completo. Eu ficava lá... Eu entrava de manhã cedo e saía às nove horas da noite. Era um tarado!

(M) Que pique!

(E) E depois eu cismei com algumas coisas.

(M) Com o que o senhor cismou?

(E) Eu cismei com uma coisa aí. Eu tinha estudado durante muito tempo as questões de, eu vou pôr aqui, aclaramento no ponto $\mathrm{P}$ [ver desenho anexo], vou chamar assim. Questões de iluminação natural. Aí eu comecei a me interessar muito por esse negócio, porque até então e até hoje inclusive se tornam as janelas no feeling, por experiência, e elas obedecem muito mais a uma questão de necessidade estética, de partido, plástico, do que qualquer outra coisa. Depois se ficou bom ou se ficou ruim não tem muita importância. Bom, o ponto $\mathrm{P}$ está no chamado plano de trabalho, né?

(M) Isso aqui é um corte? 
(E) Isso aqui é um corte. Isso aqui é o sol. Muito bem. Quando você vai construir uma edificação você vai fazer normalmente, estou falando de uma maneira simples, normalmente você vai fazer então, vai colocar entre a abóbada celeste... O que é a abóbada celeste? É isso que nós estamos vendo aí, uma beleza. Abóbada celeste, ela tem bilhões de partículas que estão irradiando. E, que se queira ou não, elas dão o azul do céu. Então o Gagárin, lá pra cima, dizer que a terra azul não é novidade alguma. Eu achei sempre muito engraçado isso aí: mas é óbvio! O azul é simplesmente a decomposição da luz solar pela atmosfera. Muito bem. Mas isso não vem ao caso. O que vem ao caso é que quando você tem um ambiente interno aqui, aqui é o externo, você enfia uma divisória qualquer aí, que tem por função o quê? São as funções da parede, mandar embora o calor, mandar embora os homens maus, deixar entrar o ar, deixar entrar a luz, (...) em vez de ser uma caverna qualquer. Então você vai ter nesse ponto P. Isso aqui, é o ômega aqui, é idêntico ao ângulo sólido que recorta um pedaço da abóbada. Você vai receber aqui um aclaramento que é assim, um vetor $\mathrm{E}$, mas que você não vai utilizar, normalmente. Normalmente você vai utilizar a componente dele que é a normal ao plano de trabalho. Agora, é evidente que se eu estou assim eu vou utilizar essa componente. Agora se estou lendo assim eu estou utilizando ela em cheio. (...) Isso aqui é o teto, então normalmente eu uso o E, que é utilizado normalmente é igual ao E lá de fora, o E celeste. Mas eu comecei a estudar isso aqui.

(M) Durante o Convênio ou antes?

(E) Não, antes.

(M) Na graduação?

(E) Não, antes, não, não, isso aí foi em quarenta e..., antes de eu ir para a França. Em 46, 47, por aí, mais 46. (...) 6 meses para resolver essa integral. Eu levava essa integral pra turma da Poli lá de cálculo: "Ah, então tá, volta daqui a dois meses". Eu voltava. "Ah, mas não resolveu ainda"”. Aí um dia me deu aquele negócio maluco (...). eu tava..., de noite, acordei minha mulher, tinha filho pequeno, acordei toda a casa, aquele negócio, eu descobri que se eu fizesse uma substituição de uma variável, que era muito freqüente em cálculo, uma variável de uma expressão trigonométrica eu caía, acabava caindo numa daquelas expressões já resolvidas, integral. Aí eu resolvi a integral. E com isso então, eu tinha como calcular esse negócio aqui. Mas o cálculo disso era importante em que caso? Como eu estava dizendo, que era importante (...) o cálculo. Por exemplo, se você tivesse, como eu tive vários casos, (..) você tem uma fábrica, ou um negócio qualquer desses, em que você faz um lanternim, chamado lanternim. Quer dizer, você ilumina através de uma série de superfícies, (...) então o homenzinho tá aqui. Então você vai iluminar para o homenzinho trabalhar aqui. Não importa se ficou ruim ou ficou bom (...), mas ele vai trabalhar aqui. Quê que acontece? Na vertical aqui faz uma curva assim. Cada lanternim...

(M) De iluminação. Aqui tem mais iluminação, nesse ponto, aqui tem menos e pra lá vai diminuindo. Pra cada um.

(E) Em lux. Vai caindo. Aqui a unidade é o lux. E assim então você teria outra aqui. Então esse rabicho se somava àquele. Então na verdade a curva final era uma curva assim, com ligeiras deformações, evidentemente. Eu acho que dá pra entender. Tudo bem. O quê que aconteceu? Quê que acontecia? Como você ia dosar isto, e isto aqui também, evidentemente, com estrutura, e telha, etc. Isto e isto aqui. Vamos colocar aqui, vai. Esse $\mathrm{H}$ aqui. Quanto de iluminação que ia iluminar, inclinação. Tinha que usar eles todos. Eu, com essa brincadeira aqui eu resolvia, eu fazia o que eu bem entendia, porque eu sabia o que tava fazendo.

(M) Você chegou a conseguir usar isso em escolas ou nem...?

(E) Não, eu consegui. Agora, sabe o que acontece, é que eu peguei o fim da época daqueles, acho que você nem conhece, que chamava-se ábacos. Porque a gente não tinha esse negócio de... Então o quê que tinha? Tinha a régua de cálculo, tinha aquela maquininha Facit, de somar e dividir acho que você conhece. Então você usava um monte de ábacos. Os ábacos eram construções geométricas, escalas normais, logarítmicas, etc, e aí você ia com as réguas lá, entendeu, você tinha uma escala aqui, outra escala aqui, outra escala aqui, uma era o $\sigma$, outra era o $\omega$, outra era o y, sei lá o que. E você pegava um ponto na escala normal, outro fazia pela escala logarítmica. E aí você pegava um ponto, pegava outro ponto (...). Depois que você via este, você punha aqui, ia lá e tal. Enfim, o ábaco era uma coisa que permitia você resolver um cálculo muito mais rápido e com uma carroção deste tamanho. Era uma maneira, isso chamava-se, é uma coisa que você não tem mais hoje: nomografia. Nomografia é o 
cálculo gráfico. Nomo, de cálculo, e grafo, grafia. A nomografia era a especialidade de você criar ábacos. Podiam ser curvos, podiam ser retos, uma série de coisas. Durante muito tempo se usou isso, inclusive na aviação. Até hoje você tem alguns resquícios disso com transparências... (...) Só que com esse treco aqui hoje, aquilo é piada. Aquela minha expressão que eu te mostrei, que é desgraçada se eu fizer o algoritmo e jogar aqui...

(M) Fica pronto na hora.

(E) Qualquer criança de oito anos usa. (...) Mas, enfim, voltando ao caso. O quê que eu tava falando... $\mathrm{Eu}$ comecei a estudar esse troço aqui, e nas hidrelétricas eu aproveitei todos esses recursos técnicos para racionalizar, digamos, a utilização de materiais, para dar o conforto térmico, dar as condições de visibilidade, etc. Não só nas hidrelétricas, mas particularmente, antes até do Convênio Escolar, das escolas. Porquê? Porque a escola é o lugar onde você quer ler. Agora eu vou te explicar o porquê da minha preocupação. Ninguém discute, ninguém nunca discutiu naquela época que a escola era de duas maneiras. Eu vou fazer aqui. Você vai ver se eu estou errado ou se estou certo. É lógico que é, em corte... A escola, o quê que é? Tinha a sala aqui... depois, se tinha duas águas, não sei o quê, não interessa. Você tinha a sala e você tinha o corredor. Então a meninada andava por aqui, etc, e aqui tinha as carteiras, tá certo? E aqui você tinha as janelas. Era isso. Então o quê que acontecia? Essa tal curva tinha aqui. Então quem estava junto tinha até excesso.

(M) Não dava nem pra ler.

(E) Às vezes tinha que ter cortina aqui. E quem estava lá no fundo, tinha pouca luz, é claro. Isso aqui cai, e cai pra danar!

(M) É verdade.

(E) E eu sempre me chateei com esse negócio aqui. Bem, você tem duas maneiras de fazer, por exemplo, você põe isso aqui mais baixo, né. (...) Isso tinha uma grande vantagem. Porque aquilo lá você podia conseguir com um buraco no meio. (...) Eu tinha preocupação com uma série de coisas, insolação, aeração...

(M) O senhor usou esse tipo de solução nas escolas.

(E) Usei, exatamente. Aeração, insolação, iluminação e acústica. Eu achava que particularmente o hóspede desse ambiente, sendo uma criança, mais do que ninguém, ele precisa de conforto térmico, meu Deus! Porque senão fica enchendo o saco também, porque escola é um saco! Para mim pelo menos a escola a vida inteira foi, com raras exceções. Ou estudo nunca convencido, etc, (...) escola moderna, porque a principal coisa é você criar motivação, e aí vale tudo. Se você criar motivação mais da metade do caminho está feito. Agora, na época que eu lidava com isso não tinha esse negócio. Os menininhos e as menininhas tinham que sentar lá e grudar a bunda lá e ficar quatro horas lá e ouvindo o que queriam e o que não queriam. Não é por vontade (...), é claro Você também não pode ter liberdade total, também não dá, entendeu, a questão social. Mas eu acho que a escola, aliás não sou só eu, os pedagogos, tenho o maior respeito por eles, tem problemas sociais, psicológicos, individuais, não é? É uma fase difícil, a criança, as meninas sobretudo, tá com fome, o que é pior ainda, enfim, freqüentemente o professor não está capacitado. Não é que seja ruim. Ele não foi bem instruído, não foi capacitado para aquilo, enfim. Nós temos uma série de coisas. Lentamente estamos superando isso. O Brasil felizmente está evoluindo muito, eu acho.

(M) Melhorou bastante.

(E) Não quero transmitir a sensação de que sou pessimista, hein? Pelo contrário. Eu sou otimista. Agora, eu estou falando de quarenta anos atrás, não é? A situação era muito pior. Então, eu achava que isto aqui, entendeu, o conforto; que não se entenda só por essas questões físicas que estão aqui não, mas as questões físicas também tem o seu valor. De calor, tem um barulhão desgraçado, se eu não enxergo bem, o que eu vou querer também?! É uma droga! Entende? Por isso que todo mundo numa sala de concerto procura ver que não entre som, pra poder aproveitar aquilo, lógico! Senão você não está em condições de poder, no caso aí, resolver esteticamente alguma coisa, mas de qualquer maneira esse conforto é, e mais do que conforto também, do conforto não fazem parte só as questões físicas, trata das questões psicológicas e também a questão que eu acho que é muito importante é a questão da ambientação. A ambientação (...) sobretudo na ..., isso aqui você vai ver depois na minha teoria de arquitetura escolar, vai. Se é que se pode chamar de teoria. Eu acho que a gente tem que buscar a 
função através da arquitetura, a função: enxergar direito, ouvir direito, não morrer de calor. Evidentemente não ter bicho, não ter poeira, é claro. A ambientação a que eu me refiro tem vários aspectos, né? Você tem a questão da ambientação, você pode ver a psicológica. A criança, como é que se pensa isso: tem que pensar em escala. O pé-direito a meu ver não pode ser muito grande, não. Você pode resolver perfeitamente o problema de ventilação e tudo mais sem puxar muito o pé-direto. Porque quando a gente é pequeno, qual é o referencial do espaço? É o espaço que você ocupa. Você já teve a oportunidade voltar para casa depois de muito tempo?

(M) Já!

(E) Você sentiu isso?

(M) Senti! Lá em casa! Nitidamente.

(E) Aquilo que era quando você era jovem, quando você cresceu era ridículo de pequeno. Eu já tive várias vezes essa sensação. Eu pensava que tudo era pequenininho, imagina assim. Quando eu estava no pré-escolar, no primeiro ano, entrava por aquele corredor ... Então, por exemplo os corredores eu abaixava sempre que podia. Até a altura de porta. Aí dizia, pô, mas vai ficar desconfortável para o professor. Que fique! O professor fica pouco tempo lá, e ele sabe compreender isso. Interessa muito mais o conforto das vinte e cinco ou quarenta crianças, claro. Então eu procurava sempre fazer um jogo, aqui, de pé-direito, também. Essa ambientação à criança é pé-direito, então aqui vem uma porção de coisas, janela, porta, etc., forro e tal, e além disso, (...) a criança, a questão psicológica do tratamento também à criança, evidente, tratamento adequado de cores, texturas. Não é por causa disso que nós vamos fazer um carnaval, também. Eu não acho que o carnaval seja necessariamente bom ou não, uma saturação de cores o tempo todo. Mas também, por exemplo, não pode haver arquitetura mais horrenda, eu disse isso (...) que eu tinha oito ou dez anos, e ia para o ginásio, que até hoje digo, e hoje estou compreendendo isso, que é a arquitetura hospitalar. É tudo branco, tudo horrível. Você entrava, naqueles tempos, você entrava no hall. (...) Não tinha como tomar uma refeição naquele tempo, no refeitório lá dentro, lanchonete. Você não podia comer lá, parecia uma morgue. O carinha está sofrendo, as pessoas que estão lá também não estão bem, estão acompanhando. Bom, pelo menos vamos fazer um troço..., que é como fazem os americanos. Os quartos de hospital deles são, procuram ser quartos normais. Não uma pré-morgue, não é. A pré-morgue é boa, porque não parece isso? Aquela história E você tem, se você cortar aqui. Você tem duas curvas aqui. Eu fui o maior destruidor de corredores do mundo. Uma curva que vai fazer isto, e a outra que vai fazer isto. Então você vai ter uma curva (...) isto, praticamente igual, tá certo?

(M) Então isto aqui são duas salas de aula com uma certa insolação.

(E) Olhando para você, é. Uma sala de aula é sul e uma sala de aula é sudeste. E no meio está o corredor.

(M) E aqui é uma planta, não é? Que o senhor está desenhando.

(E) Então, pode continuar, que tem novas salas aqui.

(M) E esse espaço aqui que está aberto...

(E) E então você tem aqui, verde aqui, que é sempre muito bom. Eu fiz muitos estudos de escolas assim. É um troço bonito, gostoso, tem presença de verde, areia, tudo. Outra coisa que você pode fazer é por um em cima do outro. A idéia é a mesma, só que eu tenho que subir com uma escada aqui. Ta com três até, se eu quiser. E aí depende do terreno, de uma série de coisas. Se você tem também um terreno que desce, você pode aproveitar dois, sobe meio, não é? Um terreno que desce assim, sobe, desce aqui. Bota dois andares, não é? Um aqui e outro lá. Mas você tem livre aqui. Livre, livre, então livre, tá livre, tá livre, tá livre. Isso aqui depende de um monte de coisas. Agora o importante é que eu queria fugir, não a sala...

(M) Com janela de um lado.

(E) Com janela de um lado só, exatamente. Não. Pronto. E consegui. Quase todas as coisas, consegui. E em muitos casos, até em escritórios. Você sabe o quê que eu fazia? Cheguei a fazer bastante. Reduzia muito aqui o pé-direito de circulação. Não tinha importância. Eu deixava (...) e fazia, o quê que eu fazia aqui dentro? Fazia aqui ligações pra lá, pequenos ramais e fazia salas aqui, tanto faz, bem maiores, oficinas, ou coisa que o valha. De maneira a poder ter sempre bilateral. Sempre bilateral. Eu 
fui o maior destruidor de corredores do mundo (risos). Corredor aqui sim, claro, mas não corredor entre salas, meu deus do céu! Liberta! Liberta! Não custa nada esse negócio que Deus nos deu, aí.Você ta entendendo o que eu quero dizer aqui?

(M) Eu entendi sim.

(E) Não é nada de misterioso isso aqui. É, coisa... é, até eu vou te explicar (...).

(M) Para mim interessa por causa da necessidade de entender como aqueles projetos eram pensados.

(E) Sim, agora você vendo os meus projetos lá, você imediatamente descobre porquê.

(M) Eu vou perceber isso sim. Agora sim.

(E) Vai perceber porque eu fiz aquele negócio. Parece uma coisa estranha. "Esse sujeito foi procurar um negócio esquisito, complicado aí”. Às vezes não é tão fácil de resolver formalmente, não. E mesmo tecnicamente. Bom, tecnicamente a gente estava lidando com vãos pequenos, (...) muito pequenas, entendeu?

(M) Essas técnicas construtivas eram banais...

(E) Eram comuns, banais. Sim. Banais.

(M) Não tinha novidade.

(E) Não tinha não. Nem podia ter. Nem podia ter porque a gente trabalhava com mão-de-obra de empresas aí, muito... entendeu? Muito terra-terra. Terra-terra. Quer dizer, com se diz aqui. Muito péno-chão, sabe? Se começasse a inventar tecnologias muito diferentes, você não conseguia ninguém! Nem para entrar na concorrência! 
Entrevista

Eduardo Corona, arquiteto

17 de agosto de 2000, em São Paulo - SP

(Mário Caldeira) O Convênio, esse na verdade é o segundo convênio, havia um anterior que produziu muito pouco segundo pesquisas que eu fiz, e nesse segundo Convênio ele começa em 49. O senhor entre no começo quando ele, antes de funcionar ou depois de funcionar?

(Corona) Não, quase no começo, quase no começo. Em 49 foi que eu vim, me formei no Rio. EM 49 vim pra cá e comecei na FAU em maio, que não era nem na Maranhão, era na Poli velha ainda, sabe? A maranhão não tava pronta. O Anhaia Melo que era diretor estava pintando, ajeitando o prédio para ir lá. Eu acho que entrei em 50, acho que entrei em 50, eu não guardo essas datas, é que não me interessa muito, 50, acho que entrei no Convênio Escolar, que era no começo. Que o Hélio Duarte era o chefe e ele me convidou, depois de mim veio o Osvaldo Corrêa Gonçalves, aí começaram a entrar uns três ou quatro arquitetos e só.

(M) Então tinha pouco?

(C) Tinha pouco. Porque a gente dava conta de tudo ...

(M) E vocês faziam todos os desenhos?

(C) Tudo era projetado lá dentro. Tudo. Tudo era projetado lá dentro. A gente fazia o projeto completo.

(M) Até o executivo? Nada passado pra fora?

(C) Nada.

(M) Nem os projetos complementares? Elétrica, hidráulica ...

(C) Ah, não. Isso tudo era contratado engenheiro especializado que vinha fazer, porque lá dentro não tinha isso. Aí contratava lá fora. Mas o projeto arquitetônico era todo feito lá dentro, tudo.

(M) E o senhor trabalhava diretamente com o Hélio Duarte ou, porque tinha o José Amadei que era o...

(C) Não, o Amadei era o engenheiro que era o presidente da Comissão.

(M) Qual era o papel dele?

(C) Presidente. Porque naquele tempo essas comissões e não sei porque cargas d'água a Comissão do Convênio Escolar foi ter essa autonomia, não sei direito, autonomia de fazer projetos e o Hélio Duarte foi um dos responsáveis, claro, de ter isso, mas o Amadei era um engenheiro já veterano na Prefeitura e foi designado como presidente da Comissão e foi concordando com isso. E isso foi importante, porque o Hélio Duarte quis introduzir as idéias do Anísio Teixeira pra o ensino, etc. Então o programa das escolas teve que ser aperfeiçoado, teve que ser um pouco alterado do que era comum, até aquele momento.

(M) Daquilo que se fazia em São Paulo ou daquilo que o Anísio Teixeira ...

(C) Não, não. O Anísio Teixeira, o Hélio Duarte só captou as idéias sobre ensino, pedagogia e tal. E começamos a aplicar tudo isso nos edifícios escolares, e o Hélio Duarte fez um programa naquele momento pra gente fazer os projetos. Então os terrenos vinham da prefeitura, não sei de onde, agora não lembro, vinha para o Convênio Escolar, e diziam - Agora vai abrir uma escola, tal, tal, tal, porque eu sei que tem terreno que eram péssimos, mas eram doação, de interesse político, o deputado arrumava um terreno e vinha pra fazer escola, pronto. Mas acontece que o Hélio Duarte fez um planejamento da cidade, de necessidades de grupos escolares e num dos artigos dele que saiu na Habitat, Acrópole, não me lembro mais, ele estabeleceu um critério em que o aluno, o estudante jovem não devia caminhar mais de 400 metros para chegar na escola. Então num raio de 400 metros tinha uma distribuição de escolas pelo município todo. Então tinha que ser uma para cada lugar pra aluno não ter que tomar ônibus. Esse era um plano bacana, isso não aconteceu, isso nunca aconteceu. Sei lá, 
naquele tempo nós tínhamos 1 milhão de crianças em escola, sei lá, e no fim continuou ano por ano a mesma coisa porque pra fazer os prédios novos levava burocraticamente um certo tempo. Os projetos nossos eram rápidos, mas é concorrência, etc, e as empresas ficaram com aquelas malandragens de encrencar no meio do caminho, enfim, o prédio atrasava! De maneira que quando se enfrentava, enquanto se enfrentava, vamos dizer, $\mathrm{n}$ escolas para diminuir o número de crianças sem escola, já nascia outro tanto. Então não adianta, tinha que fazer tudo numa velocidade tal, ou ao mesmo tempo 40, 50 escolas, isso nunca aconteceu. Enfim, e aí se elaborava os projetos. Cada arquiteto ficava encarregado de um, o Hélio Duarte distribuía para um, para outro, dava o terreno, etc, e a gente projetava com a maior liberdade, com total liberdade fazendo o projeto que a gente achasse melhor dentro daquele programa. Chegou a um ponto, apenas para rememorar certas coisas, sempre me manifestei desde o começo contra o maldito galpão de recreação, que se chamava galpão de recreação. Então esse tal de galpão de recreação, até o nome para mim era pejorativo, eu não gostava desse troço, eu achava que devia ter "recreio coberto". E faltava auditório em todas as escolas, porque não estava no programa e os pedagogos da prefeitura não pediam, então pronto, os projetos para mim estavam incompletos, sempre incompletos e fica provado hoje que é mais ou menos isso aí. Uma escola dessas não podia ficar ociosa, nem à noite nem fim-de-semana. Então devia ter cinema, palestras, pra comunidade onde ela estava. Claro! Pra não ficar um prédio fechado. Porque pra criancinha não tem curso noturno. E nunca aconteceu porque não tinha... aqueles galpões no inverno de São Paulo não serviam para nada.

(M) Eram como esse aqui?

(C) É, esse aqui, é.

(M) É, está escrito aqui, galpão de recreação.

(C) É, pois é, era o nome que se dava.

(M) E era tudo aberto assim?

(C) Era tudo aberto. Era só pra... na ponta tinha, de um modo geral a cozinha.

(M) Esse projeto aqui, Vila Ipojuca.

(C) Está aqui, olha. De quem é esse projeto?

(M) Arquiteto Osvaldo Gonçalves.

(C) Do Osvaldo, que entrou logo depois de mim. Olha aqui, o galpão era isso. Tinha todos os sanitários aqui e a copa e cozinha ali. Então na hora do recreio, que claro, nessa escola era tudo organizado. Batia o sinal, tinha 10, 15 minutos de recreio. Então todos desciam, a professora controlava, vinham aqui [aponta para o galpão] brincar, tomar sopa escolar ou copo de leite e usar os sanitários, só, e brincar aqui embaixo, pronto acabou. Era esse o programa.

(M) Havia algum sistema construtivo pré-estabelecido? Vocês é que determinavam tudo?

(C) O que a gente fazia era o sistema mais comum, porque queriam que tudo ficasse muito barato, o que também me deu motivos, em 53, de eu pedir demissão. Mas também já estava no fim lá. Pedi demissão, porque eu liderei esses movimentinhos ali com os outros arquitetos, quando a gente exigia materiais de primeira para as escolas. Porque não nos baseávamos em que uma escola deve ser feita para servir a muitas gerações, e não uma porque tudo que se fez naquela época está podre, praticamente. Alguns conseguiram conservar, manter, fazer manutenção. Alguns... mas muitos, estão todos anarquizados, tudo quebrado, é o diabo! Porque é tudo ordinário. Então, uma ocasião que eu propus que as portas das salas de aula fossem pintadas, coloridas, pronto, os engenheiros caíram em cima.

(M) Os engenheiros da prefeitura?

(C) Do Convênio Escolar! Tinha a Comissão de Obras, que era de engenheiros ali dentro. Que fiscalizavam e dirigiam as obras, com a construtora que vencesse a concorrência. E não permitiam arquiteto ir lá.

(M) Ah, não?

(C) Não, não podíamos dar palpite. 
(M) Na obra?

(C) $\mathrm{Na}$ obra, porque se a gente fosse ia dar prejuízo para a construtora, porque "está errado, modifica aqui, não é assim não", pronto. Portanto o arquiteto só atrapalhava. Então protestaram. "Não porta de escola pintada não. Criança mete o canivete, dá pontapé, tem que ser de madeira envernizada mesmo e está acabado". Então, todo o processo construtivo que foi se adotando foi o mais normal da época, para a obra ser barata. Para a prefeitura, diziam os engenheiros-chefes, os da Secretaria de Obras e etc., que economizando em um dava para fazer dois, com determinada verba, então pronto. Aí, os acabamentos eram todos precários. Fachada pintada de látex, nem tinha látex naquela época, sei lá o que tinha, não me lembro mais, era uma pré-pintura ordinária pra ficar lá, e tal, acabou. Nós conseguimos, não sei também porque cargas d'água, fazer esses arcos de concreto pré-moldado, que eles nunca faziam.

(M) Pré-moldado?

(C) Pré-moldado.

(M) Isso era feito em outro local, ficava pronto...

(C) A construtora comprava os arcos prontos de empresas que faziam. Então vinha o pré-moldado e botava na obra, ah, bom, isso é uma inovação que eles não costumavam fazer, mas nós acabamos... o Hélio Duarte com uma certa força entre os chefões lá conseguiu aprovar.

(M) Que outras inovações vocês conseguiram implantar nesses projetos?

(C) Nas plantas. Nos projetos. Aí é que tem. Então as plantas das nossas escolas, começaram assim dentro do nosso critério, racionais. Porque nós começamos a adotar o critério, que nunca se adotou, até aquele momento, de orientação da sala de aula. Então pra São Paulo, as salas de aula tinham que ser norte-nordeste. Porque a criança tinha que ter o benefício do sol da manhã, dentro da sala de aula e jamais botamos uma sala de aula para oeste, por exemplo, nunca. A não ser, uma vez ou outra, que por ordens superiores mandaram aproveitar um projeto feito pra botar noutro terreno e aí botaram de qualquer jeito.

(M) Isso acontecia também?

(C) Acontecia. Aconteceu anos depois, claro. Quando começaram a fazer mais demagogia sobre isso. E a galeria das salas de aula, com elas sempre orientadas para a melhor direção, sempre, olha aqui [aponta para o projeto], nordeste. Sempre, sempre a melhor orientação para as salas de aula. Para ter os benefícios do sol da manhã...

(M) O projeto é da Vila Monumento.

(C) Então começamos a introduzir as inovações, e as inovações que eram preconizadas pela União Internacional de Arquitetos, Comissão de Escolas.

(M) Havia uma Comissão de Escolas na UIA?

(C) Havia. Eu fui a uma reunião uma vez, mas fui em 60. Fui na década de 60. Esse aqui é o meu parque infantil (aponta para o projeto). Então, começamos a abrir janela para a sala de aula. Porque a pedagogia moderna internacional preconizava que uma criança até certa idade, precisa ter prolongamento visual. Não pode ficar, não agüenta, por exemplo, numa sala toda emparedada e prestar atenção numa professora, não dá. Não dá. Pedagogicamente, não dá. Então, nós começamos a abrir vastas janelas, botar vidro de ponta a ponta. Coisa que ninguém fazia, sempre era aquela janelinha estreita, aquela porcaria. E janela estreita, nós provamos, que janela estreita fica com um pedaço de parede que dá sombra na mesa escolar. Dá sombra. Então a criança começa a fazer esforço visual. E ninguém ligava naquela época, então essa funcionalidade...

(M) Esse esforço é por causa do contraste entre sombra e luz?

(C) Claro, claro. Então o que se chamava de funcionalidade na arquitetura, nós fomos adotando. Olha, aqui o meu galpão (aponta para o projeto), banheiros e cozinha. Banheiros aqui, meninos e meninas

(M) E os arcos, o galpão dos arcos...

(C) Tem os arcos aí. Então, isso aí eles aceitavam, então isso aí nos aproveitamos para fazer essas inovações, etc e tal. Aí, parque infantil, o programa tinha um teatrinho... 
(M) Essa diferença entre as escolas que vocês faziam e o parque infantil... Qual era a diferença principal?

(C) O parque infantil tinha muitas coisas... E só foram feitos acho que três ou quatro, não me lembro mais. Três ou quatro. Eu peguei esse aqui nem me lembro porque e tal. Então tem um programa mais ambicioso e segundo me disse o Ricardo Carranza, que está fazendo o Doutorado na FAU com o Lúcio Gomes Machado, ele está fazendo... a tese dele é sobre a minha obra. Sobre os meus projetos, que eu nem queria no começo, mas o Lúcio Machado insistiu e eu acabei encontrando aqui, eu digo não tenho mais nada, eu fechei o escritório, não tenho mais nada, e eu encontrei aqui montes de, está tudo acumulado ali no cantinho, de desenhos e croquis e anteprojeto e tal. E o Carranza fez uma pesquisa maior e foi aqui visitar isso aqui, e diz que está agora conservado, não sei o que, que está direitinho, e tal, estavam pintando. Então está bom.

(M) Então eu achei outro aqui, o grupo escolar Erasmo Braga.

(C) Esse é meu.

(M) Lá no Tatuapé. Agora esse aqui tem uma situação diferente, o galpão está embaixo do prédio...

(C) Claro. Aí é uma outra inovação que nós conseguimos convencer os engenheiros que quando o prédio tinha dois pavimentos, e pelo terreno, que era pequeno, ou pelo programa que era vasto, a gente podia aproveitar a estrutura embaixo. É um troço normal. No fundo é um galpão aberto, do mesmo jeito. Porque no inverno, aí que vai fazer aí, cineminha? Ninguém senta. Fazer uma festa de formatura no inverno, não faz, porque ninguém agüenta, está aberto. Não permitiam fazer auditório, que a gente lutava por isso. Então aceitaram porque a estrutura de concreto armado passou a ser reconhecida como necessária em prédios que não fossem térreos! Fosse com dois pavimentos, etc, então conseguimos fazer coisas diferentes assim, e foi dando certo, não é? Foram aceitos esses projetos dos arquitetos.

(M) E eles passavam por uma aprovação dos engenheiros?

(C) Não, não.

(M) Era para construir, já?

(C) Era. De modo que o Hélio Duarte que era o chefe da parte de arquitetura, e tal, que dava inteira liberdade pra gente, acompanhava tudo, ele fazia também os dele. E aí, pronto, está resolvido, acabou. E o José Amadei que era o presidente, assinava embaixo. Não botava dificuldades. Porque era um homem inteligente, e tal, então viu que a arquitetura precisava evoluir. Modificar. Então os projetos até antes disso eram tipo José Maria da Silva Neves. Os projetos do Neves são, vamos dizer, não funcionais do ponto de vista que a gente adotava aqui. A arquitetura dele era boa, limpa porque era já pré-modernista e tal, ele já fazia uns projetos bonitos e tal, mas as plantas, não interessa, de qualquer jeito. Então um corredor com sala pra cá e sala pra cá nós nunca fizemos.

(M) É mesmo! Não tem!

(C) Nunca, nunca, nunca.

(M) Não tem. Só tem corredor de um lado.

(C) Ah, sempre. Não tem sala de aula com dois lados. É, não temos não. Eram todos com a orientação melhor no terreno para... Às vezes tem terreno complicado, e tal, então a gente tinha que fazer...

(M) Escola Nova Branca, do [arquiteto] Tibau. Deixa eu ver se tem outro. Tem vários aqui. Inclusive saiu agora aquele livro do Mindlin, e tem um projeto seu lá.

(C) Ah, que é um ginásio, da Penha.

(M) Isso, ginásio da Penha.

(C) Foi, não sei, um dos últimos que eu fiz, não me lembro mais, e tal.

(M) Esse aqui também é...

(C) Ah, esse é uma biblioteca infantil, biblioteca em Santo Amaro, não é isso?

(M) Isso, em Santo Amaro. 
(C) É, isso é dentro de um parque ou coisa parecida que já tinha... Isso é uma biblioteca pequenininha, que acabaram construindo lá, e nem sei se isso hoje está lá. Sei nada.

(M) Isso eu vou pesquisar também.

(C) Se deixaram, se demoliram...

(M) Depois que eu comecei a pesquisa é que eu fui ver que eu estudei em um dos colégios do Convênio Escolar. Esse aqui, do Hélio Duarte, o Brasílio Machado. Estudei dois anos lá, mas eu só fui descobrir isso quando eu abri um dos livros que eu estava usando, e olhei, está lá. E está razoavelmente... teve uma certa ampliação, algumas coisas foram modificadas, mas a idéia geral está lá. Sempre foi muito agradável, porque é uma planta em "U”, então o pátio ficava muito...

(C) Ficava no meio...

(M) Mas o galpão era, até hoje era, pelo menos até quando eu estudei era aberto. Não dava pra fazer nada lá. Um frio, um vento.

(C) Nada, não serve para nada. Só no verão, para brincar na sombra. Só.

(M) Como é que o senhor foi para lá no Convênio?

(C) Acontece o seguinte, que eu lembre mais ou menos: eu vim para São Paulo, em 49, me formei em 46, fiquei no Rio com, vários anos trabalhando com o Oscar Niemeyer e tal, e tinha aberto um escritório desde 42, 43, com mais quatro colegas de turma, e pela primeira vez abrimos um escritório de desenho para os arquitetos. Então nós desenhamos para o Oscar Niemeyer, para o Reidy, para o Jorge Moreira, para todos os arquitetos bacanas do Rio desenhamos, nós desenhamos. Enquanto estudantes! Depois que me formei fiquei ainda um tempo trabalhando, fiz alguma coisa em colaboração com o Oscar Niemeyer e tal, depois fui para um outro escritório, do arquiteto Saldanha. Firmino Saldanha, que tinha uma empresa construtora também, e pegou alguns projetos e me dava para eu projetar. Ele assinava e eu projetava. Que eu queria desenvolver. Bom, e conheci no Rio, em 49, o Abelardo de Souza, que teve lá. Antes, eu tinha conhecido antes o Artigas, que foi para os Estados Unidos, e passou lá e dormiu no IAB. Uma noite. Dormiu no IAB, porque não tinha onde ficar ou não queria gastar, alguma coisa assim. E foi para os Estados Unidos, ganhou uma bolsa, não me lembro mais. E pegou lá. Então eu fiquei conhecendo, porque eu estava sempre...bom, no último ano, em 46, eu já era da diretoria do IAB, como aluno ainda. O negócio, eu fiquei lá porque eu tava sempre metido nisso. Conheci então o Abelardo de Souza. O Abelardo foi pra lá pra conseguir, pra procurar um arquiteto que viesse pra São Paulo, para ser assistente do Anhaia Melo, que é o que dava na FAU Teoria da Arquitetura, e era o diretor da FAU. Aí, eu estava colaborando muito com o Oscar, e o Oscar, naquele momento, estava quase sem projetos. Poucos. Só tinha o prédio do Cruzeiro, da revista O Cruzeiro, que o Assis Chateaubriand tinha dado para ele. Então o Oscar, naquele tom de brincadeira, que a gente... "Pombas, olha aqui, o negócio aqui está ruim. Quer ir pra São Paulo?". Eu disse "Está bom, eu vou". Porque eu gostava de lecionar. Eu tinha uma certa propensão, um certo gosto para fazer isso. Então eu vim para São Paulo. Conversei com o Abelardo de Souza e acabou. Apresentaram-me na FAU para o Anhaia Melo, e me nomeou como assistente e tal. E eu ia muito... vou contar para você um fato para você assim, um pouco pitoresco, e tal, mas que é realidade, eu contei até para o Carranza que tava aí e para outros que vieram conversar comigo. No Rio de Janeiro, desde os tempos de estudante, a gente convivia com os arquitetos diariamente, todos. E mais, como parentes, e mais, no Café Vermelhinho que era... A arquitetura era dentro do Museu Nacional de Belas Artes, aquele prédio do lado, na avenida Rio Branco, pela Araújo Porto Alegre você entrava pra arquitetura, pintura, escultura e gravura. Era tudo isso. Então nesse café Vermelhinho, que a gente tava, quase do lado da escola, eu particularmente convivi com Portinari, Vinícius de Moraes, Carlos Drummond de Andrade e essa turma toda. E os arquitetos todos, os mais badalados do Rio da arquitetura moderna brasileira. Então eu já tinha essa grande propensão. Vim para São Paulo e como trabalhei de 46 a 49 com Oscar Niemeyer e outros, colaborando com outros, estávamos todos os dias juntos e invadindo o escritório um do outro, praticamente. Entrando... "Pára aí, vamos, pára de trabalhar, vamos beber chope, vai, vambora". E se entrava, e se olhava nas pranchetas tudo que acontecia: "Pô, o quê que é isso aí?" e tal. Aí chegava o Oscar e "Pô, mas isso aí está uma merda, [risos] peraí, muda um pouco e tal". Quer dizer, havia essa convivência, essa liberdade. Quando eu vim para São Paulo eu fui ao escritório do Artigas, que era ali na esquina da São João com... sei lá. Ele me recebeu na sala de espera. Não me deixou entrar. No atelier não me deixou entrar. Nunca mais fui 
para o escritório dele. Fiquei muitos anos... Aí fui descobrindo que os arquitetos de São Paulo tinham muitos ciúmes um do outro. Em 49 eu fui para a diretoria do IAB, fui primeiro diretor de sede do IAB, ali na General Jardim? Não, como é que é?

(M) Em frente a Praça da República, no sótão, lá do edifício Estér?

(C) Não, no Clube dos Artistas foi o primeiro. Depois do Clube dos Artistas passou para o edifício do IAB na...

(M) Na Bento Freitas.

(C) Na Bento Freitas! Bom, aí eu já fui lá. Então ali começamos a, tinha um restaurante, começamos a confraternizar todos. Mas no escritório, ninguém ia do outro. De jeito nenhum. E ninguém contava o que estava fazendo para o outro. Com medo do outro se intrometer. E no Rio de Janeiro era tudo diferente. Mas enfim, isso é um parêntese que eu estou contando. Então comecei a... como o Abelardo de Souza ficou meu amigo eu comecei a visitar arquitetos nos seus escritórios, e eu forçava a barra. Eu ia, e ficava lá, forçando e conversando. Então, indo ao escritório do Abelardo, o Hélio Duarte era sócio dele. Tinham escritório juntos. Naquele tempo não tinha sociedade. Não era empresa, não existia empresa. Trabalhávamos juntos, eventualmente, em um projeto ou outro, fazia sozinho outro. Então, pronto, fiquei amigo do Hélio Duarte também. Aí, logo em seguida ele me convidou para ir para o Convênio Escolar, que eu não lembro mais. Então, pronto, aceitei logo. Porque é lógico, eu tinha só as aulas da FAU e o meu escritório, que abri logo meu escritório, mas no meu escritório também, no comecinho era precário, uma coisinha ou outra de cada vez, e tal. Então pronto, por isso é que eu fui para o Convênio Escolar, porque o Hélio me convidou.

(M) [No Convênio Escolar] vocês eram considerados como engenheiros então?

(C) No Convênio Escolar nós éramos operários de obra. Tinha um outro nome. Só. Não tinha o nome de arquiteto porque não existia essa classificação. Só anos depois que o Ministério, o Governo brasileiro instituiu a profissão do arquiteto no serviço público. Então o general Dutra, se não me engano, quando foi presidente, sei lá. Não me lembro mais. Aí criaram a profissão de arquiteto que não tinha. Então só tinha emprego no serviço público alguém como o José Maria da Silva Neves que era engenheiro-arquiteto. Aí entrava na classificação de engenheiro, pronto, aí é diferente. O Artigas foi, mas o Artigas nunca quis ir para o serviço público. Era engenheiro arquiteto também, da Poli, e assim foi, quer dizer, a profissão não tinha amparo em lugar nenhum. Então arquiteto empregado não tinha. As grandes empresas também não empregavam arquitetos. Não queriam arquitetos. Não encomendavam projetos para arquitetos. Década de 40 para diante, não encomendavam nada. Uma ou outra exceção pode ter havido de uma empresa. $\mathrm{O}$ arquiteto não era nem sócio, não era nem dono, não era nada. E os projetos que a gente fazia, toda a década de 50, eu acho, toda, eu pegava projetos até do Banespa [Banco do Estado de São Paulo], que eu fiz algumas agências e tal, fiz amizade com o Carvalho que era o engenheiro chefe da engenharia, não me lembro mais. Eu fazia para o Banespa, me pedia um projeto, eu fazia uma carta... "Prezados senhores", e tal, "sentindo prazer em colaborar, executar um projeto", assim e assim, "pela tabela do Instituto de Arquitetos daria tanto pelo projeto, mas no caso de Vossas Senhorias eu faço por tanto", abaixava um pouco, e assinava embaixo. O Departamento de Engenharia lá carimbava "de acordo", pronto, contrato feito.

(M) Era só isso?

(C) Só. Não tinha imposto de renda, recibo. Não tinha nada, nada, nada. O processo de trabalho era só esse. Quando começou a coisa a modificar, eu no IAB, eu e o Artigas, o Ícaro de Castro Melo, o Zenon Lotufo, começamos a protestar contra a implicação do arquiteto como empresa, para pagar imposto, Secretaria da Fazenda, selo de não sei o quê. Pronto aí começou a atrapalhar. Mas aí começou a levar arquitetos a fazerem empresas.

(M) Isso a partir de quando mais ou menos?

(C) Cinqüenta, sei lá, 57, 56, não me lembro direito, e o Croce, Aflalo e Gasperini foram os primeiros a fazer uma empresa. Registrar bonitinho e tal. E nós criticamos no IAB: "Que sacanas!", "Como é que é? Arquiteto é profissional liberal! Não tem que fazer essa porcaria!”. E no fundo eles estavam certos. Hoje quem não fizer empresa está roubado.

(M) Uma coisa que eu percebi estudando a literatura sobre o período, artigos, revistas como essa aqui, a Habitat, eu vi que muitos arquitetos do Convênio projetaram também para o SENAC. 
(C) Era o Hélio Duarte e o Tibau. O Hélio Duarte tinha muita amizade, se não me engano com o Simonsen, que era o presidente do SENAC na época. E ele dava projetos para o Hélio.

(M) Mesmo ele estando dentro do Convênio?

(C) Não tinha problema. Não tinha exclusividade nem nada. Eles eram operários de obra. Fazendo projeto e ganhando um salário miserável. E eu tinha meu escritório a fazer, meus projetos do mesmo jeito. Ao mesmo tempo eu tinha o meu escritório. Eu não lembro de nem como é que eu dividia meu horário, eu não sei... Aula era uma vez por semana, mas eu não me lembro como é que eu contornava a situação, porque sempre mantive meu escritório, sempre tive servicinho. Então fazia as duas coisas. A gente tinha liberdade, porque era classificado com operário de obra. Aí o Hélio fez alguns projetos com o Tibau, ficaram muito amigos, e o Hélio começou a dar projetos para o Tibau, junto com ele ia fazer para o SENAC, depois entrou no rolo o Mange, Ernesto Carvalho Mange que é engenheiro, não é arquiteto.

(M) Não é arquiteto?

(C) Não, ele não é arquiteto. Mas é um excelente arquiteto. É um excelente arquiteto.

(M) O Mange é daqui de São Paulo ou é do Rio?

(C) Não, eu acho que é de São Paulo.

(M) Isso me chamou também a atenção. O Hélio Duarte é do Rio, o senhor é do Rio. O Tibau não tenho certeza.

(C) O Tibau formou no Rio.

(M) O Corrêa Gonçalves...

(C) Não, o Osvaldo é de São Paulo. O Osvaldo é da Poli.

(M) Havia outros arquitetos aqui em São Paulo. Por que eles vieram?

(C) Havia, mas é por causa dos grupos de amizade. Só.

(M) Veio o Hélio e veio trazendo...

(C) E o grupo de amizade está todo dia junto. No IAB se encontrar... tirando de fora os arquitetos que tinham já o seu escritório, tipo o Artigas ou outro, que já tinham o seu desenvolvimento profissional, não interessava aceitar empreguinhos aqui ou ali. Mas no fundo era isso aí.

(M) No caminho, é uma primeira leitura que eu faço, no caminho seguido, por exemplo, pelo Osvaldo Bratke, pelo Artigas na arquitetura deles é um pouco diferente, bastante diferente da que vocês faziam no Convênio. Havia uma certa distância de, no mínimo de desenho, de soluções adotadas?

(C) No fim, não sei , sabe? Porque o Bratke já era um arquiteto de primeira categoria aqui em São Paulo, o Rino Levi, o Bratke, o Artigas e tal. Mas eles não tinham enfrentado esse tema.

(M) É verdade.

(C) É, nunca. Então, nós tivemos ali de inovar o programa e as soluções arquitetônicas. É que foi, fomos dando uma característica àquilo que é a que está publicada desde aquela época, mas eles tinham outros temas, outros projetos diferentes.

(M) A impressão que dá olhando, não uma só escola mas o conjunto, é de que tem uma certa marca, vamos dizer assim, característica e era isso que eu queria saber. Essas soluções de projeto, por exemplo, são muito comuns as plantas longitudinais, mais do que volumes, blocos fechados.

(C) Claro, por causa da orientação.

(M) Isso é mais pela orientação?

(C) Ah, mais pela fila da sala de aula. Porque a gente tinha grupo escolar, eu acho que o menor era 6 salas, 8 salas, 12 salas. Ou embaixo, ou em cima, acabou. Ficava sempre uma coisa comprida. Por isso que tinha terrenos que a gente rejeitava por que não dava pra fazer, mas isso eu não me lembro mais. "Aí não dá" e tal, porque queriam doar uns terrenos que eram uma biboca lá que não servia para nada. Mas acontece que essa característica, eu quero ressaltar outra vez, da convivência dos arquitetos cariocas no Rio de Janeiro, o Rio tinha muito que não era carioca, mas arquitetos do Rio de Janeiro, do 
grupo grande de arquitetos modernistas brasileiros, era o convívio, convívio de irmão, todo dia, todo dia praticamente, todo dia, todo dia ia para a farra junto, ou então ia para beber, ia para conversar, era no café, aquele que se encontrava, e tal. Então houve uma unidade arquitetônica na arquitetura carioca. Houve uma unidade. Porque cada um conversava e via o que o outro estava fazendo, e ia legitimamente chupando a idéia, não tem problema nenhum, a palavra não é pejorativa. É adotar aquele, "pô, que bacana! Vou fazer também".

(M) Se a solução é melhor, porque não adotá-la.

(C) É, "vou fazer também". E os arquitetos de São Paulo, depois que eu vim, isso é uma crítica que faço eu, até hoje eu não li ninguém falar nisso: como tinham aquela ciumeira, ninguém se visitava, ninguém ia olhar o projeto do outro a arquitetura moderna paulista é heterogênea, não tem aquela corporificação que tem a dos arquitetos do Rio. Ficou diferente, porque cada um projetava de um jeito. Claro que depois que começaram a publicar os projetos de A, B ou C, daqui, dali, Rino Levi, Bratke e tal, aí começou a influenciar pelo fato de ter veículo de publicação, porque não tinha então nada, não tinha revista, não tinha coisa nenhuma. Aí, pronto, aí começou, o pessoal podendo estudar os projetos e tal.

(M) Essas revistas são todas, essas publicações também são todas depois de 50, não é? As principais, Acrópole e tal...

(C) Tinha uma revista da Poli, tinha uma revista da Prefeitura, que aí de vez em quando publicava um projeto de A, B ou C, e tal. Mas era pouco. Muito pouco.

(M) E nesses projetos das escolas lá do Convênio, uma coisa que é interessante: apesar dos projetos serem diferentes, eles realmente têm essa unidade. Agora uma coisa que chama a atenção é que alguns dos elementos desses projetos aparecem algumas vezes. Por exemplo, o galpão...

(C) É claro.

(M) Ou uma disposição do palco dentro do galpão. Isso também...

(C) Tudo. Sabe porque, porque a gente projetava em um grande salão. Osvaldo Gonçalves aqui, o Tibau ali, outro ali, a gente estava toda hora passando e conversando. Um vendo o projeto do outro. É, um vendo o projeto do outro. E discutindo e conversando. E acabou. Tínhamos aquela, o amparo do Hélio Duarte, para inovar os programas e ele tinha feito um ou dois projetos antes. Ele já deu, abriu o horizonte para a gente. Mas tudo era feito assim, tudo junto num salão só.

(M) Isso ajudava também, o fato de ter já um certo direcionamento, ajudava também no tempo do projeto, quer dizer, o tempo para fazer um projeto e deixar ele chegar até o executivo?

(C) Nós tínhamos muitos desenhistas empregados da prefeitura que trabalhavam com a gente, então desenvolviam tudo. Então, os anteprojetos que a gente fazia, eventualmente, um ou outro, eram desenhados pela gente mesmo, a mão livre, aqueles troços, como eu tenho alguns aí e acabou. Depois passava logo para desenvolver e está acabado. Aí tinha um monte de desenhistas, quatro, cinco ou seis, não me lembro mais.

(M) Isso é algo também que estava me chamando a atenção. Em alguns momentos o galpão, ele está fora, está deslocado da massa de salas de aula, outras vezes ele está incorporado.

(C) Com passagem coberta. Não sei, alguns têm.

(M) Por exemplo, esse aqui está...

(C) Bom, esse aí servia de galpão, não? Acho que sim. O Tibau já fez dentro do... Porque foi dos últimos projetos.

(M) Quer dizer, no começo...

(C) Era tudo térreo. Então vinham os critérios. Primeiro, se as salas de aula tinham uma boa orientação, de um modo geral, como o galpão era coberto a gente botava o galpão do outro lado que é para não perturbar a algazarra.

(M) Por causa da garotada.

(C) É, mas com isso quase nunca acontecia, porque a garotada tinha horário certo para descer para o galpão. Tudo controlado pelas professoras. Desciam em fila. Então acabou. Depois que ia todo mundo 
para a aula, ficava tudo em silêncio. Mas de vez em quando tinha um grupo que ficava brincando, jogando bola lá fora, e tal. Então, ficava do outro lado.

(M) Fico impressionado é com a quantidade, com a variedade de soluções. Por exemplo, essa aqui, que é do Tibau.

(C) É do Tibau.

(M) Essa disposição aqui, de salas de aula, intercaladas por pátios, isso aqui eu não tinha visto ainda.

(C) Pois é, isso foi uma coisa nova que ele fez e que as salas abriam todas para o norte. Isso aqui, eu não sei, não me lembro. Que número está aqui? Dez?

(M) Dois. Sala pré-primário. É o pré-primário aqui.

(C) Não, a sala, mas o que está no meio...

(M) Um. Aula ao ar livre.

(C) Ah, pois então é isso aí. Ah, porque ele tinha o pré-primário aqui. Então pronto, as professoras às vezes, em dia bonito, dava aula lá fora. Era uma inovação que só o Convênio Escolar fez, porque não existia, mas existia na Europa, existia nos Estados Unidos, na França, na Inglaterra. A gente via todos aqueles livros, os prédios bacanas para burro, plantas bacaníssimas, tudo de vidro até o chão. Nós nunca conseguimos fazer vir até o chão aqui, que o engenheiro não deixava de jeito nenhum. Tinha que parar a uns 80, 90 de parapeito e tal. Mas conseguimos janela ampla para não ter sombra dentro. E a luz da esquerda, os bancos colocados, a professor lá, luz da esquerda aqui para a criança, para ter a racionalidade de uso e a iluminação que a gente exigia dos engenheiros de eletricidade para ter boa iluminação no quadro negro, e boa quantidade de lux na superfície de trabalho, para a criança não ter esforço visual. E isso ia contribuindo. Ah, mas esse é o pré-primário que a criançada brinca lá fora. Tem aula lá fora.

(M) No começo, então, o tipo de projeto, por exemplo, esse aqui eu conheci bem, porque foi nesse aqui que eu estudei, o do Brasílio Machado, do Hélio Duarte. Esse aqui também, o galpão já era embaixo.

(C) Já era embaixo.

(M) Na verdade, esses projetos que o galpão já fazia parte...

(C) Porque o terreno exigia. Não dava. Tinha que fazer outro andar em cima. Então, aproveita.

(M) Então tudo para o aproveitamento do terreno.

(C) É. E o terreno é ou apertado ou acidentado, uma das duas.

(M) Esse aí era apertado.

(C) Então tinha que fazer assim. Não dava, não sobrava área para fazer um galpão fora. E aí é simpático, só que também é ruim, por causa do vento, dia de chuva, no inverno não serve para nada.

(M) Era isso mesmo. Esse aqui por exemplo, esse aqui é do Osvaldo.

(C) Aí tem os arcos, mas ele ligou com as salas de aula. Bom, ele ligou por ligar, porque encostava no prédio.

(M) Mas na verdade ainda era a proposta do galpão isolado.

(C) É, isolado.

(M) Então, no começo ele era mais isolado e depois, ou isso não tinha, não teve uma época em que começou a ser implantado?

(C) Não. Desde que eu comecei já era. Porque o Hélio Duarte já tinha feito um programa mais evoluído de escola.

(M) A minha idéia, inclusive é a seguinte, é de depois conseguir fazer alguns desenhos melhores dessas plantas, e começar a analisar os projetos, mostrar as diferenças, os avanços, as conquistas, acho que explicando assim fica mais fácil de entender, tem algumas coisas que são super importantes. Como por exemplo, você estava falando aqui dos arcos. E isso aqui era telha de cimento-amianto? 
(C) Telha de cimento-amianto. Da Eternit, porque era a primeira que tinha aqui. Tudo Eternit. Alguns casos de alumínio, mas fazia muito barulho em dia de chuva. Então o que dominava era o cimentoamianto, porque não repercute muito o barulho, o que era contra nossa idéia. Nós queríamos fazer era de casca de concreto mesmo, mas aí não aceitavam. Aí, as idéias não queriam aceitar de jeito nenhum. Porque encarecia a obra, não sei o quê. Aqui [na Vila Anastácio] teve que ser orientada para lá por causa da orientação das salas de aula. Então, como está distante também e era só recreio, mas tinha uma parte coberta aqui para ir lá, sem tomar chuva. Saía por aqui, e ia embora para lá, ou vinha para o lado de cá.

(M) Isso que eu vejo em todos eles, o edifício, como eles são vários volumes que vão se compondo, sempre ficam essas áreas razoáveis, bastante grandes até, áreas livres. Isso também era um resultado só da implantação do prédio ou era o objetivo deixar livre?

(C) Primeiro que os projetos eram resolvidos de uma forma que se achasse racional, não é, funcional pelo menos. Quando o terreno era meio grande., a gente fazia o quê? Nada? Fazia paisagismo. Fazia parque, fazia isso, fazia aquilo, mas nunca foi feito nada. A prefeitura naquela época não fazia nada, coisa nenhuma. Então, plantava lá umas árvores só e olhe lá. Então, conforme o terreno às vezes a gente tinha mais inspiração para deixar o prédio soltinho no terreno. [apontando para a revista] Esse acho que nem foi construído, tenho a impressão. Não, é, acho que foi sim. Sei lá. 
Entrevista

Celso Lamparelli, arquiteto

24 de abril de 2001, em São Paulo - SP

(Mário Caldeira) O que foi o Plano de Ação feito durante o governo Carvalho Pinto?

(Celso Lamparelli) Quando mudou o governo no estado de São Paulo, o Carvalho Pinto foi eleito, em 1959, e imediatamente a equipe coordenadora do governo dele montou uma equipe complexa para fazer o Plano de Ação do governo do Estado. E eu fui chamado, convocado para trabalhar com eles no Plano de Ação. E no Plano de Ação eu acabei, por interesse meu, e por experiência anterior, e por ser filho de professores primários, fiquei responsável por todo o setor de educação no Plano de Ação do Carvalho Pinto. Então em 59 eu trabalhava no Palácio do governo da equipe, não da equipe macro, da equipe importante. O Plano de Ação tinha uma equipe de notáveis, em que estava o Fernando Henrique, Delfim Neto, esse pessoal todo lá, e a equipe de batente que era a equipe dirigida pelo Plínio de Arruda Sampaio, essas coisas, esses detalhes não tem nada escrito que eu conheça. Mas nesse trabalho do Plano de Ação eu fiquei encarregado de coordenar toda a pesquisa, todo o trabalho da educação, não só da educação primária como da educação superior. Então eu participei intensamente de toda a programação e de toda a coordenação, do controle, distribuição de verba, etc., de todo o setor da educação cuja tradição de planejamento era zero, era baixíssima. Então uma das coisas que eu me lembro, isso deve interessar a você: eu fui procurar o professor Carlos Pasquale, que era o Secretário da Educação da época. O professor Carlos Pasquale...

(M) Seu trabalho não era vinculado então à Secretaria de Educação?

(C) Não, eu era do Palácio do Governo. Eu era coordenador, assessor, de todo o Plano de Ação do setor educacional, certo? Isso em 59. 1959. Fez-se o Plano de Ação. Ficou pronto. E a peripécia para fazer o plano era convencer os técnicos da secretaria que precisava fazer o levantamento preciso, qual a situação da educação daquela época. Especialmente, como o Plano tinha um setor de investimentos, como é que estava a rede escolar. Então a preocupação era o levantamento da rede escolar. Eu já sabia que a situação era péssima, especialmente na capital, porque eu tinha participado, há uns dois anos antes, em uma pesquisa em que levantava a situação da educação também. Então, a pesquisa do padre Lebret, ou da SAGMACS, fazia uma verificação do nível de atendimento da educação, das condições dos prédios, etc., e eu já sabia que a condição era precaríssima. Mas eu encontrei uma inexistência de dados. A Secretaria tinha um papel ofício, um papel daquele de fazer prova, escrito com letra gótica. Cada prédio tinha uma folha destas em uma pasta AZ. Informações completamente desatualizadas, etc. Então em uma conversa com o secretário ficou estabelecido que com relação aos prédios escolares, que era orientação não só dele, mas da participação que ele teve no congresso de $58 \mathrm{em}$ Washington, em que a Aliança do Progresso dizia que a educação era prioritária, e eles estavam dispostos a financiar a construção de prédios, mas para isso era preciso uma nova forma de administração. Então nesse momento se discutiu eu, o grupo todo e a Secretaria de Educação a necessidade de se criar um Fundo Estadual de Construções Escolares. E aí eu fiquei encarregado de criar esse Fundo. Aí eu montei a equipe, criei o Fundo. Tudo foi criado rápido, decreto do Plano de Ação, fazia parte do Plano de Ação. Esse fundo foi criado, eu assumi a direção como presidente do Fundo, montei a equipe, e passei o Fundo para o professor Pasquale, que saía da Secretaria por razões políticas e era preciso dar alguma coisa para ele, e ele tomou meu lugar, e ficou diretor executivo do FECE.1960. Trabalhava no FECE Flávio Villaça, Clementina de Ambrósio, Mayumi Souza Lima. Esse pessoal todo trabalhou no FECE levado por mim e nós iniciamos no FECE um trabalho sistemático de produção com um novo método de trabalho. Porque antes quem construía era o DOP, Departamento de Obras Públicas do Estado, com projetos padrões, que a gente chamava o grande carimbo da escola, e as necessidades. E o FECE passou a ter total autonomia, vinculado diretamente ao secretário e ao Plano de Ação, de forma a atender a meta do Plano de Ação que era construir, em quatro anos, três anos e meio nessa altura, uma quantidade substancial de escolas e salas de aula de ensino médio e primário. E passaram então as equipes do FECE a estudar e fazer o levantamento, estudar a situação da rede pública estadual. E eu sabia da existência, você deve ter se informado também, que na capital de São Paulo a rede escolar estadual, controlada pelo aspecto prédio, por um grupo que chamava Convênio Escolar, que trabalhava 
o arquiteto Hélio Duarte, que trabalhou o professor Mange e outros professores. Esse Convênio Escolar tinha uma certa autonomia porque era um convênio. Porque chamava Convênio Escolar? Era um convênio do Estado com a Prefeitura de maneira a que a rede estadual... A rede pública era basicamente estadual, e essa rede pública deveria receber da prefeitura os prédios e o Estado montaria os seus diretores, funcionaria... A operação seria a cargo do Estado. A prefeitura ficou na mão do médico Vladimir de Toledo Piza, em 1957, certo. Foi esse médico Vladimir, que era do PTB, que contratou SAGMACS e o Lebret para fazer a pesquisa. Então ele ficou oito ou nove meses na Prefeitura, e ele se deparou com o problema da deficiência alarmante de vagas para a escola. Por quê? Porque São Paulo vinha sendo pressionado com imigração colossal, uma expansão geográfica e territorial avassaladora, com uma urbanização intensíssima e precaríssima, onde cada começo de ano letivo aparecia déficits monstruosos de vagas escolares. Por quê? Porque a industrialização e urbanização exigiam uma sociedade letrada. Então não tinha como: todo mundo tinha que tomar ônibus, saber ler, escrever. E essa mudança da década de 50 estoura na mão dele. Isso você pode verificar em qualquer pesquisa em jornal: as manchetes do começo do ano letivo, que eram manchetes espetaculares sobre as deficiências. Então o Vladimir de Toledo Piza vai e não tem outra solução. Ele diz o seguinte: ele publicou no Diário Oficial que toda normalista formada e competente, isto é, com condição de ensinar que arrumasse um lugar para ensinar, uma sala, uma garagem, algum lugar, e que trouxesse uma lista de 40 alunos seria admitida como professora da Prefeitura, e seria paga como professora da rede municipal. Foi aí que ele montou o começo da rede municipal. Que não tinha.

(M) Da rede exclusivamente municipal?

(C) Exclusivamente municipal! Eles assumiam tudo. Porque antes só tinha o Convênio. Não tinha uma rede municipal. Não tinha a categoria de mantenedora de um ensino primário. Tinha outros tipos, de creche, outras coisas, outras atividades. Que eu saiba, não tinha. Pode até ser que tivesse alguma pouca coisa, não é? Então se estabelece aí, a partir daí a rede de ensino primário municipal, em barracos, em garagens, e ele passou então a reivindicar uma nova forma de construção. Então em 1959, 60 você já imaginou como é que estava a situação do ensino no estado de São Paulo, especialmente da área de grande expansão demográfica.

(M) E que continuou a crescer.

(C) Ah, sim, continuou e não parou. Então, no Plano de Ação se estabeleceu, eu me lembro até hoje, que nos três anos e meio do governo, que faltava dos quatro anos do Carvalho Pinto seriam construídas seis mil salas de aula no estado. E para fazer isso, era preciso agilidade, padronização, equipe autônoma, recursos próprios e independência total da morosidade do aparato estatal, isto é, do funcionalismo público. Então o FECE, Fundo Estadual de Construções Escolares inicia o seu trabalho na década de 60, e vai montar planos anuais de construção assim, a rodo, com contratados, arquitetos. Deram então trabalho para rodos de arquitetos. E os programas, a escolha do terreno, e todo o processo, desde o levantamento das necessidades, através de pesquisas intensas, e a autonomia da Secretaria em termos de intervenção política. A intervenção política se dava diretamente do governador. Por quê? Porque quem decidia aonde ia se construir era o Plano de Ação que ficava no Palácio, com a assessoria e o trabalho desenvolvido pela equipe do FECE. Então aí começa o trabalho em 60, porque 59 teve alguma coisa, mas eu acho que ele foi instalado em meados de 59. Então 60, 61 e 62 o FECE trabalhou intensamente para construção dessas salas de aula, e ensino primário e ensino médio. Então eram prédios dos grupos escolares e os prédios dos colégios, dos ginásios e colégios. Aí houve uma total, eu tenho impressão que a rede física recebe um contingente de prédios novos, substituindo os antigos e redefinindo processos de escolhas, escolha de bolsões de necessidade, condições de escolha do terreno, que aí se pedia à Prefeitura para dar aquele terreno, para comprar e doar. Os projetos eram feitos por encomenda, como o são até hoje. Hoje, o que é hoje, o FECE, FDE seu nome, não é?, começou lá, depois houve uma transformação, outros organismos, depois virou FDE. E com possibilidade de receber recursos federais e de recursos de ajuda estrangeira, diretamente. Com o treinamento do pessoal para planejamento escolar, e eu passei então a ser um especialista nacional em planejamento educacional. Depois fui assessorar o governo federal, governo do Jango Goulart. Eu era um dos assessores do ministro sobre o programa da Escola Brasil. Mas isso durou pouco tempo, porque aí veio a revolução [de 1964]. O que eu posso te dizer é o seguinte: é que quando nós entramos para fazer o Plano de Ação o Convênio escolar não existia mais. O que existia era uma prática que o Jânio Quadros tinha estabelecido, mas eu tenho impressão que não funcionou na Grande São Paulo, que era o IPESP, você já ouviu falar do IPESP? 
(M) Sim.

(C) O IPESP estava com dinheiro sobrando, no sentido de receber, e não sabia como aplicá-lo. Então o Jânio fez, falou "Não, a melhor aplicação", provavelmente falou assim, "seriam imóveis". "Então vocês constroem grupo escolar que o Estado aluga de vocês". Então eles construíram alguns. Eu tenho impressão que na Grande São Paulo ele não construiu, mas no interior era muito comum. O IPESP comprava o terreno e construía.

(M) O Instituto de Previdência do Estado de São Paulo.

(C) Não tinha nada que ver com isso. Então quando nós entramos, tinha os prédios do IPESP, prédios do DOP, que quem decidia onde construir era diretamente o arcabouço político, as influências.

(M) Agora, já voltando para sua atuação especificamente, você sempre falou muito em método de atuação, dentro do FECE, a implantação de um método. E me interessa muito a relação entre o método desses, nem sei se vai dar tempo seja um assunto mais demorado, talvez até valha a pena dar uma lida nisso aqui, mas é algo que talvez mais tarde a gente poderia aproveitar para conversar. Até que ponto esse método macro de pensar a rede escolar influencia o projeto arquitetônico?

(C) Mas esse era o problema que a gente discutia. Por quê? Porque acontece o seguinte: um planejamento da rede é o planejamento do quê? Das condições físico-materiais para a implantação de um sistema educacional. Então, eu tenho que saber como é o sistema educacional. O sistema educacional é dividido como? É obrigatório, não é obrigatório. Atende aqui a área. Então quando nós assumimos, havia uma maneira arcaica de se pensar a educação. A educação foi se transformando e evoluindo sem nenhuma grande pressão popular. Porque a educação do começo do século era uma educação para a elite. A grande população morava na zona rural. Se você pegar a década de 30 você vai ver que a população urbana era reduzidíssima e a população rural não precisava de grande formação. Não precisava para os grandes coordenadores. E como que funcionava. Funcionava no esquema das escolas isoladas do mestre. Era o mestre que era um funcionário público e reunia os seus. Meu pai e minha mãe foram professores no sertão do estado onde eu nasci, onde eles iam dirigir as classes, as pequenas vilas das zonas rurais, etc. E por que chamou grupo escolar? Porque era um grupo de escolas isoladas, chamava escola isolada, que quando crescia um pouco a população, a unidade de ensino não era mais a classe do professor múltiplo que dava aula no primeiro, segundo, terceiro ano rural. Ele sozinho levava para os alunos de três níveis diferentes: alfabetização, iniciação da leitura e da aritmética e terceiro ano para a formação um pouco mais. Então eram três anos de escola rural. Quando crescia um pouco o número de escolas, elas eram reunidas em um grupo escolar. Um grupo de escolas isoladas que era então a divisão dos alunos em séries. Essa é origem do sistema escolar nosso, que eu posso falar em cinco minutos. Mas isso tem estudos... Então o sistema escolar do estado de São Paulo, do seu interior vinha se formando desse jeito. Nas grandes cidades eram estabelecimentos tradicionais, isto é, os estabelecimentos da grande elite. Era o Caetano de Campos. Ou eram os grupos escolares ou eram as escolas de categoria para os moradores aqui. As classes altas do interior, o que faziam? Mandavam seus filhos para os colégios internos. São Bento. Então você vai perguntar: Nestor, onde é que você estudou? Estudei no colégio São Bento. Era o colégio dos jesuítas. Eram os colégios dos carmelitas e que existe até hoje. Só que hoje eles perderam. Então eram duas: era a escola pública da cúpula, da elite, dos moradores das cidades médias e grandes e os colégios internos para os rapazes e as moças que vinham do interior da fazenda, etc., e que se distribuíam pelo interior também. Esse era o sistema do colégio que eu fiz. Eu fiz escola pública. Então 42, 1940, durante a guerra é que se faz o primeiro movimento de democratização da escola pública, que era o movimento do Estadão, do Anísio Teixeira, dos grandes educadores, que, a defesa da escola pública era uma coisa extremamente importante na época, um grande movimento, anticlerical, liberal, era uma forma da antiga UDN. Então era uma coisa, que eram reacionários, mas progressistas. De direita, mas eram progressistas, era um sentido de modernidade. Esse primeiro período que foi a grande força da escola pública para a democratização. E aí ampliaram a rede do ensino público. Mas com o grande cuidado de não perder a qualidade. E com isso eles faziam a seleção. Então, expansão do ensino primário para todos, essa era a regra. E ensino ginasial e ensino médio para os melhores. Então, você saía do grupo escolar, fazia o exame de admissão para entrar no ginásio, e houve alguma tentativa de democratizar isso também, e abrir um pouco mais a entrada para o ginásio. Mas isso não dava muito certo. Logo ficava meio superlotado. Mas o que acontece aí? A urbanização avassaladora, isso você pode ver aqui mesmo, nós falamos nisso... 
(M) População rural, população urbana.

(C) Você vai ver que a população rural continua a mesma. A população urbana é que explode. Então, é um negócio impressionante. Então eu fui o pioneiro do planejamento urbano, no sentido mais global. Porque se falava no plano da escola, mas sempre da atividade ensino- aprendizagem, não no sistema escolar. Sistema supõe quem mantém, quem faz o prédio, todo o conjunto para montar. Então, nessa altura eu passei a dar curso, a estudar, a ler, a juntar equipe. E quando nós montamos a EDAP, que era essa assessoria, Educação e Planejamento, tinha uma equipe complexa que começava a fazer trabalhos, assessorando a montagem desde rede de ensino de um conjunto habitacional, até programa educacional de uma faculdade ou de uma universidade. Isso durou pouco tempo, também por causa do problema das mudanças... Então sobre o Convênio escolar, eu posso te dar muito pouca informação. Sobre a parte da constituição da nova maneira do governo do Estado produzir a rede escolar eu posso te dar informações. Sobre o método de planejamento, aí é uma adaptação de uma formação nova, da aplicação de tudo que se falava em planejamento urbano, em planejamento econômico. Aí se discutia se educação era investimento ou não. Por quê? Porque o desenvolvimentismo falava: só pode se desenvolver se houver investimento. Esse era o papo. Aí nós tínhamos que provar que educação era investimento para receber recursos. Nesse período aparece uma série de reuniões internacionais sobre planejamento urbano. A primeira reunião foi em Washington. Essa eu não fui. Depois a CEPAL montou uma grande organização sobre isso. 
Anexo B

Projetos de escolas públicas 
Os desenhos de projetos colocados a seguir foram obtidos no arquivo da EDIF-PMSP, porém foi confirmado que o arquivo não contém todos os projetos feitos pela Prefeitura no período analisado por esta tese. Os projetos foram agrupados por datas e por um critério de separação pelo órgão público responsável por sua fatura. Algumas das escolas citadas no corpo principal da tese não foram encontradas no arquivo da EDIF, mas sim em publicações da época, principalmente em periódicos. Somente os desenhos obtidos no arquivo da Prefeitura foram incluídos neste anexo. Não foi possível verificar se havia algum cadastro completo de plantas e demais desenhos das escolas nos arquivos da Prefeitura, de modo que a lista indicada é resultado de levantamento dos próprios desenhos e das informações neles contidas. Há um cadastro de projetos, porém desatualizado e legível apenas para os iniciados.

Os desenhos estão organizados primeiro por época, em dois grupos (1934-1948 e 1949-1958), e dentro de cada época estão colocados na seqüência numérica indicada nas folhas dos projetos. Essa seqüência não corresponde a uma cronologia da realização dos projetos. As datas encontradas nos desenhos também variam com alguma freqüência, pois um mesmo projeto, um ou dois anos após a sua elaboração - e às vezes alguns meses depois - já sofria alguma reforma ou ampliação. Isso confirma que não há, na maioria dos casos, um desenho original, primeiro e a partir do qual as transformações se sucedem em reformas. $\mathrm{O}$ que ocorre é uma sobreposição de projetos e alterações nos mesmos, inclusive durante a execução. Essa prática parece ter sido comum em face da necessidade de escolha de materiais que fossem baratos e que também atendessem às especificações dos arquitetos. 


\section{Anexo B}

\section{Projetos realizados entre 1934 e 1948}

Os projetos realizados nesse período, e que foram identificados na pesquisa feita no arquivo da EDIF, foram feitos principalmente pela Diretoria de Obras Públicas (D.O.P.) do Estado de São Paulo e pelo Departamento de Obras Públicas da Prefeitura de São Paulo. Apesar disso foram incluídos neste trabalho porque fazem parte da rede física da cidade e neles se encontra o início da aplicação de conhecimentos técnicos e científicos, além das novas propostas pedagógicas, na arquitetura de escolas públicas, o que se tornaria uma referência fundamental nos projetos desse tipo de edificação a partir de então, por cerca de 30 anos. Muitas dessas edificações foram reformadas pela CE. 
Padre Manoel da Nóbrega (D.O.P. 1)
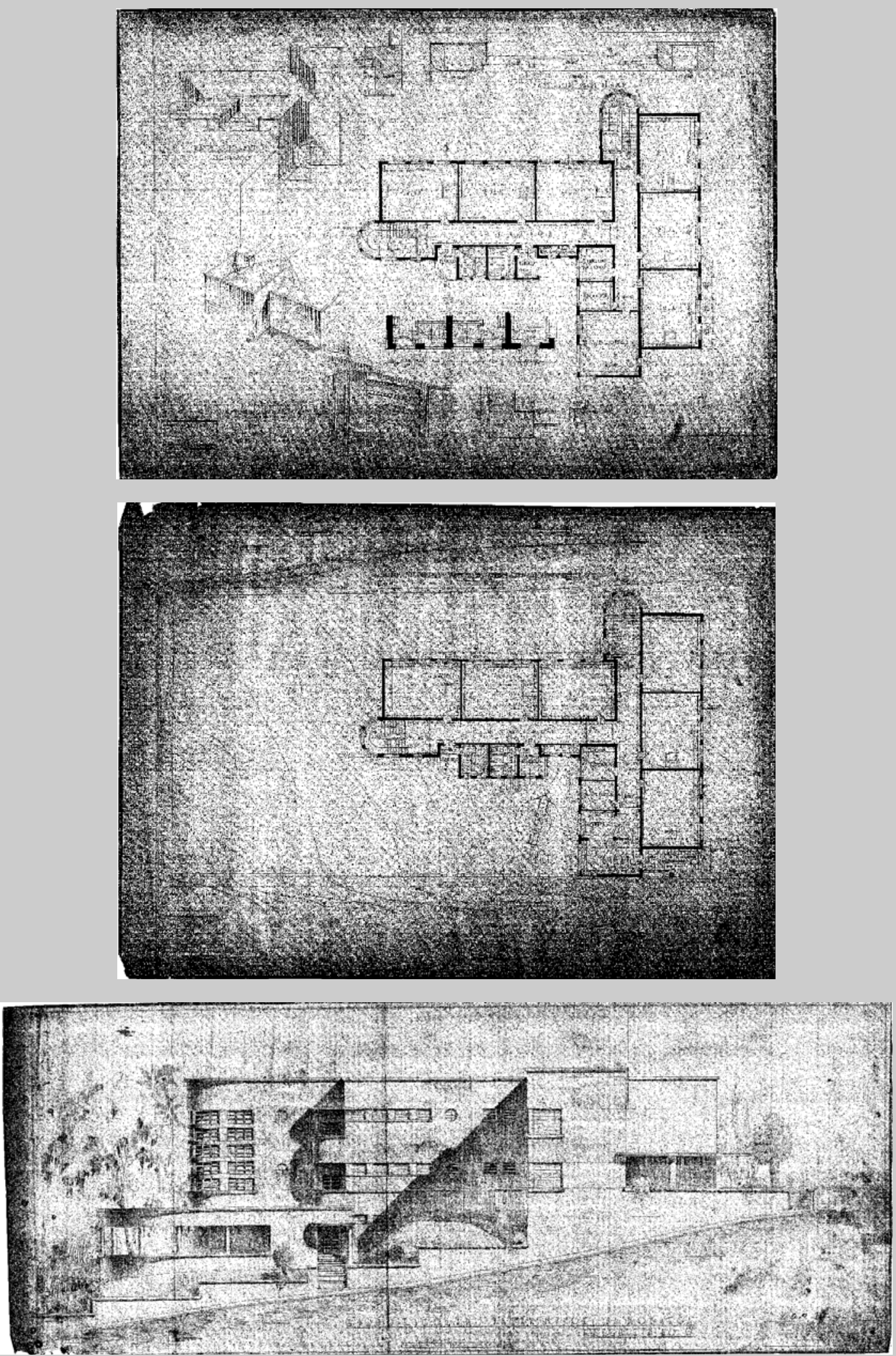

Projeto de 12 de agosto de 1938, de autoria de H. Penteado (?). Foi reformado em 1949, já durante o funcionamento do segundo Convênio Escolar. É um dos projetos com volumetria mais interessante dentre os que foram encontrados. 
José Bonifácio (D.O.P. 25)
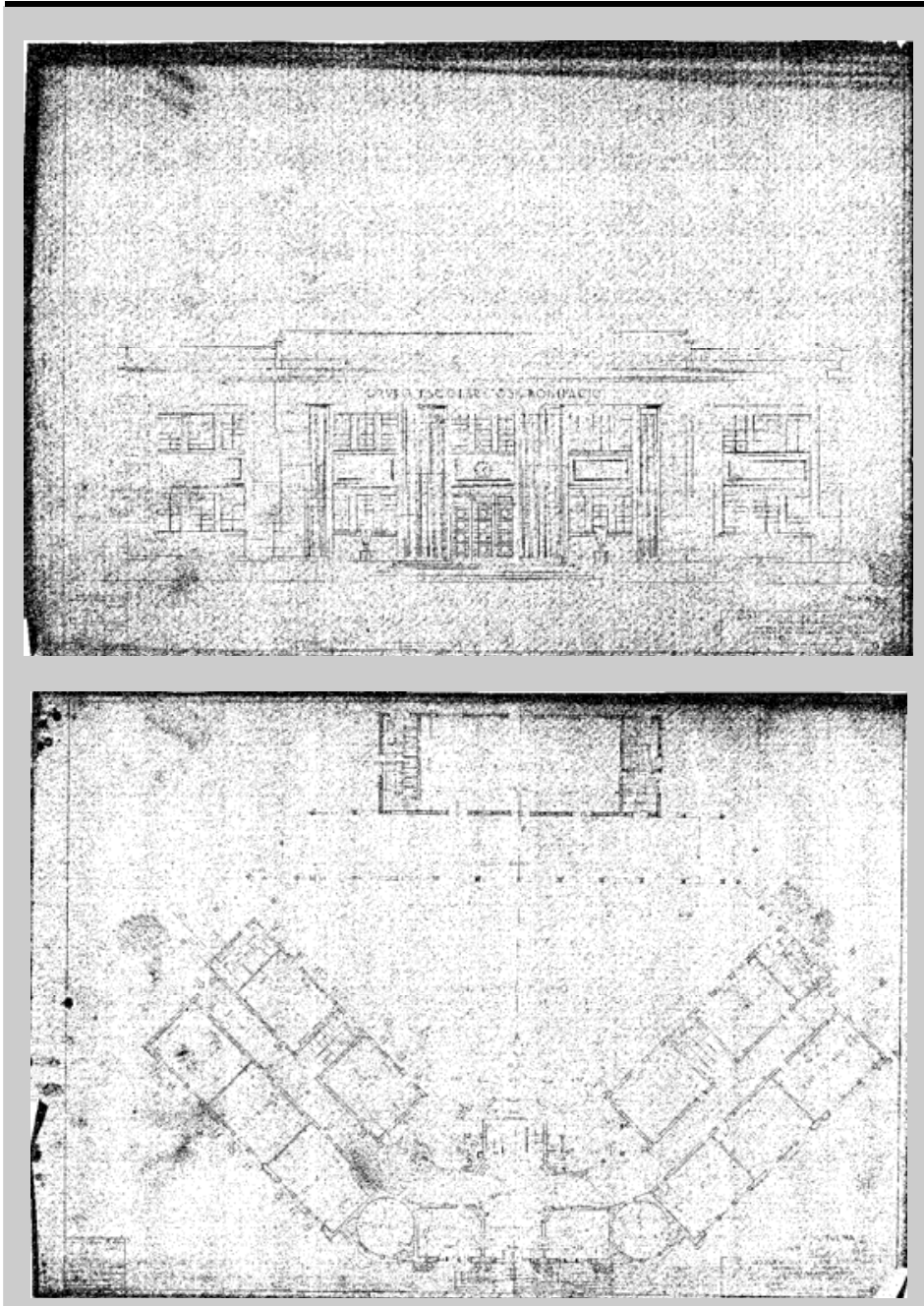

Projeto feito entre maio e junho de 1937, por José Maria da Silva Neves.

Foi reformada pela CE. As

características da escola sugerem uma composição muito mais próxima de um classicismo racionalista, tal como foi desenvolvido por Marcello Piacentini, do que para o Art Déco que comparecia na maioria de seus projetos para escolas da época.

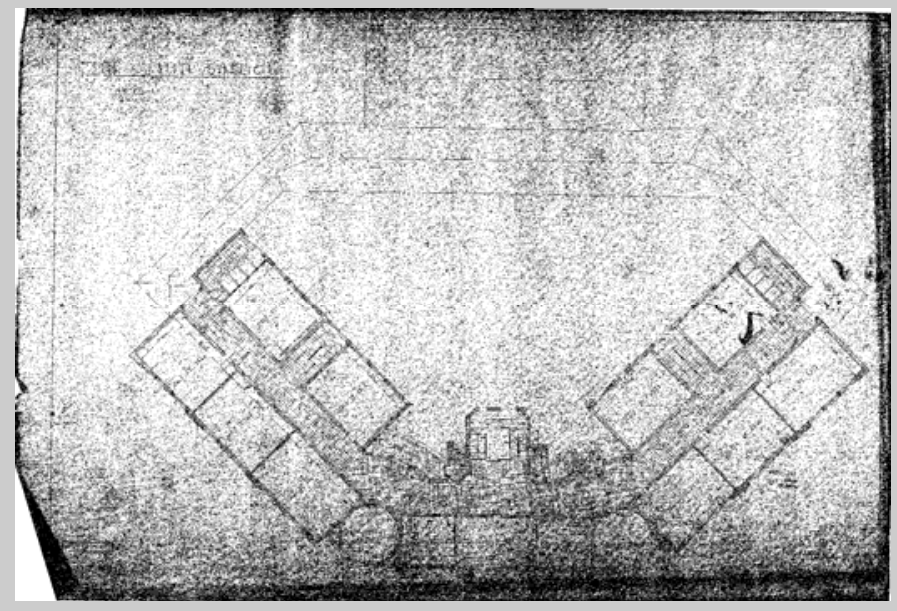


Oscar Thompson (D.O.P. 43)

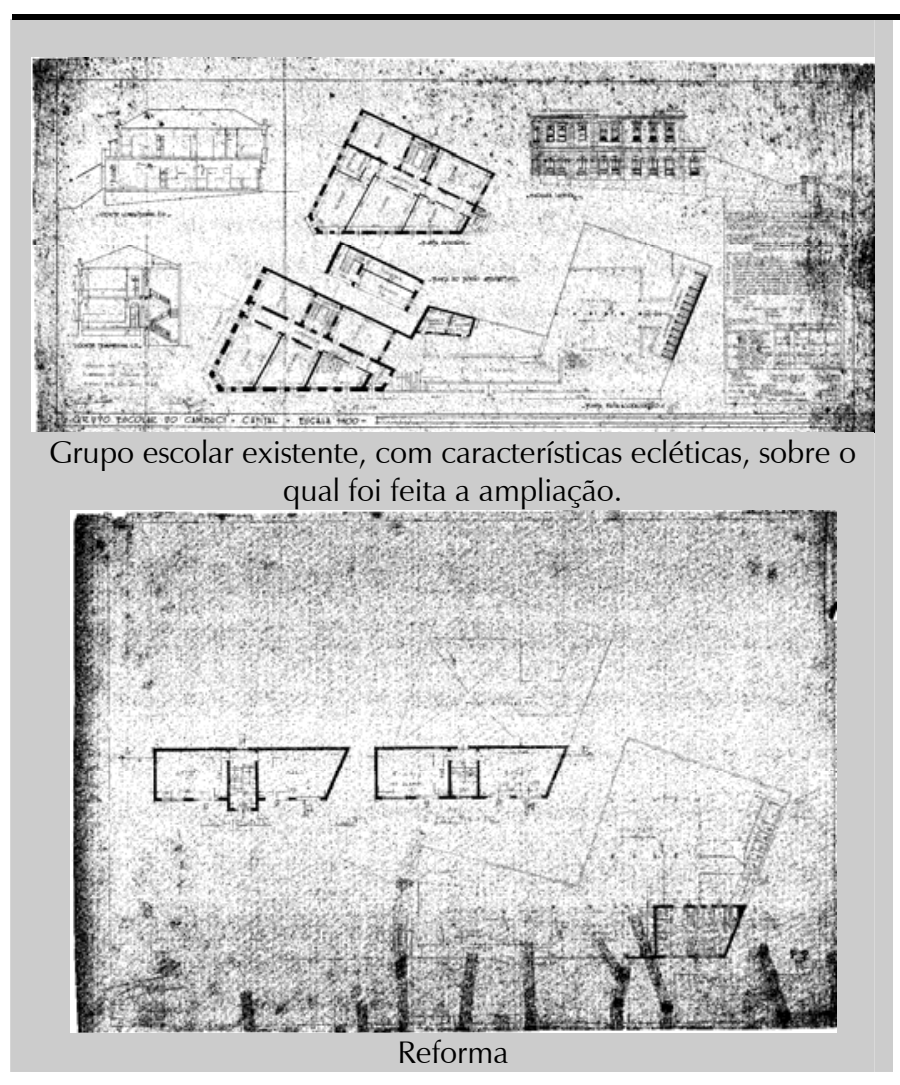

Trata-se de uma extensa reforma e

ampliação, com projeto de Paganelli, com características Art Deco, feita sobre o grupo escolar do Cambuci, em 1944.

Antonio Queiroz Telles (D.O.P. 51)

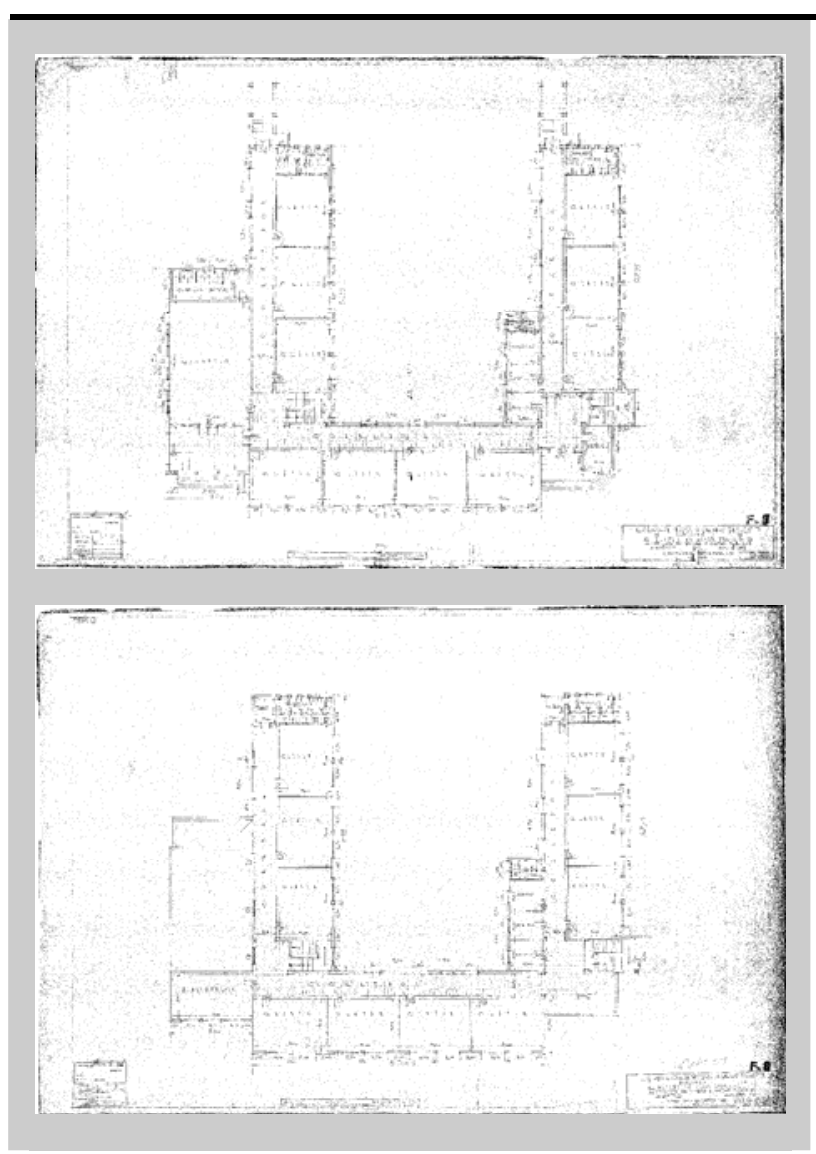

O projeto foi feito entre o final de 1937 e início de 1938, e é da autoria de José Maria da Silva Neves. Esse é um dos projetos de Neves em que se pode confirmar que o zoneamento por usos não se sobrepõe à volumetria da edificação: as diversas salas não se separam exclusivamente. Há uma convivência entre os diversos ambientes em torno de uma organização espacial em que a insolação e a linearidade dos blocos são mais importantes. 
Sacoman (D.O.P. 52)

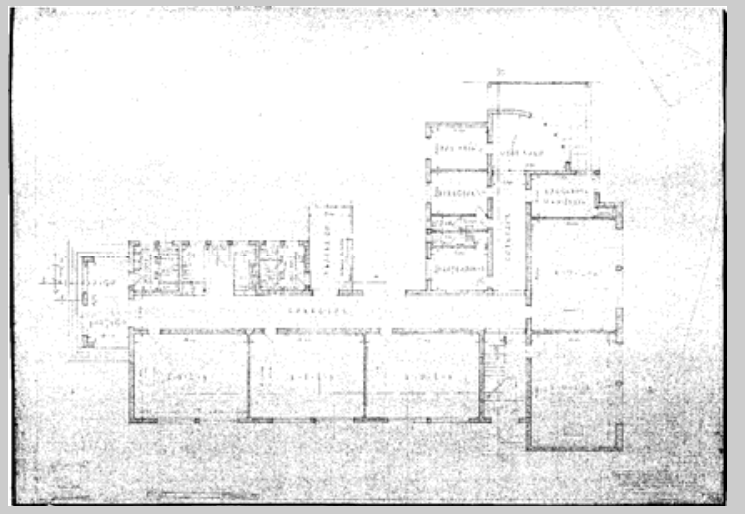

Projeto de 17 de março de 1937. Foi feito sobre uma edificação que foi demolida. A autoria é de José Maria da Silva Neves. Um dos projetos mais simples, porém muito bem articulado e com uma clara hierarquia espacial.

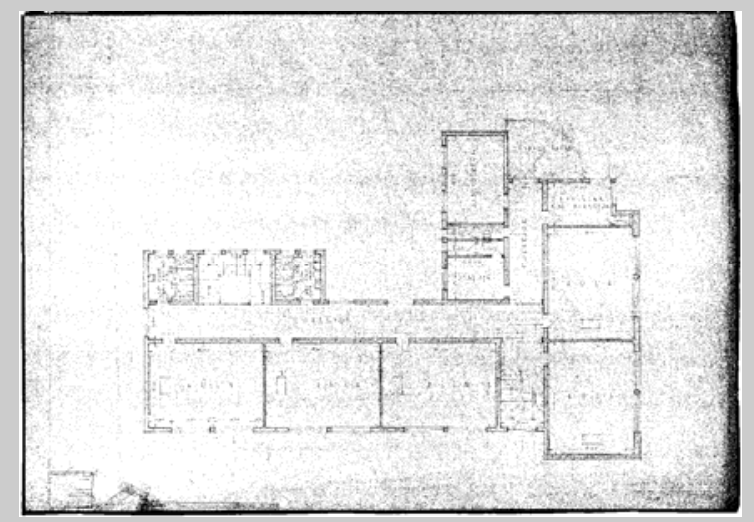

Pedro Arbues (D.O.P. 60)

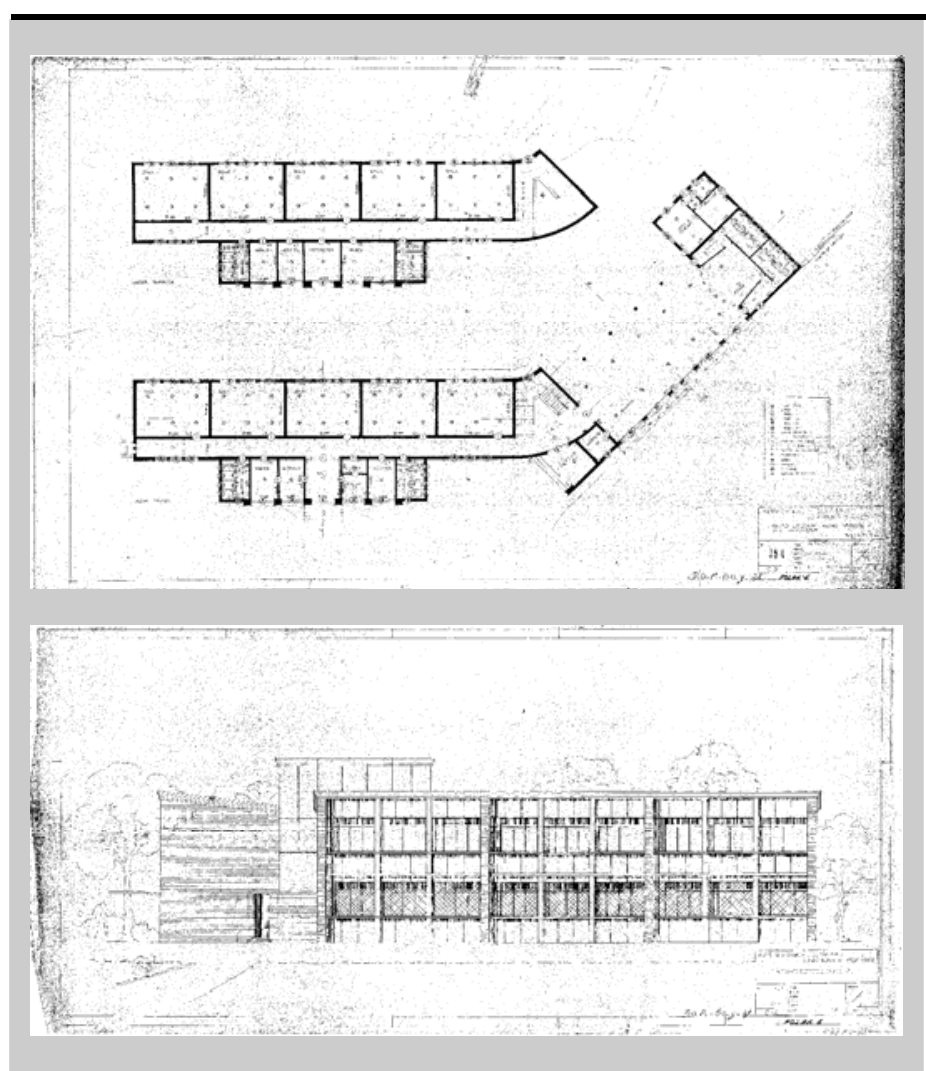

Projeto de 11 de setembro de 1948 e reformado em 1954 e 1955. Não foi possível confirmar a autoria. O projeto mantém as diretrizes da época, porém sem uma hierarquia dos usos. A forma da edificação é prioritariamente definida pela sua linearidade e pelo corredor central. 
Mário de Andrade (D.O.P. 65)

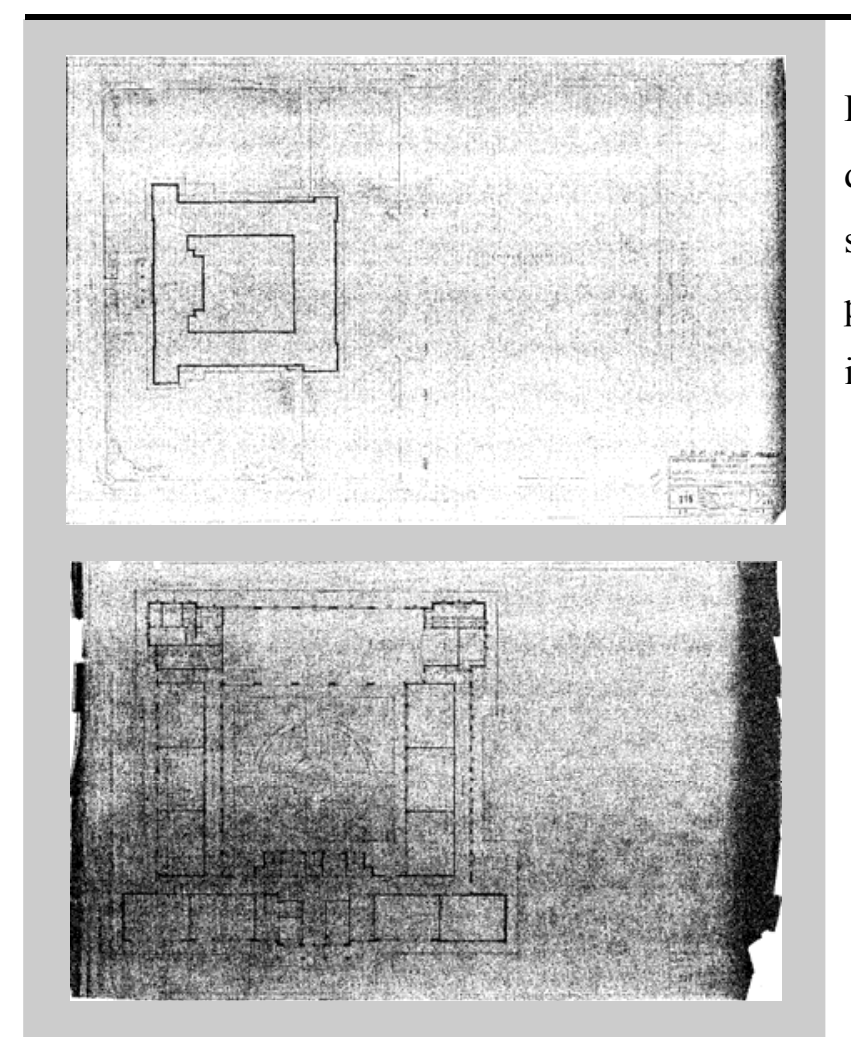

Desenhos datados de 8 de agosto de 1947 e de 10 de maio de 1948. A autoria é de Ghaesela. Notese que o projeto foi feito durante a vigência do primeiro Convênio Escolar e pouco antes do início do segundo Convênio Escolar.

Marechal Bitencourt (D.O.P. 66)

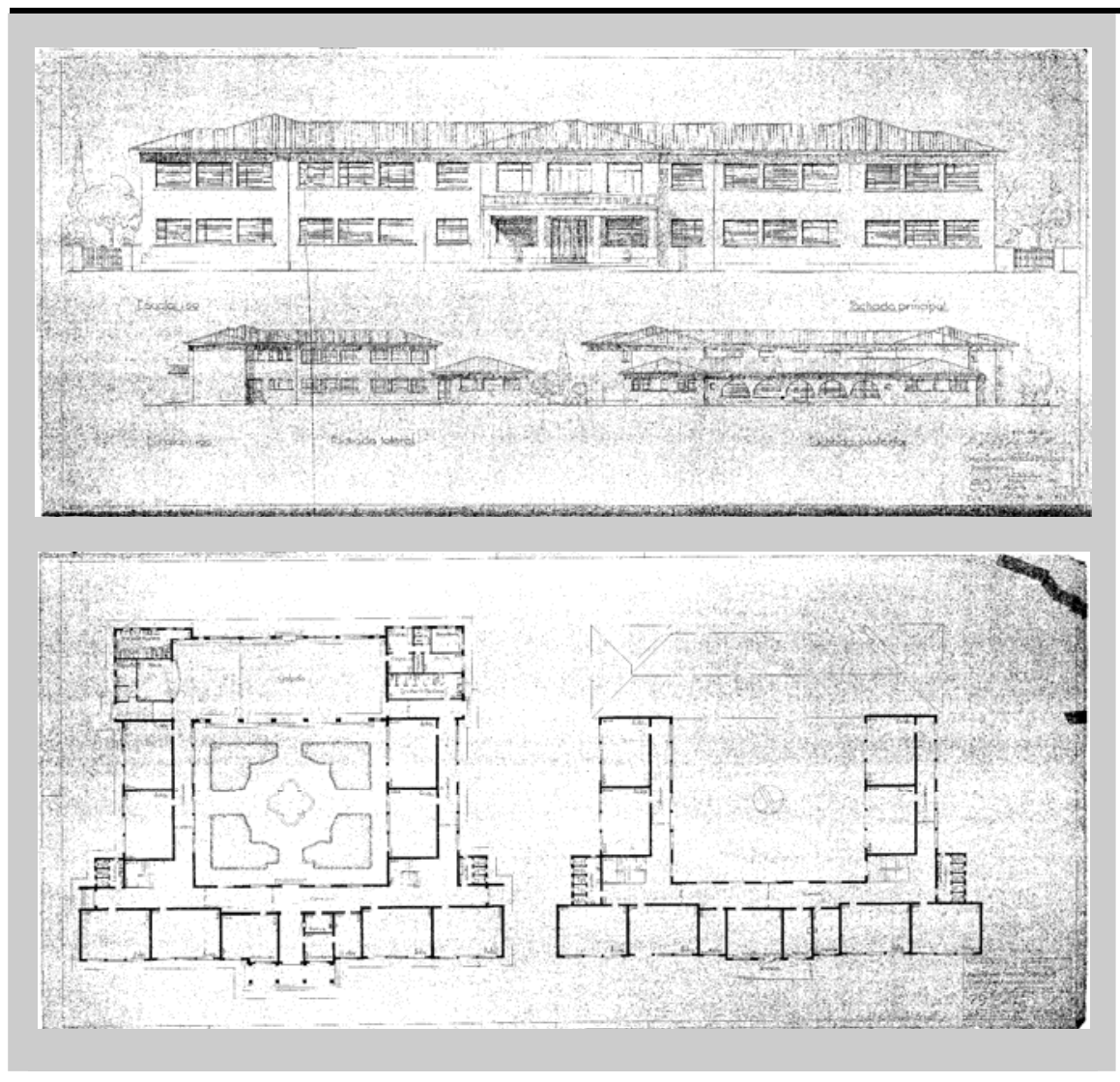

A data do projeto é de 1948 e a autoria é de João del Nero. O pátio central aberto, com o edifício percorrendo seu perímetro, a volumetria coroada por um telhado e sua simetria demonstram que o Art Déco não era hegemônico na definição da arquitetura das escolas. 
Visconde de Itauna (D.O.P. 69)

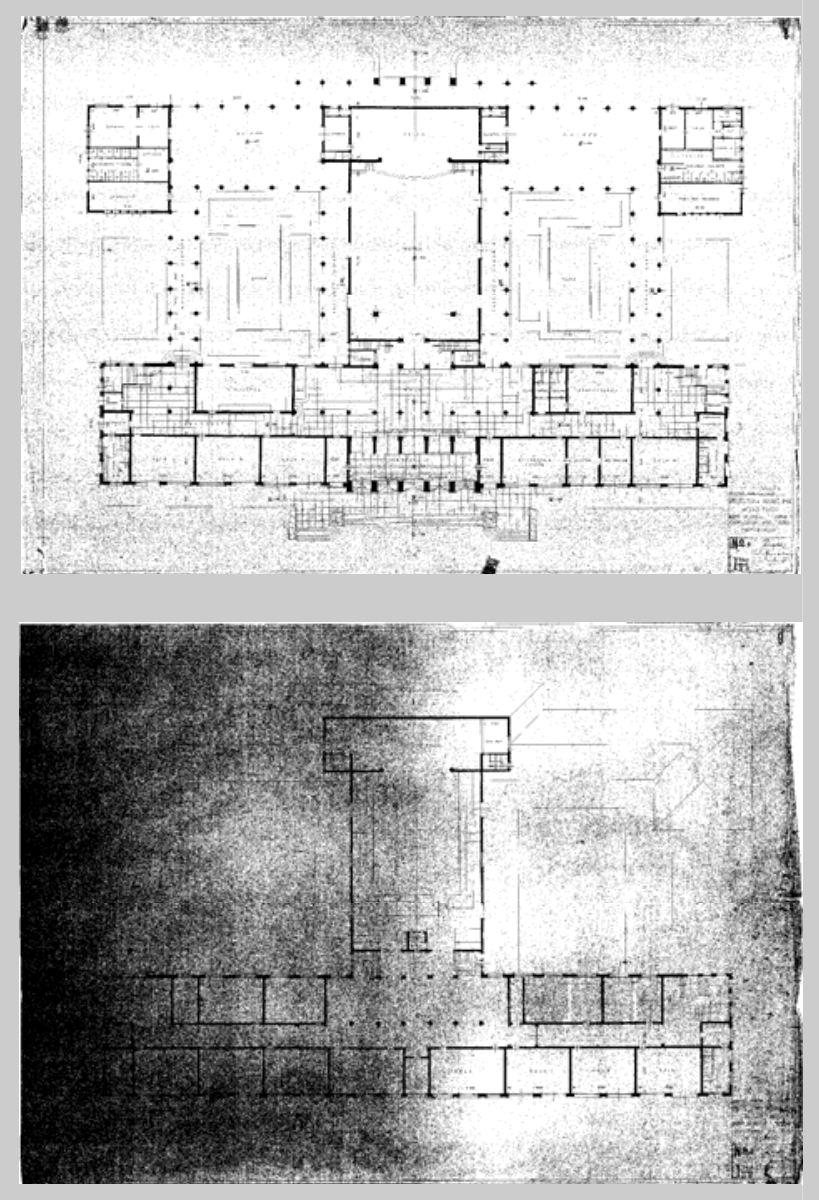

O projeto foi feito entre agosto e outubro de 1947. Há um desenho desse projeto que contém a no carimbo a inscrição "Prefeitura de São Paulo - Departamento de Arquitetura". Foi a única indicação desse tipo encontrada em projetos anteriores a 1948.

Prof. Theodoro Moraes (G. E. 94)

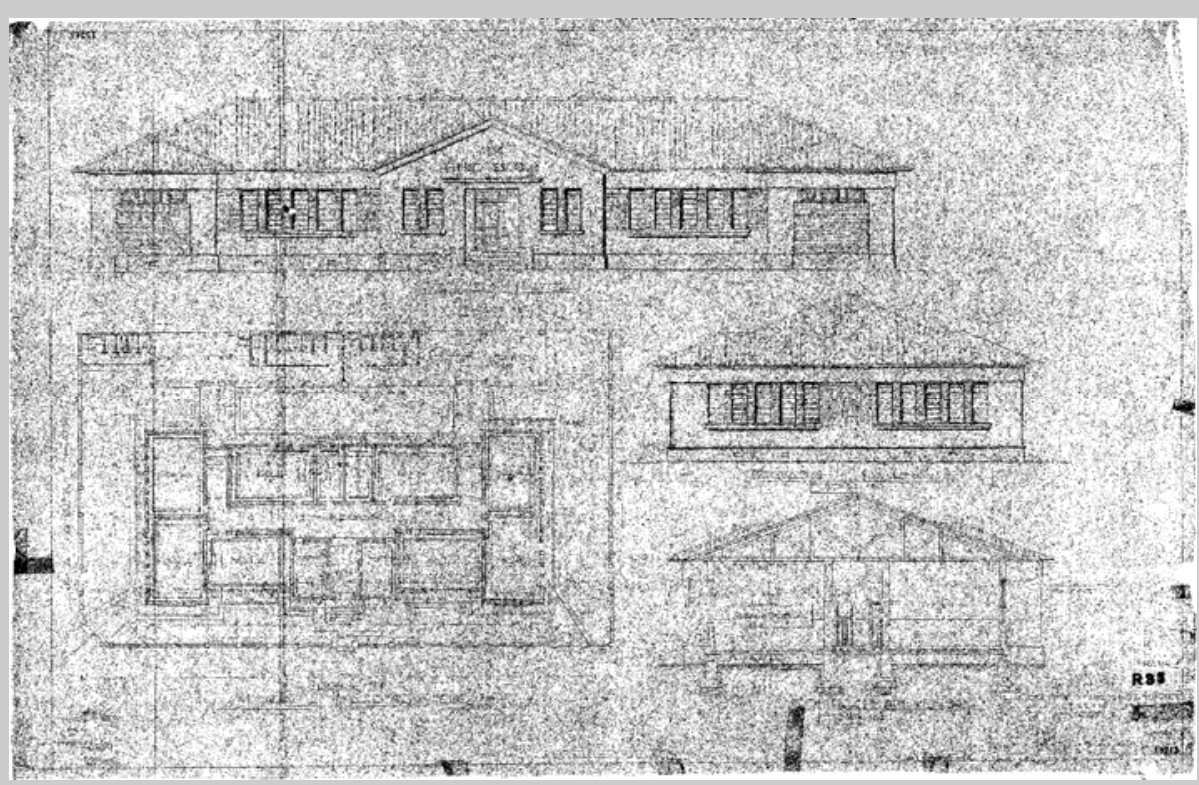

A identificação desse desenho no arquivo foge à regra, a qual também não é muito precisa. O projeto é de 1936 e sofreu várias reformas, e é semelhante ao G. E. Marechal Bitencourt (D.O.P. 66). 
Bosque da Saúde (D.O.P. 96 e D.O.P. 30)

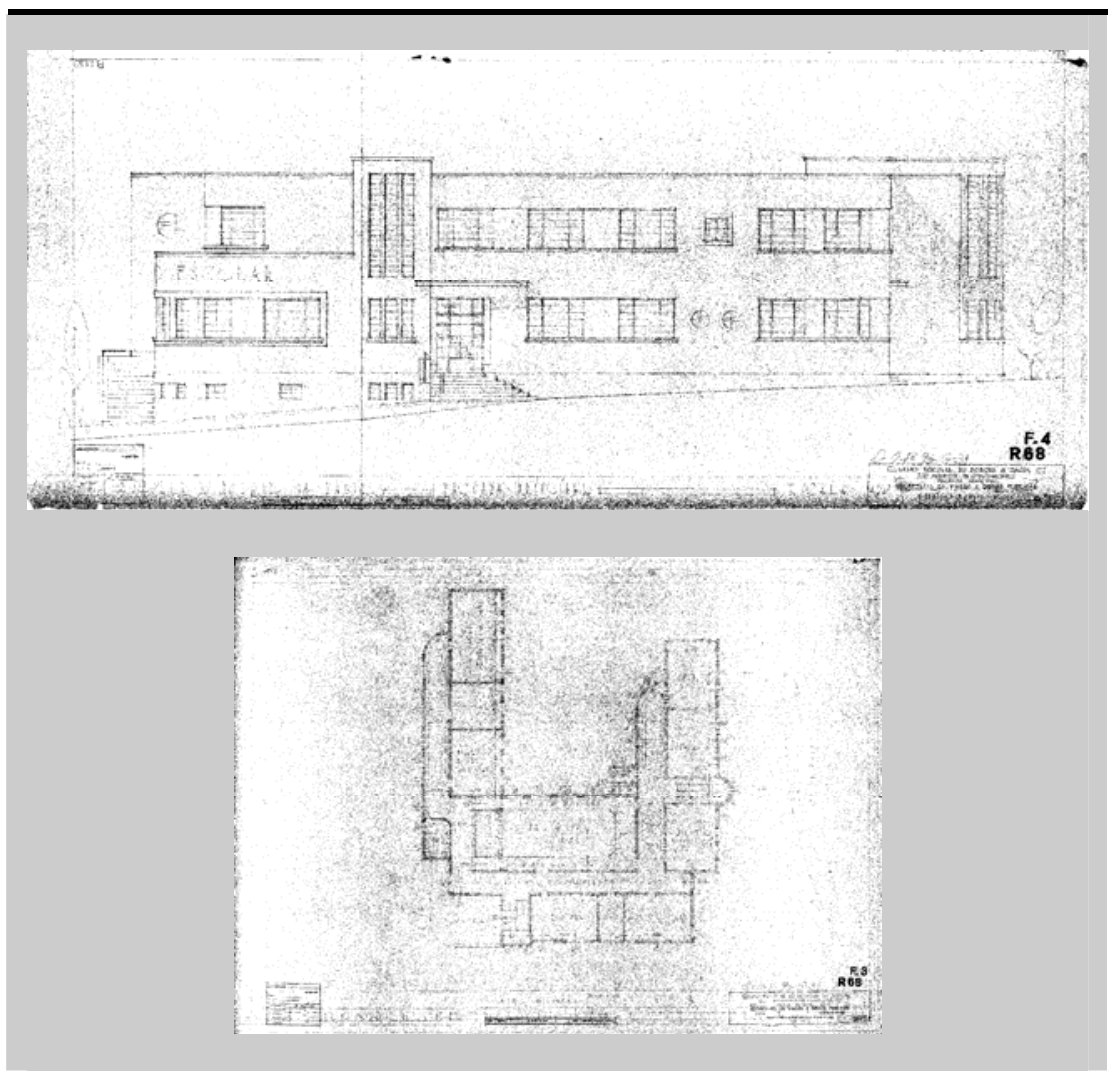

A data é de 30 de janeiro de 1936, com o projeto feito pelo onipresente José Maria da Silva Neves, com as mesmas soluções arquitetônicas.

Vila Gomes Cardim (D.O.P. 102)

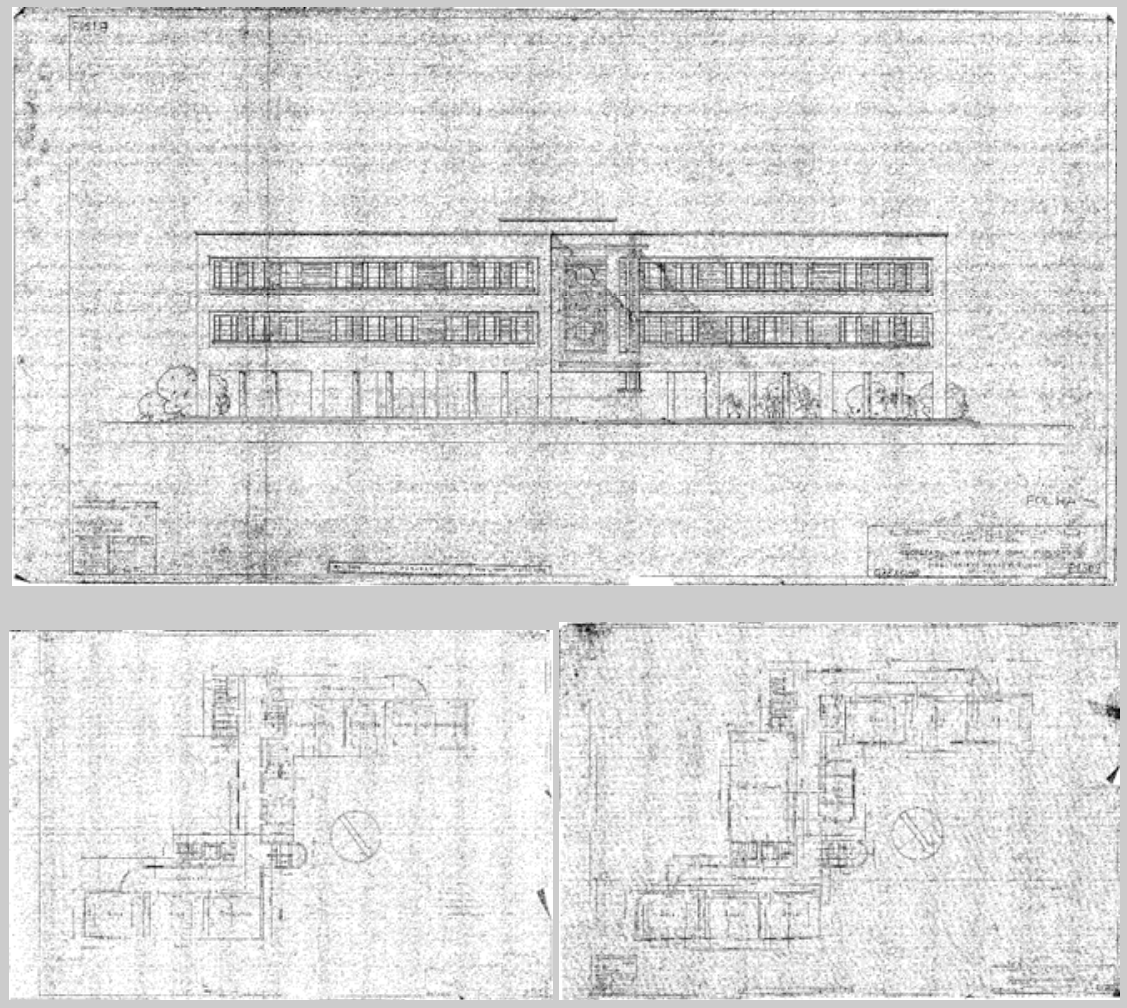

Projeto com data de

27 de fevereiro de 1936, foi feito por José Maria da Silva Neves e Ernesto S. de Freitas. A linearidade dos volumes extrudados se estende longamente nesta construção. 
Anexo B

Projetos realizados entre 1949 e 1958 
Prof. João M. Boanova (G.E. 1)

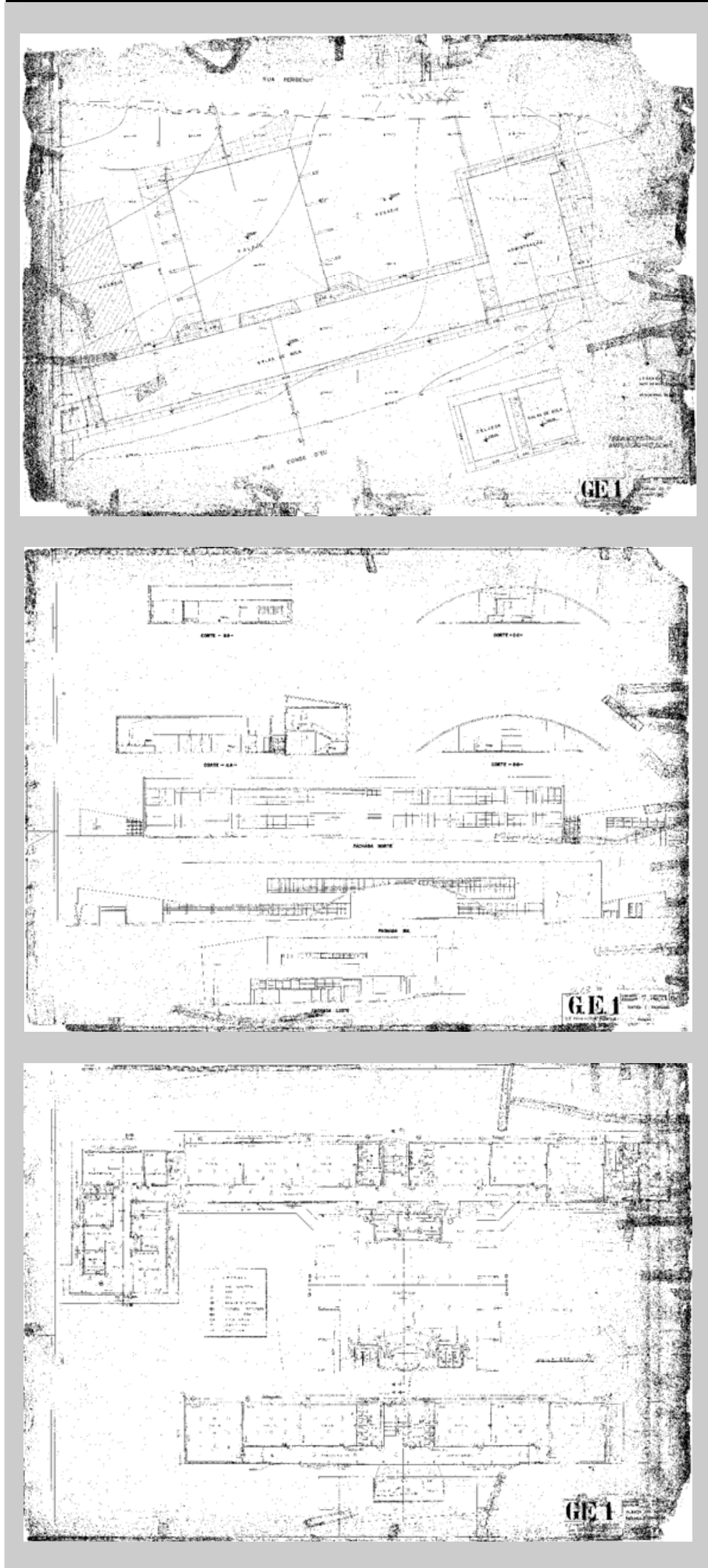

Nesta escola verifica-se a disposição dos quatro setores que vão compor todos os demais projetos realizados pelos arquitetos da CE. O bloco mais longilíneo, no meio da composição contém as salas de aula. Ao seu lado está o galpão e na sua extremidade a área administrativa. Isolado do conjunto estão as dependências de zelador e depósitos. Algumas das soluções construtivas e compositivas deste projeto serão identificadas em vários outros. Note-se que o acesso às salas de aula é feito pelo centro do bloco.

A orientação do conjunto destaca-se da geometria do terreno, pois baseava-se principalmente na insolação: as salas de aula possuem orientação privilegiada. Como conseqüências surgem espaços fragmentados no interior do terreno. Essa situação já foi identificada desde os projetos feitos na década de 1930, apesar do projeto datar de 17 de julho de 1949.

Há uma indicação de modificação com ampliação em dezembro de 1951, para acrescentar espaço para o zelador e uma sala de aula. 
Prudente de Moraes (G.E. 2)
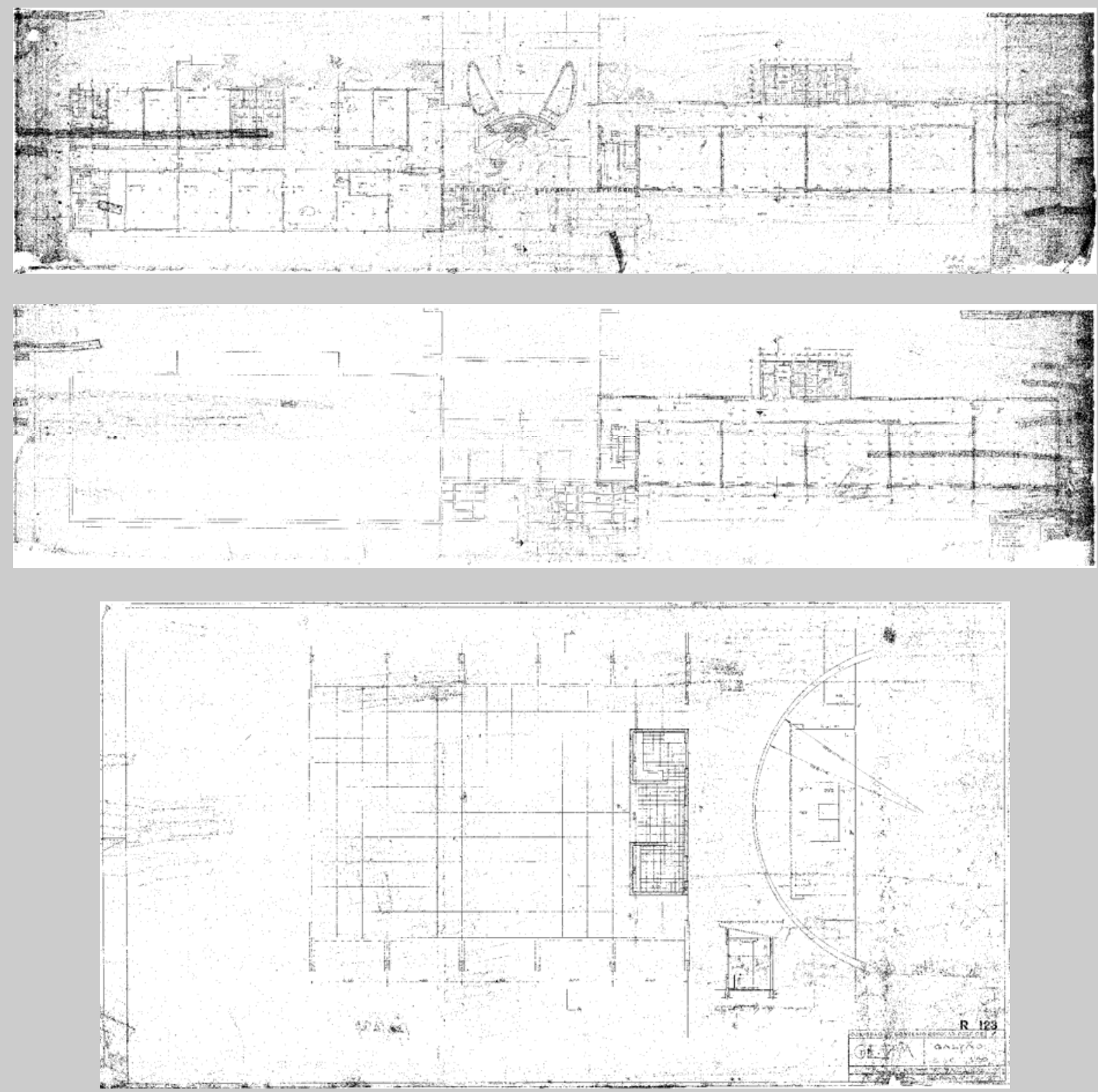

Neste projeto, assim como no G.E. 1, prevalece ainda uma simetria no acesso principal, e a criação de um tipo de recreio coberto, o galpão, com um sistema construtivo e uma organização interna que irá se consolidar como uma solução padrão para inúmeras escolas a partir de então. Há indicações de modificação na planta, algo que era comum naqueles desenhos. 
Brasílio Machado (G.E. 03)

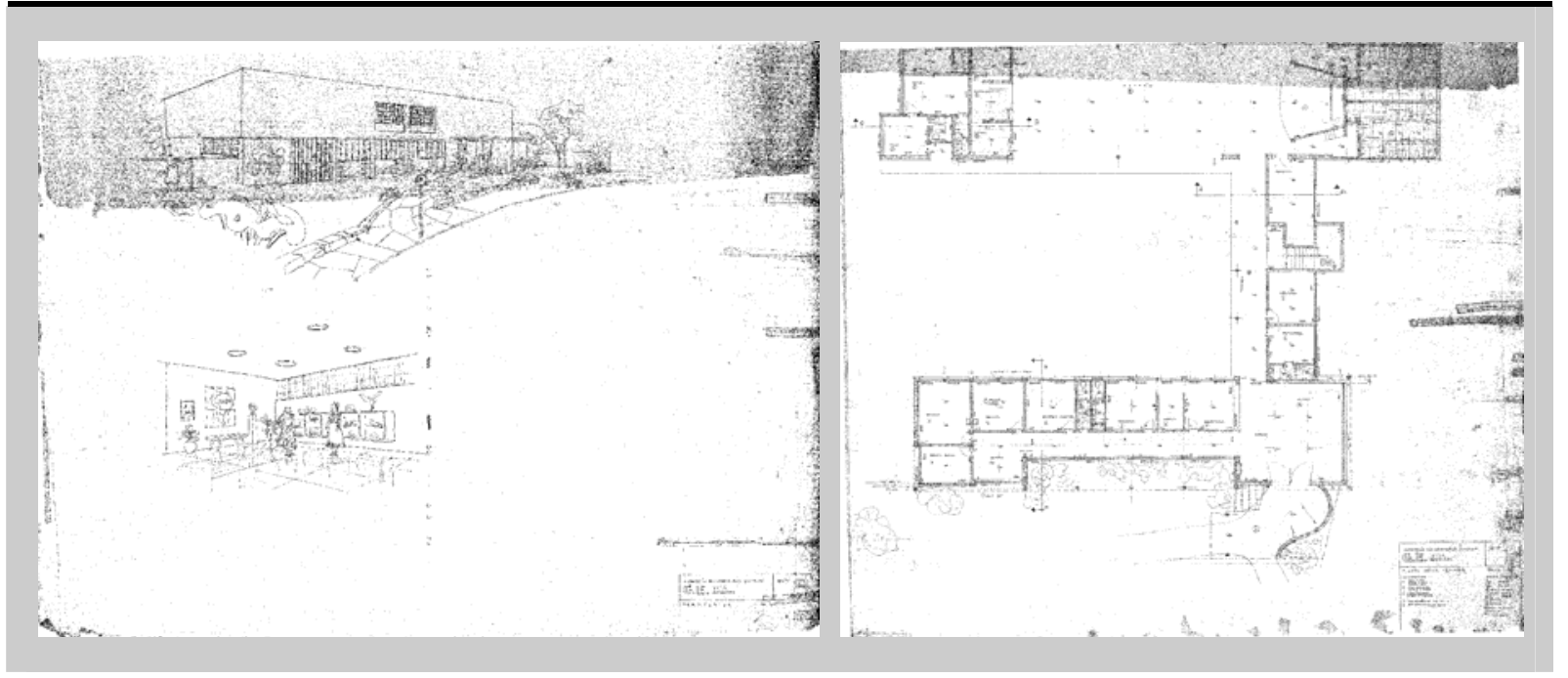

O autor é o próprio Hélio Duarte, em uma solução que cria um espaço interno descoberto. Não há galpão com cobertura exclusiva. Apesar da aparência do projeto estar dentro dos padrões das demais escolas produzidas pelos arquitetos do Convênio, a organização dos volumes e das circulações desse edifício ainda está muito próxima da que era praticada nas escolas construídas durante a década de 1930.

Guilherme Kuhlmann (G.E. 04)

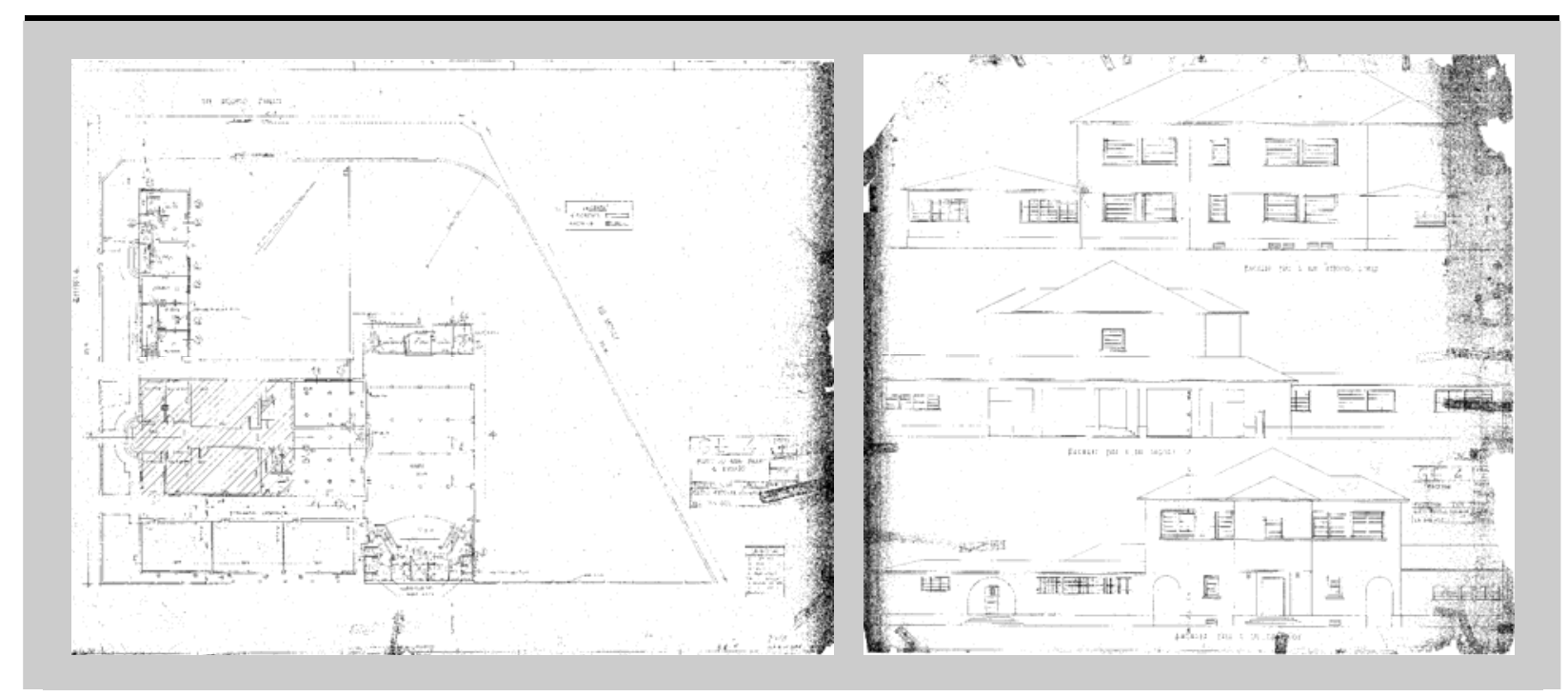

O desenho contém a data de 25 de abril de 1949, do início dos trabalhos da CE. É revelador verificar que se trata de uma reforma e não de um edifício totalmente novo. Importante também é verificar que não houve a utilização de uma linguagem exclusivamente moderna, diferente do edifício existente, com características ainda ecléticas, ao que parece como forma de manter uma unidade do conjunto. 
Pedro Alexandrino (G.E. 05)

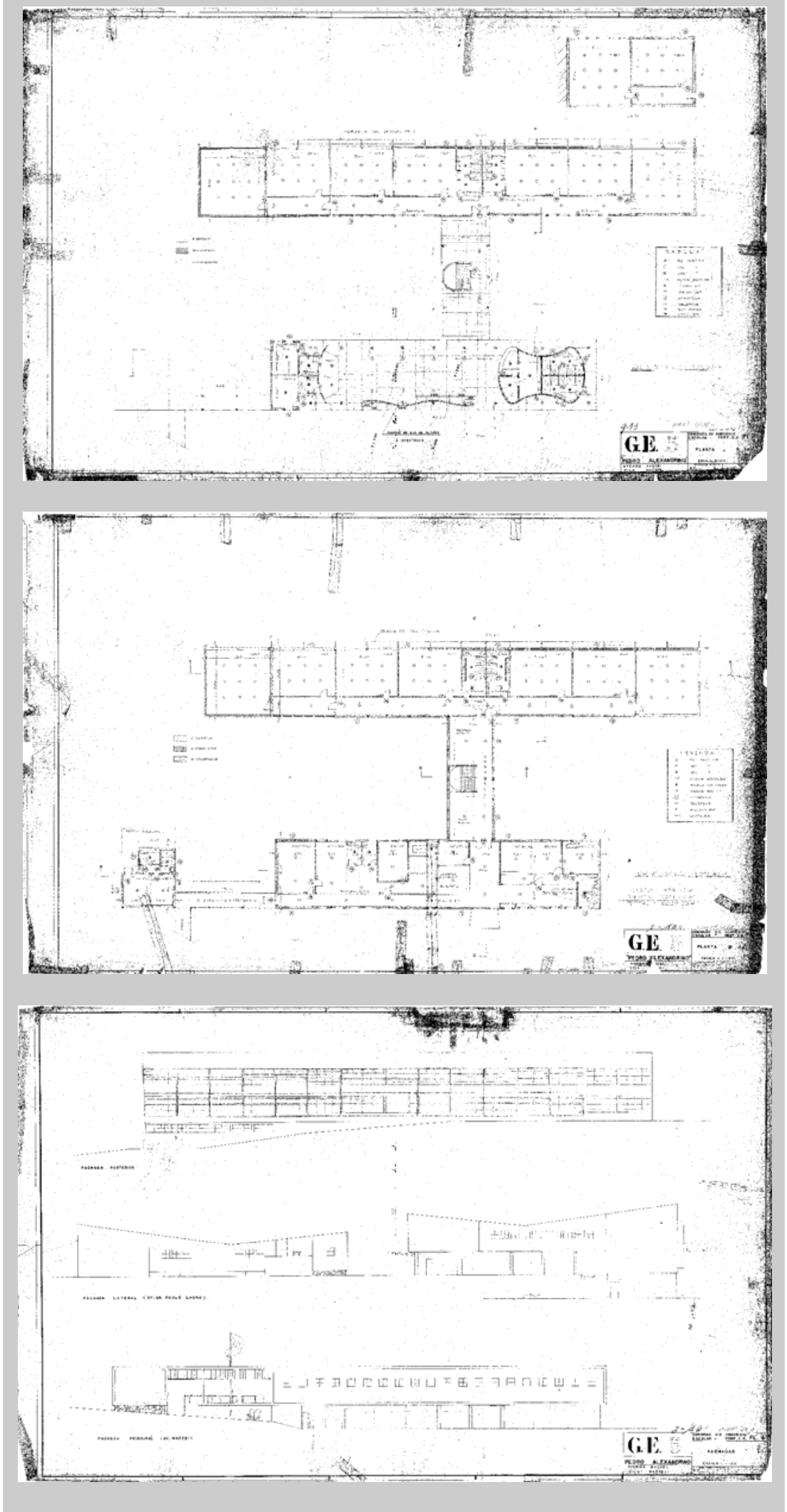

As plantas mostram um projeto completo com modificações datadas de 20 de dezembro de 1950. Aqui se revela outra prática que seria muito comum nos anos posteriores: para incluir modificações nos prédios já construídos pela própria $\mathrm{CE}$ os arquitetos utilizavam as mesmas pranchas do projeto original, apenas incluindo as novas informações, que neste caso são duas salas de aula. Outro aspecto que seria também recorrente é o uso do galpão como parte integrante de um dos blocos do edifício, ao contrário de outros casos em que o galpão de recreação é isolado, com cobertura exclusiva. 
Toledo Barbosa (G.E. 06)

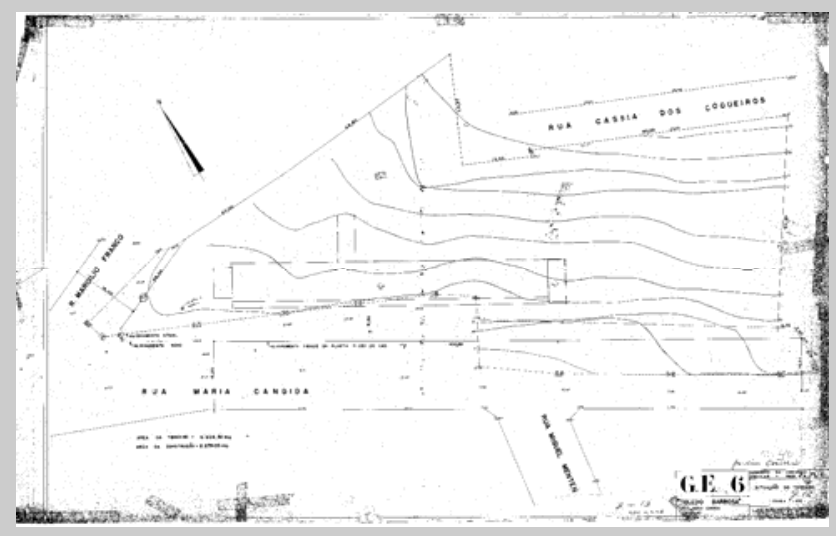

O terreno de dimensões generosas

era comum na época. A

desproporção do edifício em relação ao terreno não demonstrava relação com uma possível expansão da área construída simplesmente, pois a área disponível é suficiente para mais do que duplicar o tamanho da edificação original. A escala dos desenhos era, em geral de 1:100. Esta escola, cujo desenho está datado de 26 de dezembro de 1949, ainda possui o recreio coberto sob a edificação, e não em um espaço separado.

Pandiá Calógeras (G.E. 07)

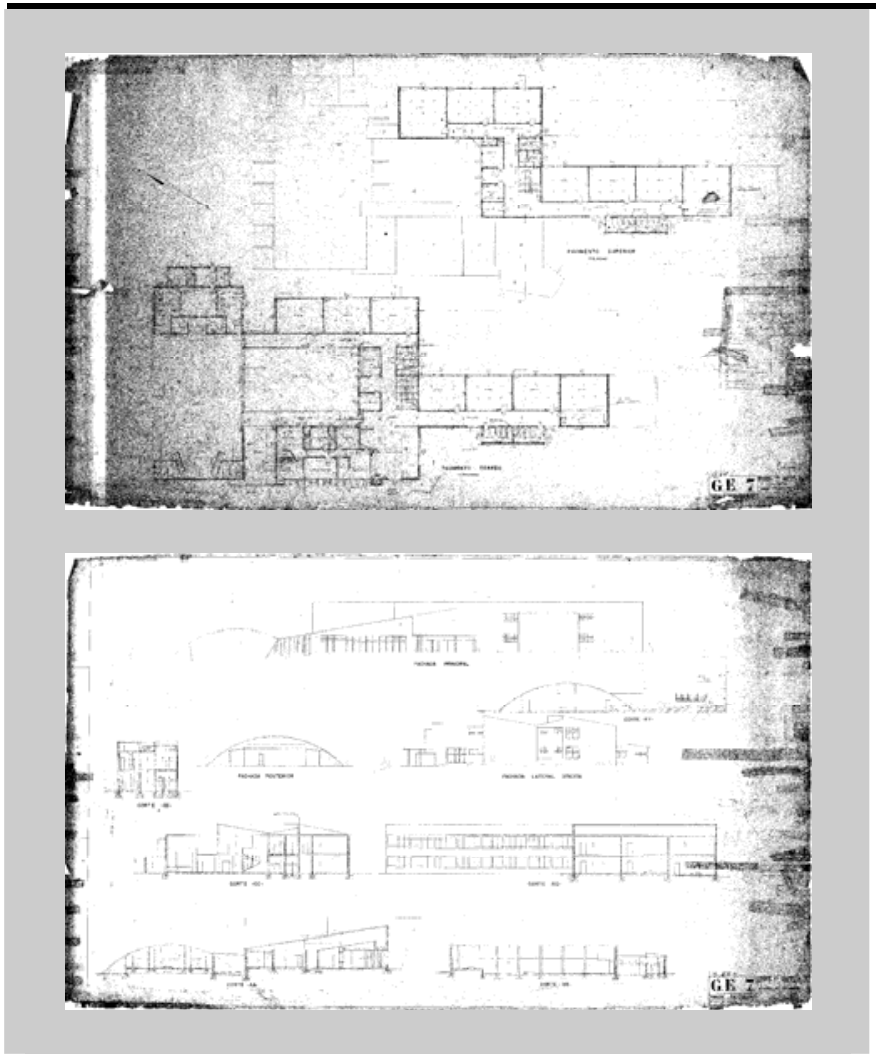

O projeto, que contém datas de 31 de maio e de 3 de junho de 1949, demonstra que a numeração dos grupos escolares não correspondia à data do projeto. $\mathrm{O}$ conjunto, de grandes proporções, mantém o alinhamento das salas de aula em um lado corredor de acesso, em função da insolação. Para este projeto já havia uma modificação datada de $18 \mathrm{de}$ fevereiro de 1950. 
Almirante Barroso (G.E. 08)
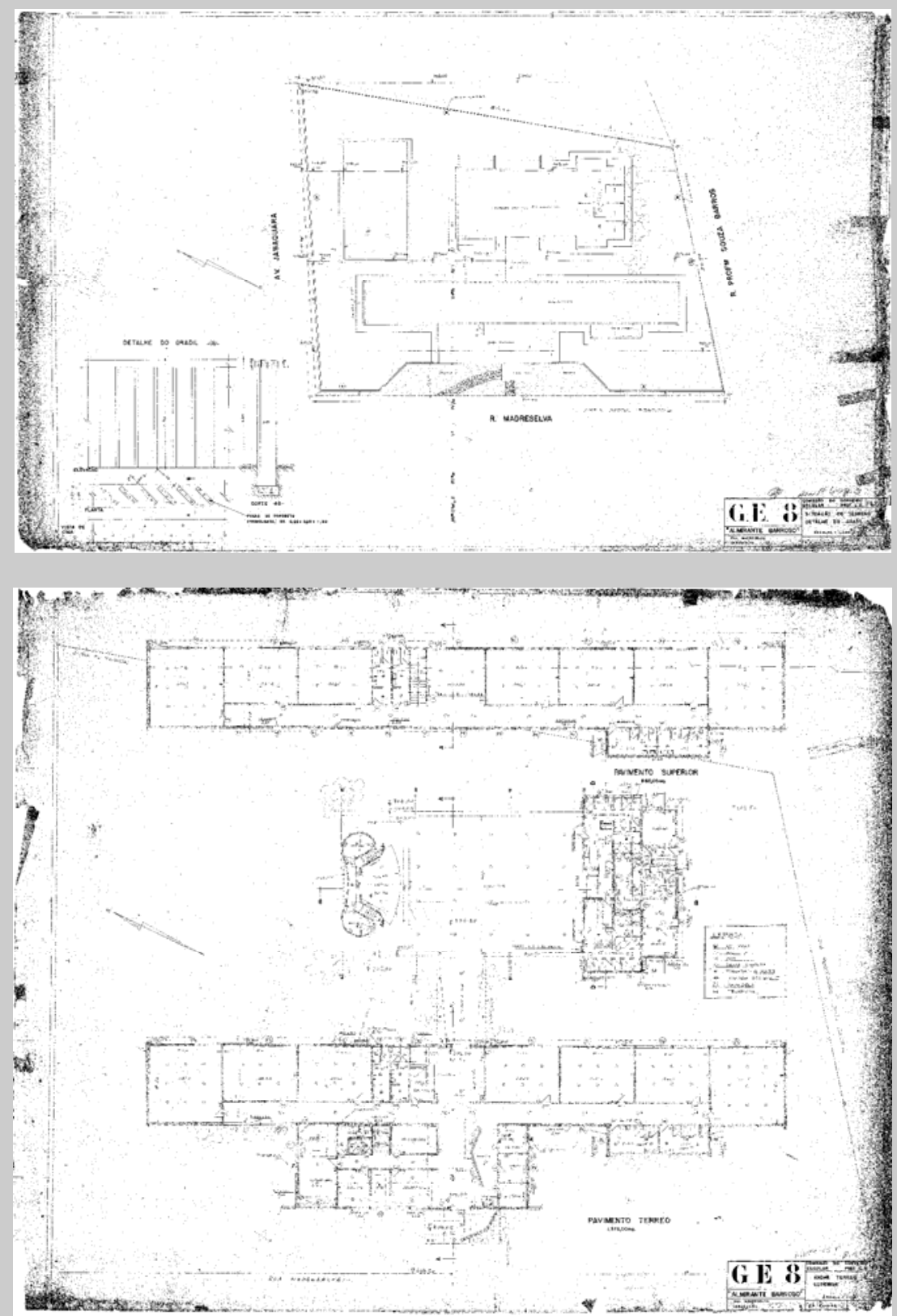

Datado de 24 de maio de 1949, possui uma característica peculiar, a de colocar detalhes construtivos de gradil em uma planta de situação. A prática de colocar detalhes menores em plantas com outra finalidade certamente se deve à economia de tempo e de folhas de desenho, não em termos de papel gasto, mas em quantidade de material a ser manipulado. É um dos projetos que possui terreno mais compatível com o tamanho do edifício: há menos área livre em relação à área construída. Essa escola inaugura o uso de janelas quadradas e com menor área de iluminação do que as que foram usadas na maioria das outras edificações escolares para iluminar os corredores de acesso às salas de aula. Também era denominado Vila Jabaquara. 
Vila Gustavo (G.E. 09)

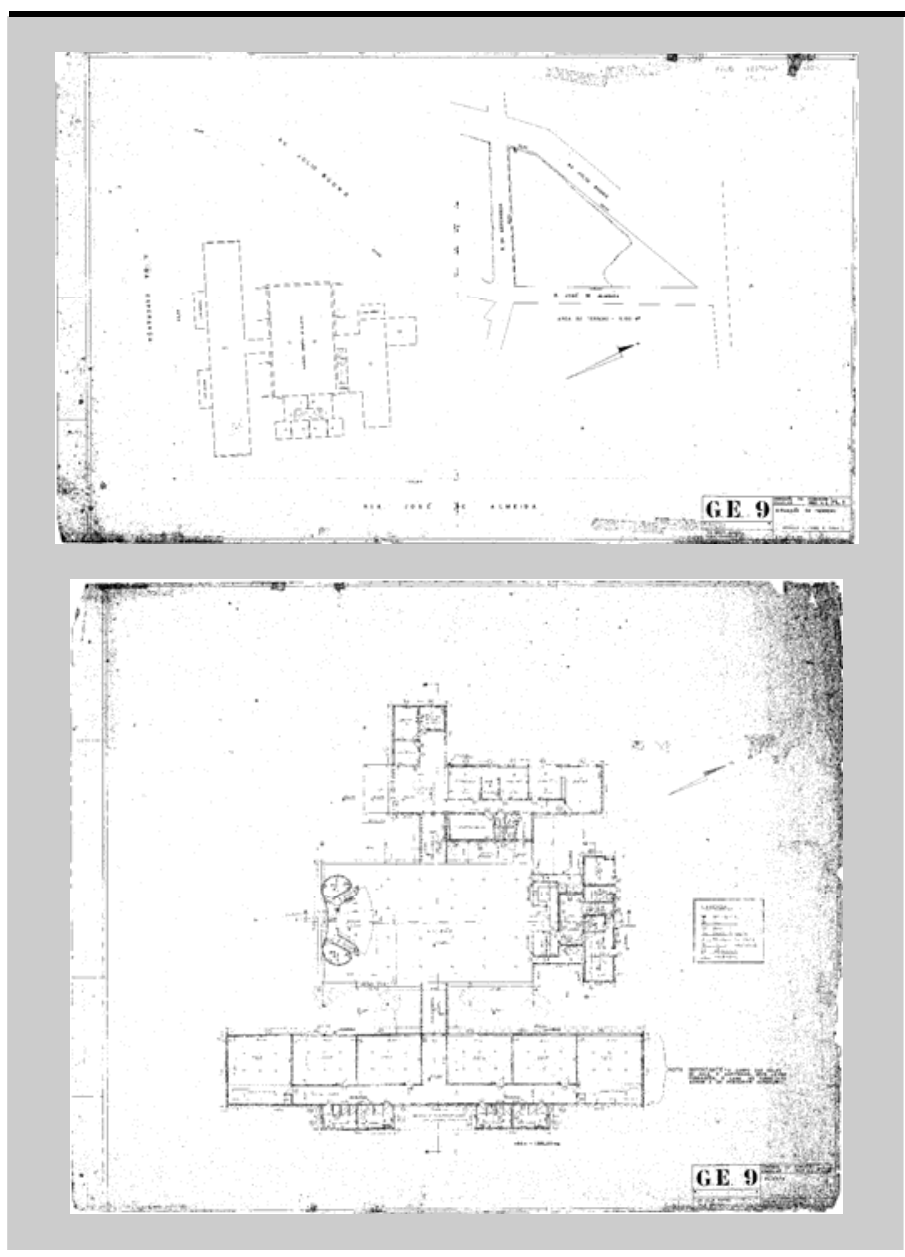

O projeto data de 3 de junho de 1949 e utiliza as mesmas formas do G.E. 08, porém com um arranjo diferente. Há um outro projeto com o mesmo nome e numeração. A setorização continua, mas os blocos, ainda que alinhados em torno de uma circulação horizontal cruzada, dispõem-se no terreno de maneira diferente. $\mathrm{O}$ telhado de duas águas em um trecho da edificação não era solução comum.

Vila Gustavo (G. E. 09)

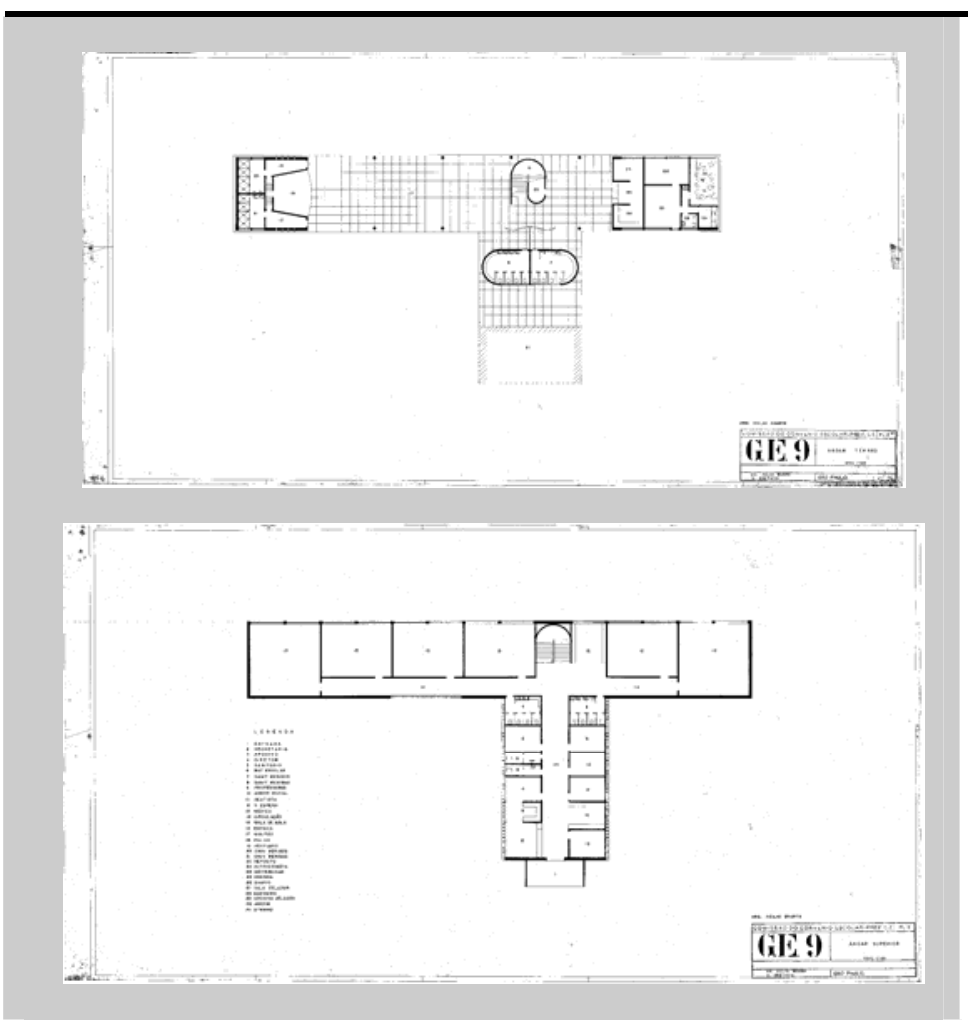

Este grupo escolar, também chamado de Vila Gustavo e com a mesma numeração do anterior (G.E. 09), também está com a indicação do mesmo endereço. Não é de forma alguma uma simples ampliação, mas sim uma escola nova completa, e segundo indicação em planta é da autoria do arquiteto Hélio Duarte, em uma das pouquíssimas vezes em que há uma identificação de autor de projeto. 
Romeu de Morais (G.E. 10)

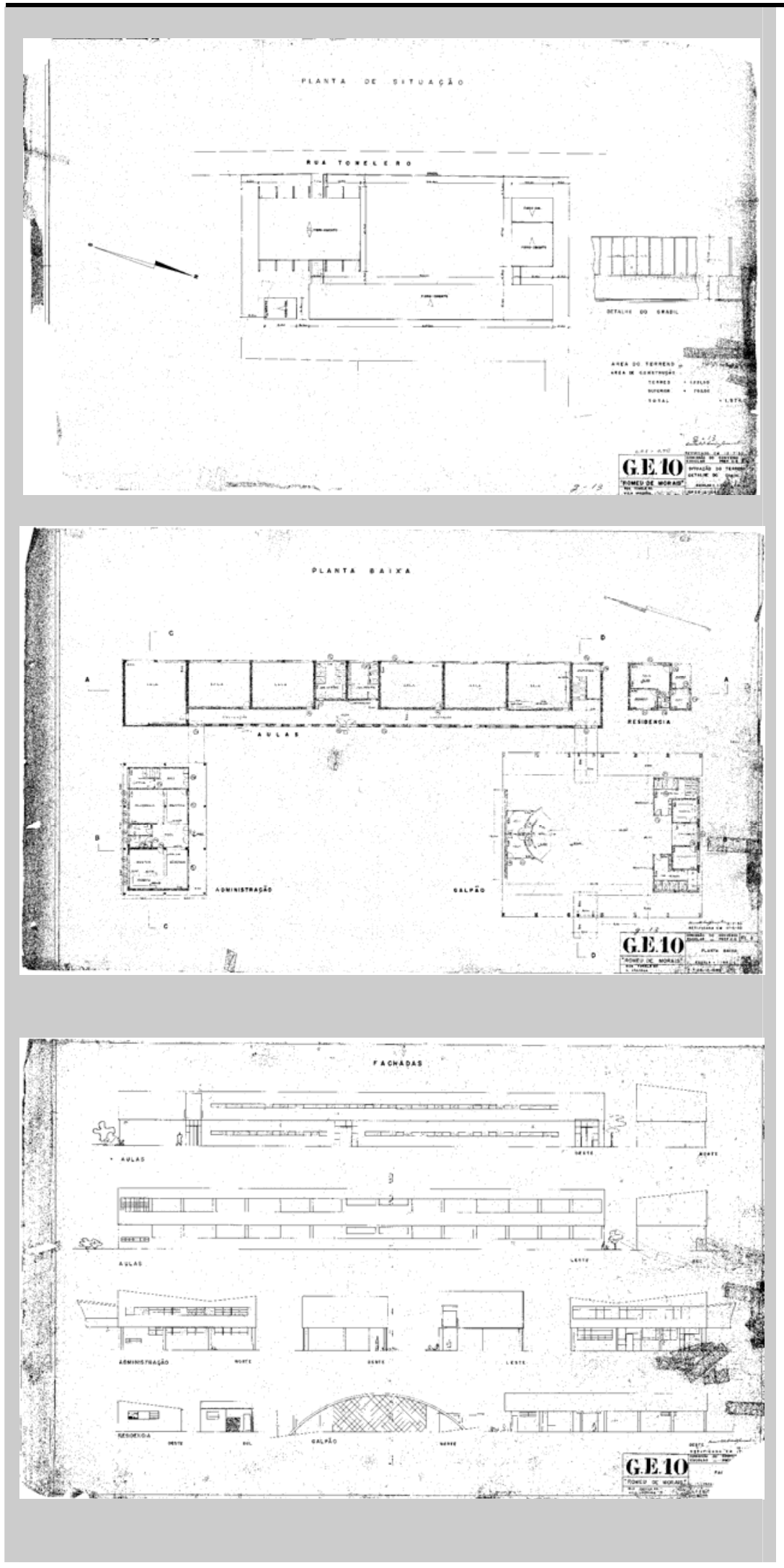

Datado de 28 de dezembro de 1949, é da autoria de Oswaldo Corrêa Gonçalves. Há duas datas de retificação: 17 de maio e 12 de julho de 1950. É uma das escolas que mais se encaixa na geometria do terreno, conseguindo delimitar os espaços livres, criando um grande espaço no centro do terreno, abraçado pelo conjunto de blocos. 
Vila Baruel (G.E. 11)

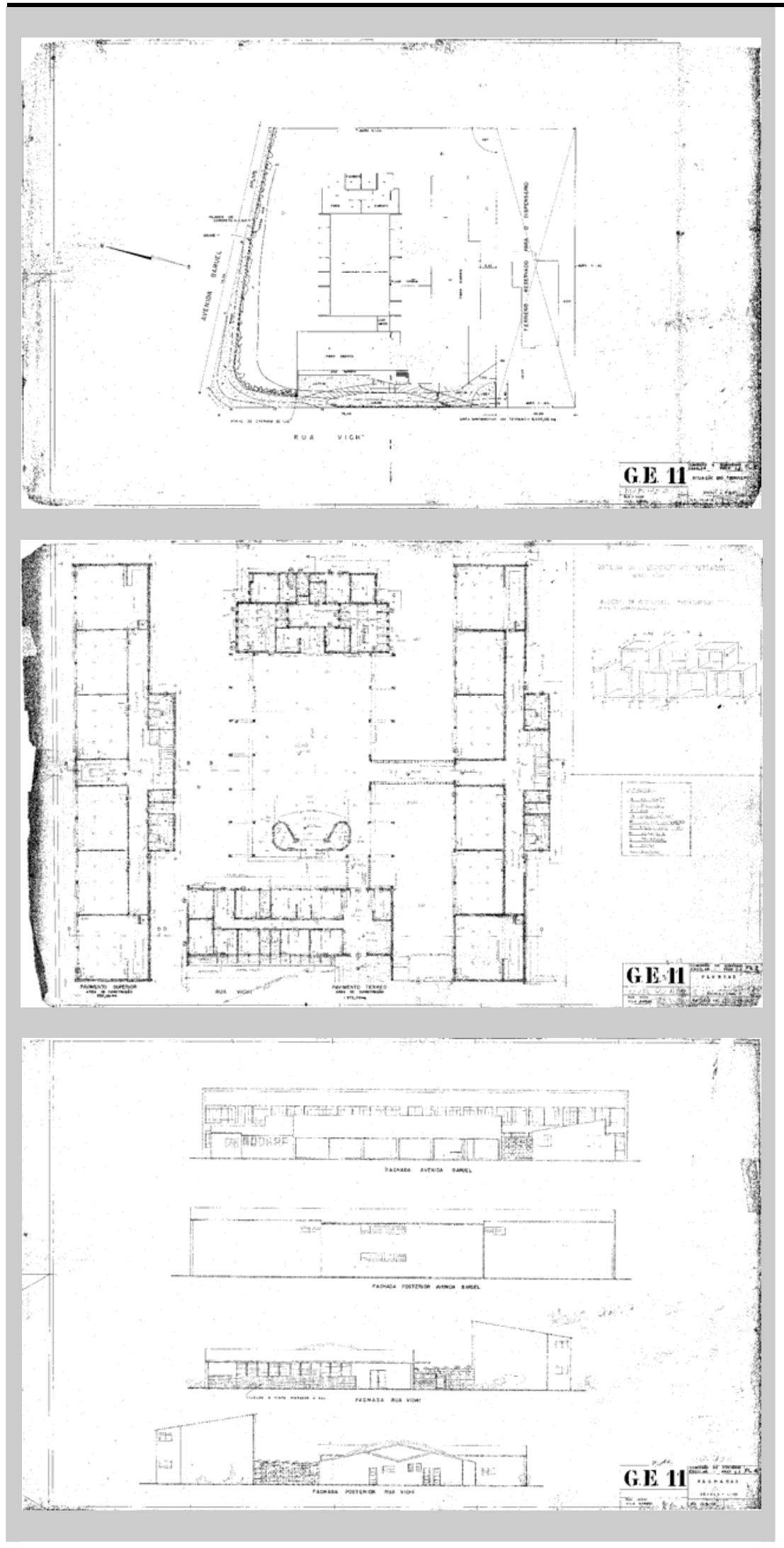

O projeto é datado de 13 de agosto de 1949 e possui uma enorme semelhança com o G.E. 09 e também, em menor intensidade, com o G.E. 08. No primeiro caso a semelhança pode ser devido à velocidade com que os projetos tinham de ser feitos. Há uma diferença na localização do setor administrativo em relação ao galpão. 
Vila Campo Grande (G.E. 12)
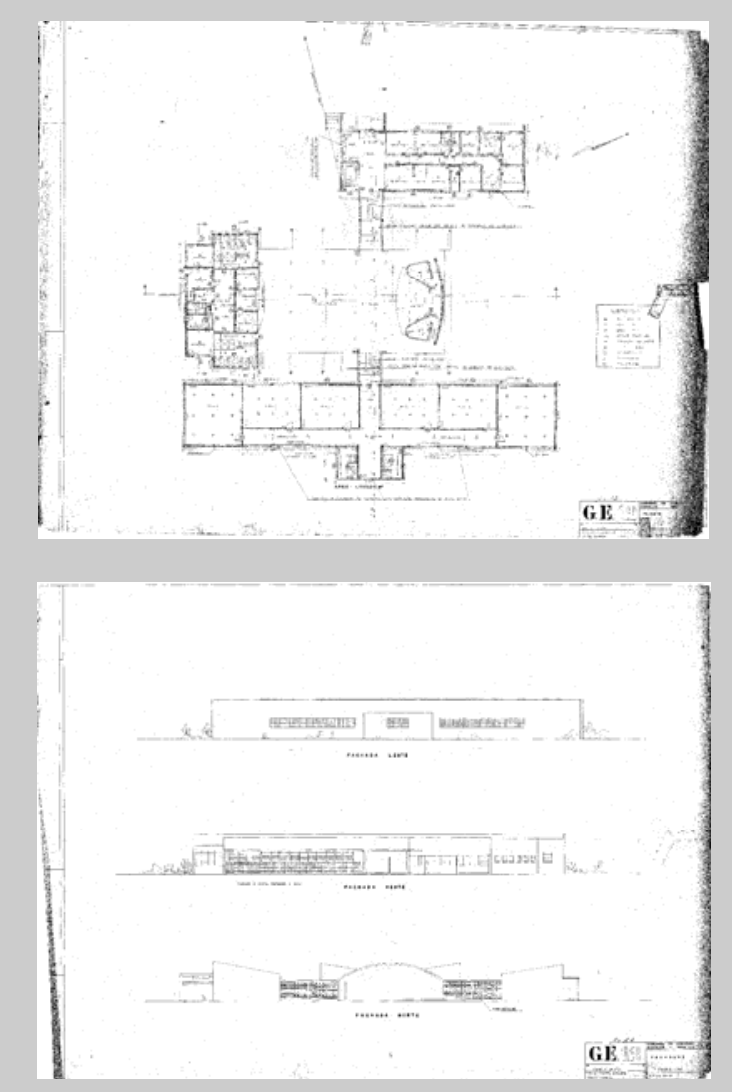

O projeto é de 15 de outubro de 1949. A diferença entre a forte simetria e a planta com seus volumes deslocados é um recurso refinado deste projeto e pouco usado em outras escolas. A composição aditiva por zoneamento funcional exige um grande controle espacial do projeto para se alcançar esse resultado.

Orville Derby (G.E. 13)

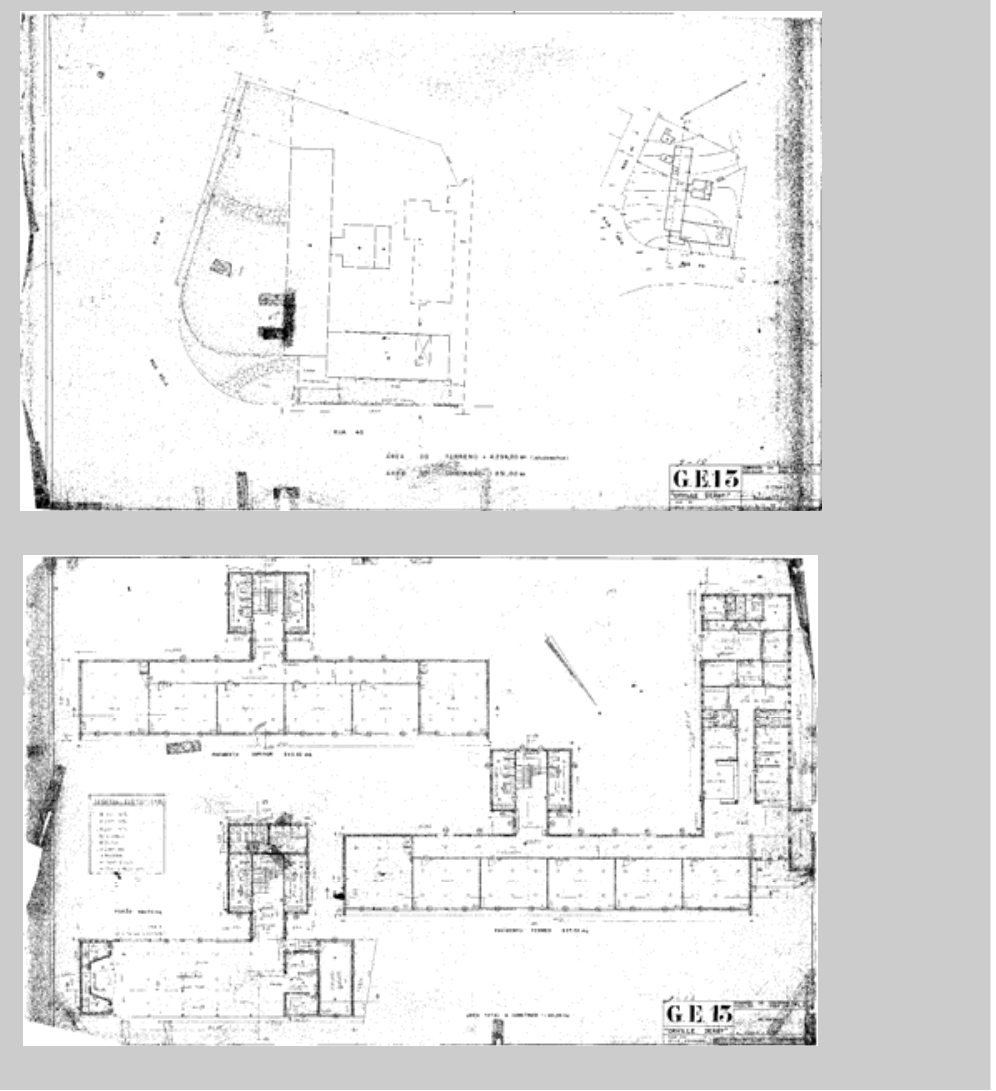

O projeto está datado de 9 de novembro de 1949. A diferença entre o tamanho do terreno e o do projeto é uma marca da época. $\mathrm{O}$ galpão permanece sob o volume destinado às salas de aula. 
Cezar Martinez (G.E. 14)

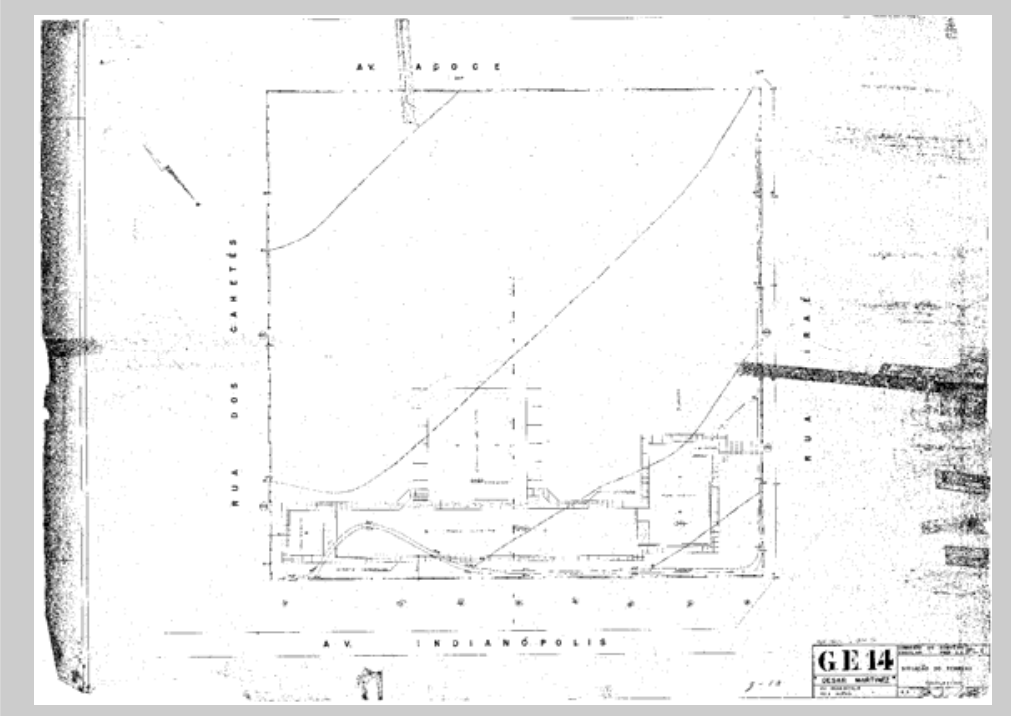

Não há data do projeto original,

apenas do modificativo, que é de 9

de dezembro de 1950. O edifício

se assemelha bastante a uma

indústria, bem como outras escolas

da época. $O$ projeto é exatamente

o mesmo que foi usado na Vila

Leopoldina (G. E. 01 - João M.

Boanova).
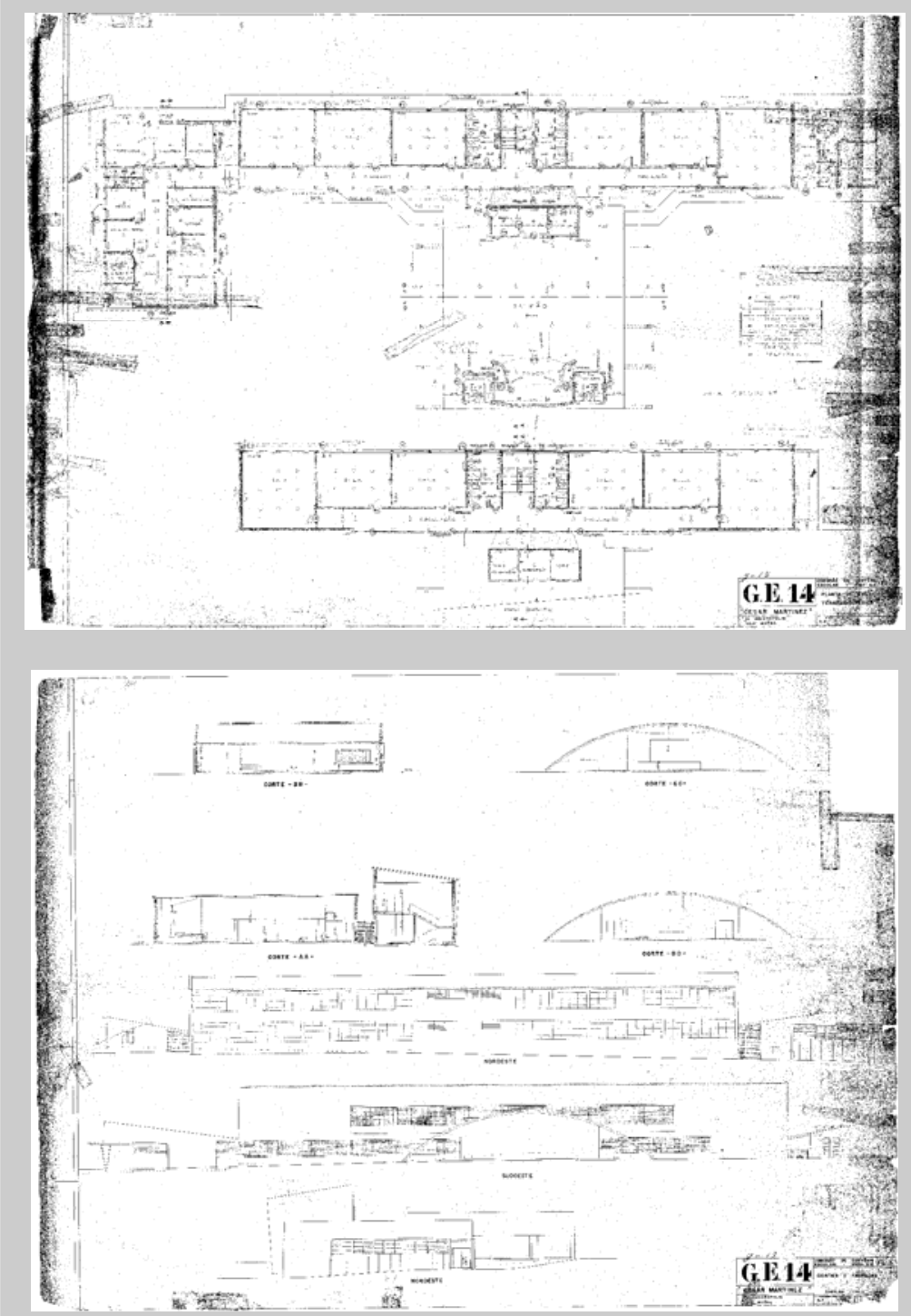
Reinaldo Ribeiro da Silva (G.E. 15)

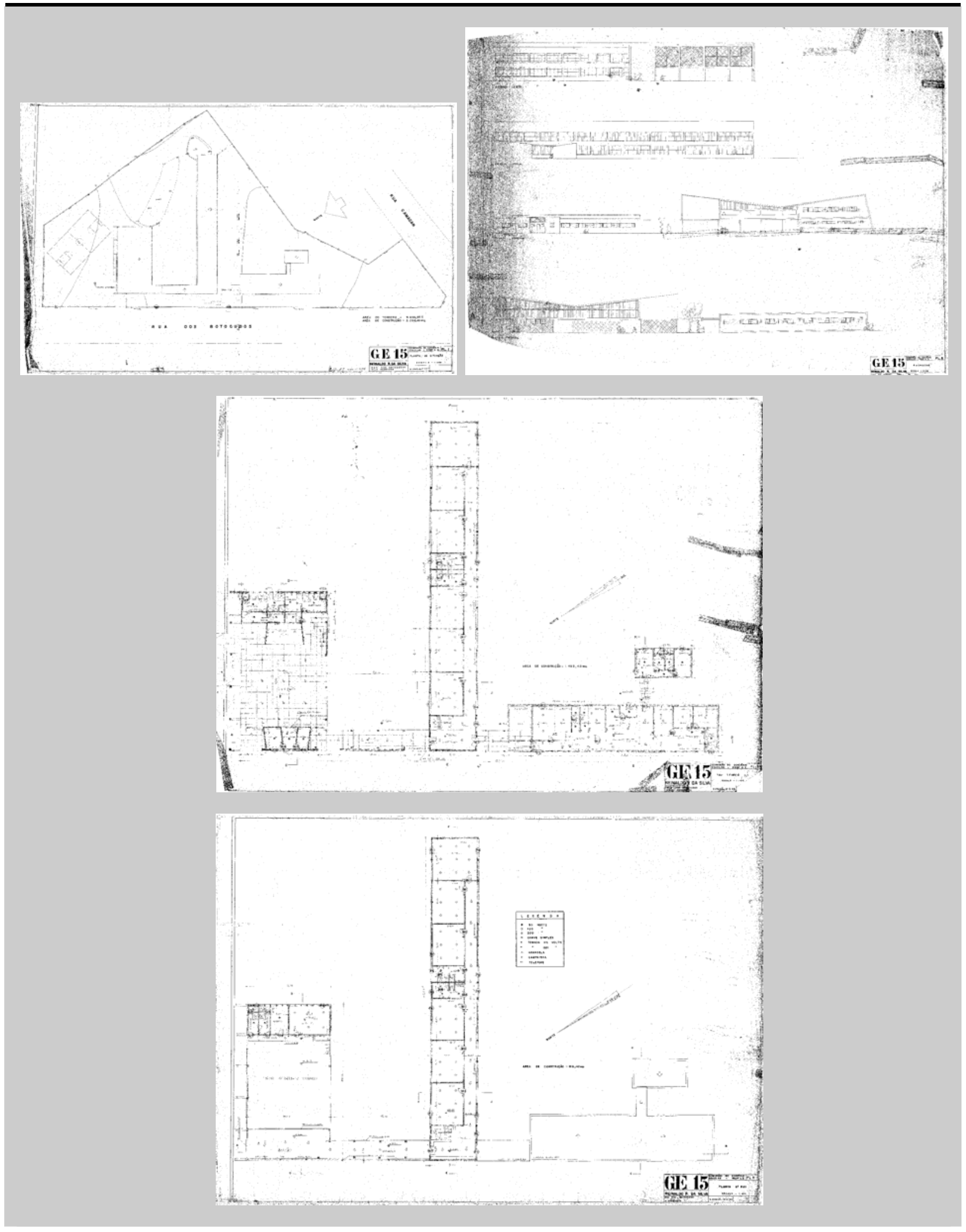

O projeto é datado de 13 de março de 1950. Prevalece ainda a solução de orientar as salas de aula em conjunto para a melhor orientação dentro do terreno, que neste caso, em função do posicionamento geral do edifício e da forma do terreno é a direção nordeste. 
Monsenhor Passalaqua (G.E. 16)
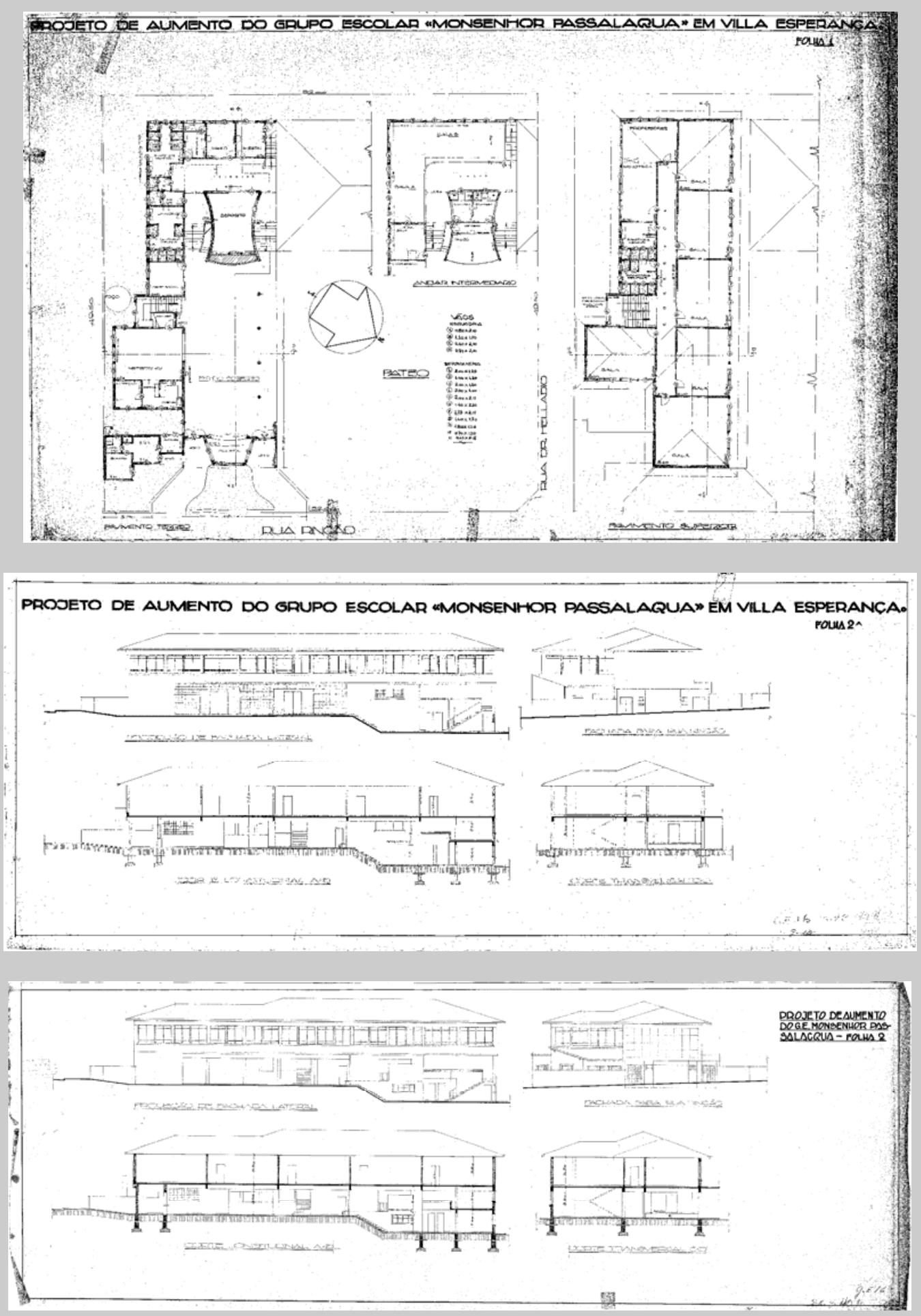

Não há indicação de data ou de autoria do projeto. Também não foi possível confirmar se a ampliação de que trata o desenho foi feito pelos arquitetos e engenheiros do Convênio Escolar. Essa possibilidade, apesar da ausência de indicações em planta, não pode ser descartada pois no Convênio Escolar já haviam sido feitas reformas em edifícios já existentes antes de 1948. 
Murtinho Nobre (G.E. 17)

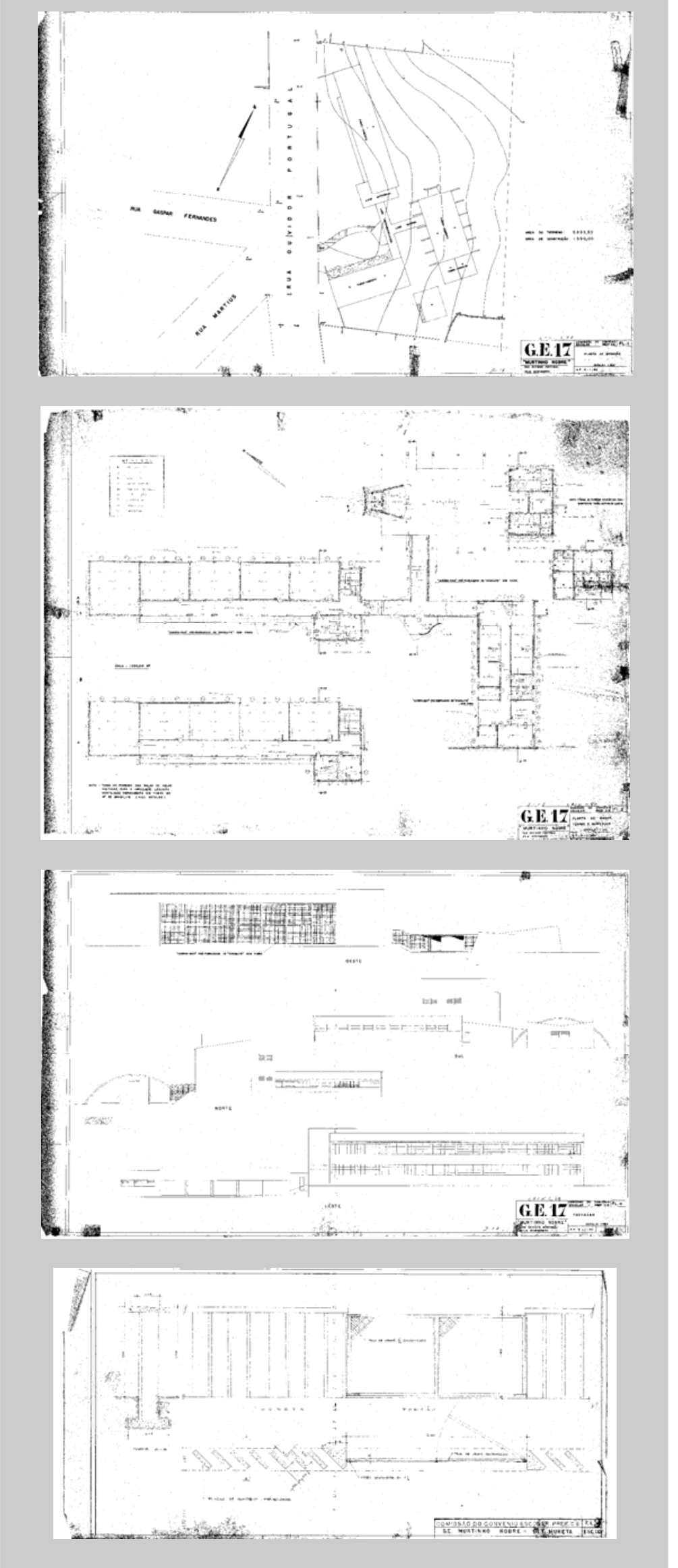

O projeto data de 5 de janeiro de 1950. As dimensões consideráveis dos terrenos e a horizontalidade nos projetos gera por vezes uma implantação com blocos dispersos unidos por circulações relativamente extensas, como é o caso deste grupo escolar. Há ainda a modificação do palco do galpão, datada de 4 de dezembro de 1950. Os quebra-sóis e os muros foram feitos de elementos pré-fabricados, de fibrocimento e concreto armado respectivamente. 
Visconde de Taunay (G.E. 18)

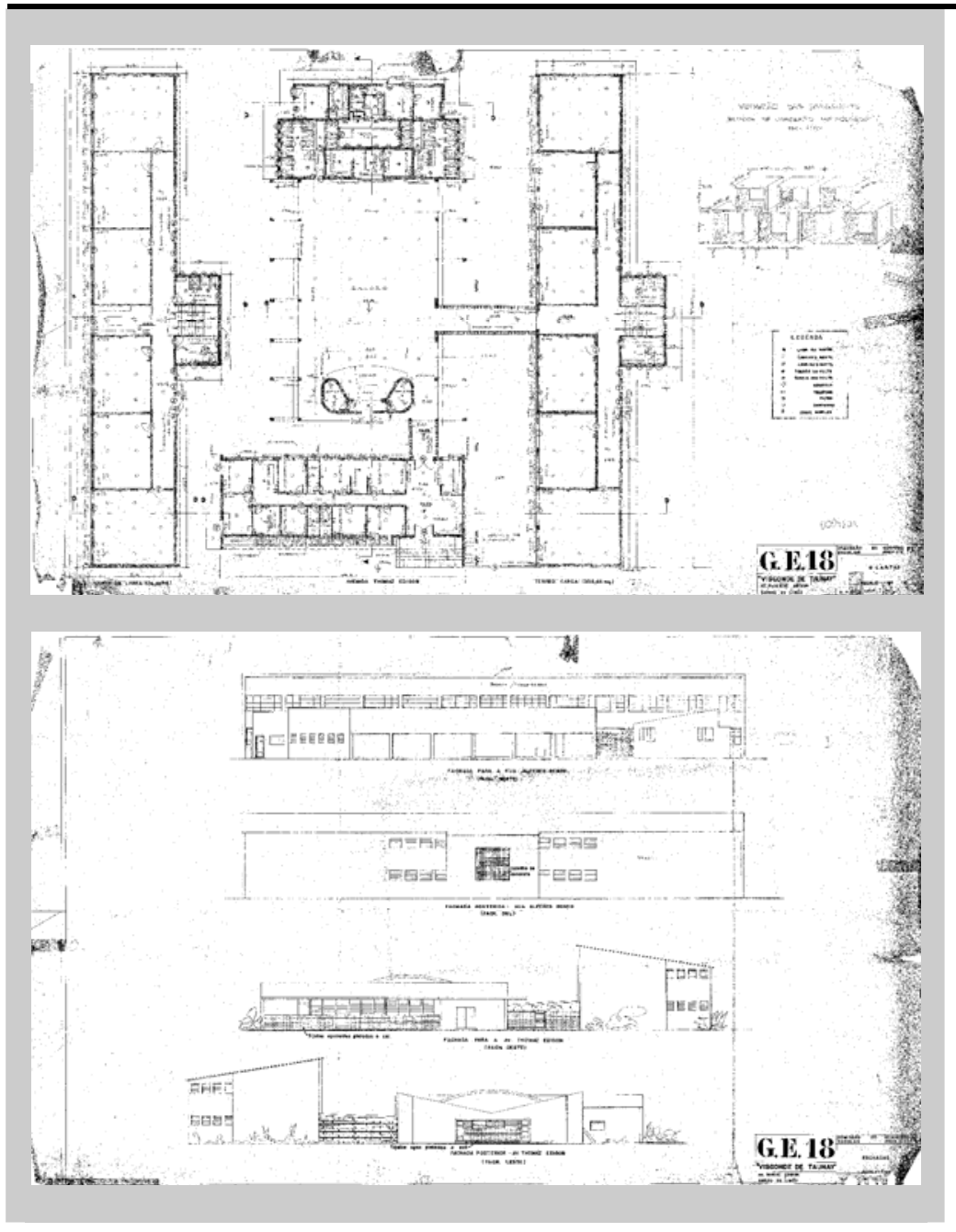

Datado de 17 de janeiro de 1950, é

o primeiro grupo escolar na seqüência adotada pelo Convênio que é um projeto idêntico a outro com numeração anterior. Neste caso o projeto é o G.E. 09, que foi inteiramente reproduzido nesta escola. O projeto G.E. 12 utiliza a mesma disposição interna nos setores, porém o arranjo dos blocos é um pouco diferente. Isso revela que havia diferentes níveis de reprodução de soluções de projeto para projeto.

Fonte: Arquivo EDIF-PMSP

\section{Erasmo Braga (G.E. 19)}

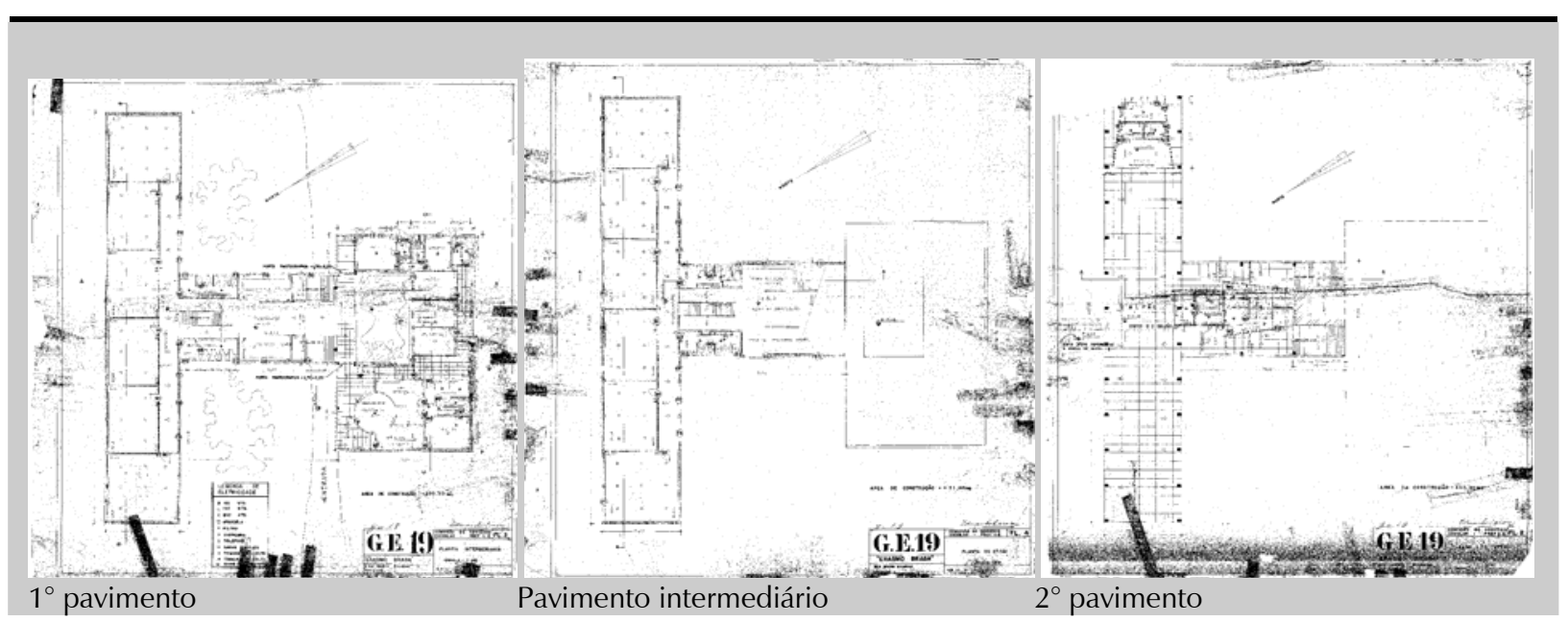

O projeto, de 14 de outubro de 1950 (a planta indica que é a data do modificativo), do arquiteto Eduardo Corona, é o primeiro na seqüência da CE com mais de dois pavimentos. A grande maioria das escolas construídas até esta data tem no máximo dois pavimentos no total, excetuando-se algumas situações em que, devido ao aproveitamento de desníveis existentes nos terrenos, são feitos em alguns trechos da escola três pavimentos. 
Visconde de Inhaúma (G.E. 20)

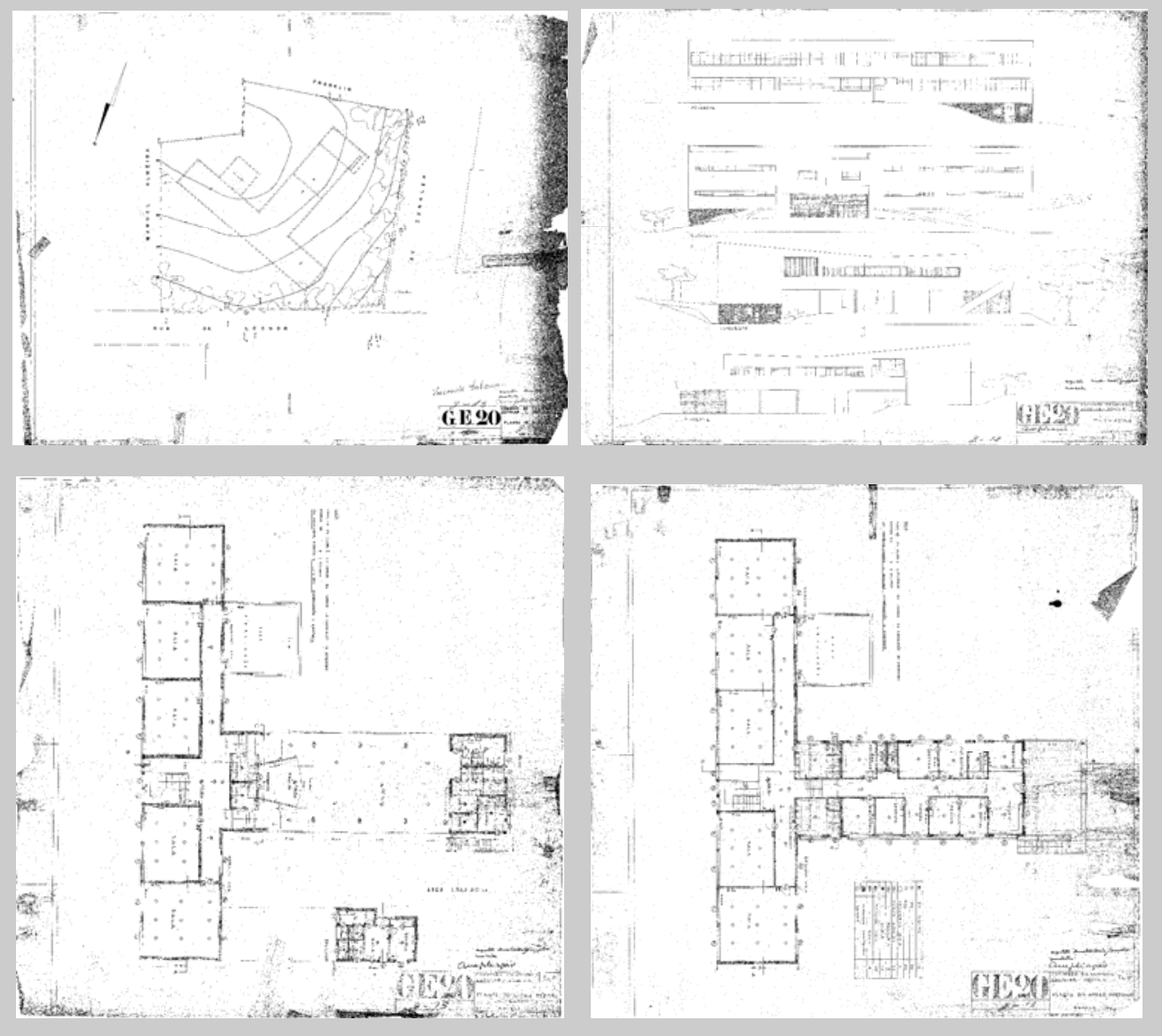

O projeto é de Oswaldo Corrêa Gonçalves (24 de fevereiro de 1950). Mais uma vez utilizam-se os próprios desenhos originais para neles acrescentar-se as ampliações, economizando bastante tempo na fatura dos desenhos. A segunda ampliação, datada de 10 de dezembro de 1953, é da autoria de Juvenal Waetge Junior.

Pedro Taques (G.E. 21)

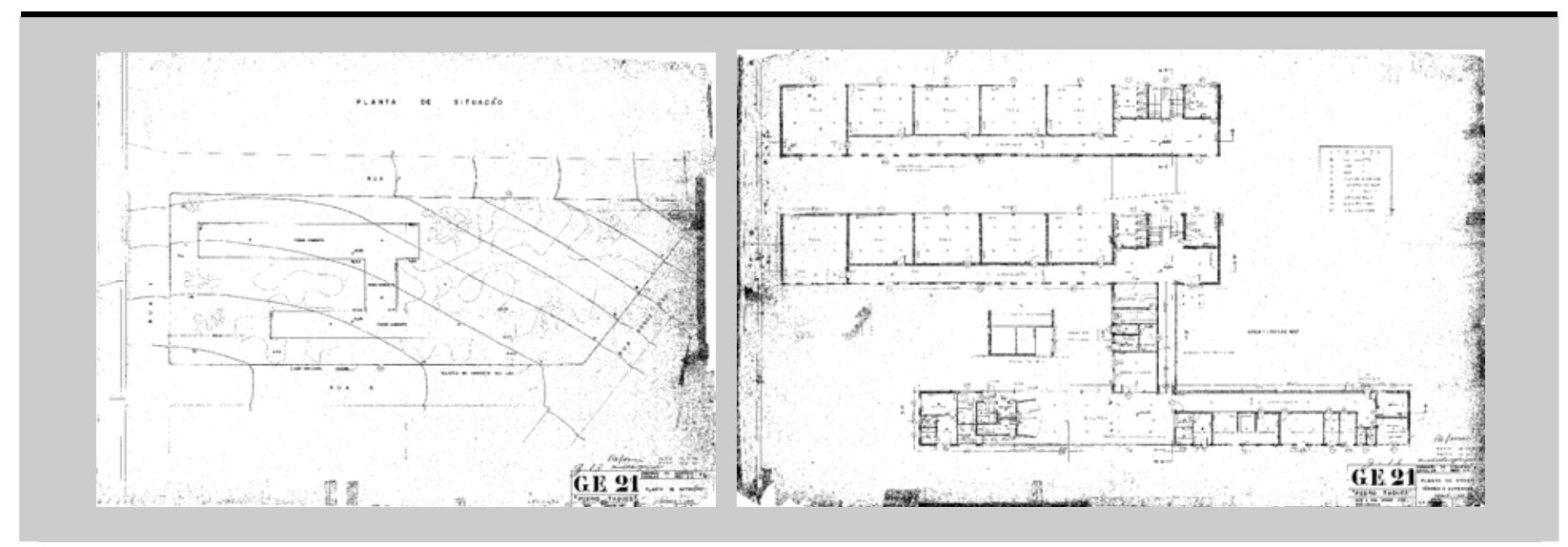

Datado de 22 de 1950, de autoria de Oswaldo Corrêa Gonçalves. Novamente não é possível confirmar se Gonçalves foi o autor do projeto, das retificações ou de ambos. Esta escola ainda utiliza o recreio coberto dentro do conjunto da edificação principal. Note-se novamente a desproporção entre o terreno e o tamanho do edifício. 
Barão Homem de Mello (G.E. 22)

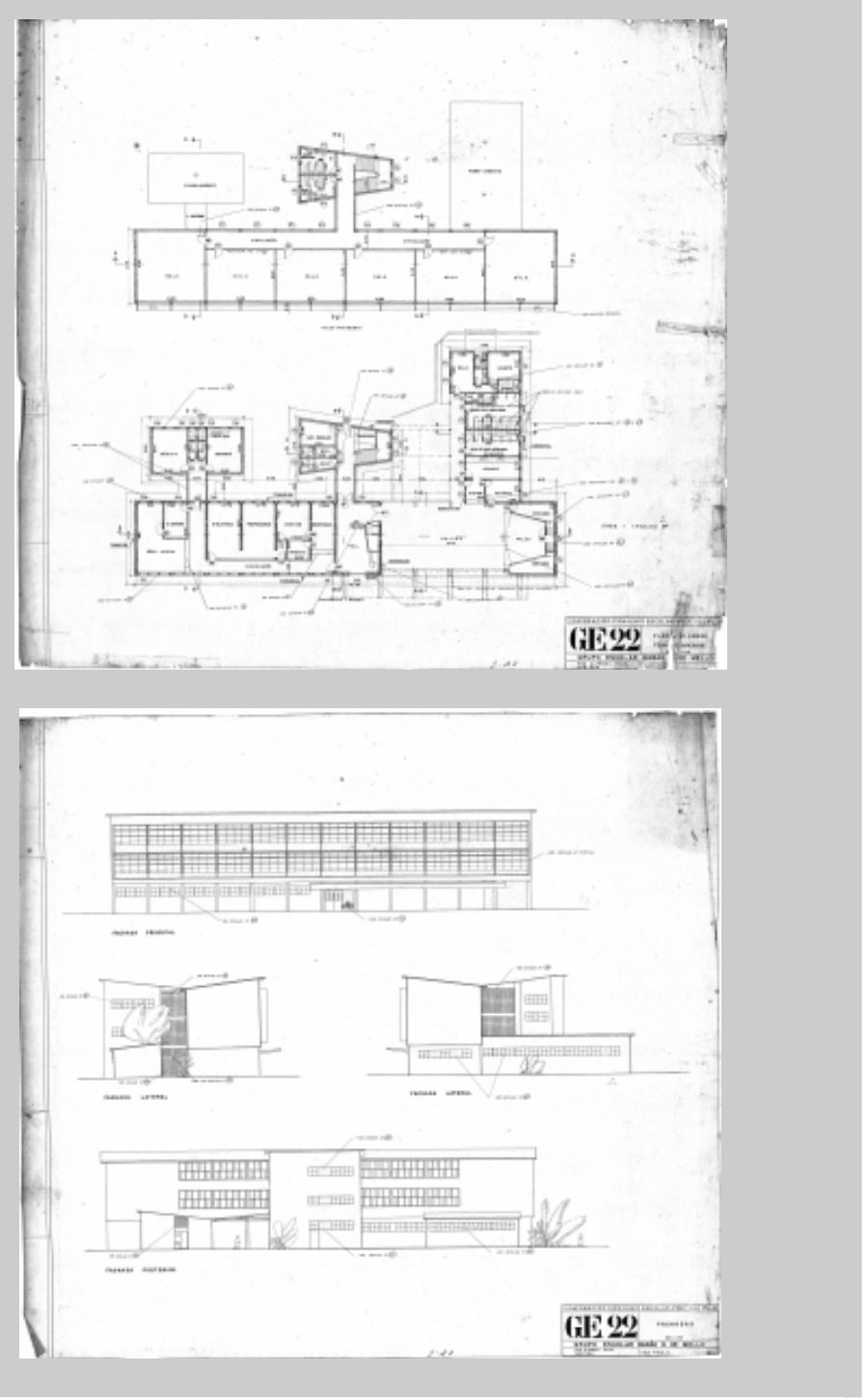

Apesar da ausência de uma data nas folhas de projeto foi possível verificar que o levantamento topográfico foi feito em $15 \mathrm{de}$ setembro de 1947, pelo Departamento de Obras da PMSP. Chama a atenção o fato de que o levantamento foi feito especificamente para a construção desta escola, antes mesmo da Comissão do Convênio Escolar ter sido estabelecida, o que indica que já havia diretrizes de escolha de terreno estabelecidas antes mesmo dos arquitetos e engenheiros da Comissão terem começado a trabalhar.

Fonte: Arquivo EDIF-PMSP 
Carlos Escobar (G.E. 23)

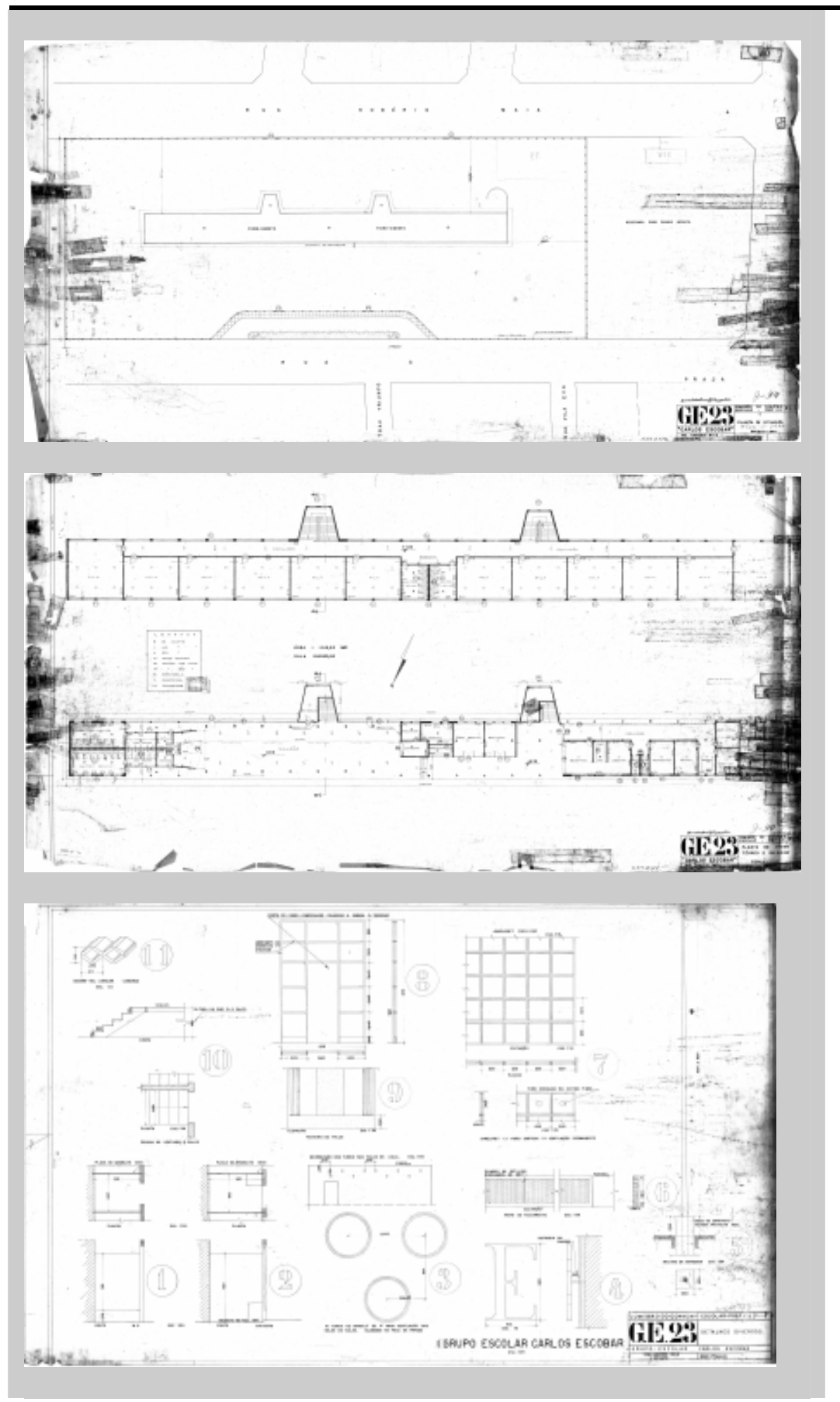

Datado de 27 de abril de 1950, é da autoria de Oswaldo Corrêa Gonçalves e há uma indicação de retificação, datada de 24 de outubro de 1950. A folha contendo detalhes tornou-se um modelo reproduzido em outros projetos. 
Alfredo Bresser (G.E. 24)

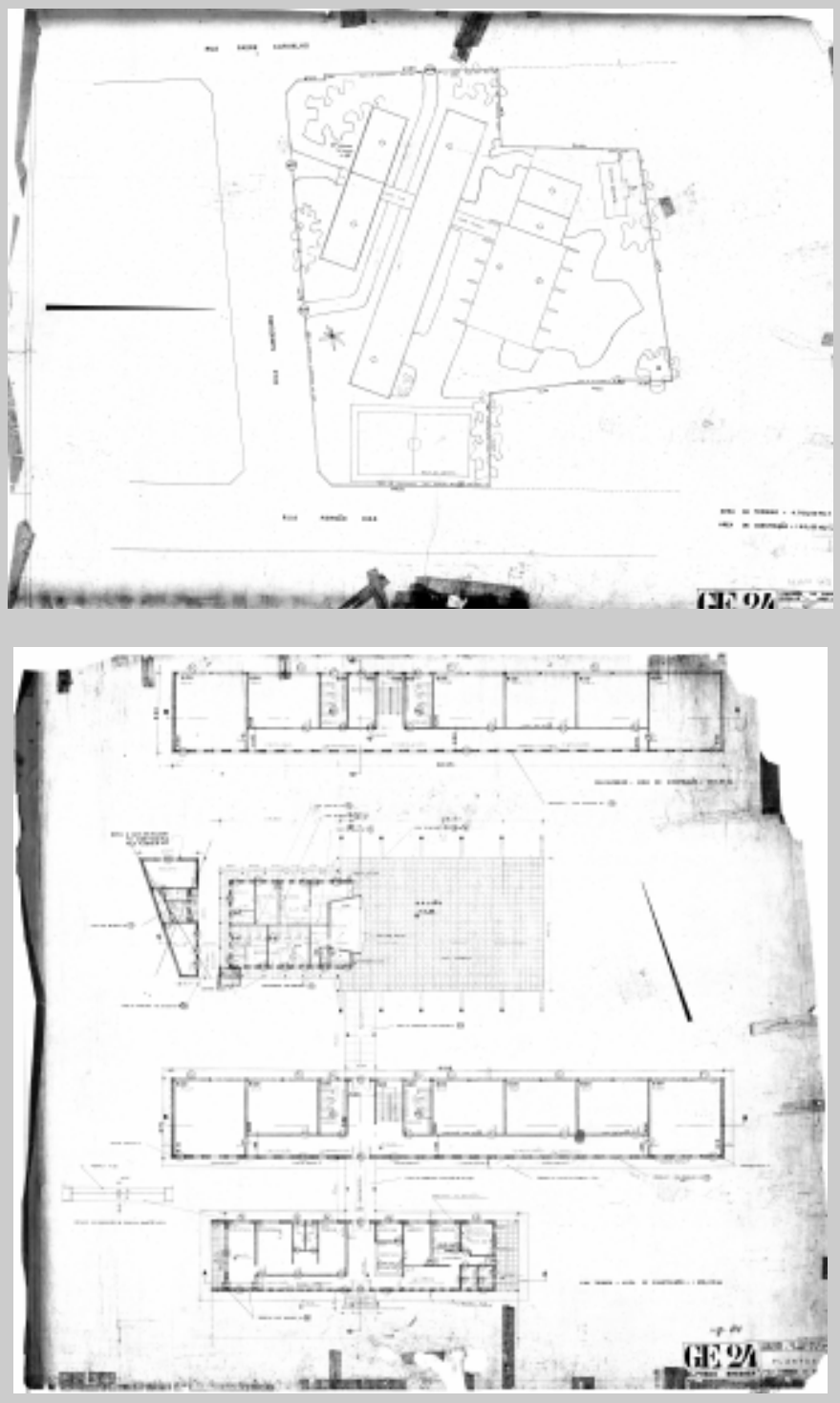

Reformas eram muito comuns: nesta escola foi feita uma cujo projeto está datado de 30 de janeiro de 1954, para acréscimo de instalações hidráulicas. Os detalhes revelam também uma solução até certo ponto questionável: as salas de aula tinham uma ventilação permanente na parte superior de uma das suas paredes. Em uma região que possui uma amplitude térmica elevada deveria sempre haver ventilação controlada. Uma justificativa poderia ser uma redução de custos com esquadrias. Esta escola hoje se encontra bastante deteriorada e com modificações que descaracterizam totalmente $\mathrm{o}$ conjunto. 
Canuto do Val (G.E. 25)

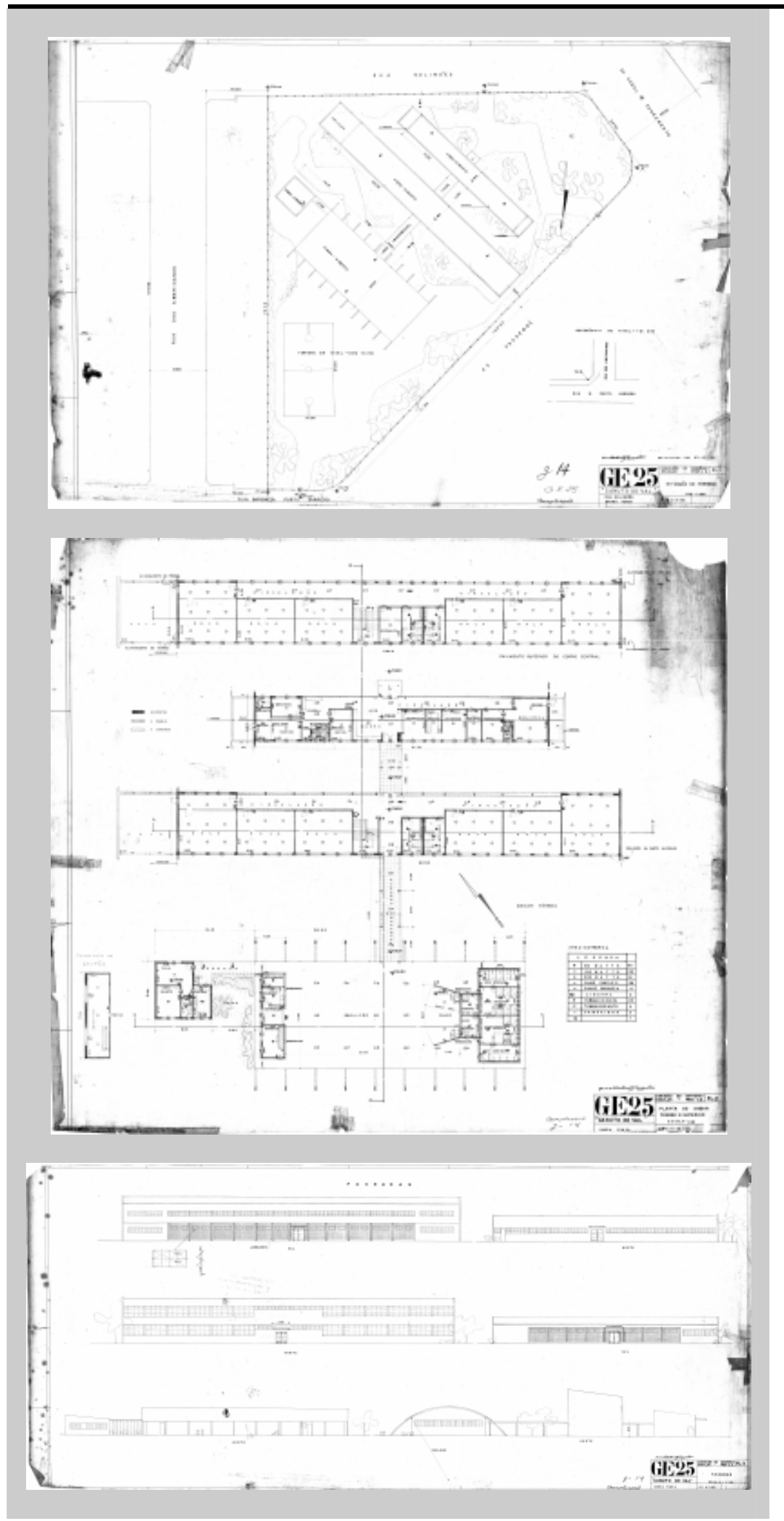

O grupo escolar Canuto do Val é de Oswaldo Corrêa Gonçalves. Ao que parece neste projeto os detalhes de esquadrias não seguiram os desenhos que estavam sendo utilizados. $\mathrm{O}$ sistema é o mesmo, porém a definição de áreas móveis e fixas, e as proporções das aberturas são diferentes, revelando certa autonomia do arquiteto ou uma mudança de direção da execução dos edifícios. A solução para a arquitetura do edifício é bastante semelhante à do grupo escolar Alfredo Bresser (G.E. 24), mas há algumas diferenças na organização interna dos grupos funcionais. 
Joaquim Nabuco (G.E. 26)

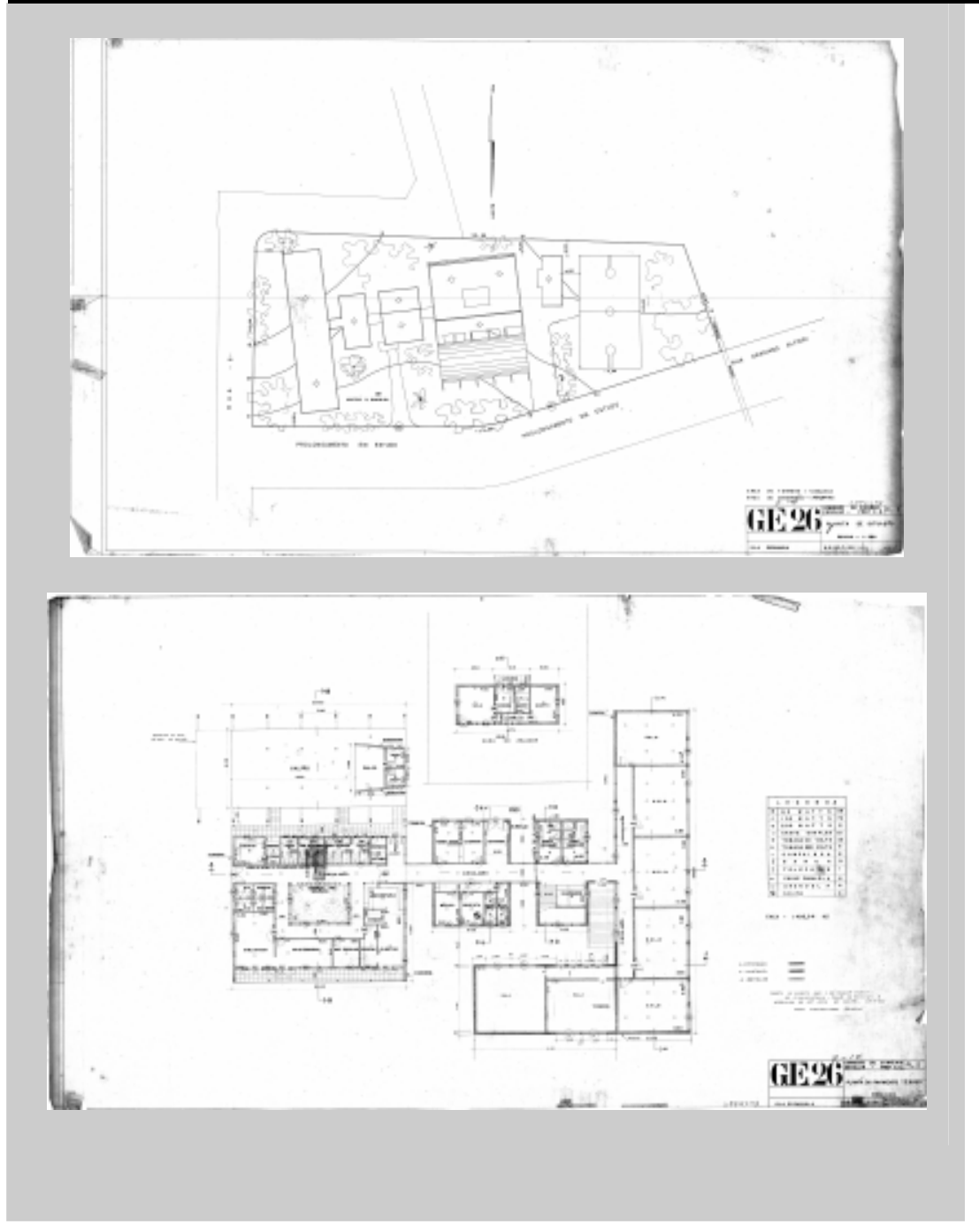

O projeto é de 27 de maio de 1950, com modificação em 14 de novembro de 1950. A escola é simétrica em torno de uma circulação que une todos os blocos, e que é uma marca das escolas desta seqüência. Há ainda um detalhe que era bastante utilizado nos projetos, e que em muito se assemelha aos muxarabis exaltados pelas análises dos arquitetos e que é mostrado na planta mostrada por último. Há um acréscimo importante de quatro salas de aula, sala de reunião e aumento na área do galpão em 15 de setembro de 1955. Essa intervenção modificou bastante a volumetria inicial do edifício, sendo da autoria de Rubens F. Azevedo. 
Pedro Voss (G.E. 27)

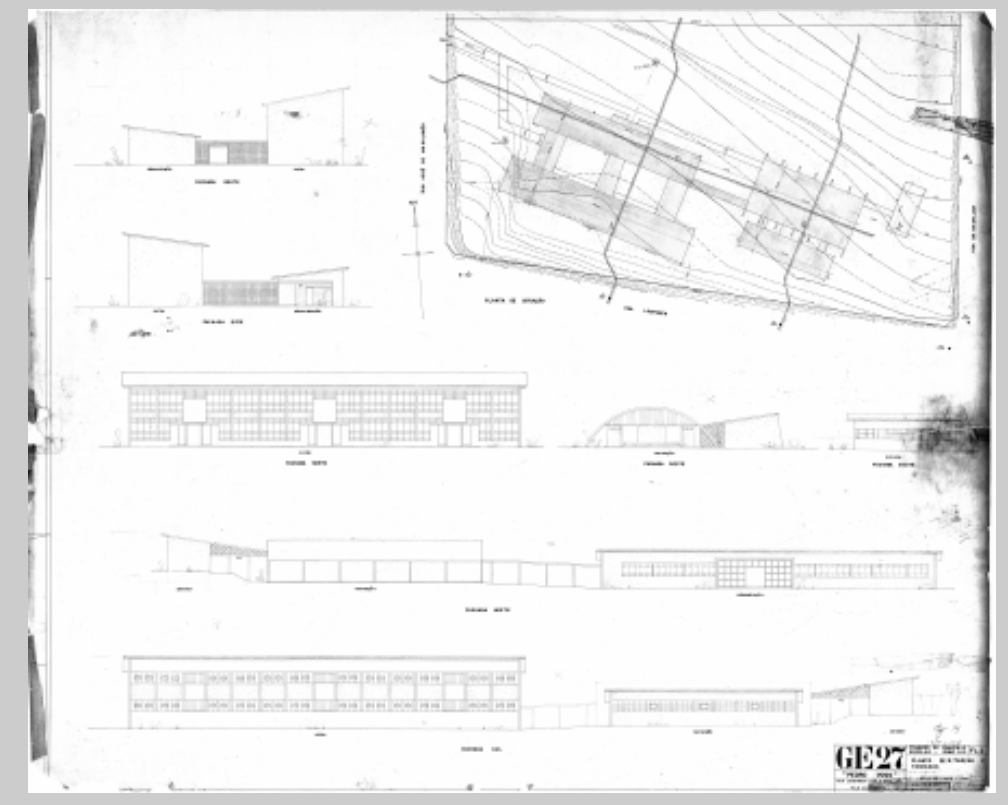

Datado de 14 de agosto de 1950, é um ds projetos mais simples, apesar do seu tamanho considerável, entre as escolas consultadas.

Bernardo Rodrigues Nogueira (G.E. 28)

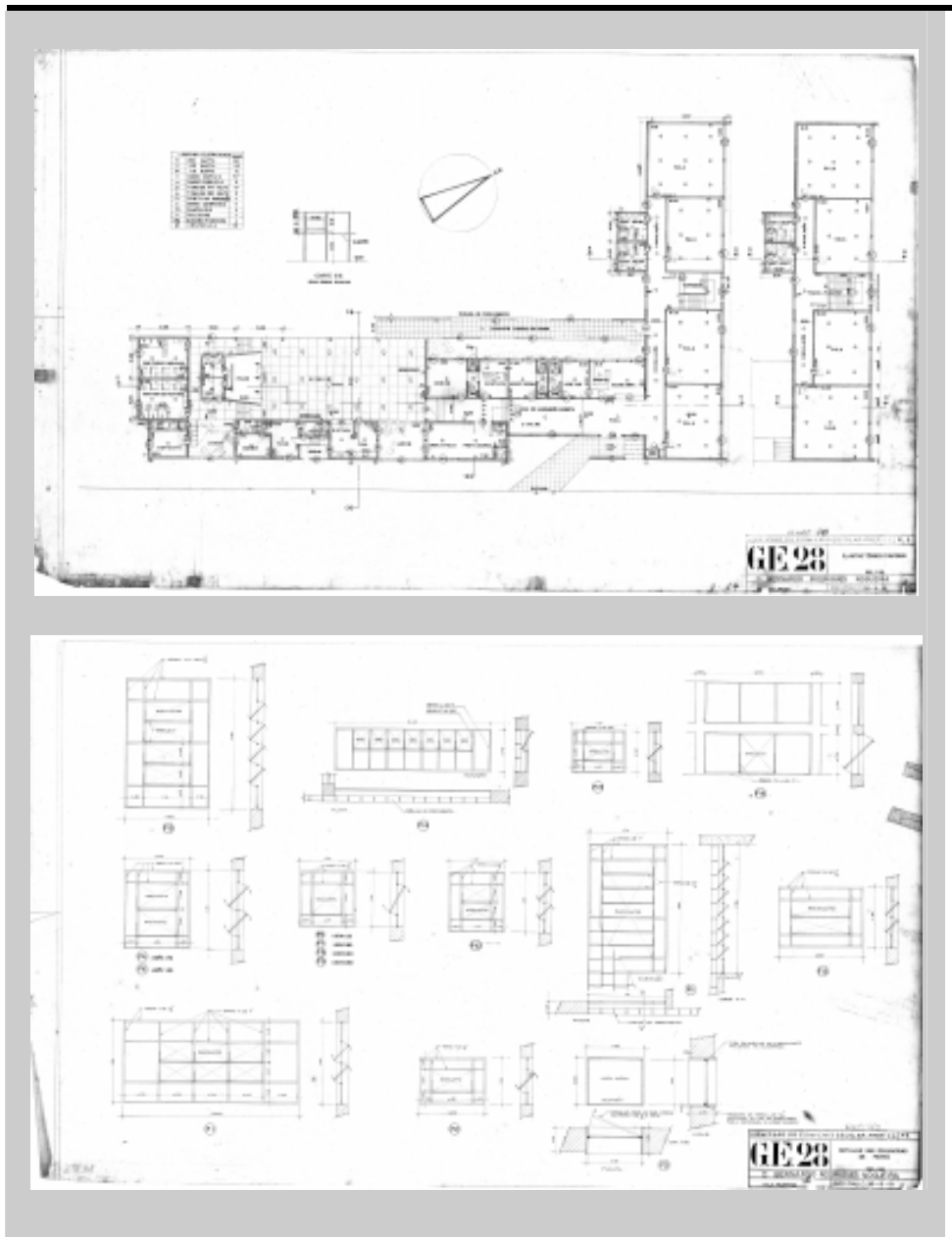

Datado de 30 de maio e de 14 de novembro de 1951. De uma maneira geral é possível afirmar que não havia uma sistematização clara quanto ao desenho das esquadrias. Ainda que o sistema de vidros basculantes e fixos, feitos com os perfis metálicos disponíveis no mercado fossem os mesmo, bem como a finalidade das aberturas nos edifícios, o desenho das esquadrias é heterogêneo. Isso é o suficiente para afirmarmos que certamente havia uma liberdade muito grande para os arquitetos definirem esse desenho. Em um ambiente em que a velocidade de construção era muito importante essa passa a ser uma forma de trabalho ambígua. 
Vila Nova Cachoeirinha (G.E. 29)

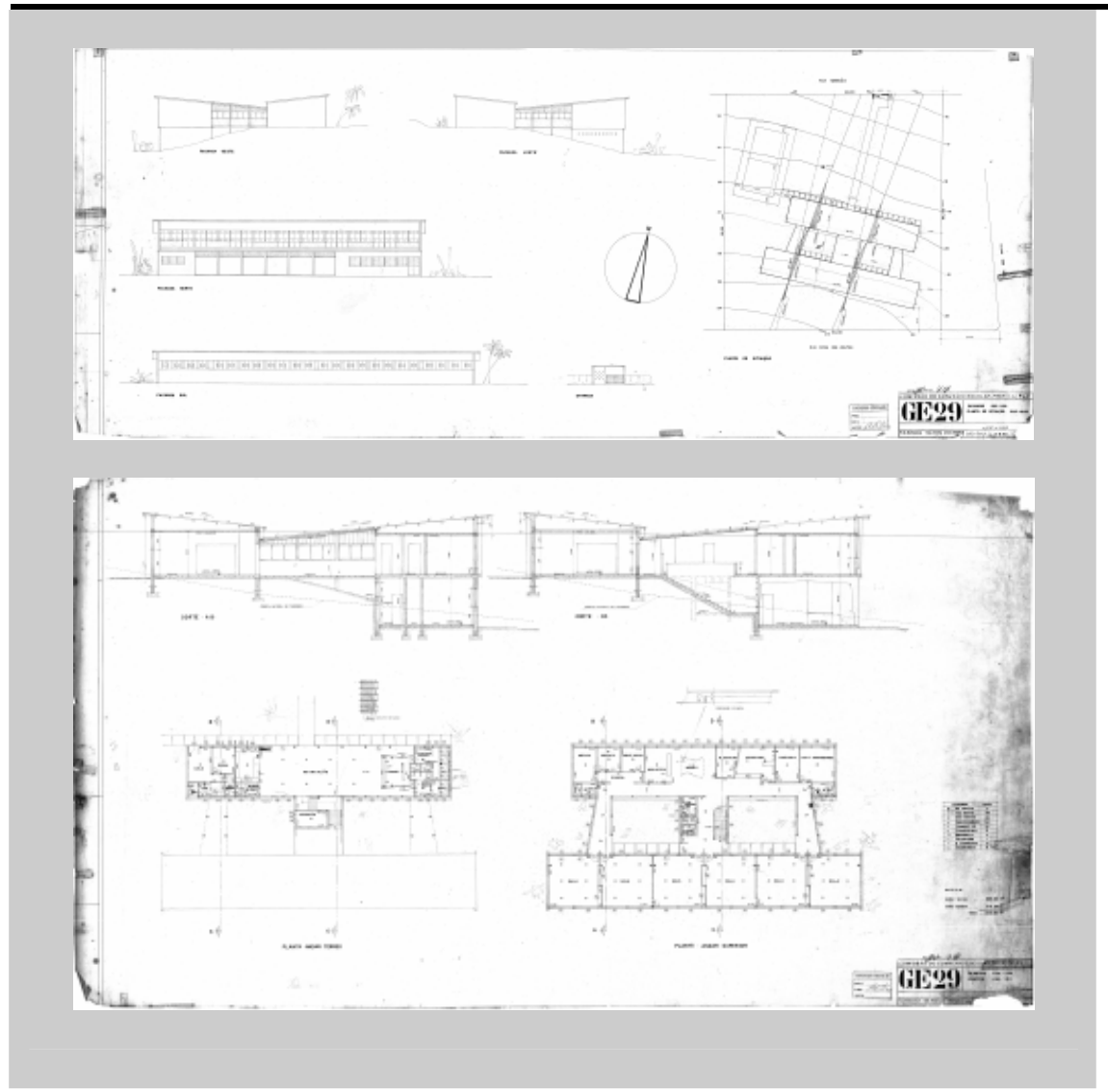

Datado de 9 de setembro de 1950. Este é o único projeto dentro da seqüência vista até aqui que não possui o corredor extenso que dá o acesso às salas de aula. Ao invés disso, há três acessos distintos que partem do bloco onde está o recreio coberto. Há modificações feitas em 15 de janeiro de 1954 por Jose E. Ganzeli e uma luminária projetada por Juvenal Waetge Junior. 
João Teodoro (G.E. 30)
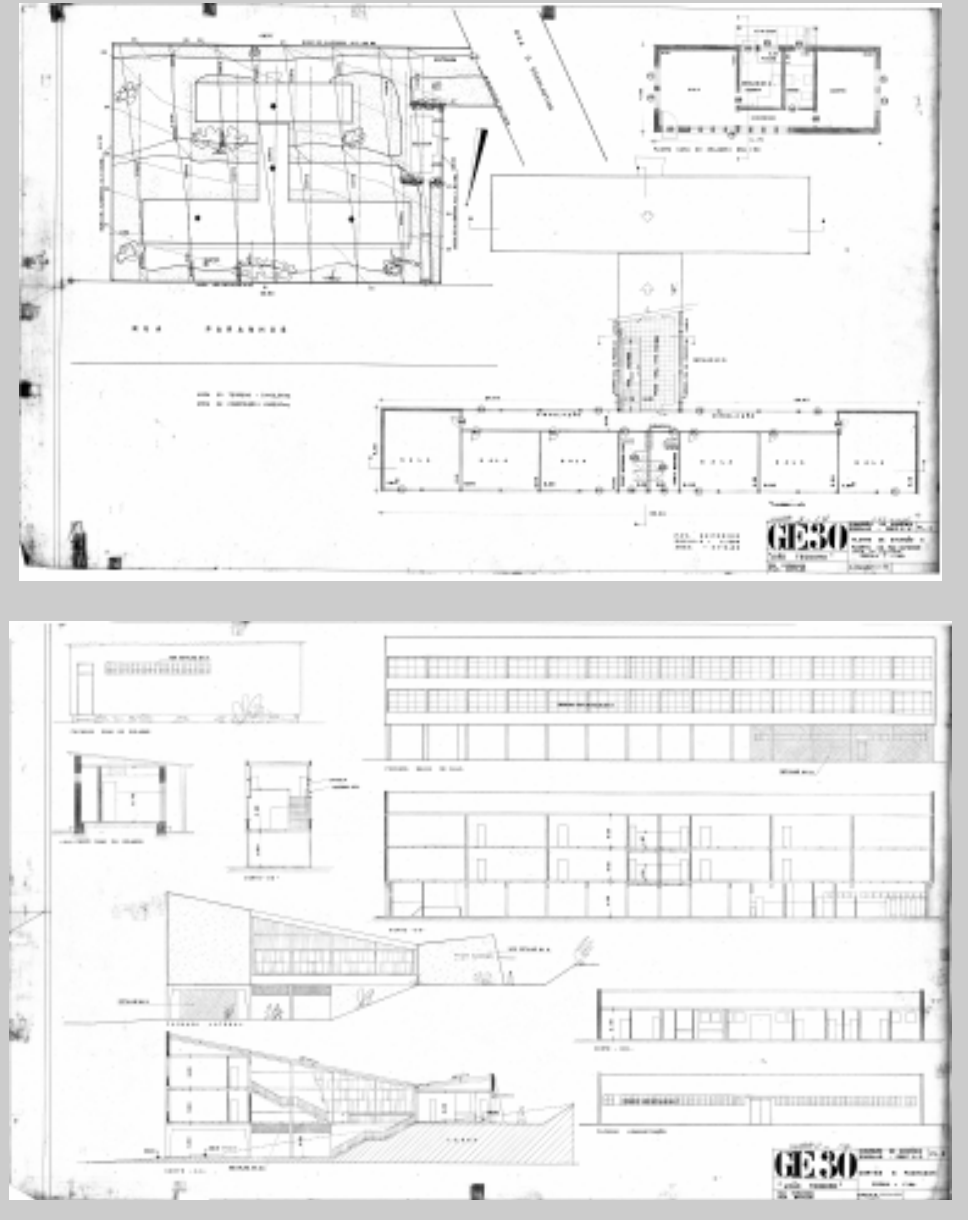

Datado de 31 de outubro de 1950. O projeto simétrico, o telhado com duas águas voltadas para o interior do volume (o típico telhado "borboleta" da época) e a aparência industrial são marcas dessa escola, situada em um terreno de pequenas proporções para o padrão da época.

General Antônio Sampaio (G.E. 31)

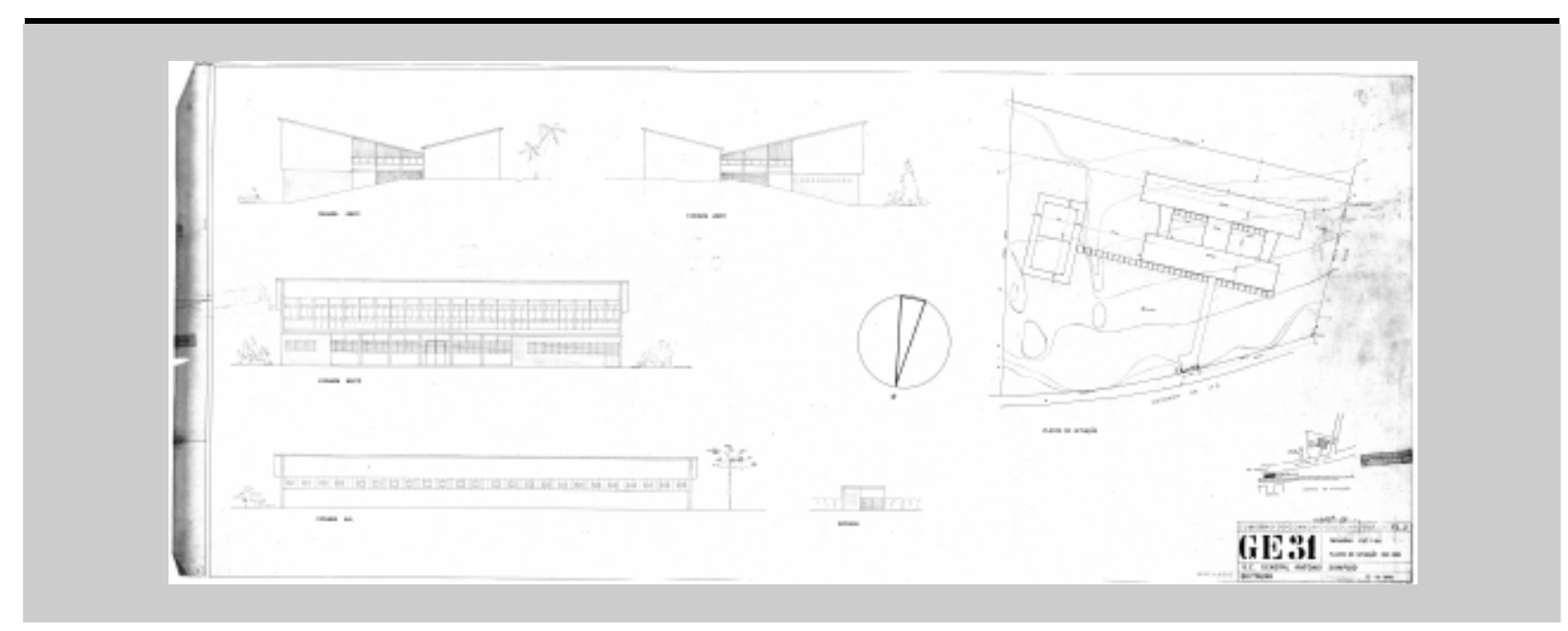

Datado de 17 de outubro de 1950. O projeto é muito semelhante ao G.E. 29. A solução em ambos os projetos permitia uma adequação a terrenos com declive acentuado. No caso do G.E. 31 foi adaptada apenas a cobertura das passarelas que vinculam o bloco de salas de aula ao restante da edificação Algumas pequenas intervenções foram feitas em 12 de agosto de 1952. 
Cidade Líder (G.E. 32)

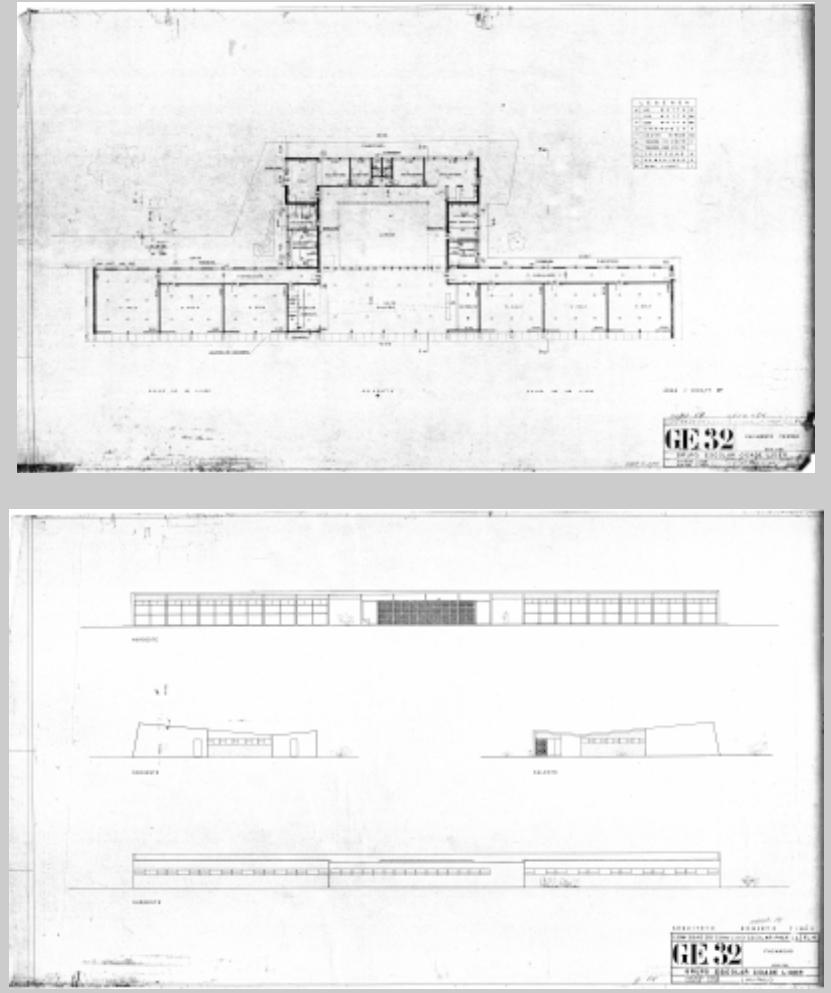

Projeto de Roberto Tibau. Era uma proposta de edificação econômica ${ }^{72}$ para ser construída mais rapidamente. Pode ser considerado de fato o projeto que mais se destaca da prática comum da época, junto com o de Vila Ema: não há uma associação de volumetrias e sim um edifício único.

Clovis Bevilacqua (G.E. 33)

I
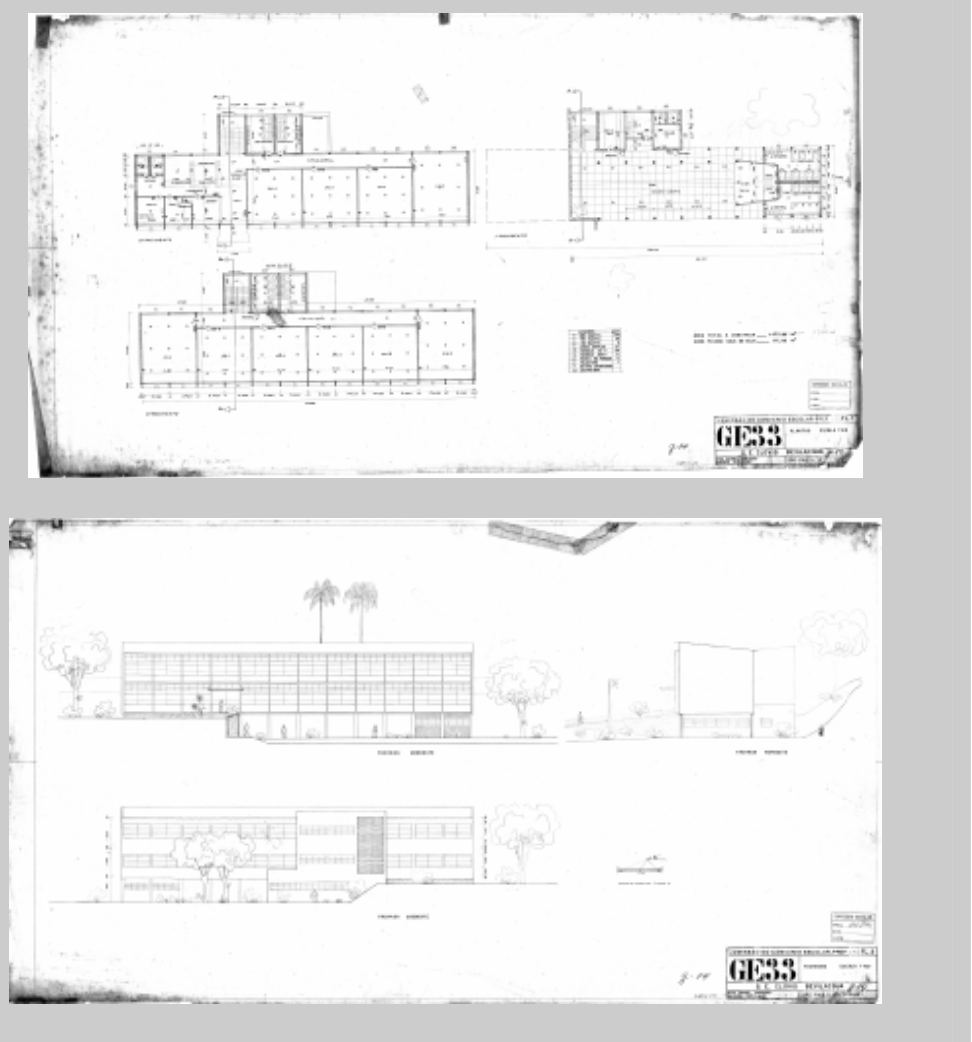

Datado de 10 de janeiro de 1950 e de 6 de março de 1951, da autoria de Roberto Tibau. É a escola mais compacta das que foram mostradas até agora.

A assinatura na modificação não está legível. 
Couto Magalhães (G. E. 34)

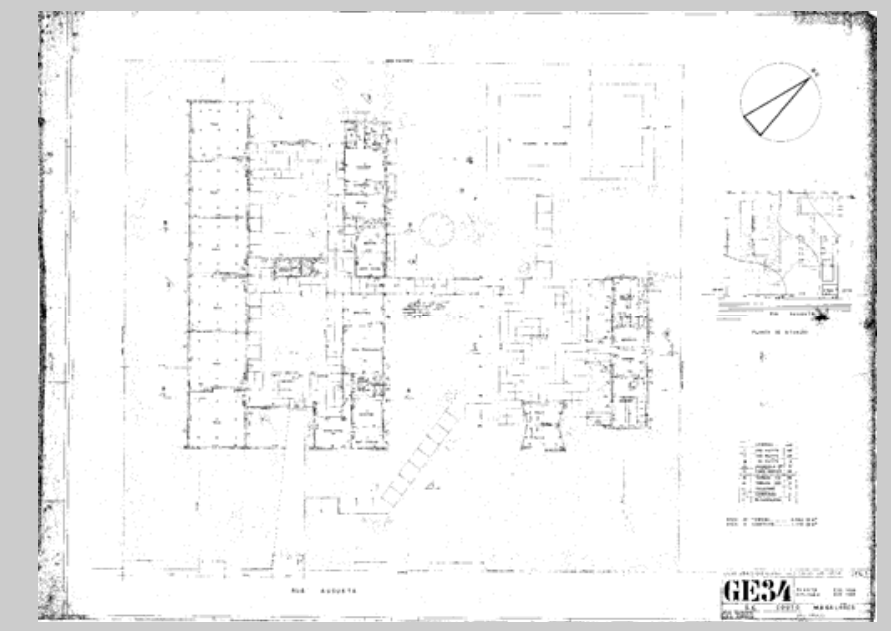

Projeto de 30 de novembro de 1950.

A eliminação do longo corredor de acesso às salas de aula é a principal inovação desse projeto em relação ao que se fazia na época.

República do Paraguai (G. E. 35)

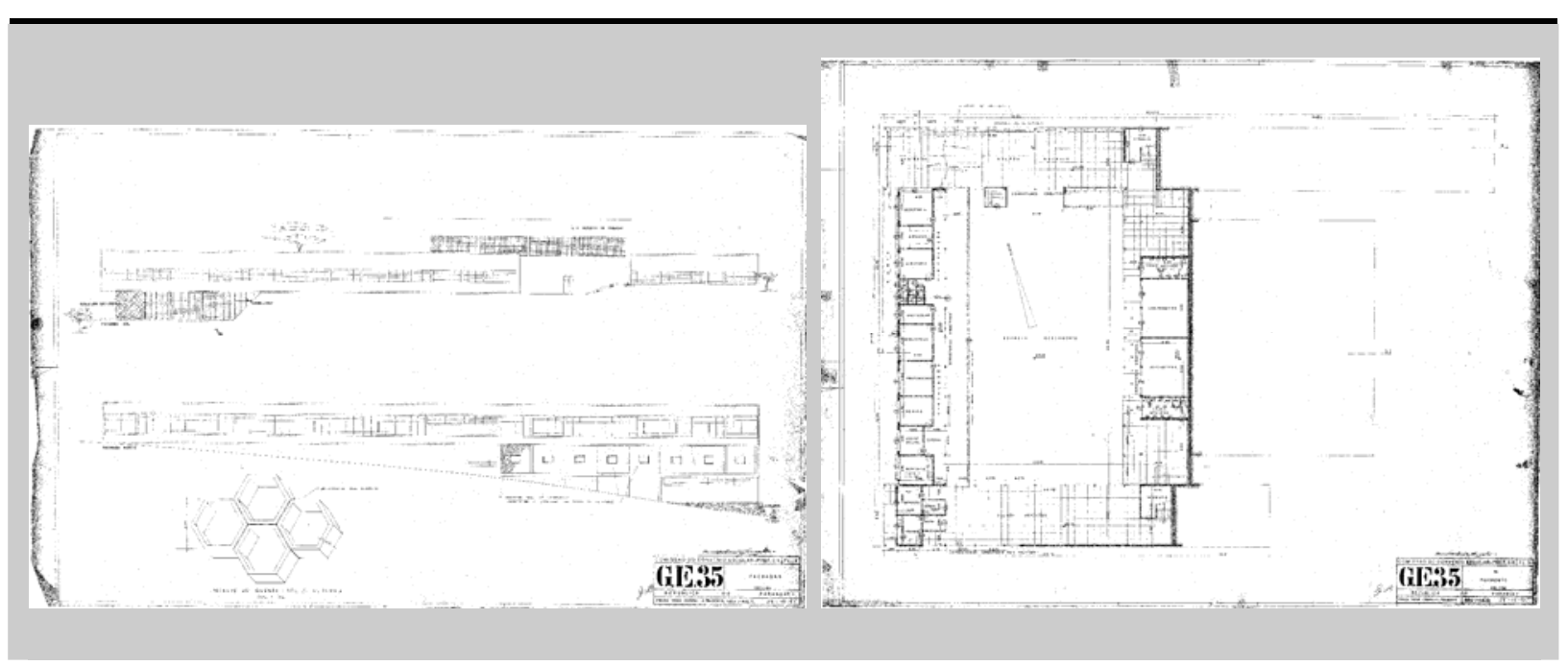

Localizado na Vila Prudente, o projeto é de 29 de outubro de 1951, de Oswaldo Corrêa Gonçalves.

Frei Gaspar da Madre de Deus (G. E. 36)

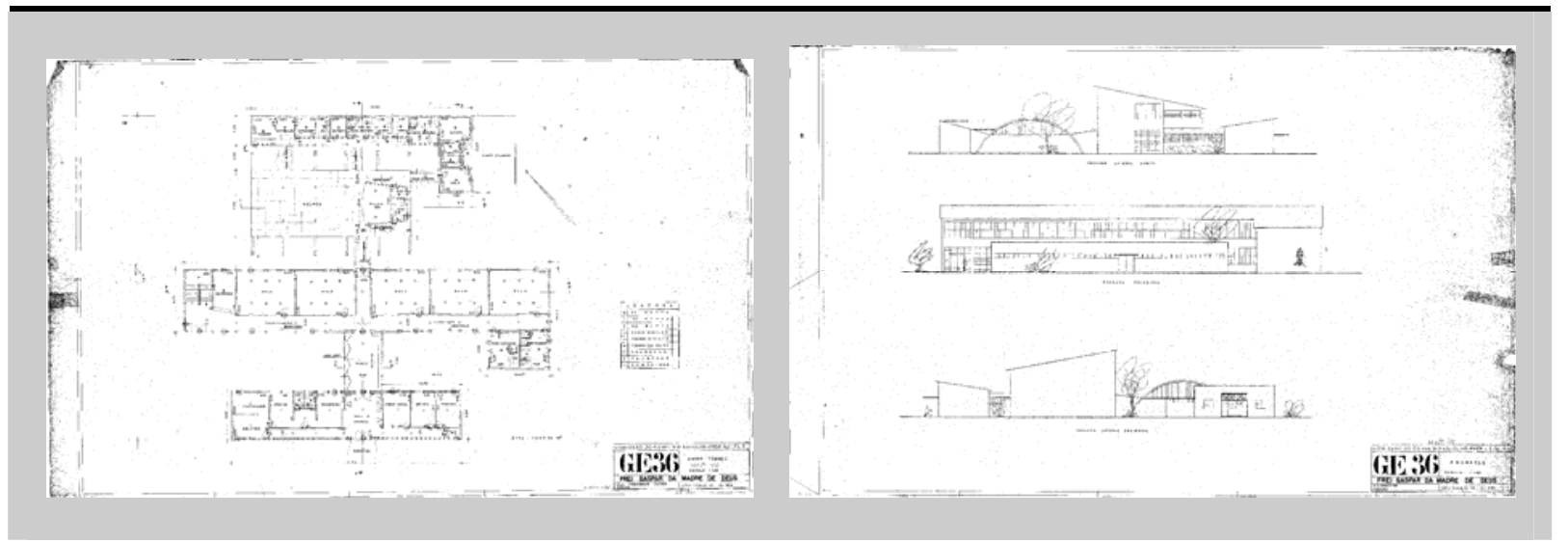

Projeto datado de 15 de dezembro de 1950, utiliza o corredor central com os volumes dispostos perpendicularmente a ele. É um recurso típico para resolver o acesso a mais de um bloco com o menor corredor possível. 
Gabriel Ortiz (G. E. 38)

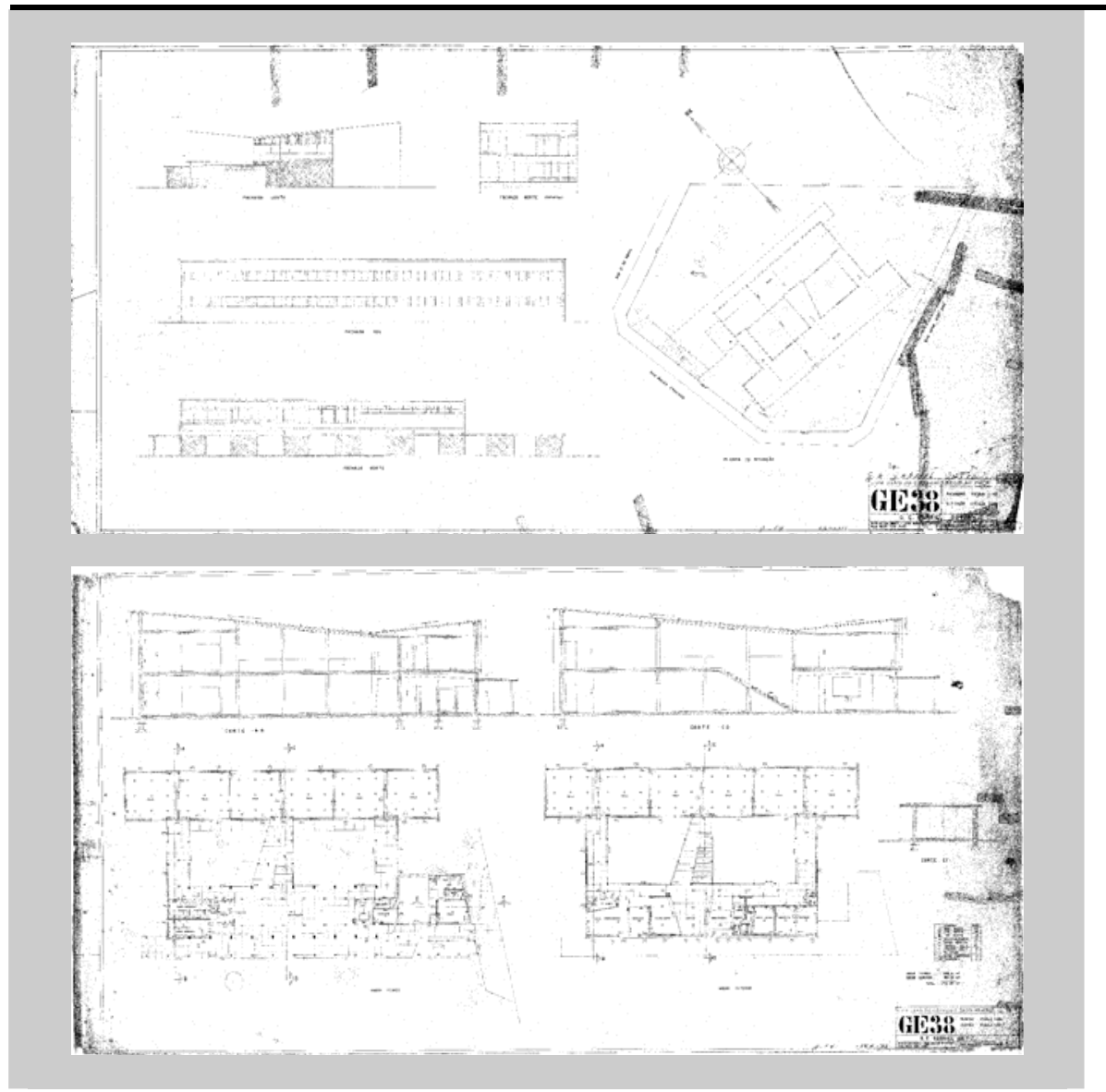

Passou a ser chamado de E. N. G. E. Domingos Faustino Sarmiento. O projeto é de 10 de janeiro de 1950, de Ernesto Mange. Aqui o autor continua a desenvolver o tema da escola sem corredor, criando acessos separados para as salas de aula a partir do galpão de recreação.

Escola de Aplicação Água Branca (G. E. 39)

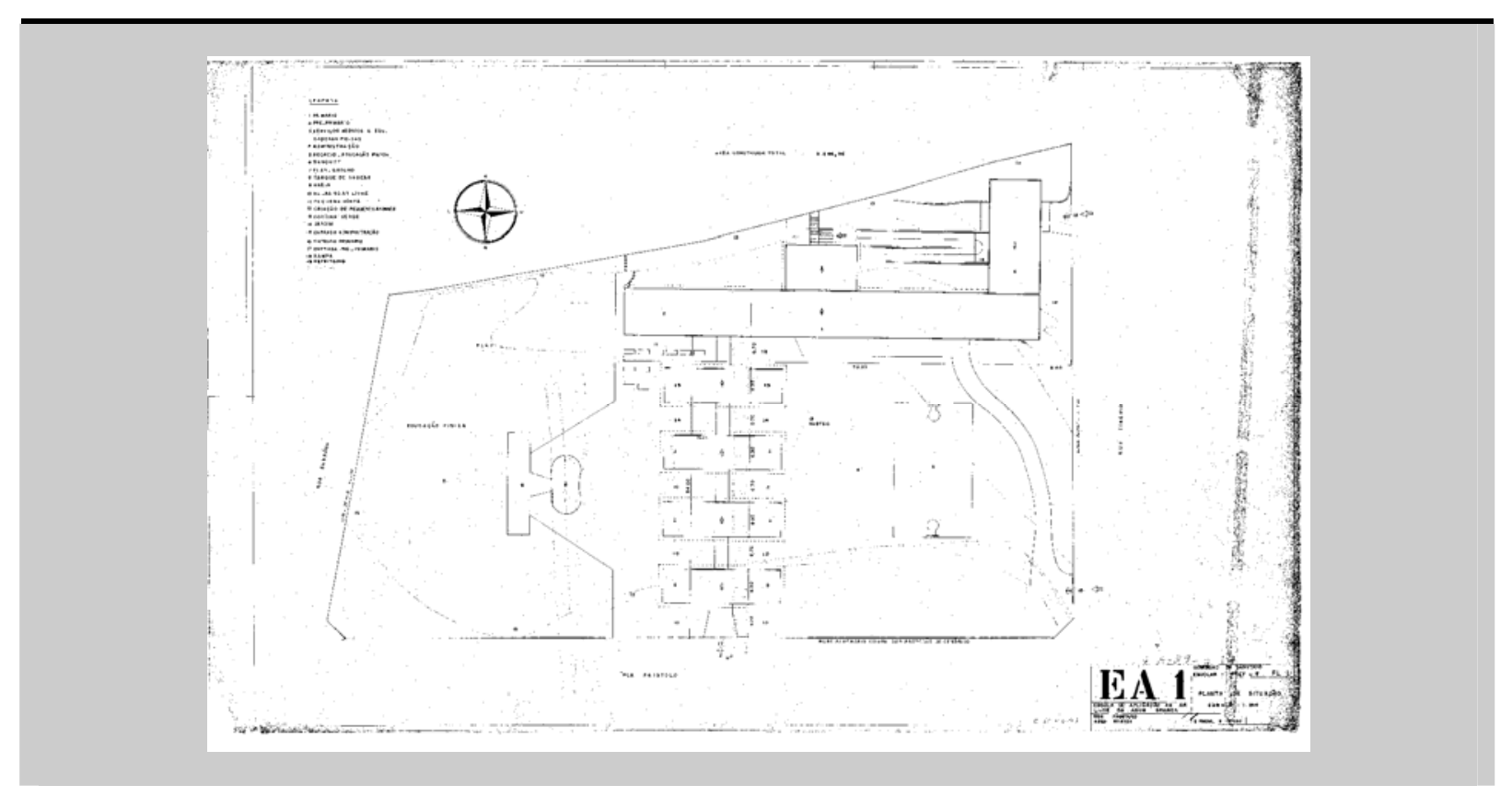

Há uma numeração específica que indica a referência E. A. 1, mas não foram encontradas outras escolas com essa referência. O projeto é de 02 de setembro de 1950, de Roberto Tibau. 
Benedito Tolosa (G. E. 41)

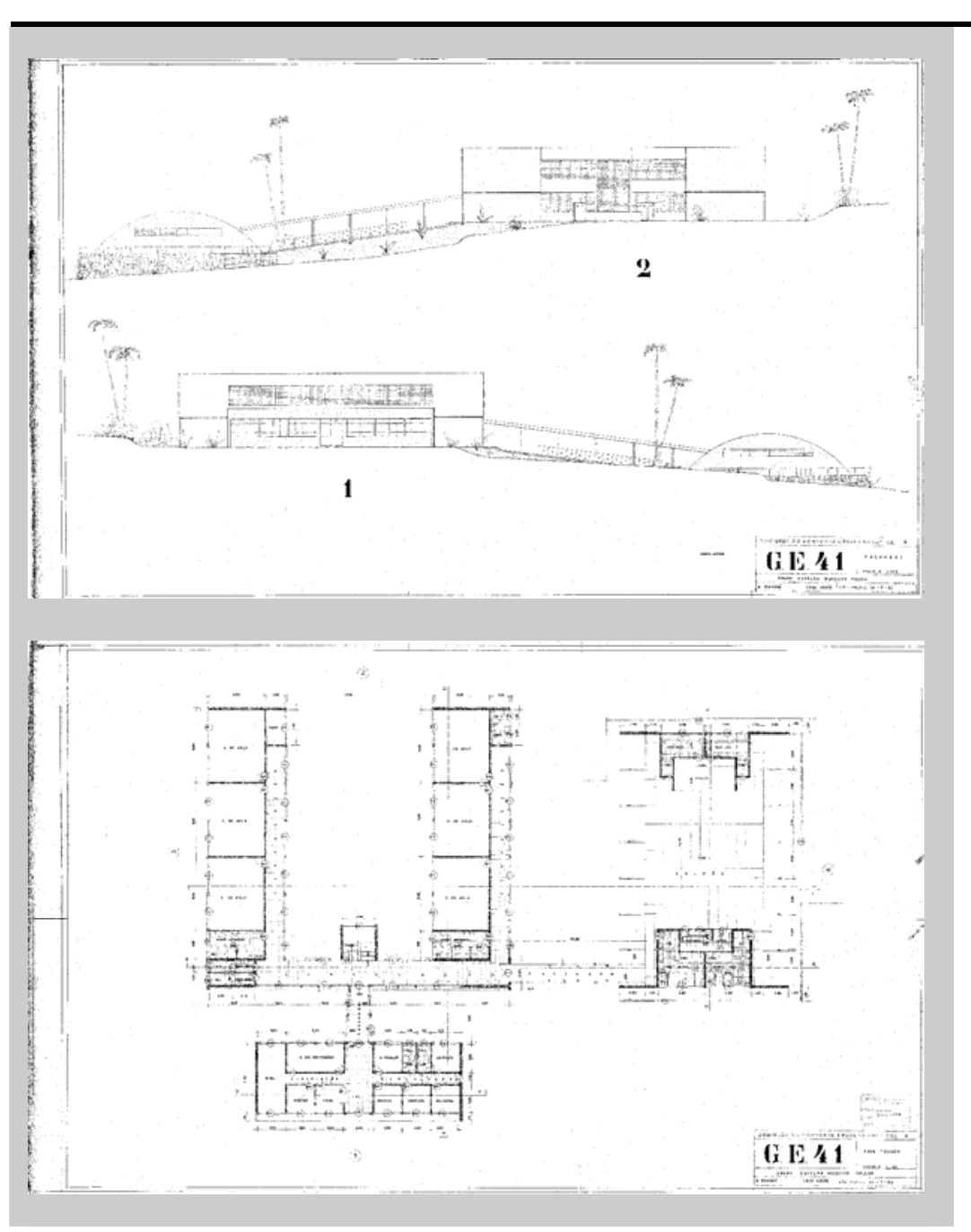

Projeto com datas de 7 de abril e 31 de julho de 1953. Há o carimbo do desenhista Benito Mangini, mas o autor do projeto não foi identificado. A adequação à difícil topografia é mais tranqüila pelo uso da composição aditiva: cada bloco fica em uma cota distinta. $\mathrm{O}$ problema se restringe à circulação entre os blocos.

José Bonifácio (G. E. 42)

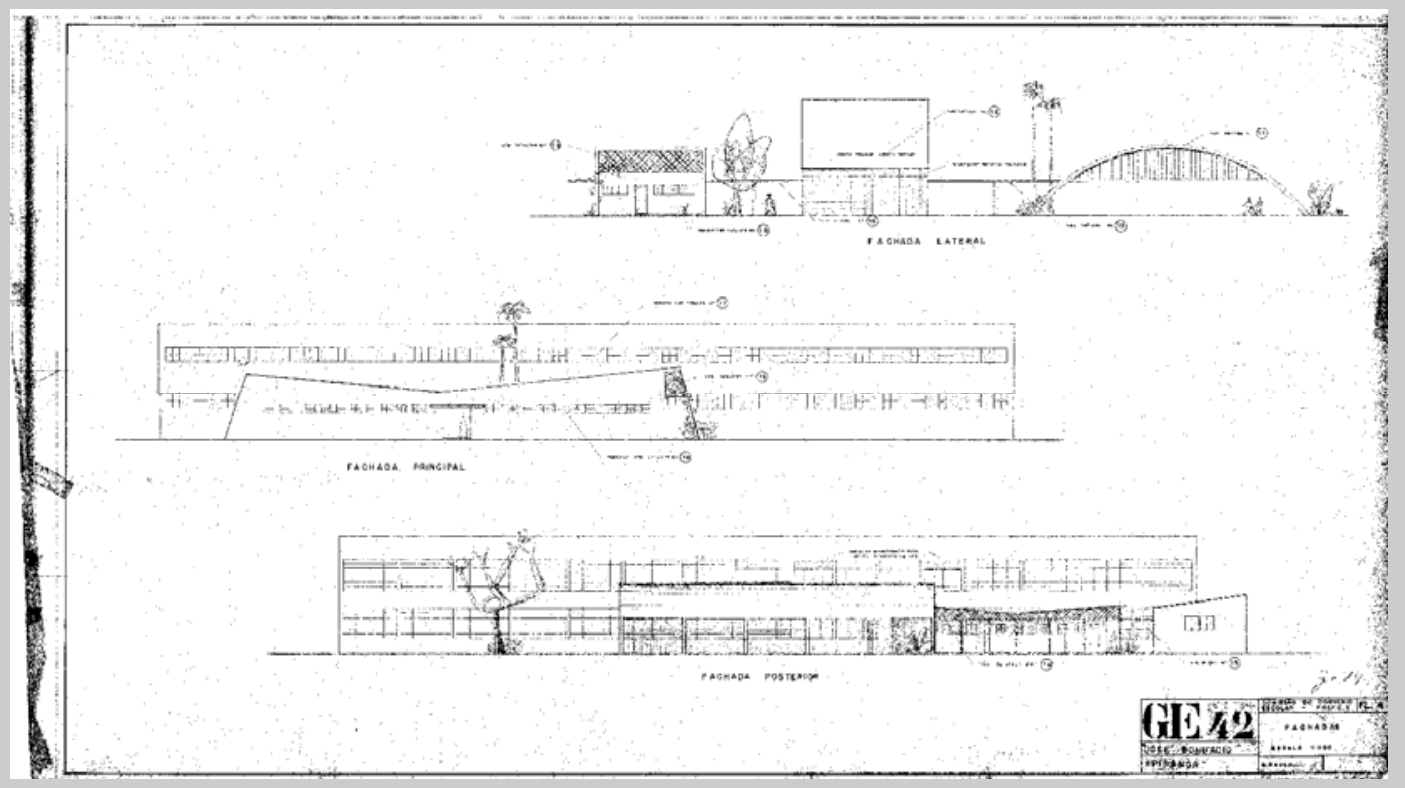

Projeto sem data e sem identificação do autor. É um projeto típico. Note-se as palmeiras, sempre presentes nos desenhos das fachadas. 
Engenheiro Goulart (G. E. 43)

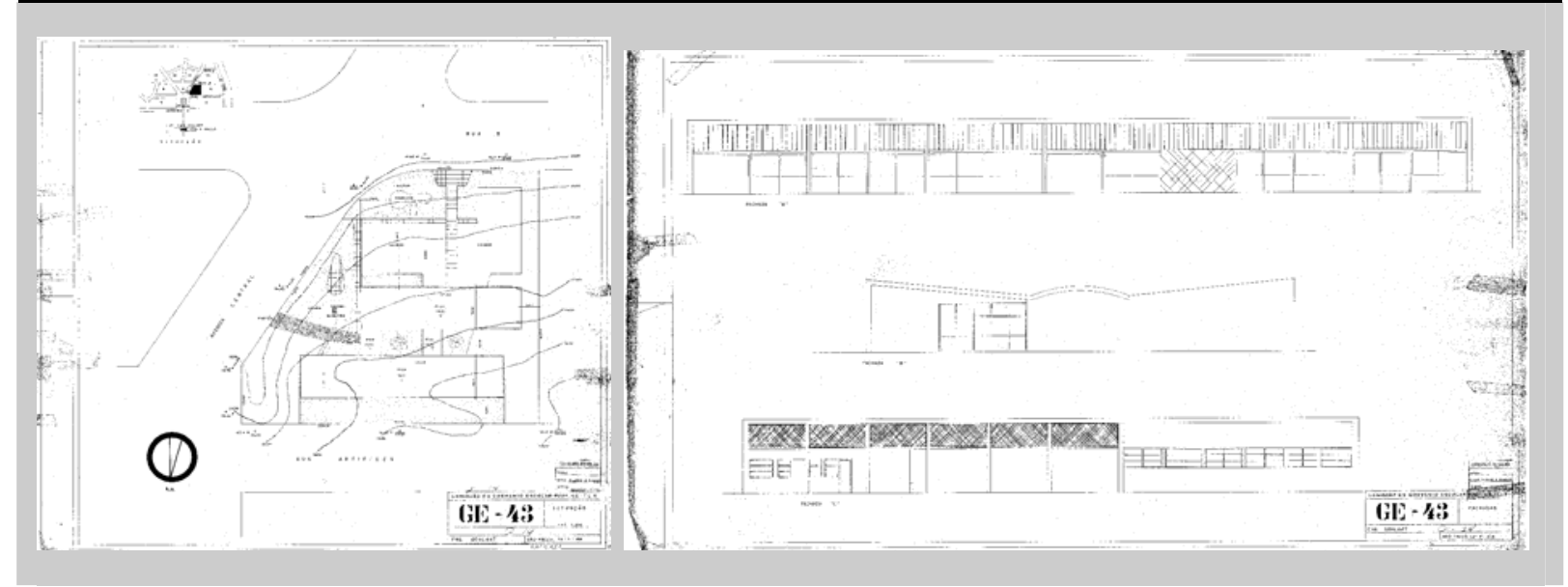

Projeto com data de 12 de janeiro de 1953. A presença do muxarabi é uma constante nas áreas de circulação das escolas.

Aristides de Castro (G. E. 44)

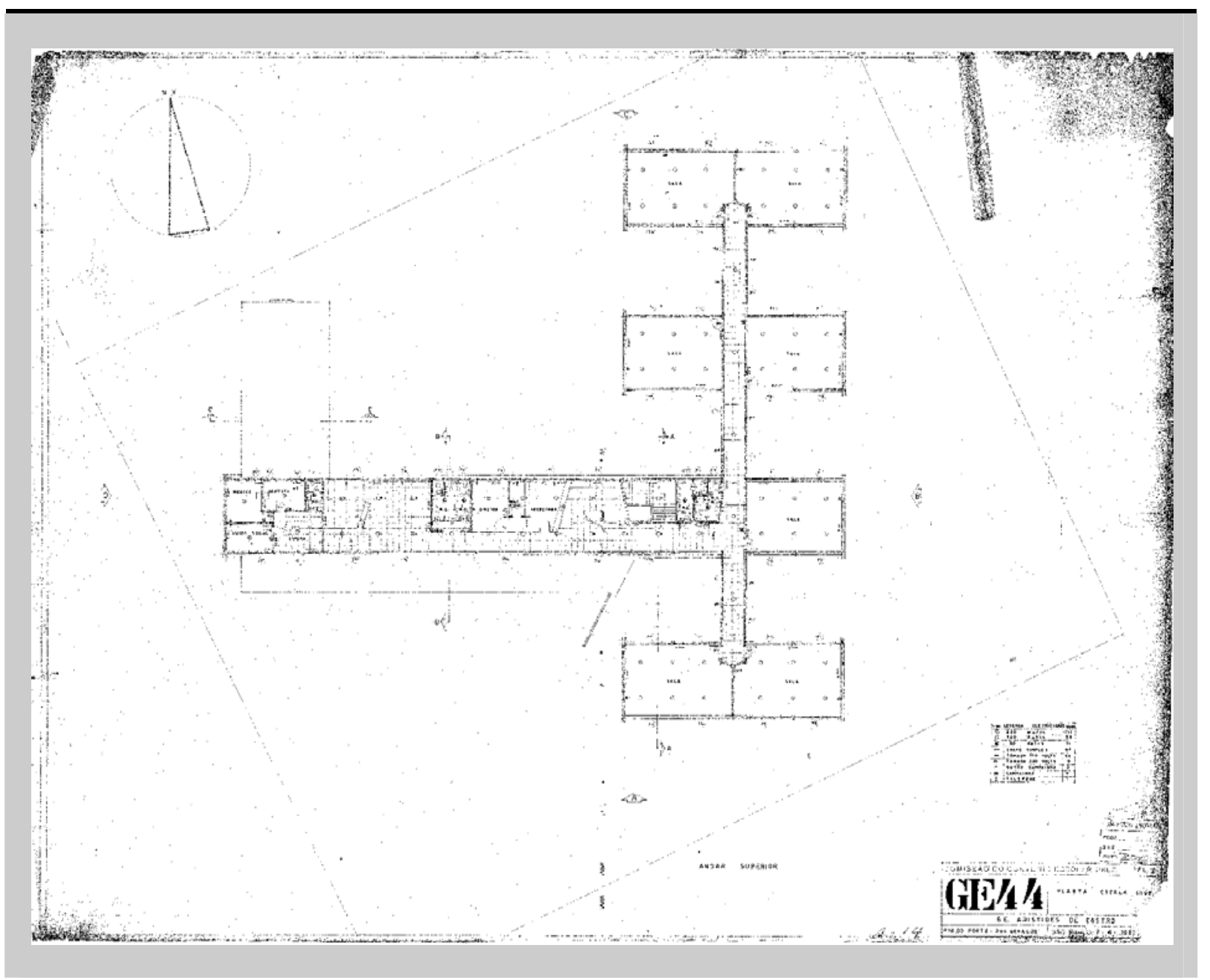

Com data de 7 de abril de 1951, esta escola possui uma composição volumétrica que foi utilizada em outros projetos, como na Escola de Aplicação Água Branca. O uso de salas distantes umas das outras permite a criação de áreas livres, para as quais abrem-se as classes. 
Taipas (G. E. 45)

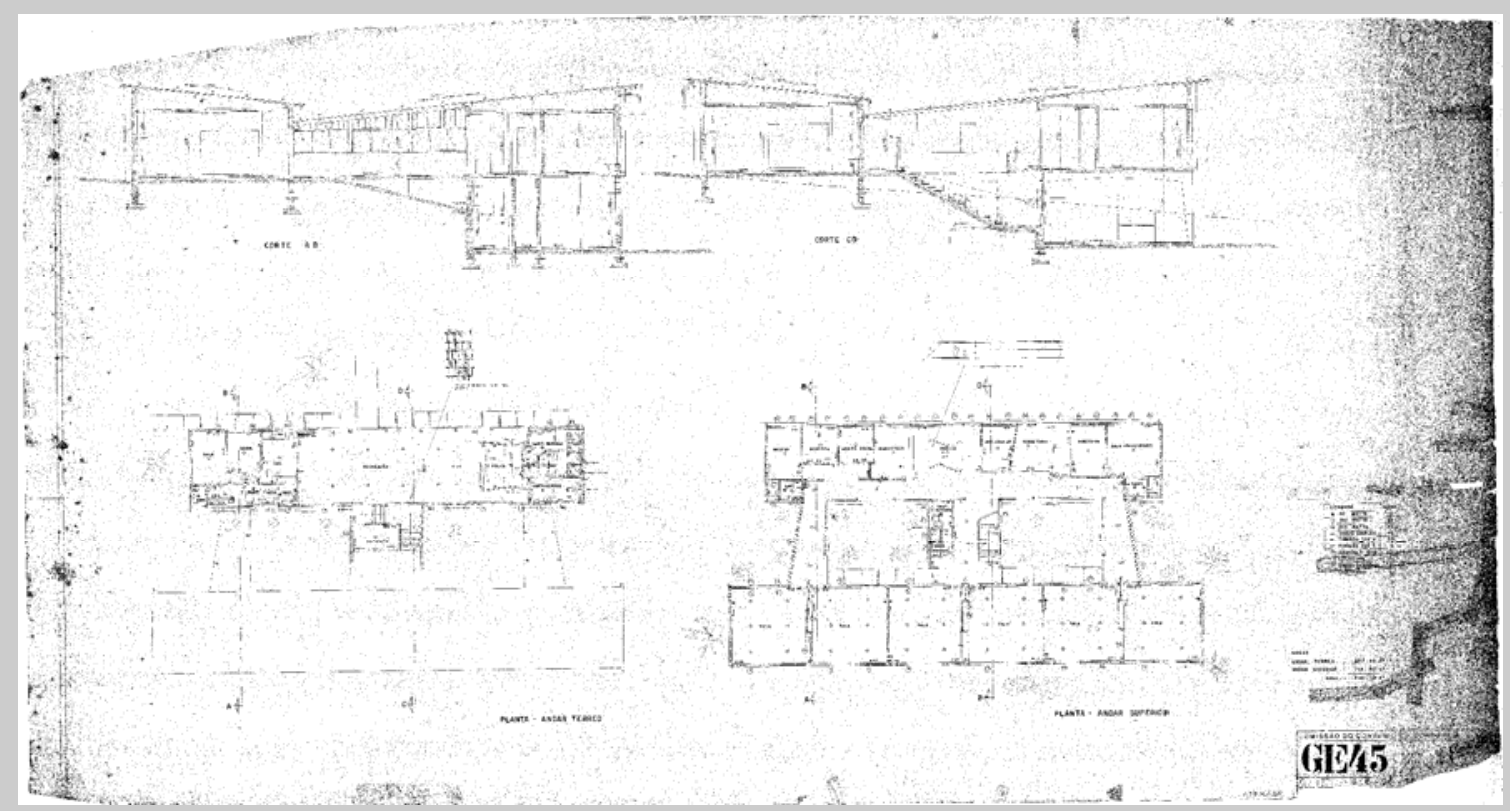

Também conhecida como Jaraguá, o projeto desta escola data de 12 de abril de 1951.

Zalina Rolim (G. E. 46)

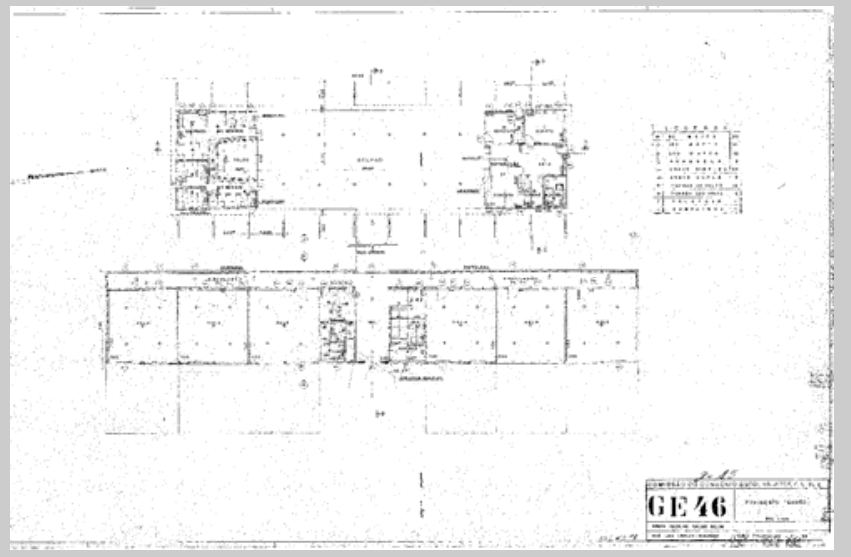

Projeto de 21 de janeiro de 1954. Apesar da grande quantidade de salas de aula (12 no total) é uma escola compacta.
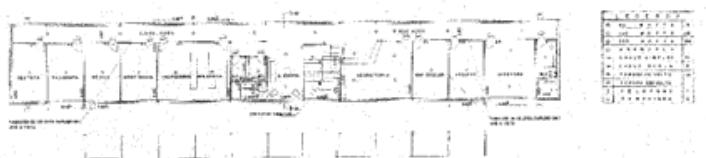
Nelson Fernandes (G. E. 47)

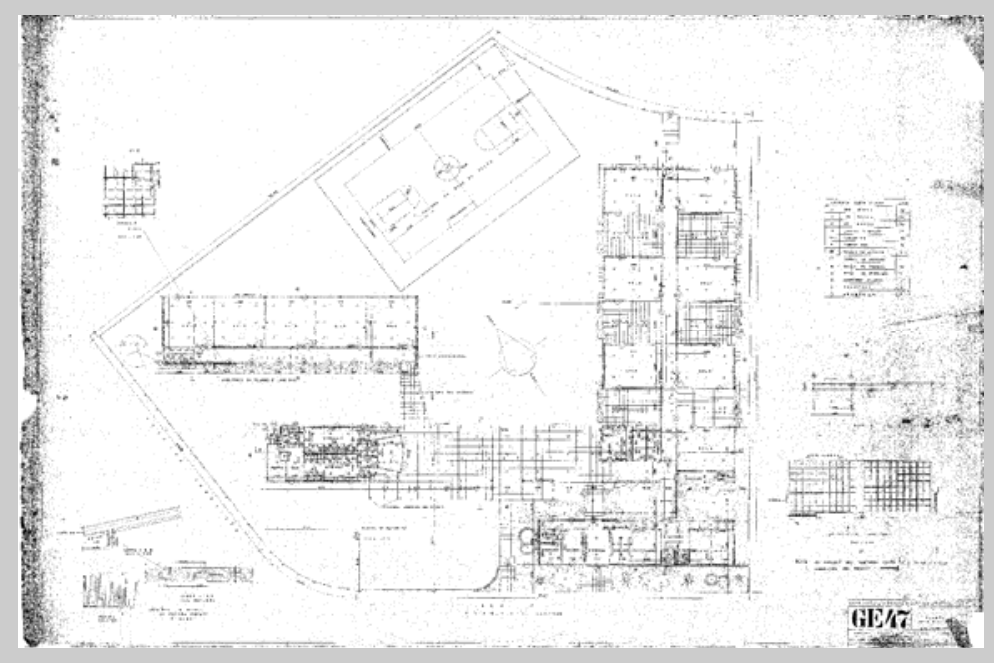

$\mathrm{O}$ projeto tem as datas de 02 de julho de 1951 e 04 de julho de 1951. A disposição das salas de aula permite sua abertura para pequenos jardins isolados.

\section{籍}

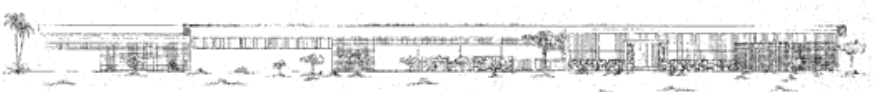

\section{GE/ $/$ -}

Paulo Setúbal (G. E. 48)

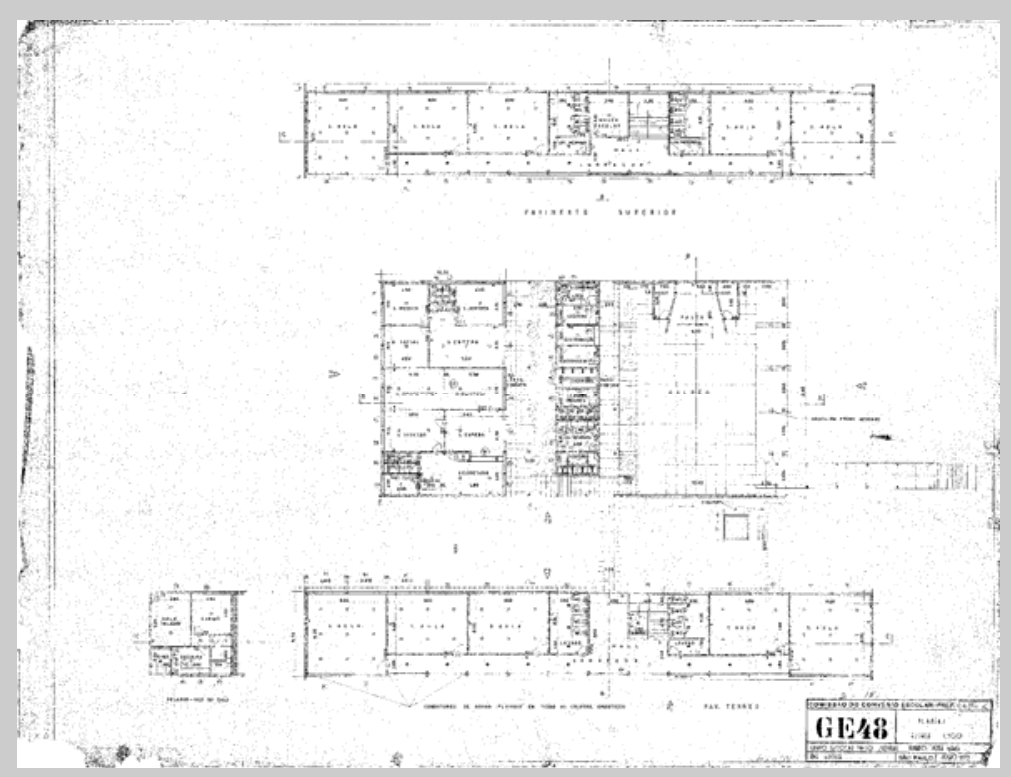

O projeto foi feito durante o mês de junho de 1952, com uma disposição dos blocos incomum: a união parcial da administração, do galpão e de áreas de atendimento complementar não era algo comum em escolas desse porte. 
Portugal (G. E. 49)

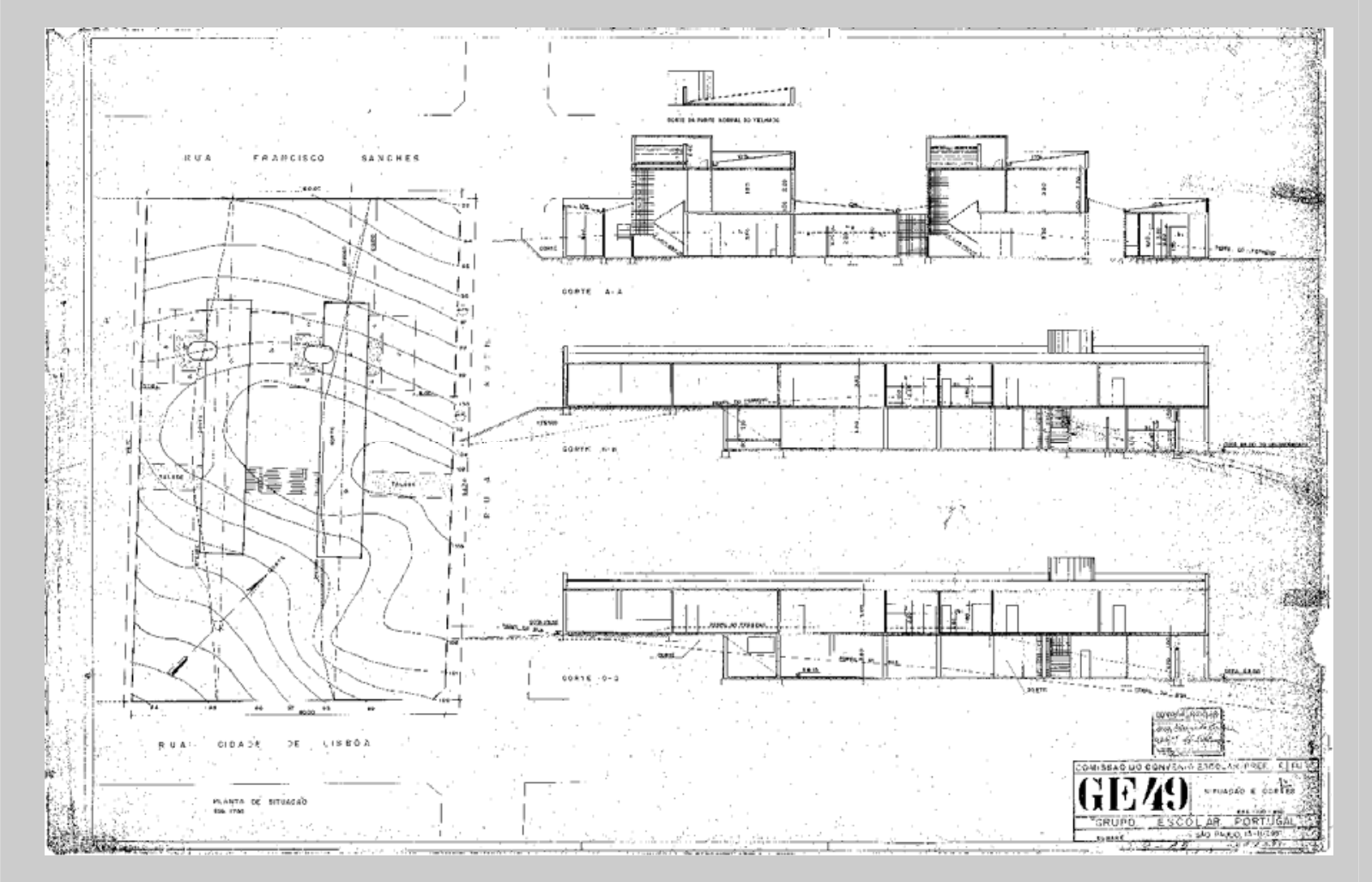

Projeto de 13 de novembro de 1951, de Eduardo Corona. A adaptação à topografia prev a organização do espaço livre situado em torno do edifício.

Estação XV de Novembro (G. E. 50)

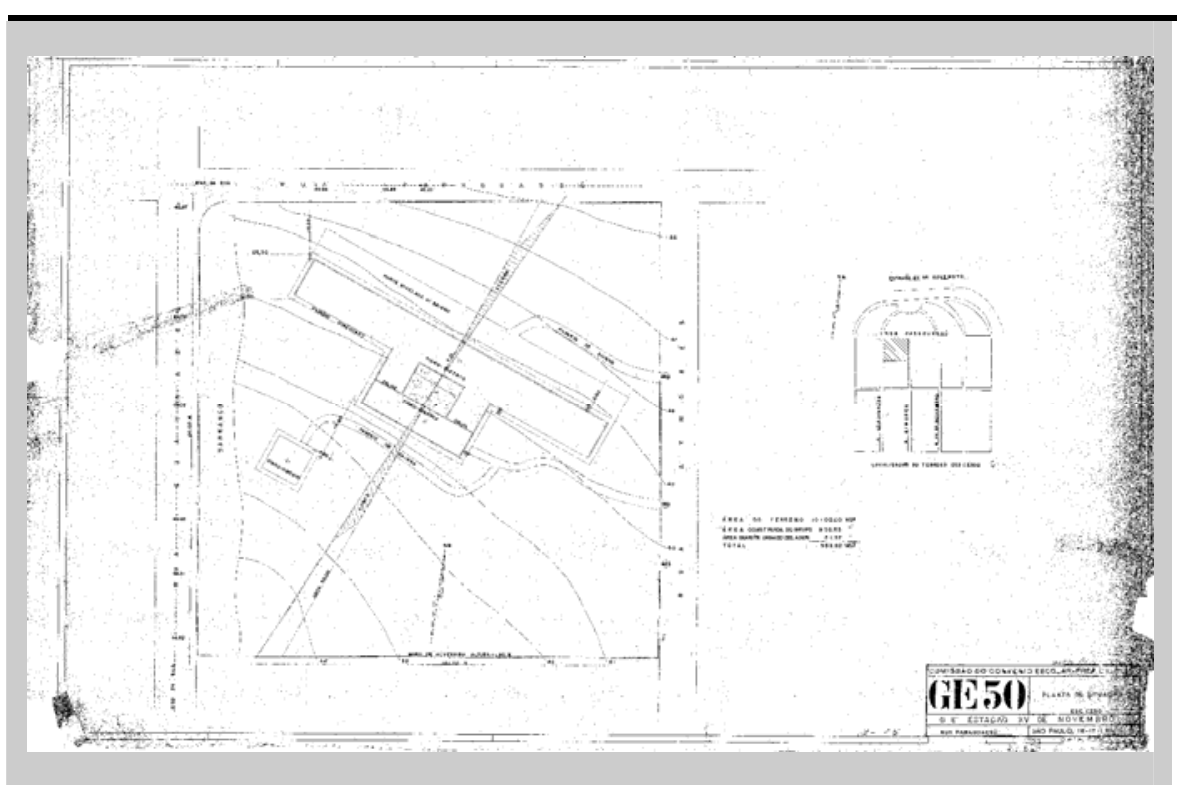

Projeto de autoria de Roberto Tibau, de 18 de dezembro de 1951.Tratase do projeto econômico utilizado em outras escolas. A implantação privilegia a insolação e a topografia. 
Vila Mangalot (G. E. 51)
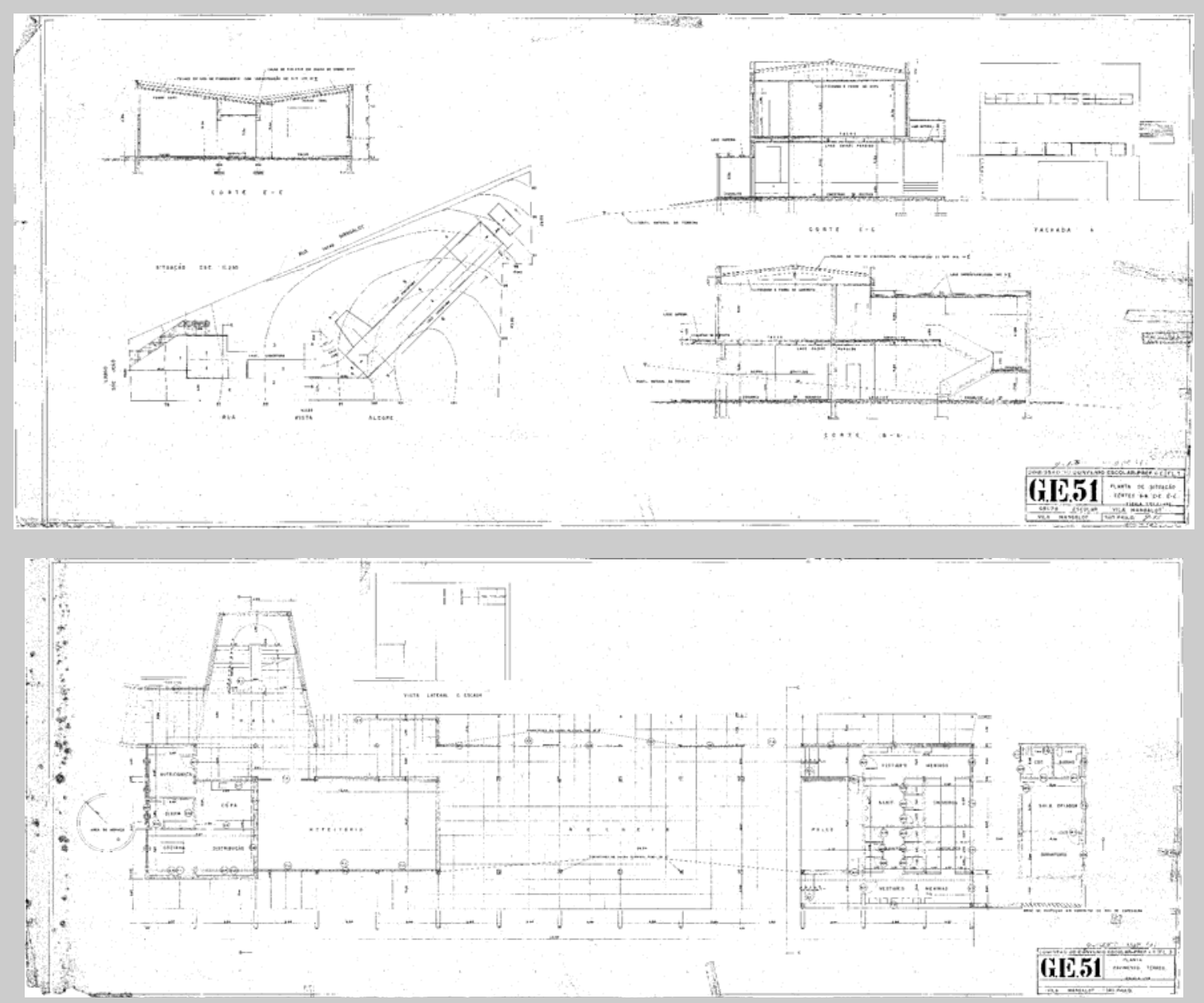

O projeto, com data de 04 de fevereiro de 1952, teve que ser adaptado ao terreno, bastante limitado em comparação a outros usados para implantação de escolas..

Escola para o Serviço Social de Menores (G. E. 52)

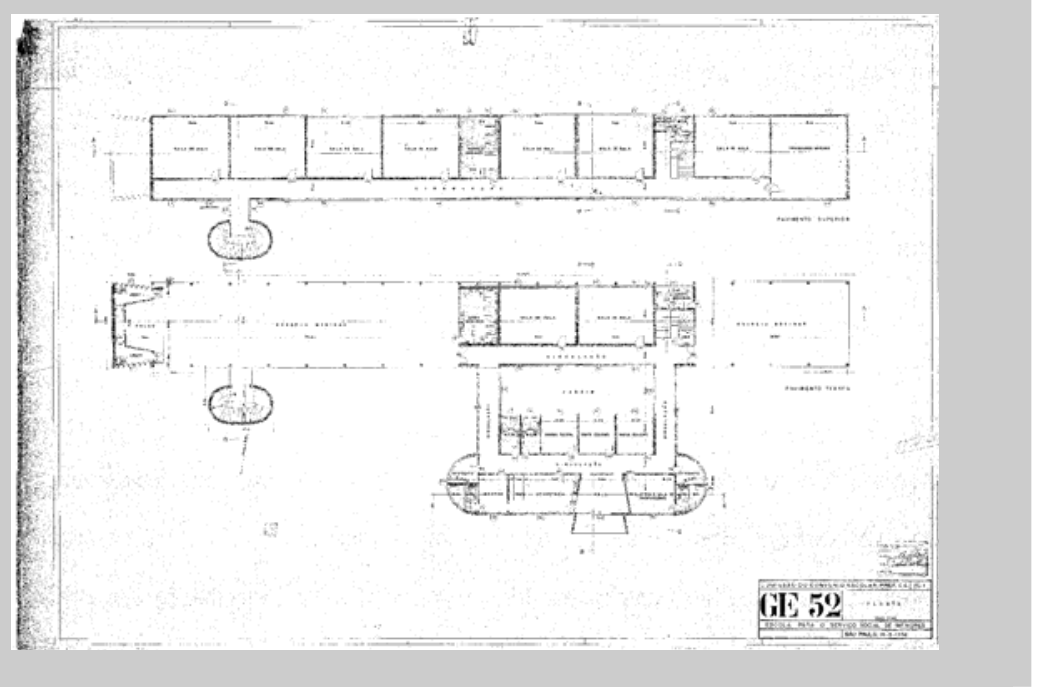

Datada de 4 e 14 de maio de 1952, foi o único projeto do gênero encontrado nos arquivos. Projeto de autoria de Roberto Tibau. 
Arthur Saboya (G. E. 53)

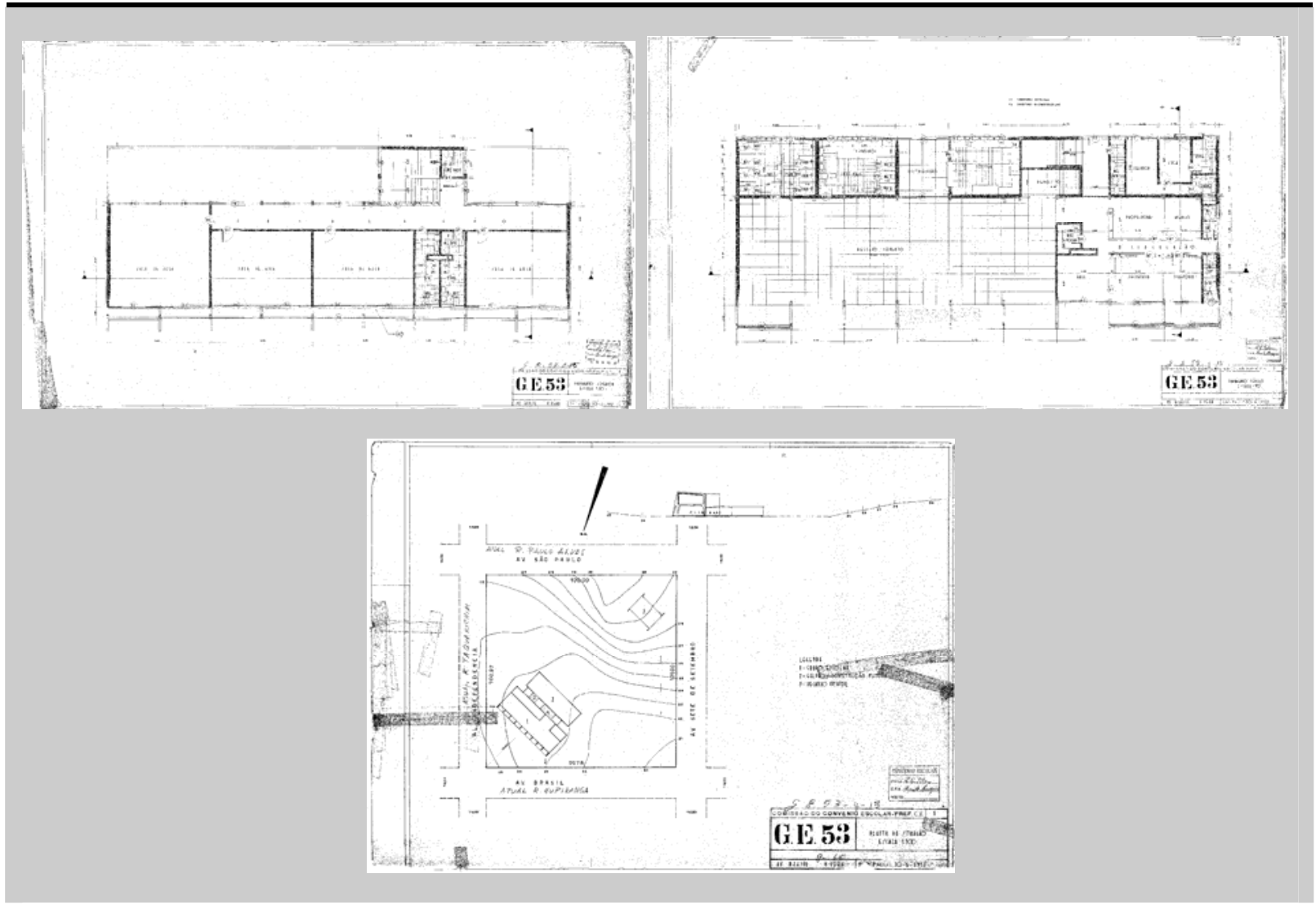

Projeto compacto, de baixo custo, de 30 de junho de 1952, de Roberto Tibau, localizado na Vila Vera.

Tomáz Galhardo (G. E. 54)

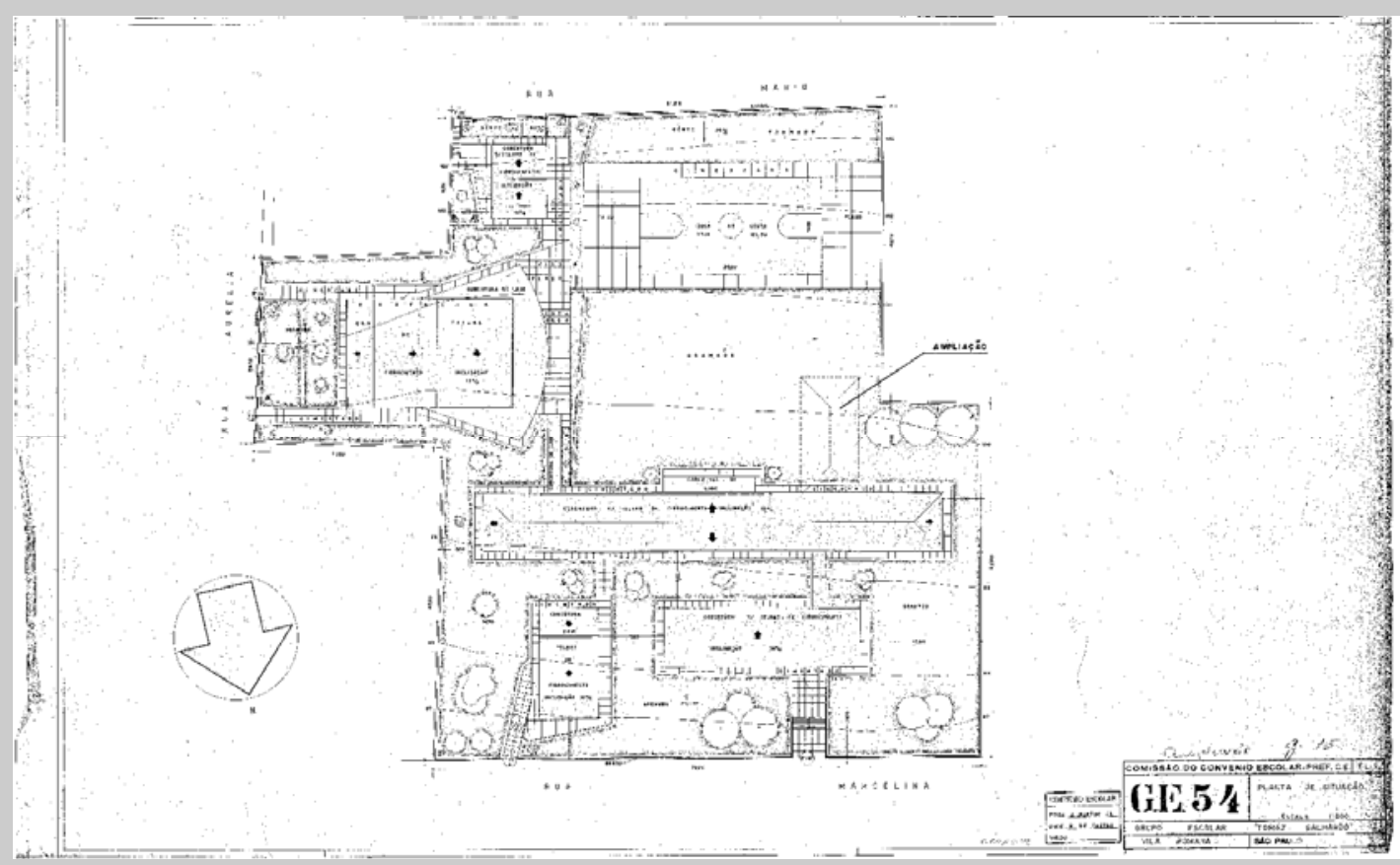

Datado de $1^{\circ}$ de outubro de 1952, localizado na Vila Romana, de Juvenal Waetge Jr. 
Júlio Pestana (G. E. 55)

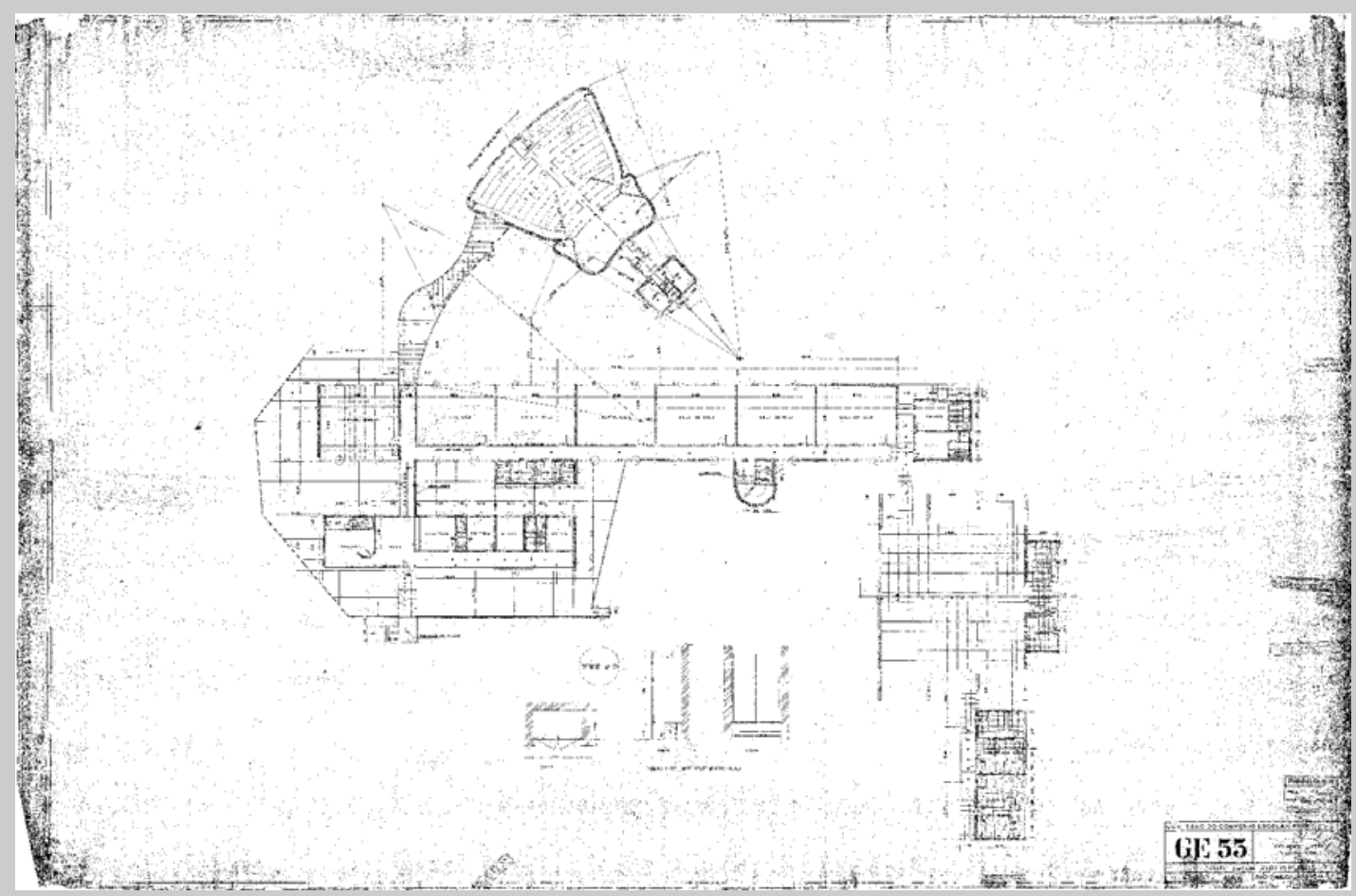

Localizado no Jaçanã, é datado de 28 e 29 de agosto de 1952. Esta escola possui um auditório com desenho sofisticado, pouco convencional em comparação às instalações do mesmo gênero.

São João Clímaco (G. E. 56)

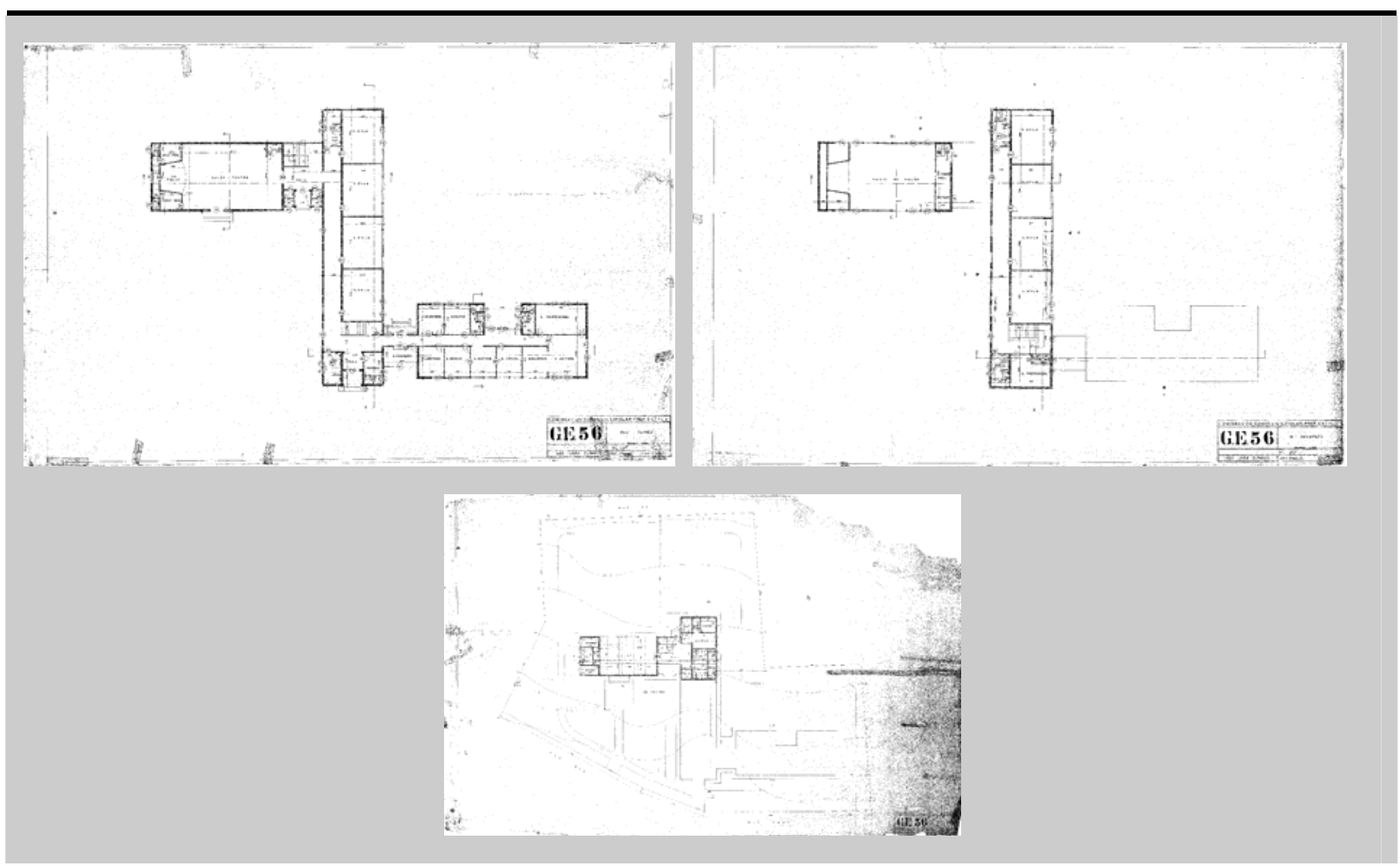

O projeto tem datas de 30 de julho e 12 de agosto de 1952. 
Aclimação (G. E. 57)

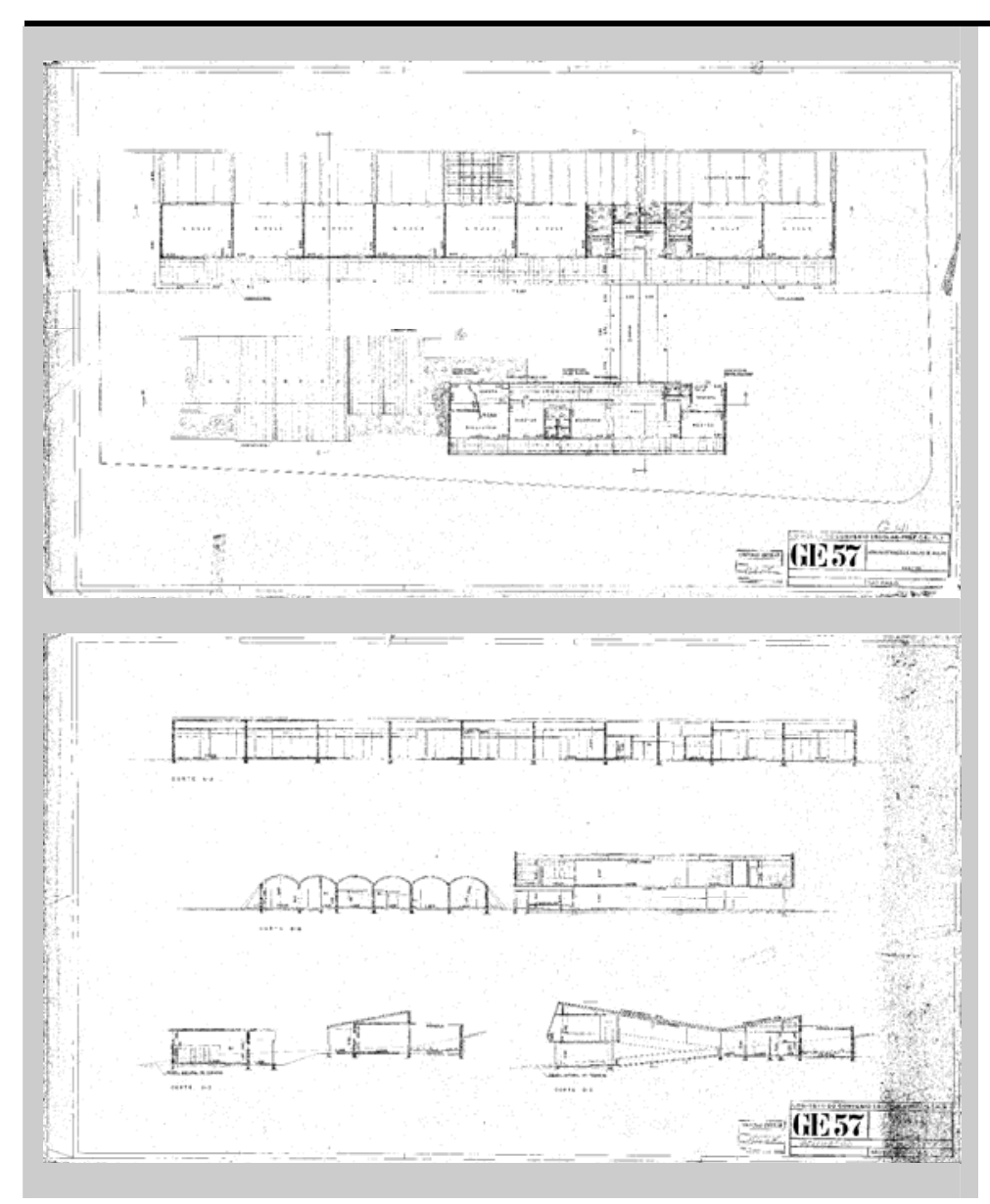

A implantação desta escola e o aproveitamento da topografia geram uma implantação e uma volumetria bastante rica, com rampas e o uso de abóbadas em seqüência, que tanto sucesso fizeram nos projetos da década de 1950.

Parque Edu Chaves (G. E. 58)

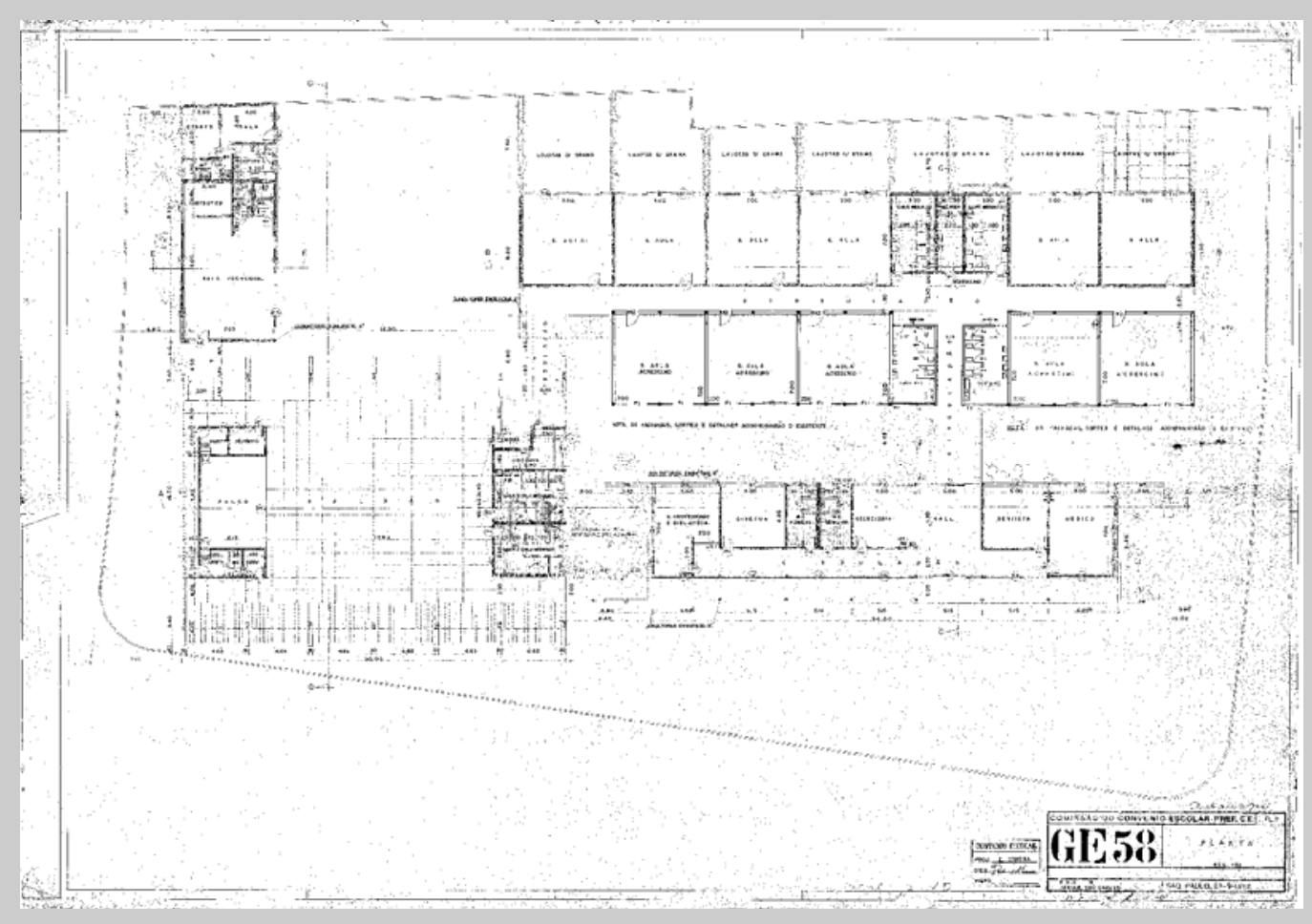

Projeto de 29 de setembro de 1952, de Eduardo Corona. 
Deputado Pedro Costa (G. E. 59)

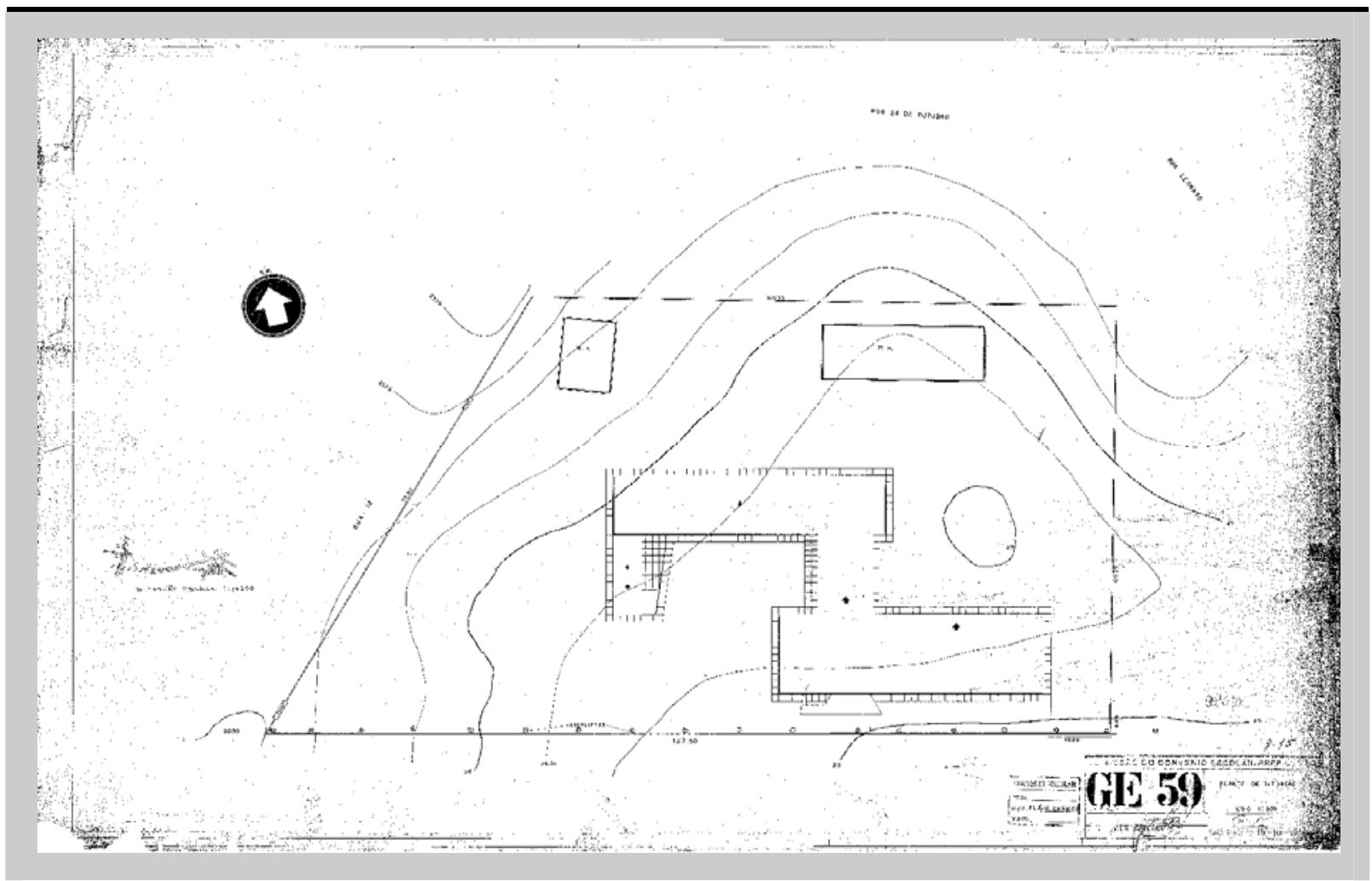

Situado em Vila Izolina, datado de 15 de outubro de 1952.

Vila Moraes (G. E. 60)

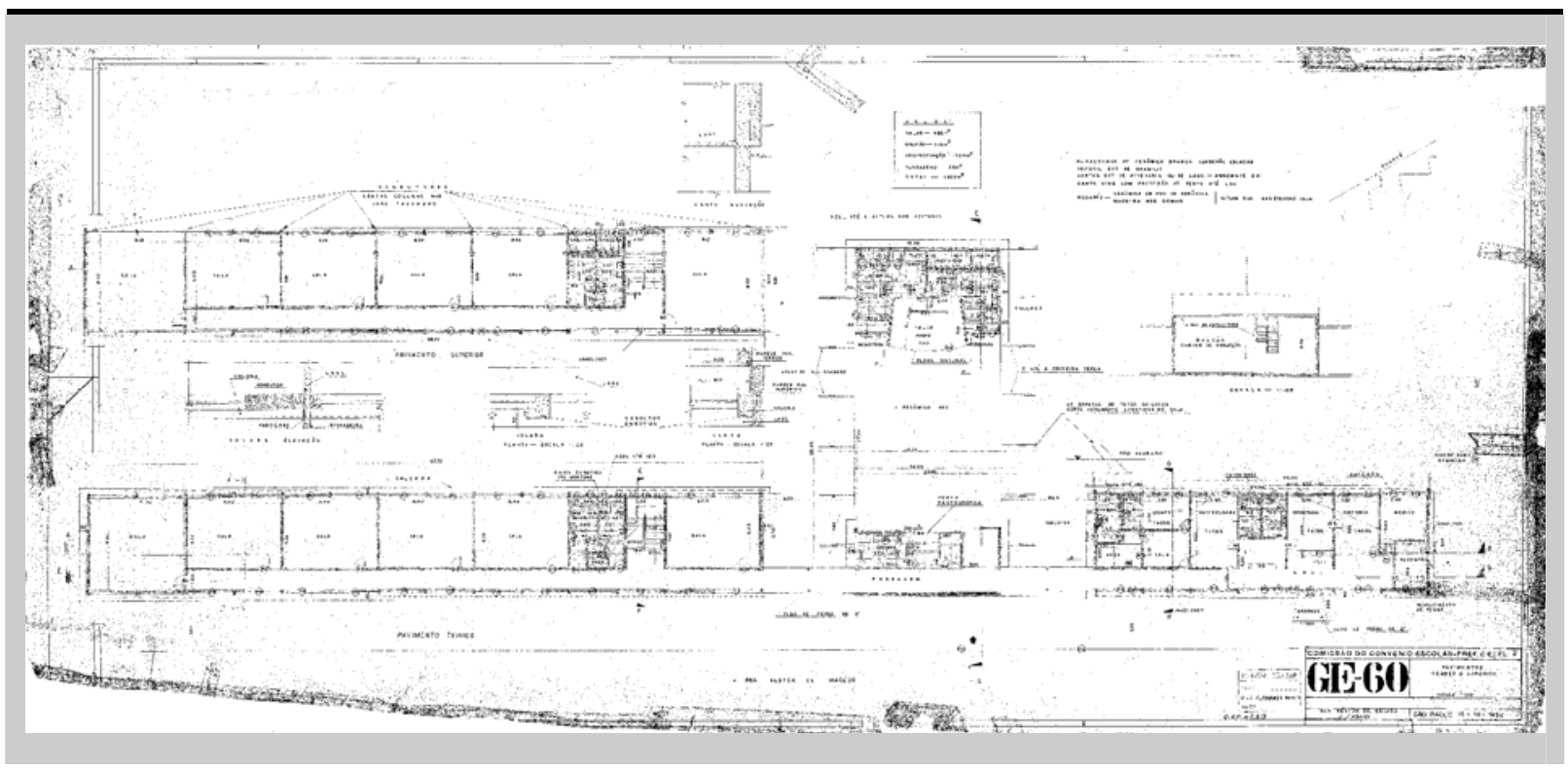

O primeiro desenho está datado de 15 de outubro de 1952 e o último de 11 de agosto de 1954. A autoria é de Roberto Tibau. 
Canindé (G. E. 61)

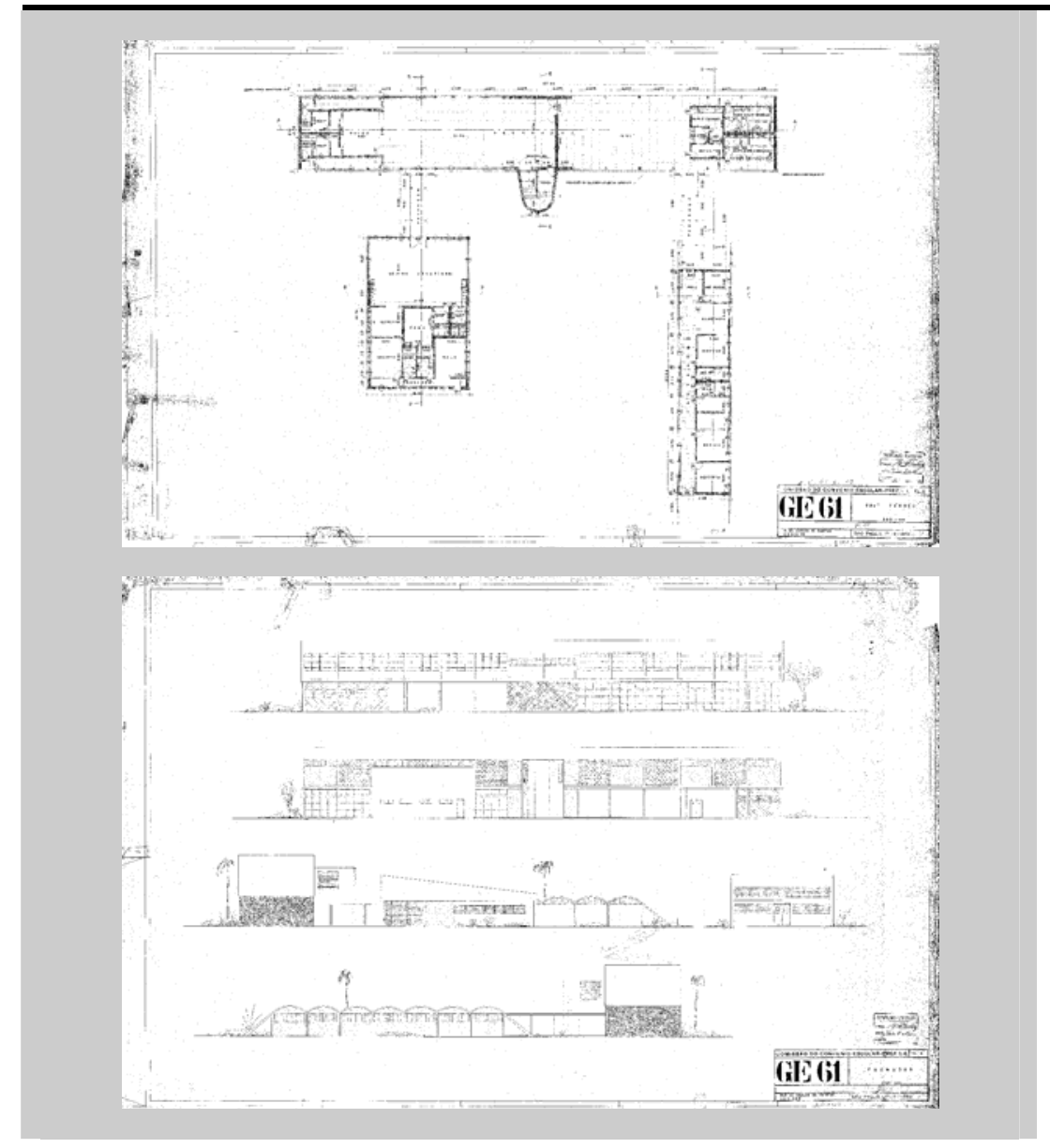

A data é de 17 de novembro de 1952 e 02 de julho de 1954. O autor é Antonio Pitombo.

Vila Palmeiras (G. E. 63)

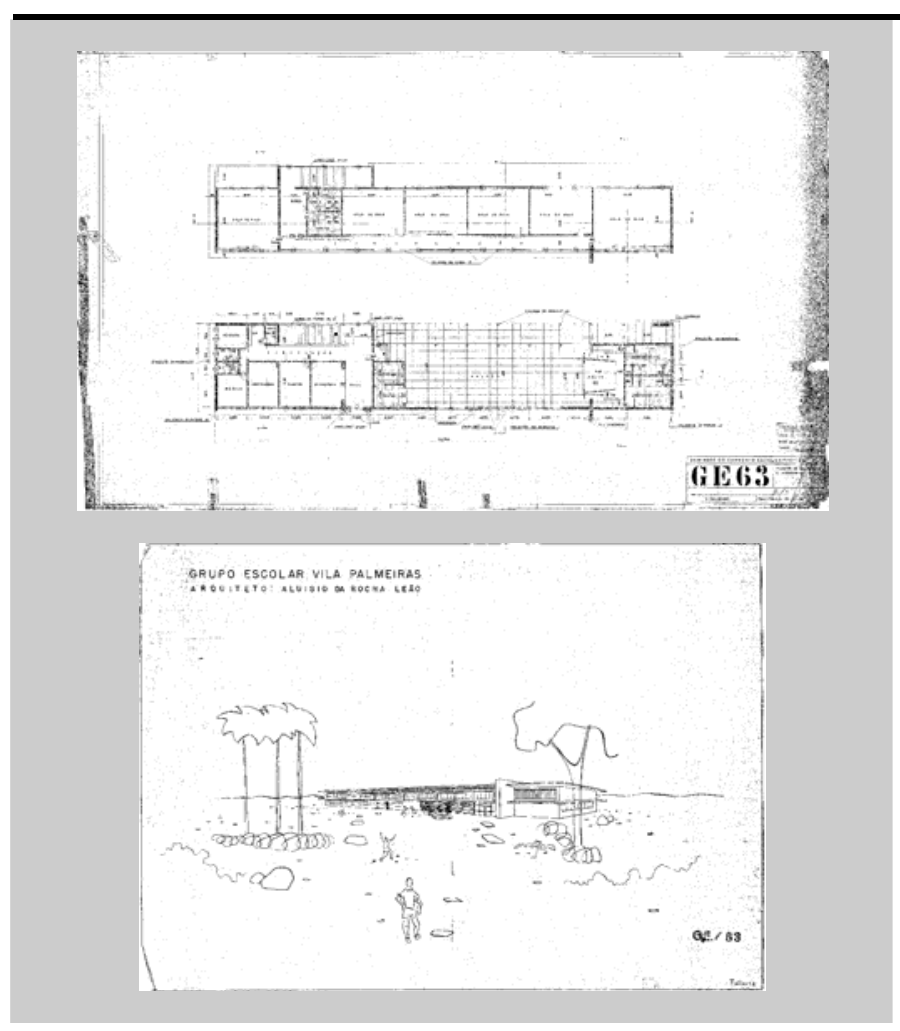

O autor é Aluísio Rocha Leão, e a data é 1952. Outro projeto compacto. A composição aditiva não se aplica aqui. A volumetria unitária se impõe sobre os usos internos. Em outros projetos também compactos isso não ocorre. 
Vila Sônia (G. E. 64)
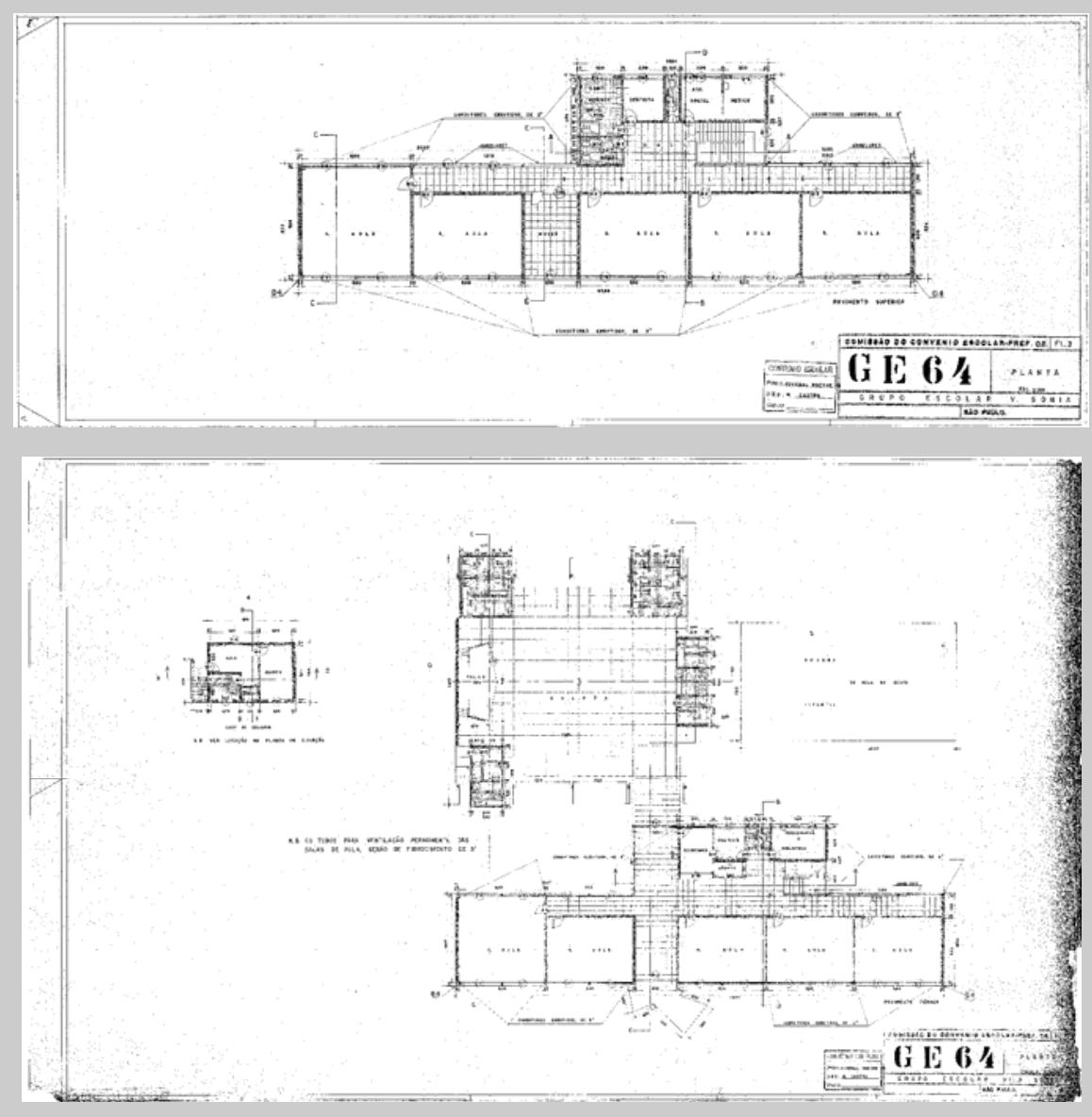

Sem data. O autor é Juvenal Waetge Jr.

Perus (G. E. 65)

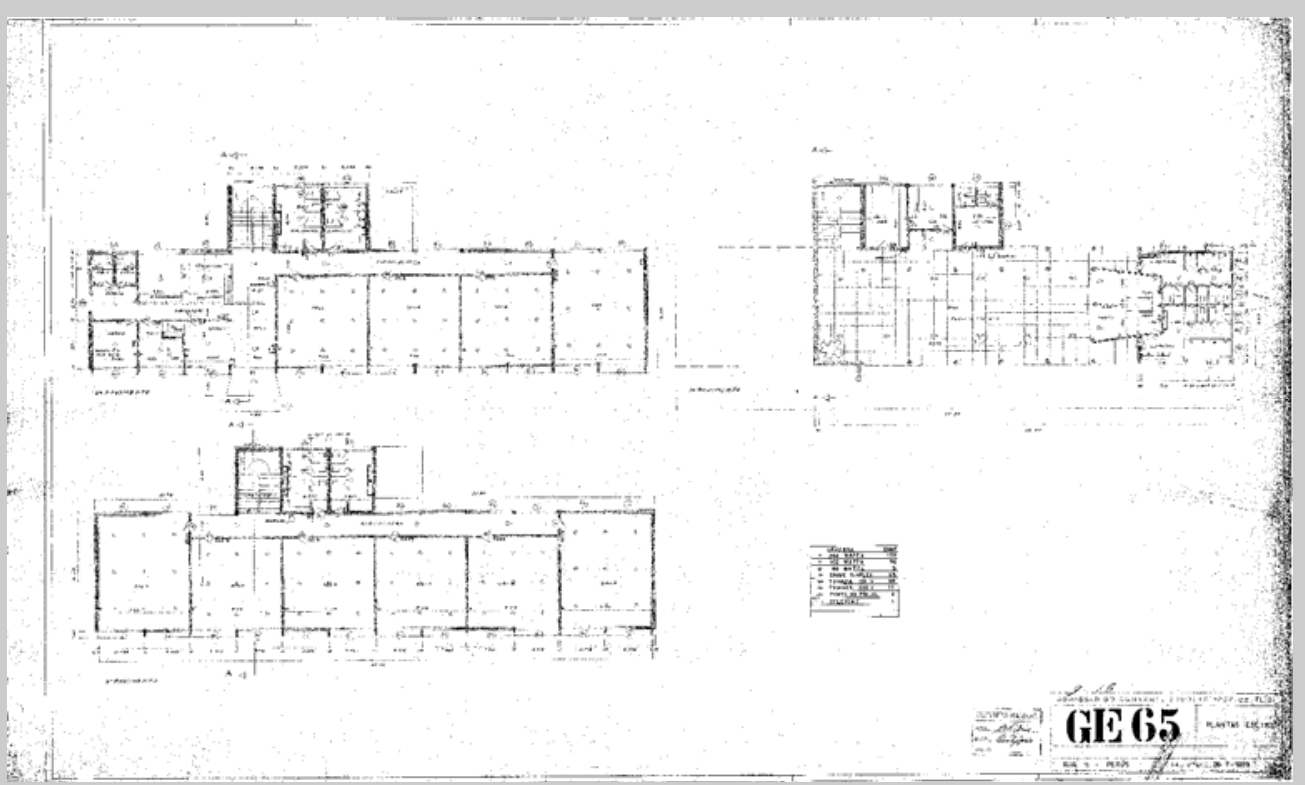

A data é de 26 de janeiro de 1953, de Roberto Tibau. O autor foi responsável pela realização da maioria dos projetos mais compactos de escolas. 
Arnaldo Barreto (G. E. 66)

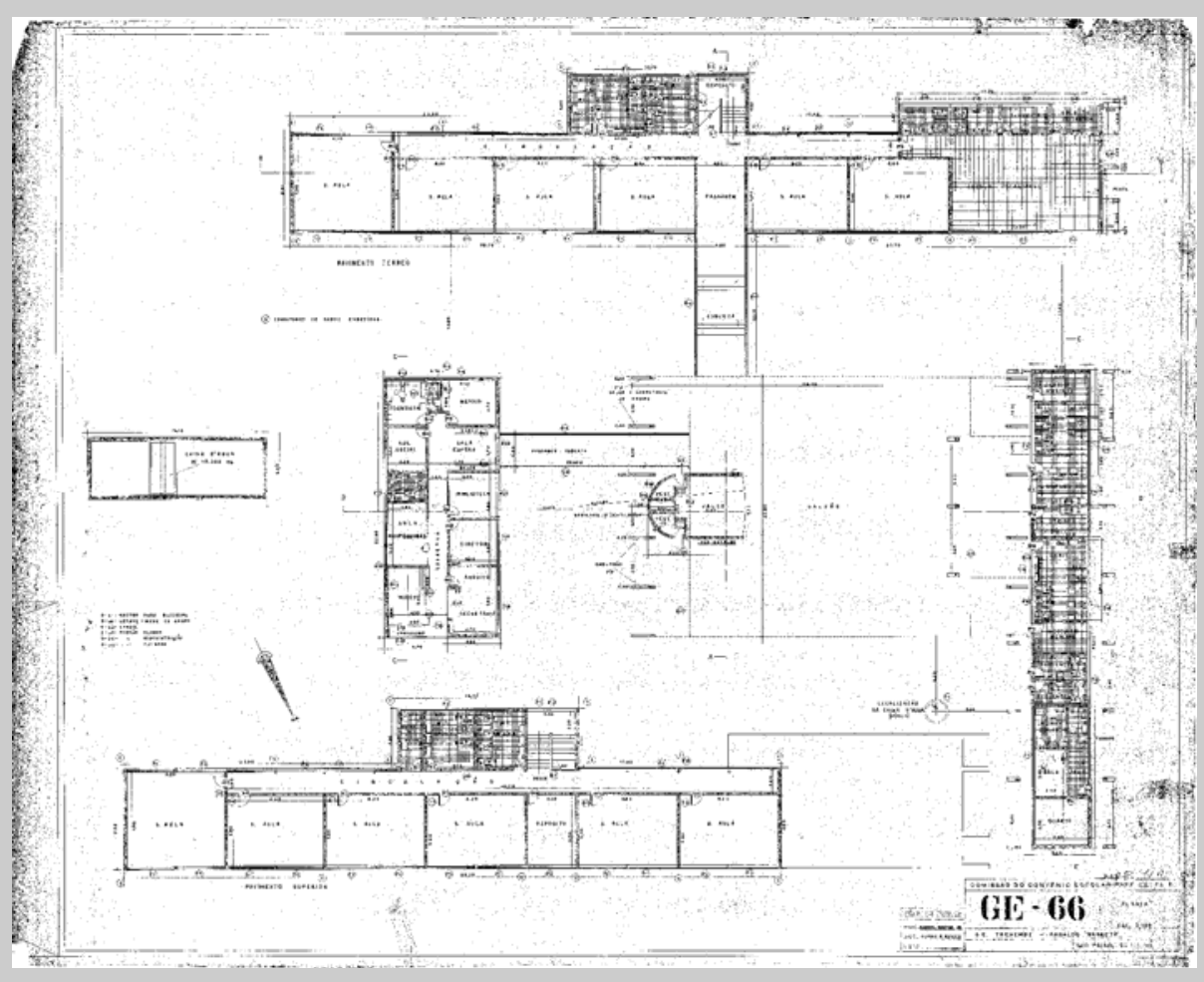

Datado de 25 de fevereiro de 1953. O autor é Juvenal Waetge Jr. A composição aditiva permitia uma grande velocidade na fatura dos projetos, uma vez que os ambientes já estavam previamente definidos. Waetge foi um dos mais produtivos arquitetos da época.

Alberto Torres (G. E. 67)

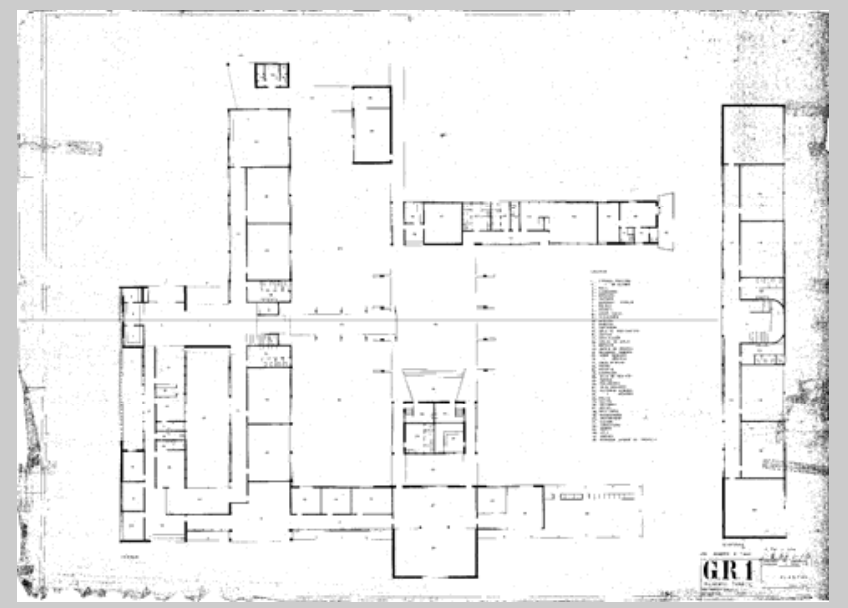

Esta escola, apesar de ter a indicação de grupo escolar é um grupo rural (G. R. 1), com data de 16 de novembro de 1951. O autor é Roberto Tibau, com modificações feitas em 27 de junho de 1952. O projeto incluiu habitações para estagiárias (desenho inferior).

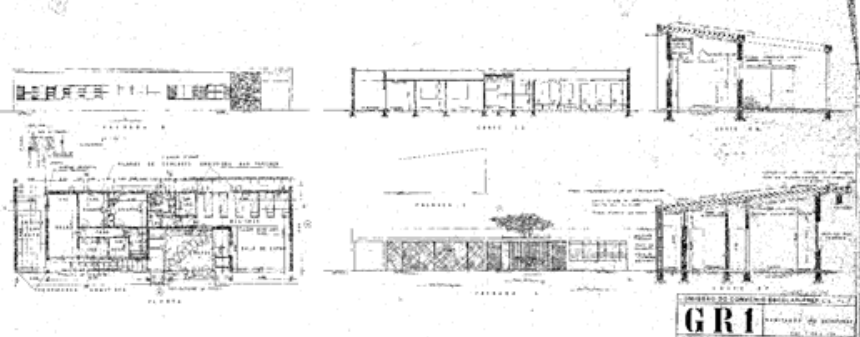


Coronel Domingos Ferreira (G. E. 68)

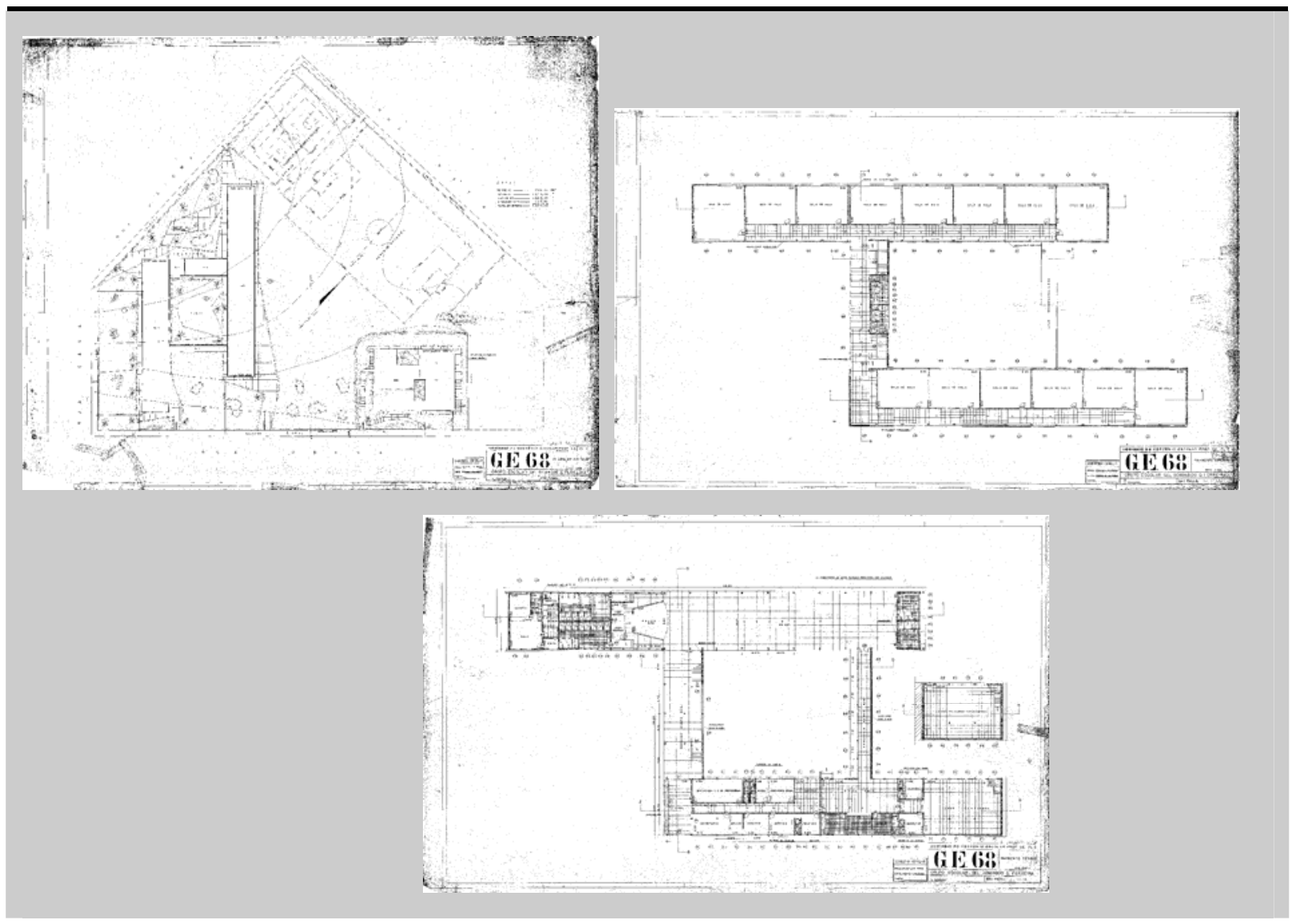

Data de 20 de agosto de 1953, por Paulo Rosa. Situação rara pode ser encontrada neste projeto: o pátio central aparece, ainda que delimitado em dois lados apenas por circulações abertas.

Pedreira do Rio Grande (G. E. 69)

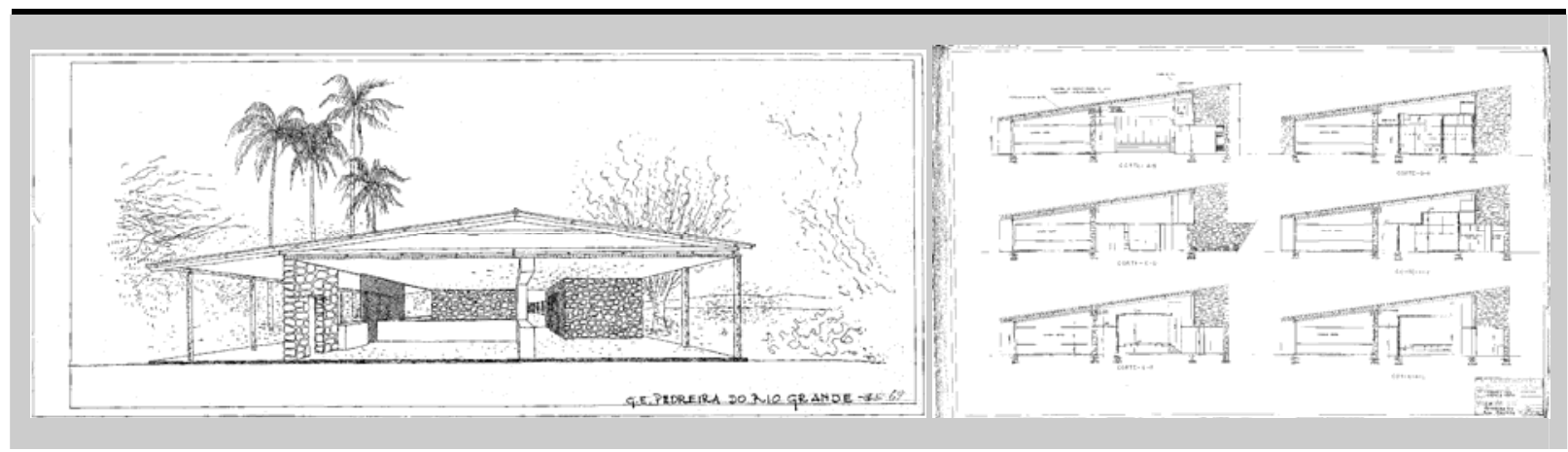

Este projeto distancia-se bastante das soluções formais encontradas nos demais projetos da CE. O projeto é de 1957, apesar de a numeração estar situada entre projetos mais antigos, o que pode indicar que se trata de um projeto que tenha sido muito modificado. $\mathrm{O}$ autor é Roberto Tibau. O sistema construtivo, baseado em paredes autoportantes de pedra, também é incomum e só foi identificado neste projeto. 
Campo Belo (G. E. 71)

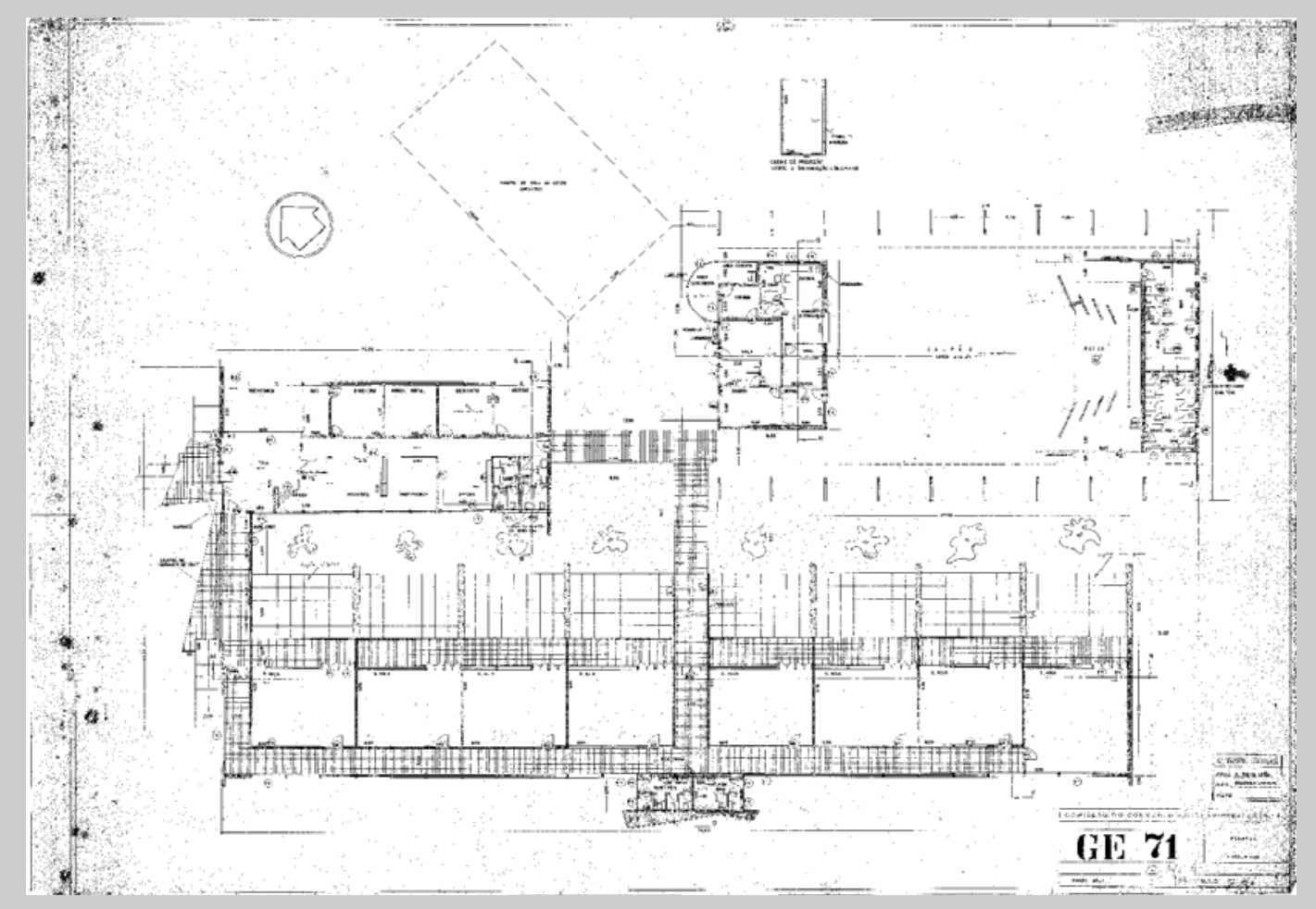

O autor é Aluísio Rocha Leão, sem data identificada. A fachada sul é constantemente evitada para as as salas de aula

Paulo Eiró (G. E. 72)

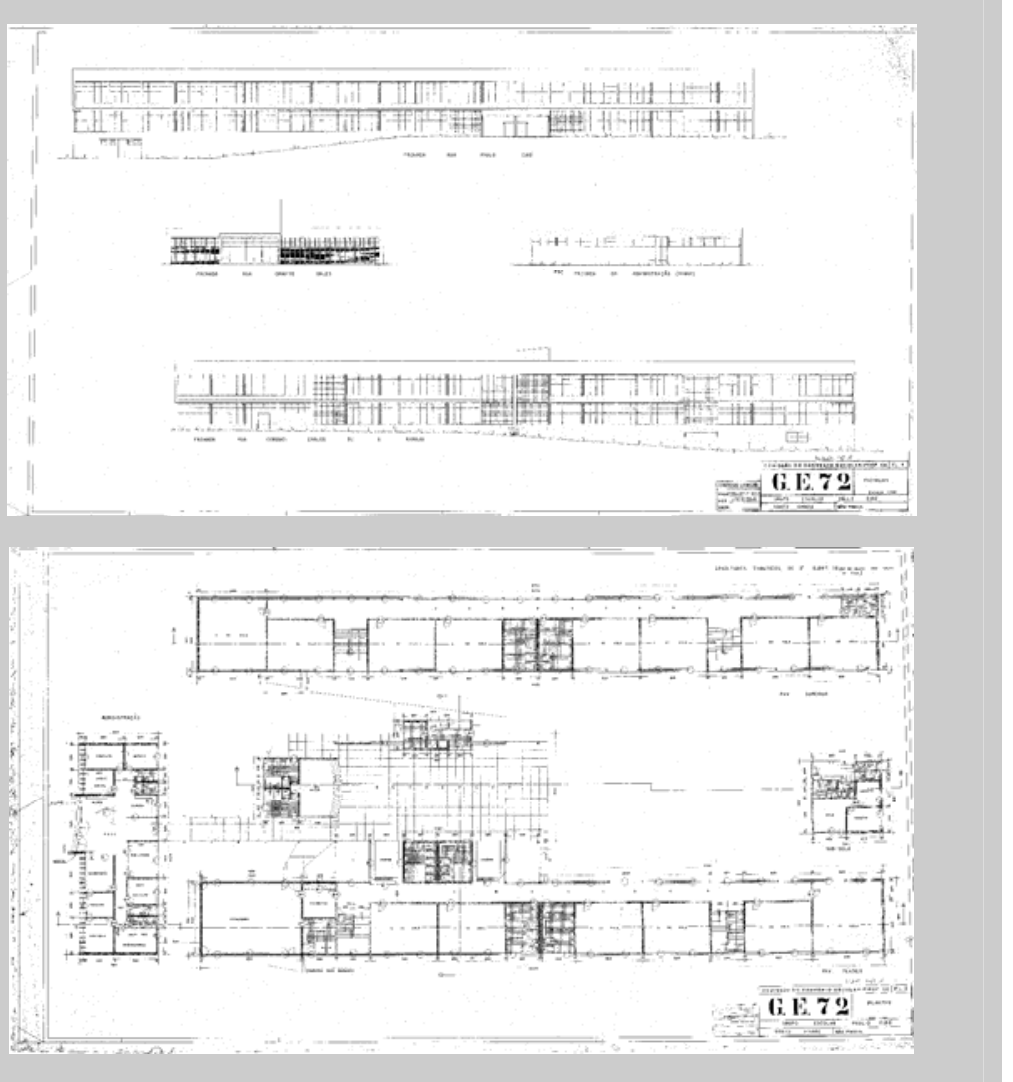

O projeto não tem data gravada, e as reformas foram feitas por Roberto Tibau e Juvenal Waetge Jr. Já havia ali um grupo escolar, cuja edificação foi medida e catalogada em 1948. 
Mirandópolis (G. E. 73)
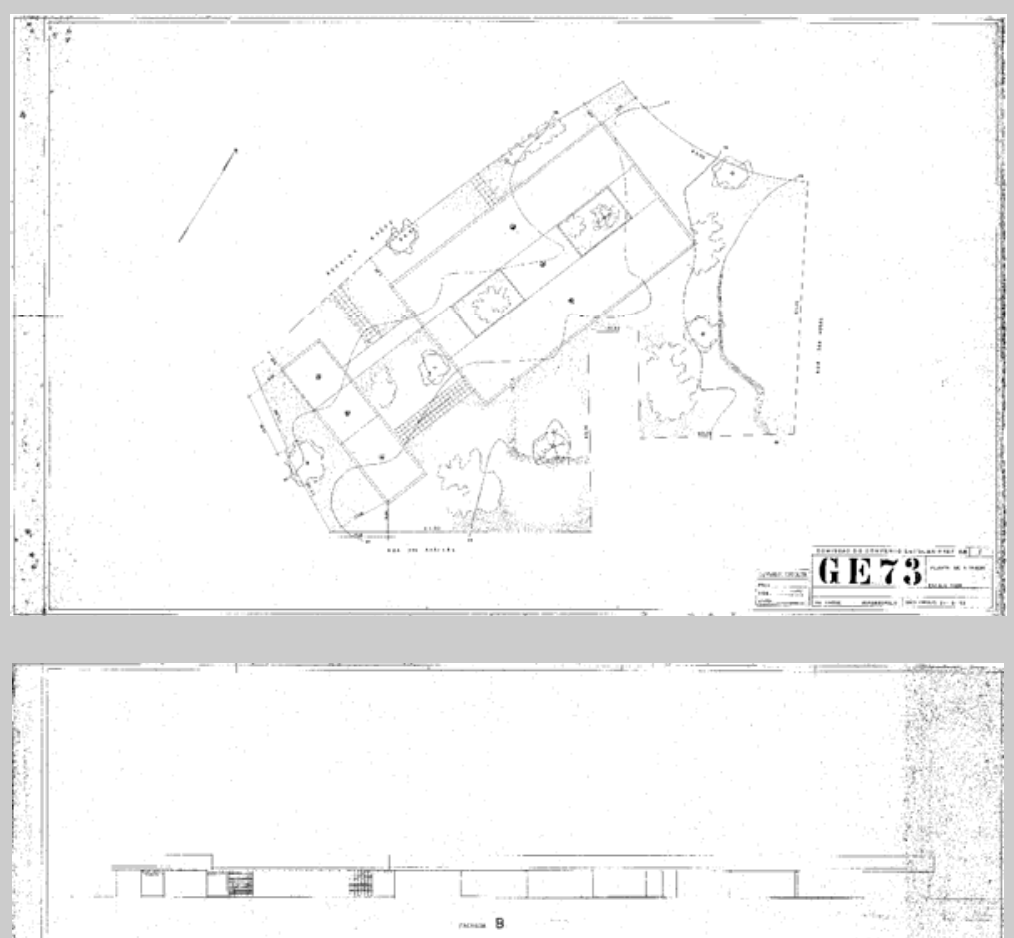

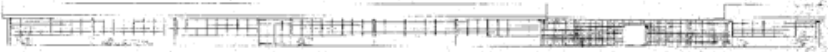
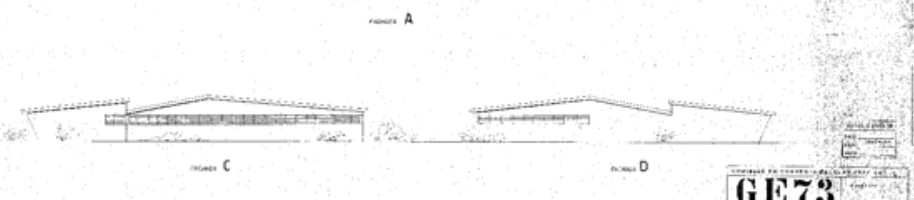

GE78

O desenho está datado de 21 de setembro de 1953. Os aspectos mais diferentes deste projeto são a cobertura e a criação de dois pátios internos.

Vila Cristianópolis (G. E. 74)

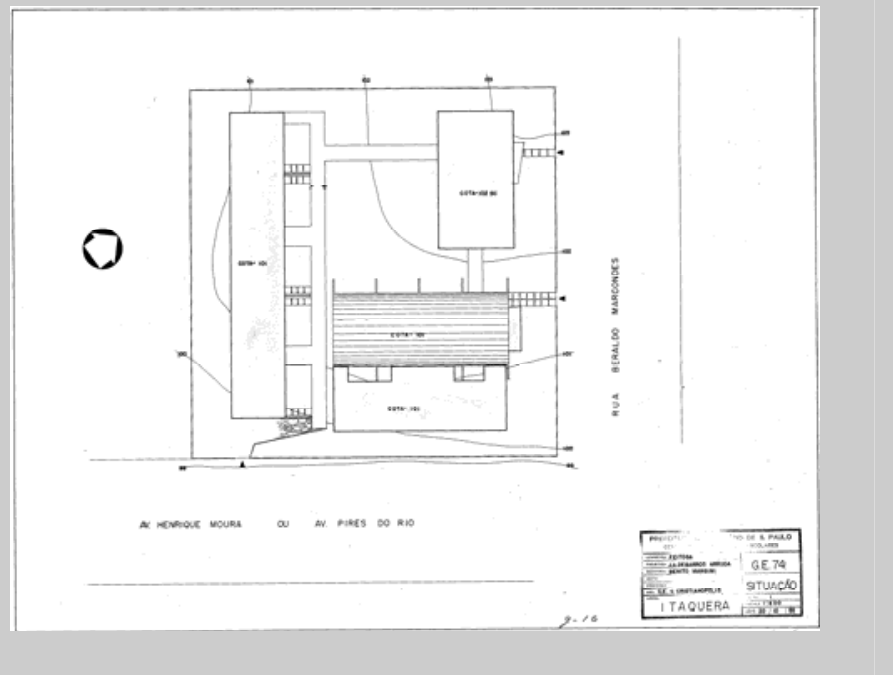

Datado de 20 de outubro de 1955, por

José Arruda, procura evitar os extensos corredores que levam às salas de aula. 
Vila Ema (G. E. 79)
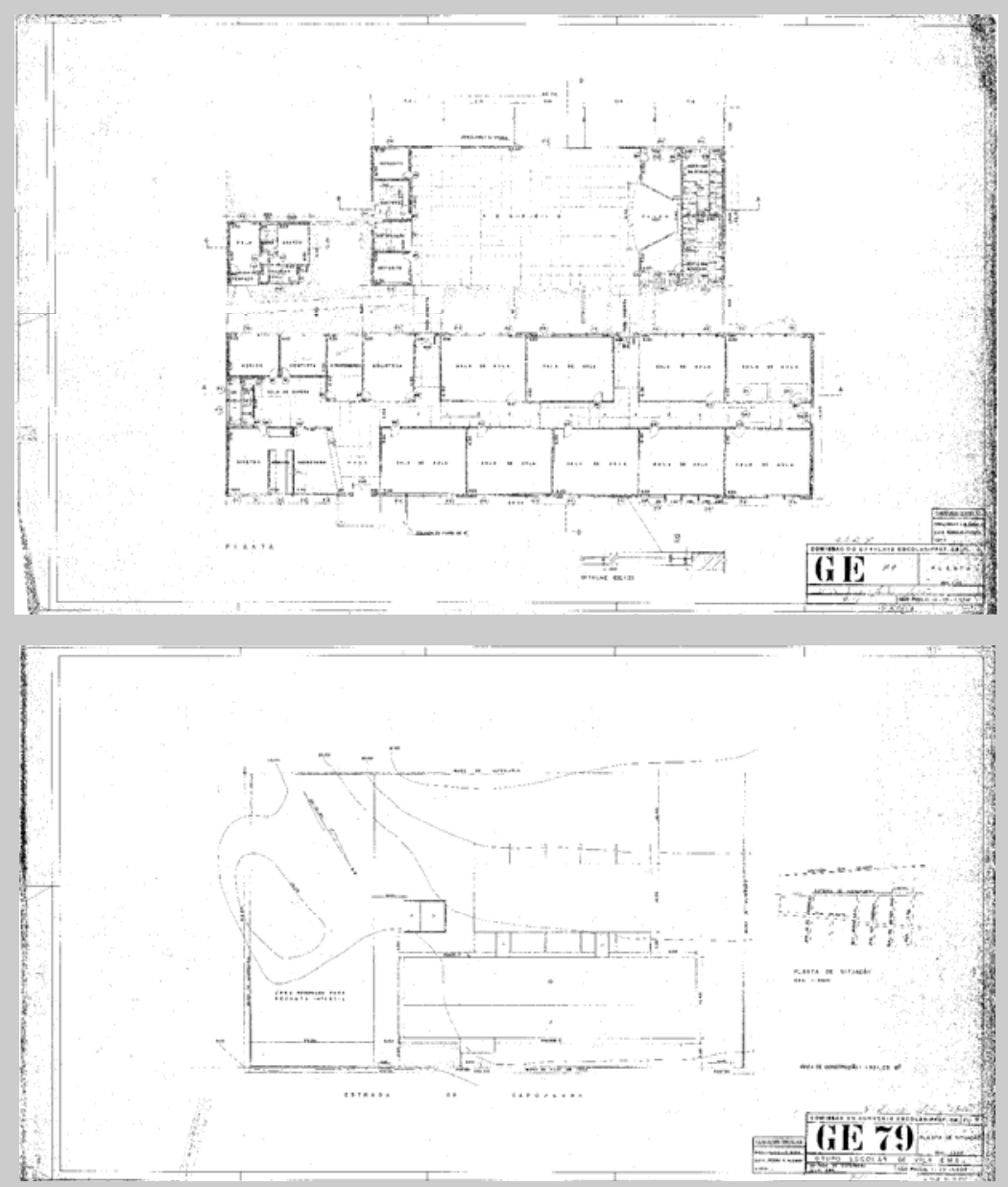

Datado de 14 de outubo de 1954, por Paulo Rosa. Em um projeto incomum, o autor adota salas de aula de ambos os lados da circulação central.

Jardim São Paulo (G. E. 81)

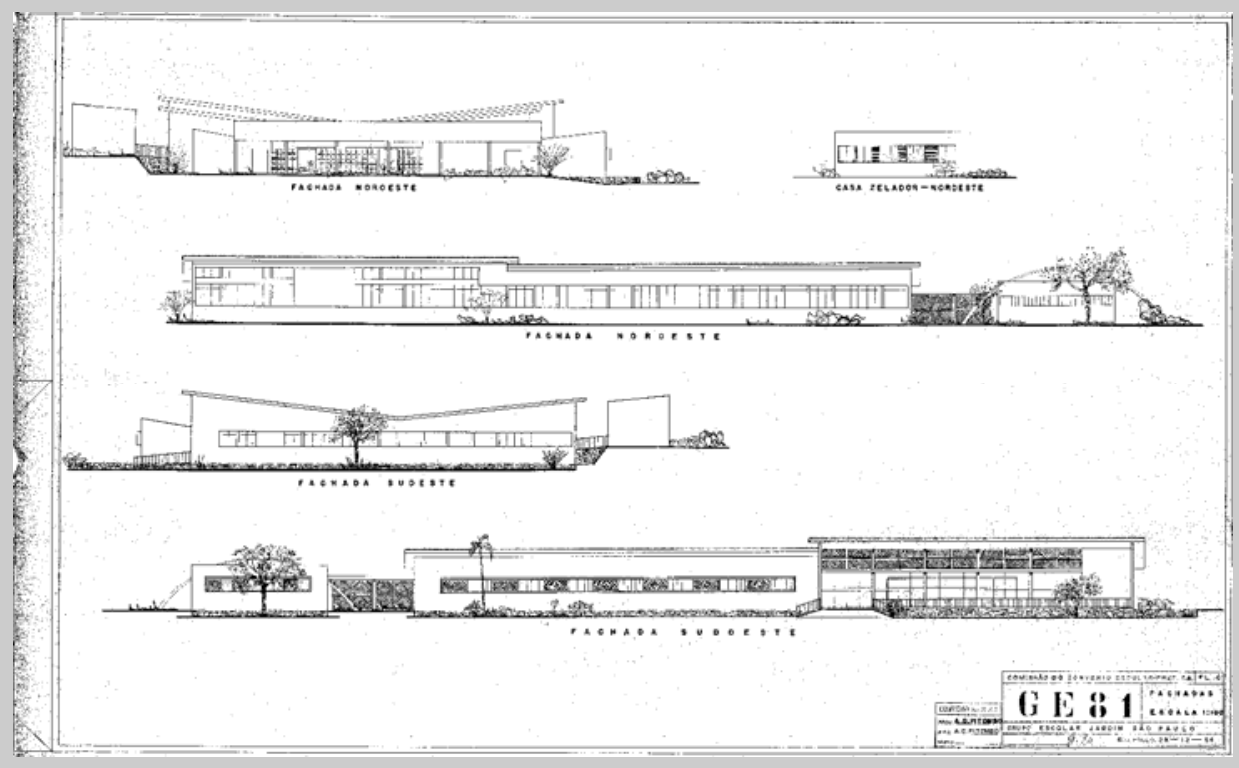

Datado de 21 de dezembro de 1954. Autoria de Antonio Pitombo. 
Raul Fonseca (G. E. 84)

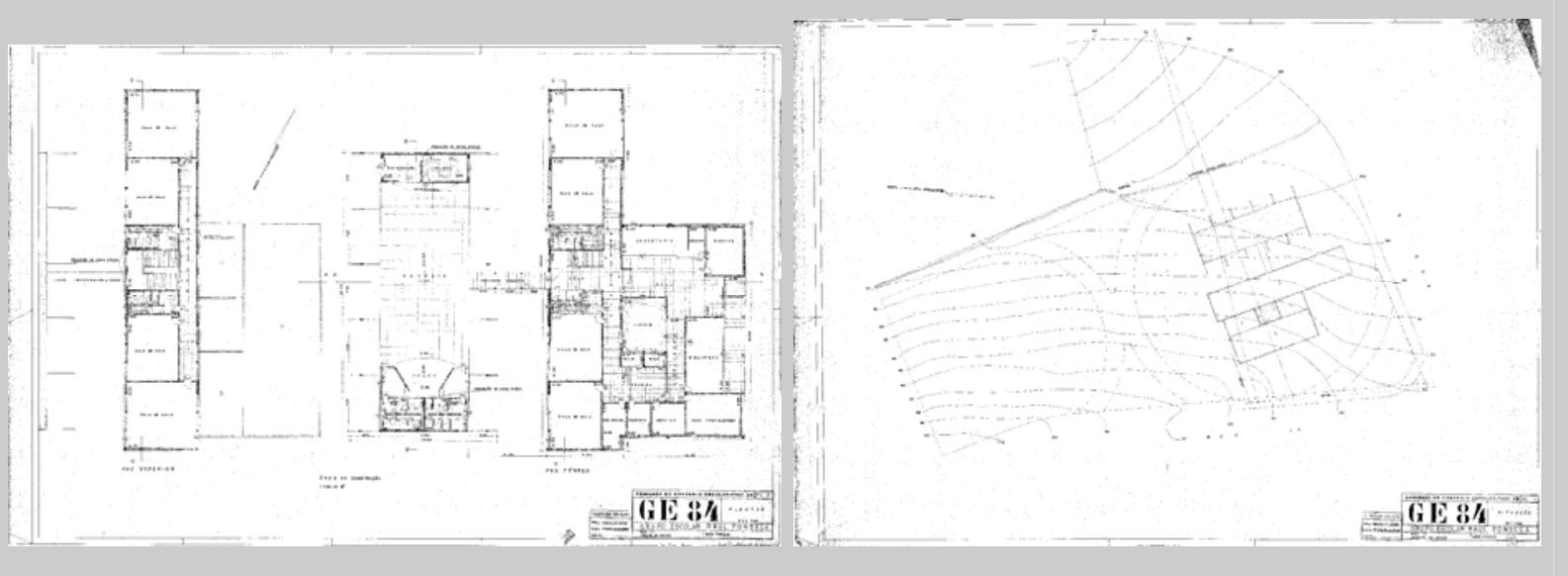

Sem data identificada. Projeto de autoria de Paulo Rosa.

Frederico Steidel (G. E. 87)
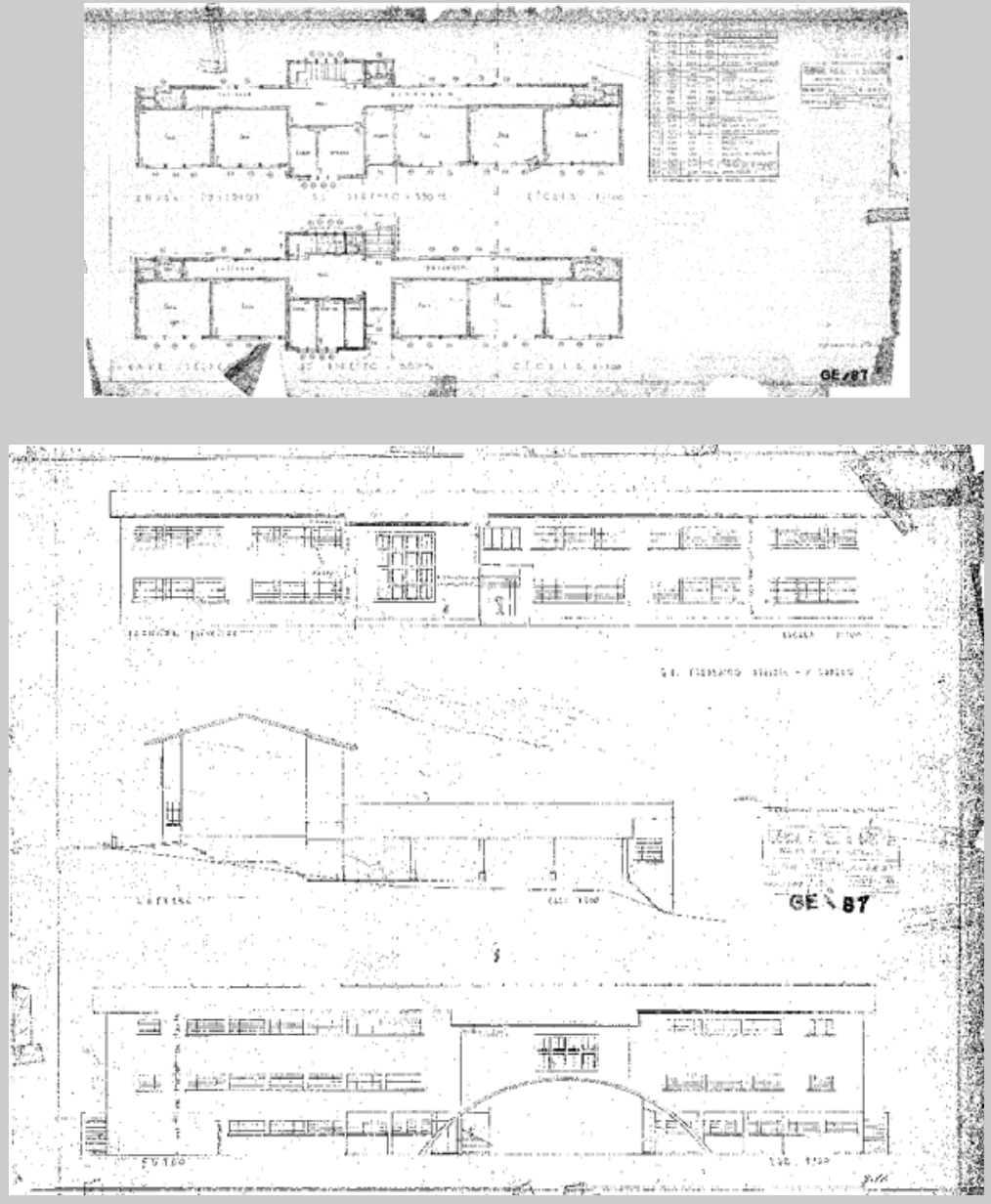

A planta de locação e demais desenhos são de 1949, e é o único projeto em que o autor identificado nas folhas não é um dos arquitetos participantes da CE. A autoria é de Ferreira Fanuele e Barreto Engenheiros Arquitetos. O projeto revela uma falta de unidade plástica e equilíbrio dos volumes. 
Jardim Penha (G. E. 89)

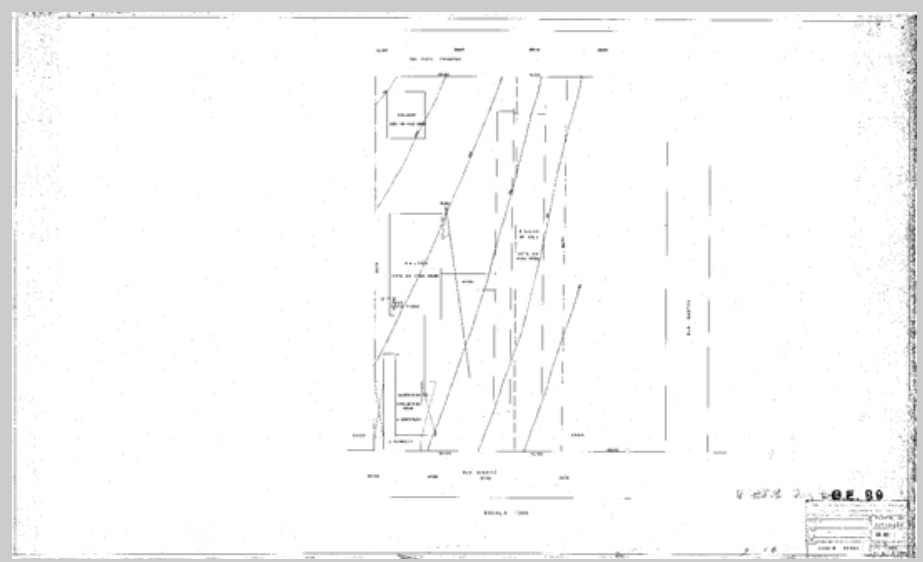

Datado de 3 de abril de 1956, o projeto tem 8 salas de aula.

José Escobar (G. E. 91)

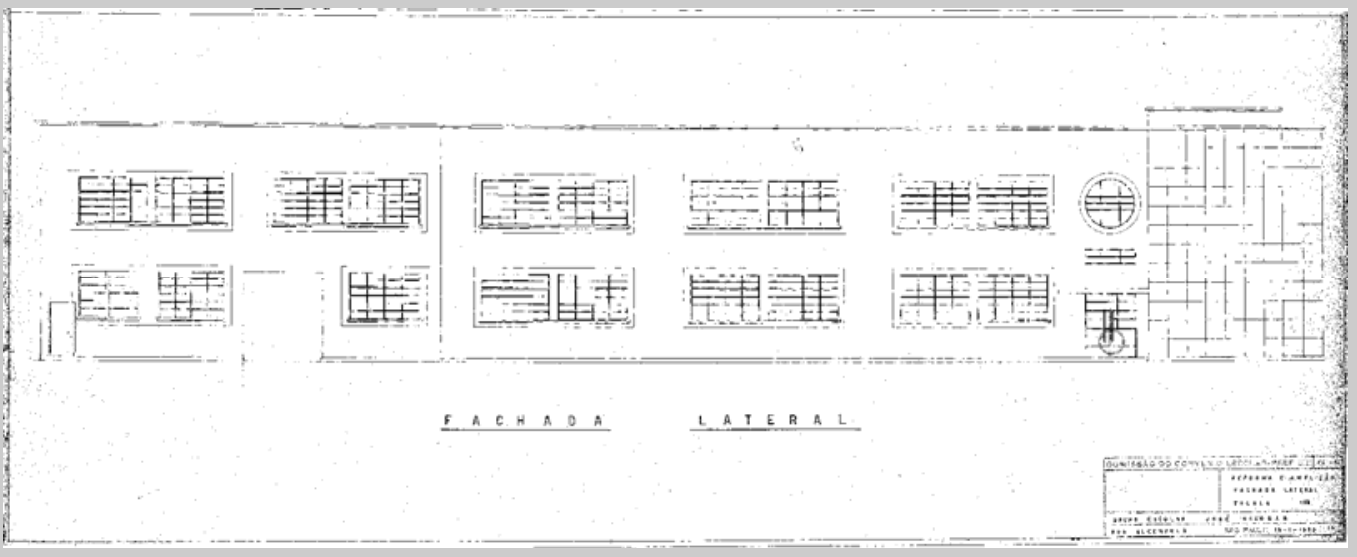

O projeto sobre o qual foi feita a reforma tem características Art Deco e o autor da mesma tenta manter a mesma linguagem. A data da reforma é de 16 de janeiro de 1953.

Antônio Firmino Proença (G. E. 98)
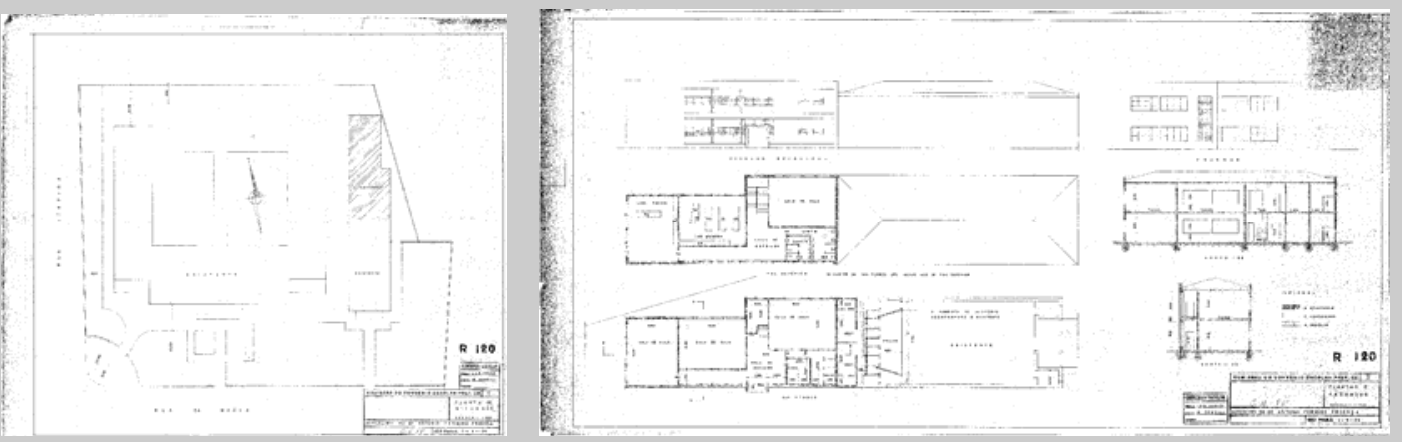

A reforma com acréscimo é da autoria de José Arruda, em 1954. Ao contrário do G. E. 91, as linguagens são bastante distintas. 
Piqueri (G. E. 99)

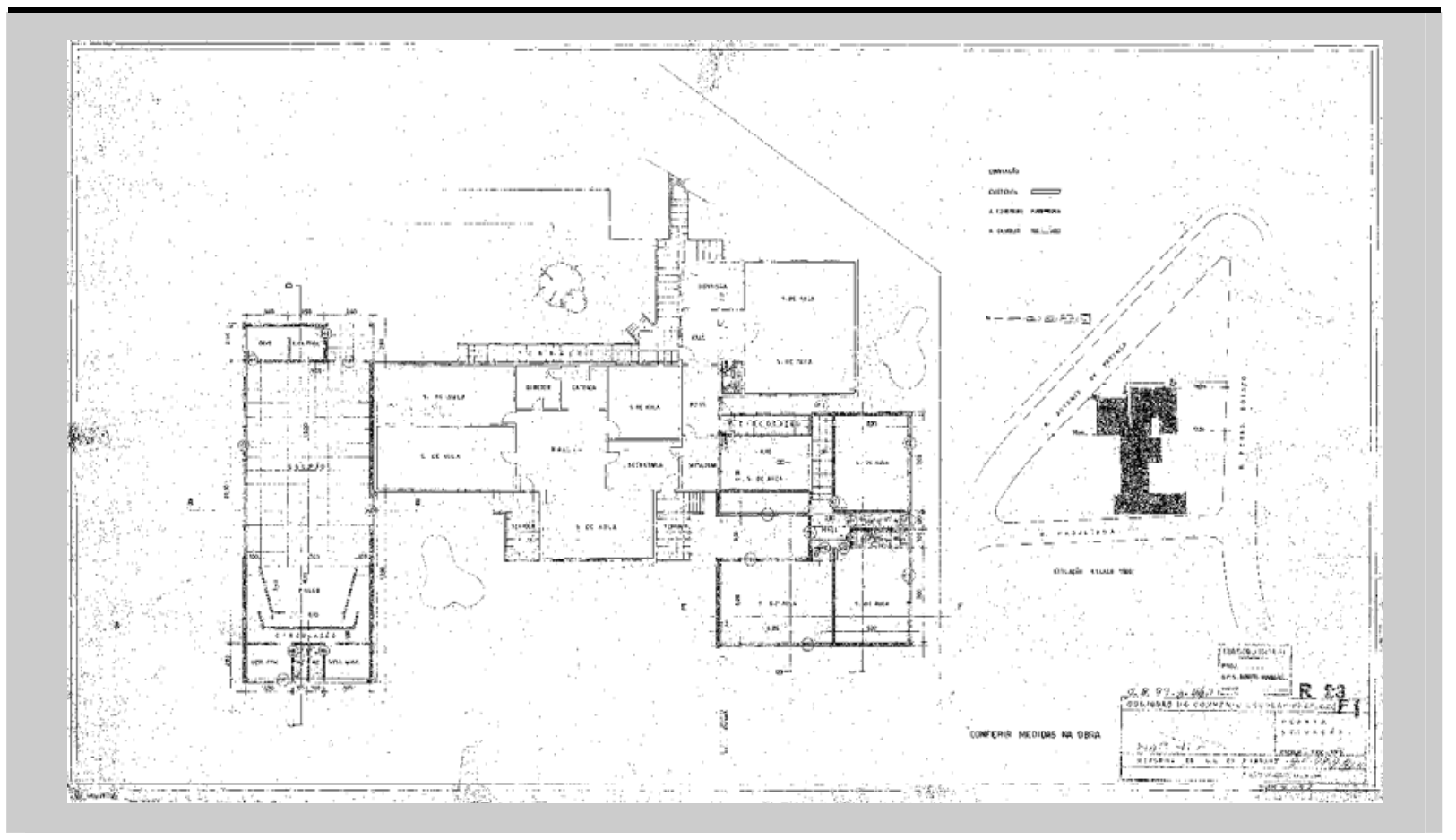

Datado de 13 de maio de 1954. Esta foi a única planta encontrada deste projeto. Há uma organização interna dos espaços que evita a linearidade das plantas feitas até aqui. 